A NATHRALISTI

ON THE PROWL

BM BIIA . . . . . .
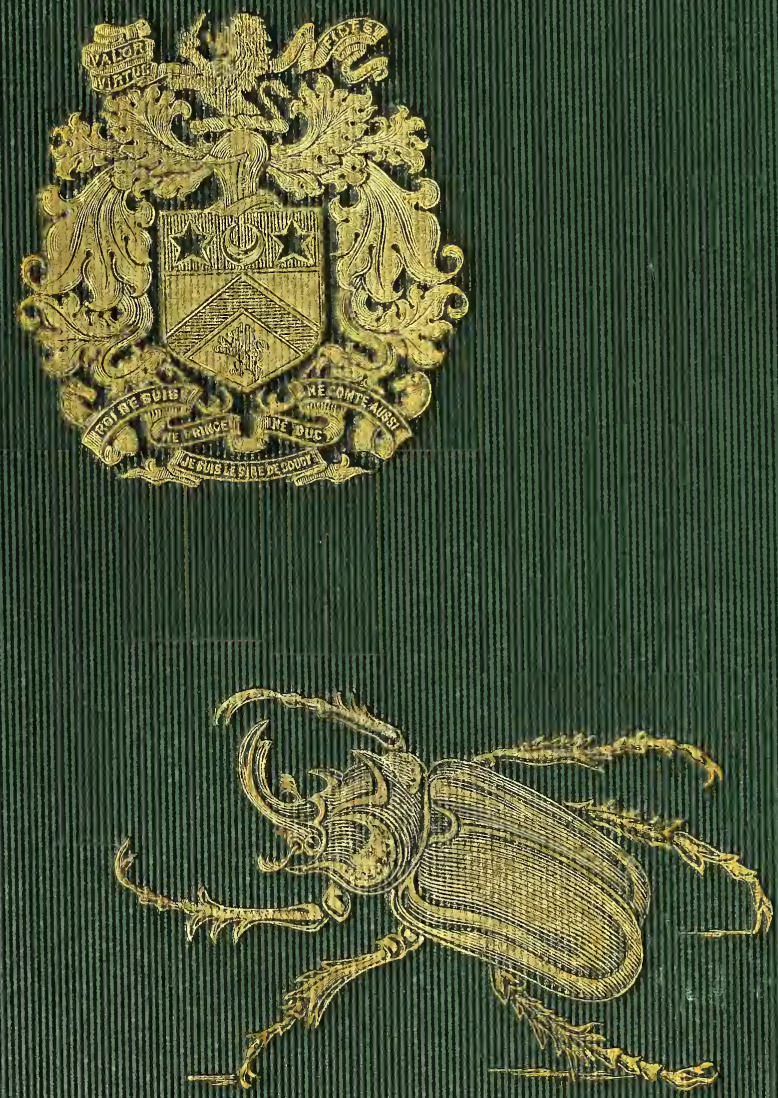


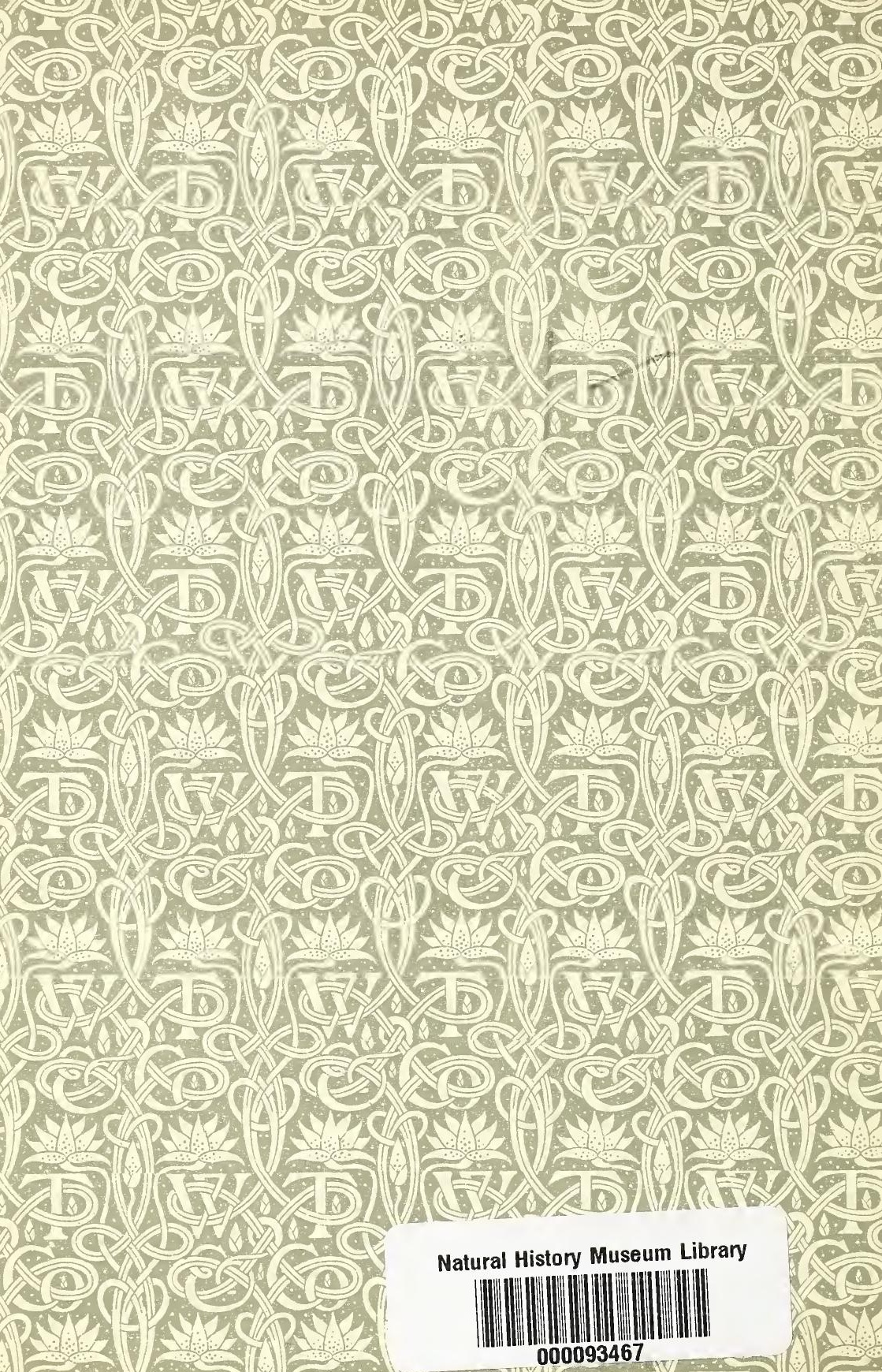



or 
A NATURALIST * *

* * ON THtE PROVNL 


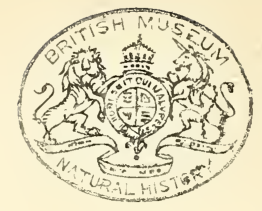

\section{Cbacker's Six=sbilling Series.}

\section{Illustrative of Anglo=Indian Life.}

Crown 8vo., cloth gilt. Piice 6s. each volume.

\section{THE TRIBES ON MY FRONTIER. By}

EнA. An Indian Naturalist's Foreign Policy. With 50 Illustrations by F. C. MACRAE. Sixth Edition.

In this remarkably clever work there are must graphically and humorously described the surroundings of a Mofussil Bungalow.

\section{BEHIND THE BUNGALOW. By EHA.}

With 53 Clever Sketches by the Illustrator of "The Tribes." Eighth Edition.

As "The Tribes on my Frontier" graphically and humorously described the Animal Surroundings of an Indian Bungalow, the present work describes with much pleasantry the Human Officials thereof, with their peculiarities, idiosyncrasies, and, to the European, strange methods of duty.

A NATURALIST ON THE PROWL. By EhA. With 8o Illustrations by R. A. Sterndale, F.Z.S. Third Edition.

In this book the Author deals in his amusing and interesting way with the animals, insects, etc., that are common to India, and it forms to some extent a sequel to "The Tribes on my Frontier."

LAYS OF IND. By Aliph Cheem. Comic and Satirical Poems, descriptive of an Anglo-Indian's Life in India. Illustrated by the Author, LIONEL INGLIS, R. A. Sterndale, and others. Eleventh Edition.

TWENTY-ONE DAYS IN INDIA : Being the Tour of Sir Ali Baba, K.C.B. By George Aberigh-Mackay. With Illustrations. Seventh Edition. 



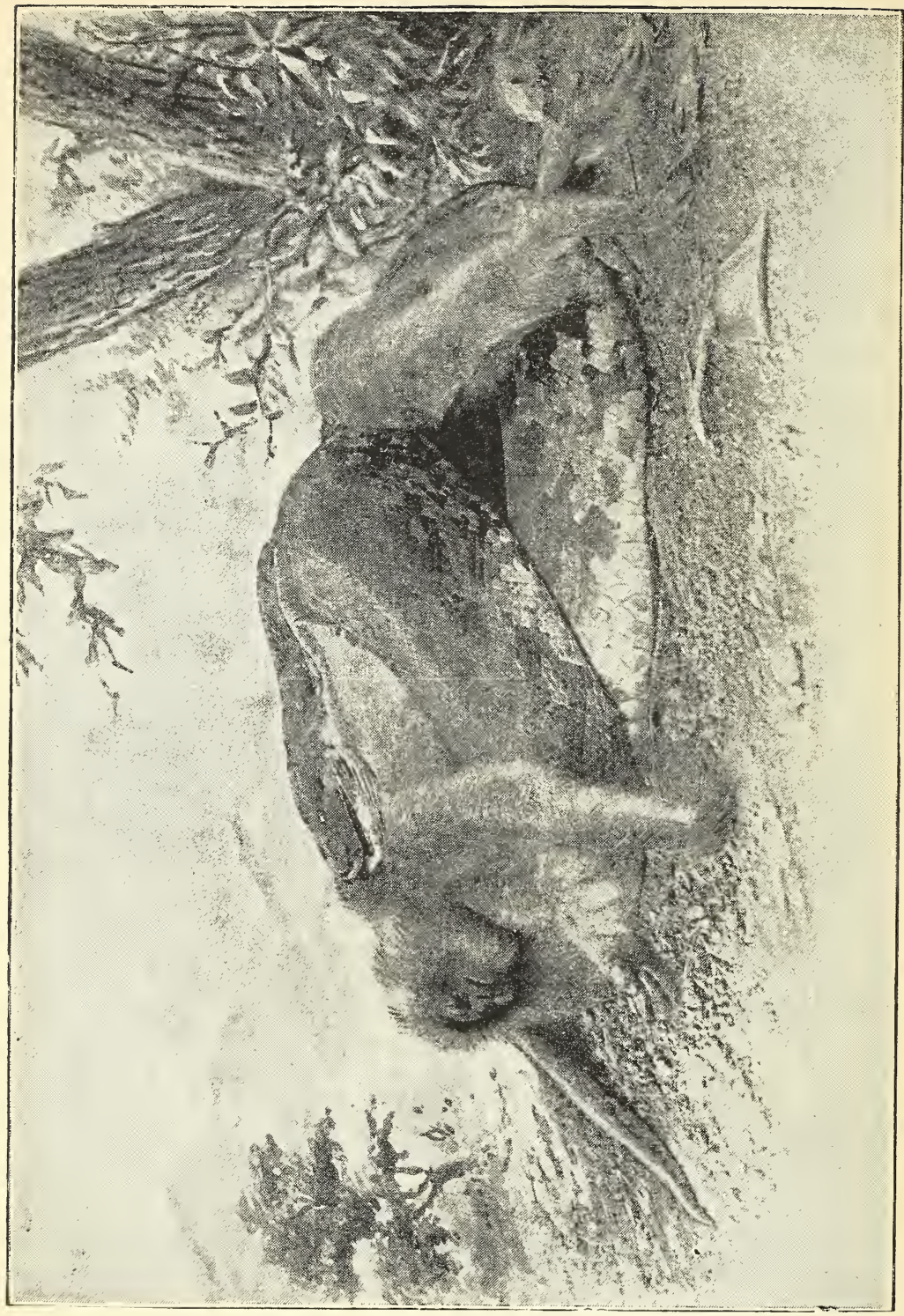


A

NATURALIST ON THE PROWL OR

\title{
IN THE JUNGLE
}

\author{
BY \\ EHA \\ AUTHOR OF "THE TRIBES ON MY FRONTIER" \\ "BEHIND THE BUNGALOW"
}

Ifllustrated by

R. A. STERNDALE, F.R.G.S., F.Z.S.

THIRD EDITION

L O N D O N

IV. 'Thacker \& Co., 2, Creed Lane, E.C. CALCUTTA \& SIMLA: THACKER, SPINK \& CO. I 905

[All rights rescrued] 


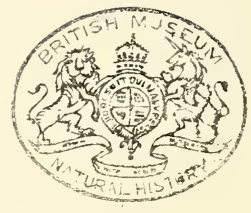

LONDON :

PRINTED BY WILLIAM CLOWES AND SONS, LIMITED, DUKE STREET, STAMFORD STREET, S.E., AND GREAT WINDMILL STREET, W. 


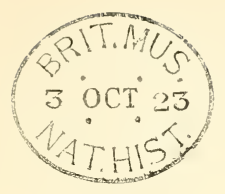 \\ PREFACE.}

FOR their first introduction to the public, these bashful papers are indebted to the Times of India. For courage to re-appear in another dress, they are indebted to "the fascinating beams of a simper," as the biographer of Onoocool Chunder Mookerjee beautifully expresses it, which the Author thought he detected on the kind countenance of that public. For their subject and inspiration, they are indebted to the glorious forests of North Canara on the west coast of India. 


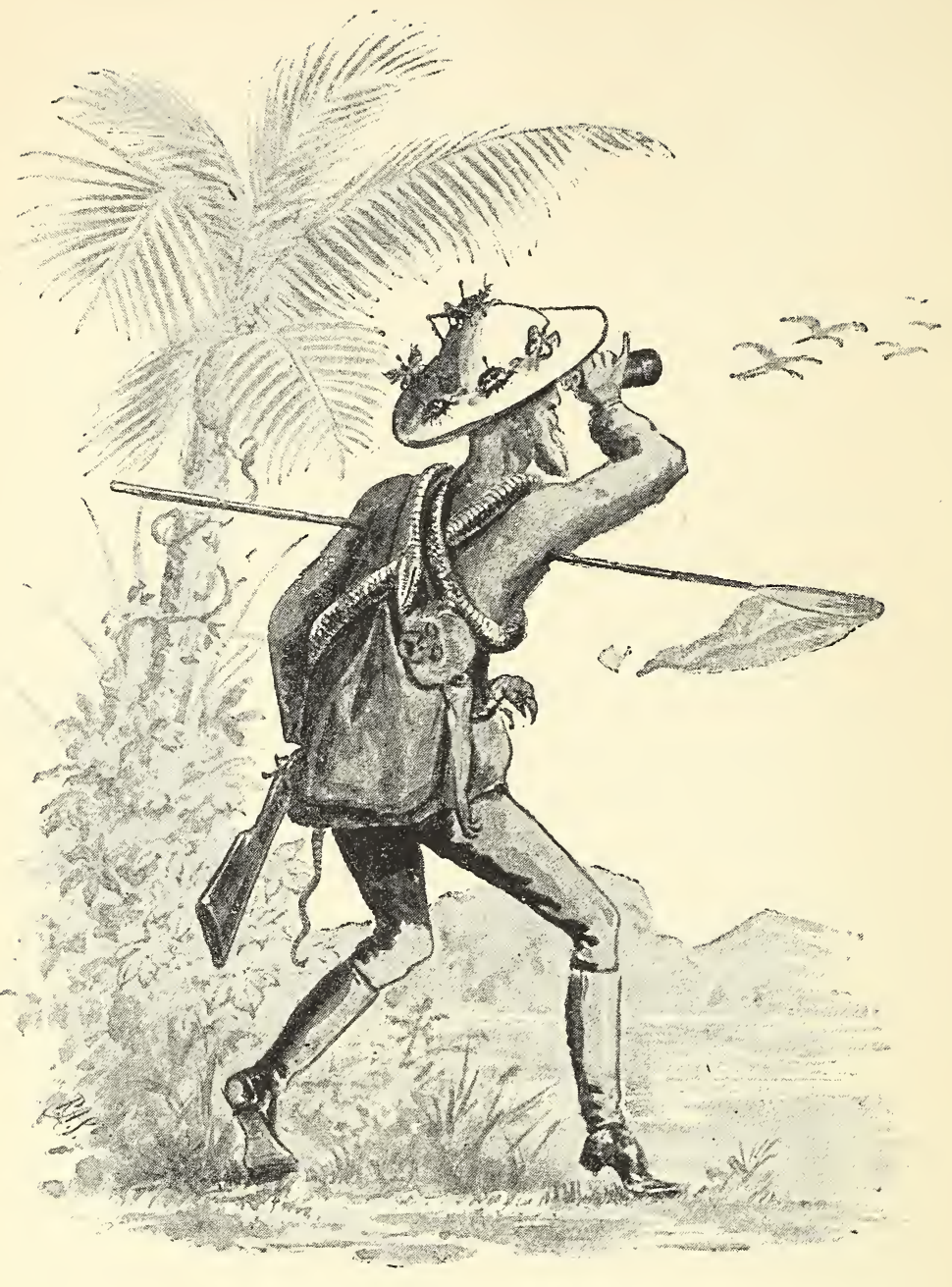

A NATURALIST ON THE PROWL. 


\section{CONTENTS.}

CHAPTER.

I. ON THE PROWL . . . . $\bullet$ I

II. CRABS • . . • . . . II

III. The Voice of Mirth • • • • • 22

IV. The KING Cobra • • • • • • . 31

v. The Banian Tree . • • . • . . 42

vi. Bird-Nesting • • • • • • 56

vit. Jupiter Pluvius • • • • • • 70

viti. Tillers of the Soll . • . • • . 8 $\mathrm{I}$

IX. Fingers ANd Toes • • • • • • 95

X. Adversity • . . . . . . . I06

XI. Caterpillars • • • • • • • • II7

XiI. The Caterpillar Hunter • • • • - I3o

Xili. Peter and his Relations • • • • 143

XIV. Bulbuls • • • • • • • • • • I54

XV. SPIDERS • • • • • • • • • I64

Xvi. A MOUntain TOP • • • • • 176

XVII. The Red ANt • • • • • • 186

XVIII. BASWESHWAR • • , , . • • • 199

Xix. The Green Tree SNake , . . • 210

XX. AN ANTHRopoid • . . . . 217

XXi. Monkeys • . . . . • . 228

XXII. ANOTHER WORLD • . . . . . . . 236

xxili. A Panther Hunt • • . • • . . 245 


\section{LIST OF ILLUSTRATIONS}

I. Python crushing Monkey (Photograph)

2. A Naturalist on the Prowl

3. ON THE PROWL

4. Butterfly (Tail-piece) .

5. Jackal on the Prowl for Crabs

6. Indian Sea Shore

7. Swimming Crab .

8. A Father Crab .

9. The Voice of Mirth

I0. CICADA .

II. Magpie Robin

12. The King Cobra.

13. GREen BARBET

14. King Cobra Devouring Snake

15. The Banian Tree

I6. Peepul Leaf

I7. BANIAN ON River Side

I8. HORNBILL

19. "PharaOH'S LeAN Kine"

20. EAGLE Bird-NESTING .

2I. Shrike, or Butcher Bird .

22. KING CROW .

23. SUN BIRD

24. Crested Swift.

25. RED WOODPECKER

26. BLACK EAGLE

27. "IN THE MONSOON"

28. Mantis and Phasma Stick Insects

29. View in Matheran

30. BeEtles

3I. Burrowing Beetle

32. Bear attacking ANt-hill .

33. MUNGOOSE

34. LEMUR AND VANDELEURA

35. A Gleeful Little Demon.

36. The beLOVEd Hat

37. Hard Times-Herons .
PAGE

Frontispiece

Facing Contents

I

9

I0

I I

19

21

22

27

30

$3 I$

$3^{6}$

$4 I$

42

49

52

54

55

56

59

60

$6 \mathrm{I}$

63

67

69

70

75

80

8 I

83

91

94

95

100

105

106 
38. Sea Gulls on the Clyde • • • • • •

39. Brahmini Bull • • • • • • • • • I16

40. Caterpillars : Studying Them • • • . • $~$ II7

4I. Ichneumon Fly • • • • • • • • • I25

42. Caterpillars: Hunting them • . . . . $~ 130$

43. "PIGS" • • . • • • • . • • I 35

44. "Order Primates" . . . . . . . . . . I4I

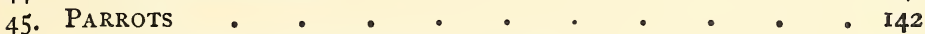

46. TOMmy AtKins and Barrack Parrot . . . . I48

47. Rose-headed Parrakeer . . . . . . . I49

48. Love Bird sleeping • . • . . . . . 152

49. The BIRd MAN • . . . . . . . . I53

50. Bulbuls • • • • • • • • • • •

51. Skull of Bulbul . . . . . . . . .163

52. SPIDER . • • • • • • • • . •

53. "Just Glowrin' frae Him", . . . . . . I7I

54. SPIDER WEb. • . • • • • • • • I75

55. Mountain Scenery (Photograph). . . . . . . I76

56. The Mountain Top . . . . . . . . I77

57. University Clock Tower, Bombay . • . • $\quad$ I82

58. ButTERFly (Tail-piece) • . . . . . . . I85

59. RED ANTS . . . . . . . . . . I86

6o. Red Ants House Building . . . . . . I92

6. A Duello . . . . . . . . . . . I96

62. A JUNGLe • • • . . . . . . . . I98

63. BASWESHWAR . . . . . . . . . . 199

64. Poon Tree. . . . . . . . . . . 204

65. The Guardian of the Silrine . . . . . . 209

66. Green Tree SnAKe . . . . . . . . 210

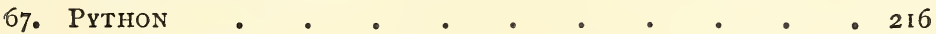

68. AN ANTHROPOID . . . . . . . . . . 217

69. ANTHRopoid at HoMe. . . . . . . 2 I9

70. THE KoITA • . . . . . . . . . 220

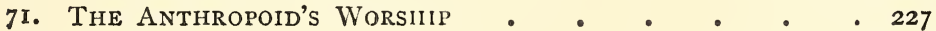

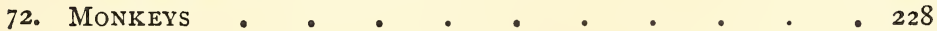

73. LUNGOOR . $\quad . \quad$. $\quad . \quad . \quad . \quad . \quad 233$

74. Bullock Dove • • . . . • . . . 235

75. Vulture and Porpoise . . • • . . . 237

76. Panther Hunt • . . . . . . . . 244

77. Panther on the Watch . . . . . $~ 245$

78. A Trophy . . . . . . . . . . 257 



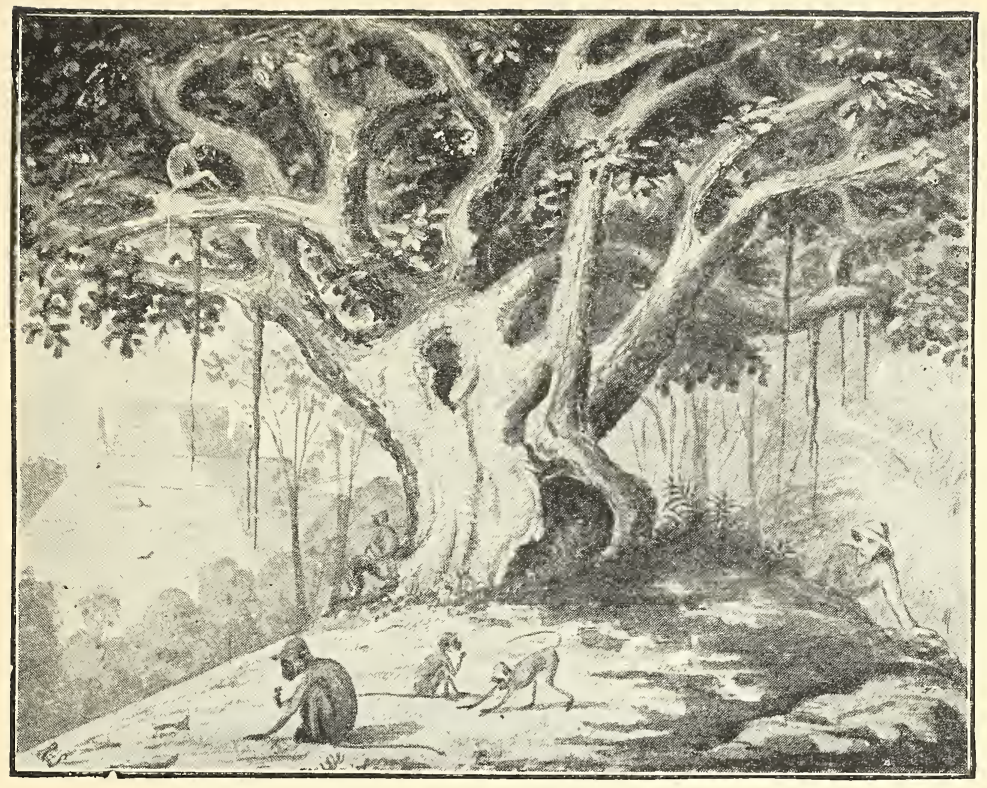

Chapter I.

\section{ON THE PROWL.}

I HAVE always felt a strange pleasure in seeing without being seen. Even when I was an indolent little man of six it gave me rare delight to hide under a sofa and peep at the feet of everybody who passed through the room. "Ha! he does not know that I am here," I said to myself, and "chortled." I cannot quite satisfactorily analyse this kind of enjoyment and am not sure it is very respectabe, but it 
is very human. Stolen waters are sweet, and bread eaten in secret is pleasant.

I have long since given up the pastime of prying into the secret ways of my kind, and to crawl under furniture would now be irksome to me; but I wander into the jungle, where "things that own not man's dominion dwell," and there I prowl, climb into a tree, sit under a bush, or lie on the grass, and watch the ways of my fellow-creatures, seeing but unseen, or, if seen, not regarded; for beasts and birds and creeping things, except when they fear man, ignore him, and so they go about their various occupations, their labours and their amusements, without affectation and without self-consciousness. This is the way to read the book of nature, and after all there is no book like that. It never comes to an end, and there is a growing fascination about it, so that when once you have got well into it, you can scarcely lay it down.

I speak of reading the book. There are many who busy themselves with it and do not read it. There is your doctor of nomenclature, who devotes his laborious life to the elucidation of such questions as whether you shall call the common crow Corvus impudicus or Corvus splendens. $\mathrm{He}$ is an index-maker. Then there is a host of com. 
mentators and editors, who toil to shed such light as they may on the text, or, oftener, on each other. Lastly, there is your collector, who makes extracts. I esteem all these laborious men and feel grateful to them and rejoice that I am none of them, for I hold with Matthew Arnold, that the best use to which you can put a good book is to read and enjoy it. So I take my gun, or net, and go where the leaves are spread. The gun and net I would gladly leave behind, but they cannot altogether be dispensed with. Without a collection a man's knowledge of natural history becomes nebulous and his pursuit of it dilettante. I am sorry it is so, for in spirit I am a Buddhist. But, alas! every Buddhist is not a Buddha :-

"The squirrel leaped

Upon his knee, the timid quail led forth

Her brood between his feet, and blue doves pecked The rice grains from the bowl beside his hand."

They will not treat you and me so, not though we sit as motionless as the horned owl, and repeat the mystic syllable om after the most saintly fashion, in low eruptive snorts : it conciliates nothing but the jungle mosquito and the red ant. For the rest, if you want to know them, you must resort to harsh measures. But do not let yourself get hardened 
Cherish the tender place in your nature which feels a pang when you pick up the little corpse, so happy two minutes ago. And when you have killed enough, stop.

Beware also of the snare which lurks under the intoxicating pleasure of collecting, and set a watch upon yourself, lest you degenerate into a collector and cease to be a naturalist. As soon as you begin to feel that a rare bird or butterfly is not so much a bird or butterfly to you as a "specimen," you have caught the distemper and must take measures to check it. The best remedy I know is to set aside one day in the week for a sabbath of peace and good-will, on which the instruments of death must be laid aside and an amnesty proclaimed to all creation. Then you may move among living things with heart free from guile and mind undistracted by stratagems, and you will note many things in them which you never saw when you were scheming to compass their destruction. You will see how they make their living, what they do when they get up in the morning, and how they pass the day. And you will see deeper into the meaning of their forms and colours than some great men, and will not be afraid to throw away on your own responsibility many postulates and some axioms which are current in the world with the stamp of 
great names upon them. You will also have a chance of learning the profundity of your own ignorance, and to suspect that is to matriculate in natural history.

How abysmally ignorant we are! For years have I been trying to get a conception of how the world presents itself to a butterfly, and as yet I have scarcely got a fact for the sole of my foot. The butterfly has eyes, but what are their powers? It can distinguish light from darkness, for as soon as the sun bursts through a rift in the clouds on a monsoon day, the gay things are on the wing, making the most of their short opportunity. It can also see in our sense up to the length of an ordinary butterfly net, for an extraordinary net is needful if you would catch the wary ones. This seeing must be of a dim sort, however, for, with patience and a steady hand, you may catch a cunning butterfly between your finger and thumb. I suspect a butterfly's eyes are designed primarily for enjoyment of sunlight, and secondarily to give it intimation of any object moving very near to it. Then what about those butterflies that one sees travelling from one island to another in the Bombay Harbour? Do they go to sea in the spirit of Columbus, and is their arrival at Elephanta a happy accident? I cannot tell. Has a 
butterfly ears? No. Can it hear? Yes. If you doubt me, tread on withered leaves, or break a twig. as you are stalking a Funonia. Perhaps the delicate expanse of its thin wings is sensitive to the slightest concussions of the air. Perhaps. This I know, that it is far easier to approach a butterfly on a windy day than when the air is still. Can a butterfly smell? On this point I feel pretty confident, for the flowers they love most are small and inconspicuous. Gaudy convolvuli and gorgeous bellflowers of all sorts address themselves to the gross bumble-bee. But may not a butterfly have other means of knowing than by seeing or smelling? Aye, there's the rub. For what a priori reason is there that the phenomena of this world should reach the brain of a butterfly only through the five gates of Mansoul? And if there are other means of access, how can we even conceive them? What are the antennæ of a butterfly? "Feelers" they are called in English, but to overawe the unlearned, we men of science write of them as antennæ, which means the yards of a ship. Under either term we know as much about them as the butterfly knows why I carry a walking-stick.

Believe me, we are abysmally ignorant. But there is consolation; for when facts do not obstruct, imagination 
grows frisky, and I give her a canter. There is no more exhilarating exercise for the mind, nor any healthier, I believe, so long as she does not take the bit in her teeth and bolt with you.

So I imagine my butterfly to myself in its new-born glory as a being with little mind and almost devoid of thought, but intensely sensitive to a hundred influences of nature which are lost on us, just as an Æolian harp trembles differently to every changing motion of that breeze which the City man scarcely notices unless it blows his hat off. Through the countless facets of those large and shining eyes the splendour of the sun, the greenness of the hills, the blue sky, the hues that glance from its own bright wings, pour floods of undefined, promiscuous joys into the little body; the fragrance of flowers, the stirrings of the air, electric influences perhaps, and the arrows of Cupid, all join to thrill its fragile frame; and the consciousness of abounding vitality and new and strange powers makes response within it, a feeling which is near of kin to pride mingling with its joy. So it dances through the day, full of impressions and impulses, empty of thought or care. Something moving near it casts a shadow on its sight, and it darts 
away without knowing why, startled but not frightened. A rival passes and it dashes at him, powerless to hurt, but bursting with nervous energy which must find an outlet, and the two in mock combat mount up into the sky until they are lost to sight. When it comes down again rest seems sweet, so it sits on a leaf and spreads its wings to the life-giving rays of the sun, or it feels a sensation which we may call thirst, and the fragrance of a flower, answering to that feeling, impels it to unfurl its long tongue and sip those sweets which it never sipped before. At length some sensations of maternity, transitory but urgent, take possession of it, under the influence of which it hovers round a tree, the scent of whose leaves recalls vaguely some former life "that had elsewhere its setting," and to those leaves it feels impelled to commit the burden which it bears. And now the superabounding energy abates, the impulses grow weaker, the thrills of joy become rapidly duller, and without pain or regret it flickers out, like a lamp when the oil is spent.

This is not a "working theory," but only my way of clothing with flesh and blood the dry bones of scanty facts, as geologists restore in pictures the giant forms whose skeletons they have dug out of the bowels of the earth. 
If not for this, then why was the wonderful power of imagination bestowed upon us? Standing in the fossil room of the British Museum, I go back thousands upon thousands of years, and see great swamps and gloomy forests all around me, and hear the Mastodon trumpet as it crashes its way through them. If I could not do this, I would leave the room. If bones are not more than bones, what are they good for? Knife handles.

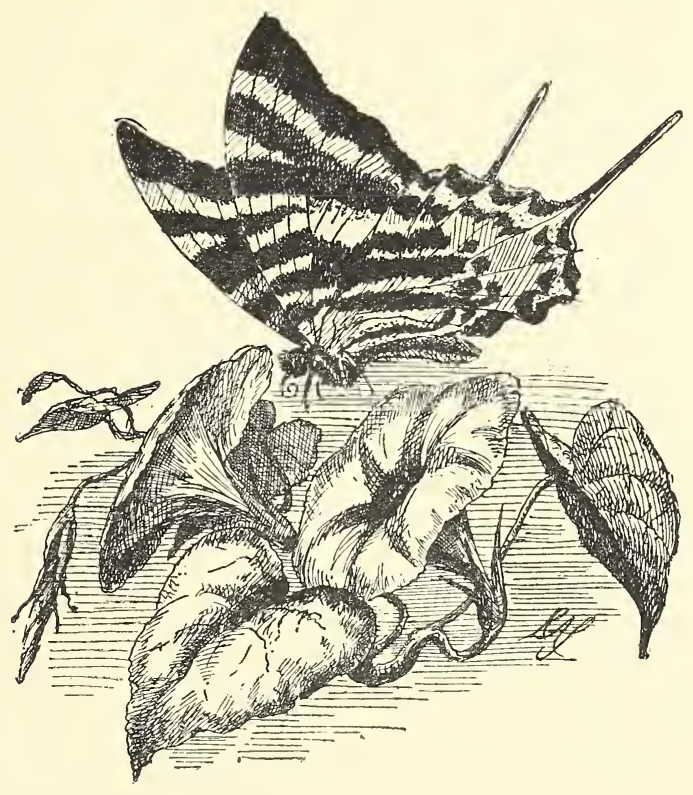




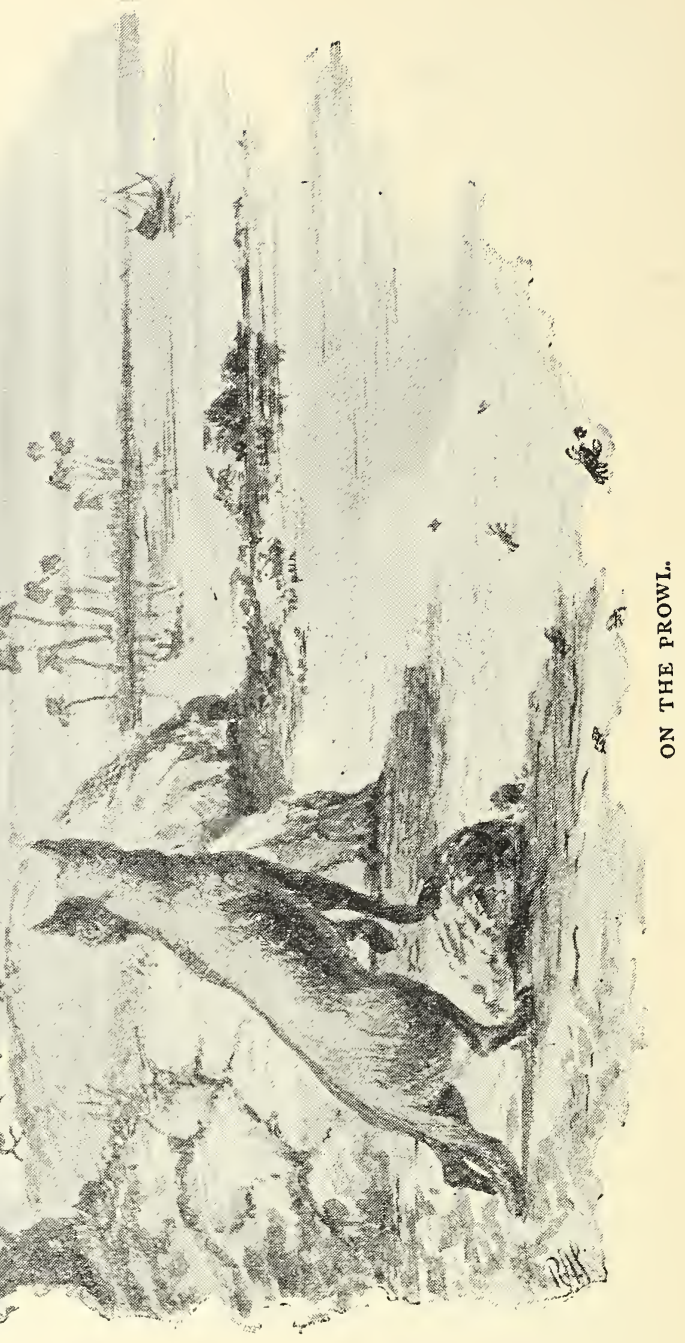




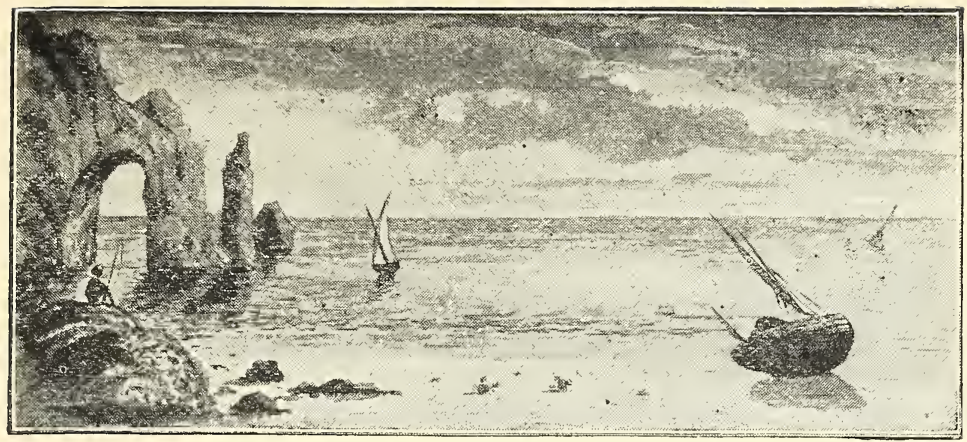

Chapter II.

\section{CRABS.}

PROWLING on the seashore one evening, I espied another prowler, and he espied me, and avoided me as the burglar avoids the policeman. He did not run away, but just deflected his course a little, took advantage of a dip in the sandy beach, got behind a growth of screw pines and was not there. It was getting too dark to see clearly, but by these tactics I knew that he was a jackal. He had come down in the hope of catching a few crabs for his supper. Scarcely had he got himself away when, with a shrill squeak and a scrambling rush, a fat musk rat escaped from my foot into a heap of 
stones. What was it doing there? Hunting for crabs. Now there is something very revolting in the thought that crabs are liable to be killed and eaten by foul jackals and disgusting musk rats. The crabs are a peculiarly interesting people, like the ancient inhabitants of Mexico, unique and not to be ranked with the other tribes of the earth.

Professor Owen holds that the hand of man suffices to separate him from all other animals almost as widely as any two of them differ from each other. "The consequences," he says, "of the liberation of one pair of limbs from all service in station and progression are greater, and involve a superior number and quality of powers, than those resulting from the change of an inguiate into an unguiculate condition of limb." Think me not a mocker if I suggest that the crab shares this endowment with man, and perhaps that is the reason why he seems to stand apart from all other creatures that are clothed with shells. By pedigree the crab, I admit, is but a prawn which has curled its tail under its stomach and taken to walking; but no one who has lived much among crabs and associated with them, so to speak, can lump them with prawns and other shell-fish good for curry. 
A crab is not like a lower animal. He does not seem to work by instinct. All his avocations are carried on as if he had fixed principles, and his whole behaviour is so deliberate and decorous that you feel almost sure, if you could get a proper introduction to him, he would shake hands with you.

At times I have thought I detected a broad grin on the face of an old crab, but this may be fancy. I incline to the idea, however, that he has a sense of humour. $\mathrm{He}$ is courageous too-not foolhardy, but wisely valiant, and marvellously industrious. Watch him as he repairs his house flooded by the tide. Cautiously he appears at the door with a great ball of sand in his arms, and erecting his eyes to see if any enemy is near, advances a few paces, lays his burden down and returns to dig. Again he appears and puts a second ball besides the first, and so on till there is a long even row of them. A second row is then laid alongside the first, then a third, and a fourth; then a passage is left, after which a few rows more are laid down. So rapidly is the work done that the tide has scarcely retired when the whole beach is chequered with flowerlike patterns radiating from a thousand holes. These are the work of infant 
crabs mostly, for as they grow older they venture to retire further from low water mark, where the sand is dry and will not hold together in balls. Then they bring it up in armfuls and toss it to a distance. But, old or young, their houses are swamped and obliterated twice in every twenty-four hours, and twice dug out again; from which you may judge what a life of labour the sand crab lives.

He is, I think, the noblest of his race. Living on the open champaign of the white sea-shore, he learns to trust for safety to the keenness of his sight and the fleetness of his limbs. Each eye is a miniature watchtower, or observatory, and his legs span seven times the length of his body. When he runs he seems to be on wheels: you can fancy you hear them whirr. But, keen as is his sight and amazing as is his speed, he more than needs it all; for, alas! he is very tasty and all the world knows it. In his early days the sandpipers and shore birds, nay, the very crows and, proh pudor! my turkeys patrol the water's edge, and he scarcely dares to show his face by daylight. Then, as he grows beyond the fear of petty enemies, he comes within the ken of greater ones. The kite, sailing high 
overhead, swoops like a thunderbolt and carries him off. The great kingfisher, concealed in an overhanging bough, watches its opportunity, and when he has wandered far from his hole, darts upon him and scoops him up in its long beak. The kestrel hawks him, dogs hunt him in sheer wantonness, jackals hunt him to eat him, owls lie in wait for him, and when he takes refuge in the water, an army of sharks and rays is ready for him. And man closes the list.

"Those wild eyes that watch the wave

In roarings by the coral reef"

are watching mostly for crabs. He is drawn from his hole with hooks, dug out with shovels, caught in traps, netted with nets, and even in the darkness of night distracted with the sudden glare of flambeaux and knocked over with sticks.

Many are the ways in which the race of crabs have sought to shun their thousand foes, some by watchfulness and wisdom, or cunning and skill, some along paths of degeneracy and shame. In the æons long gone by, it seems, there lived a craven crab who condescended to seek safety by thrusting his hinder end into an empty shell, and to-day his descendants are as the sand on 
the sea-shore for multitude, dragging their cumbrous houses about with them and thrusting out their distorted arms to pick up food, and shrinking in again at the least sign of danger. Safety they have bought with degradation, but there are moments of supreme peril even in the base life that they lead; for the crab grows and the shell does not, and it is an inexorable law of nature that, when you change your coat, you must put off the old before you put on the new. The most ludicrous sight I ever saw was two hermit crabs competing for an empty shell. Neither of them could by any means take possession without exposing his naked and deformed posteriors to the mercy of the other, and this he dared not do; so they manœuvred and circled round that shell and made grimaces at each other till I laughed like the blue jays in Jim Baker's yarn.

Others of the race have tried to win security by burying themselves in the mud at the bottom of the sea and stretching out their beggar hands for food. The hands work hard, but the stomach is starved, and in some of this family the body has dwindled into a mere appendage to a great pair of claws. Of these is the giant from Japan, whose grim skeleton, eleven feet in stretch of limb, 
adorns the walls of the Bombay Natural History Society Smaller specimens are common about Bombay.

Then there are crabs which make their backs a garden and grow seaweeds and even anemones, under whose umbrageous shelter they roam about the bed of the ocean in æsthetic security.

Midway between the mud crabs and the sand crabs is one whose ingenuity and adroitness rescue it from contempt. Its hind legs are transformed into an absurd pair of shovels, and the length of its eyes is simply ridiculous. If you have patience to sit perfectly motionless for a time at some spot in Back Bay where the retreating tide has left a dead level of oozy slime, you will see a hundred of these little blueish creatures moving about and collecting some form of nourishment from the mud with their quaint and crooked claws; but move a hand, and presto! they are gone. In an instant they have put themselves under the mud and left nothing, except perhaps the points of their long eyes, in the air.

Then there is the Calling Crab, which has fostered one hand until it has grown into a veritable Roman shield, behind which the owner may shelter himself, calmly taking his food with the other. How these hold 
their own I cannot tell. They are not strong, nor yet swift, nor wary; but wherever the sand is soft and black, they people the shore in countless numbers. It may be that that blazing muster of gaunt, mailed hands in orange and red, ceaselessly beckoning to all the world to come, tries the courage even of a hungry crow. I am inclined to think this is the exp'anation of the matter, for I have often seen one of the feeblest of the mud crabs collect in dense squadrons and perform long journeys over the open shore, with nothing to protect them from wholesale slaughter unless it was the fear inspired by such an ominous mass of leors and arms.

Where the foaming waves dash themselves against rugged rocks and moss-clad boulders, with black fissures between, and here and there a clear pool, tenanted by anemones and limpets and a quivering, darting little fish, chafing in prison till the next tide shall come and set it free, there the sand crab is replaced by the crab of the rocks, most supple-limbed of living things. How it turns the corner of a mossy rock, as slippery as that

"plug of Irish soap

Which the girl had left on the topmost stair,"

and awaits unmoved the onset of a great wave, then 
resumes its meal, daintily picking off morsels of fresh moss with its hands and putting them into its mouth. A life of constant watchfulness it lives and hourly peril, as many an empty shell in the pool bears witness. Its direst enemy, I believe, is the ghastly octopus, that ocean spider, lurking in crack or crevice, with deadly feelers extended, alive to their very tips and ready for the unwary. That this gelatinous goblin should be able to master the mail-clad warrior is wonderful but true. All his armour and his defiant claws avail nothing against the soft embrace of eight long arms and the kiss of a little crooked beak.

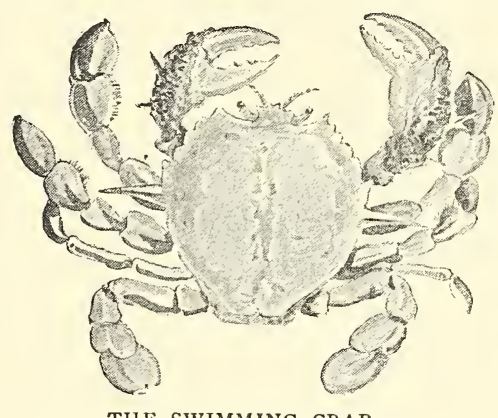

THE SWIMMING CRAB.

Though their proper home is the border line between land and water, the crabs have pushed their conquests over nature in all directions. Some swim in the open sea, their feet being flattened into paddles, and these are horribly armed with long and sharp spines for the correction of greedy fishes. They have been found in the Bay of Biscay, a hundred miles from land, and are common on the 
coasts of England; where they are said to kill large numbers of mackerel. Bombay fishermen often find them in their nets. Other crabs inhabit the forests, climbing trees. Of these we have one beautiful species, all purple and blue.

Others have their home in the fields, lying buried during the months of drought, and coming to life when the rain has softened the earth. They love the rain, and often have I drawn them from their holes by means of a fraudulent shower from a watering can. Slowly the poor dupe comes out to enjoy it, and when his feet show themselves at the door, you can thrust in a trowel and cut off his retreat. Then he knows he has been fooled, and backing into a corner, extends his great claws and defies the world.

Did you ever see a motherly land crab with all her children about her, leading them among the tender grass on which they feed, like a hen with her chickens, and when their little legs are weary, gathering them into her pouch and carrying them home? It is a pretty picture, and I wish I could paint in the father of the family; but the truth must be told, and I am afraid that when he meets with his offspring, he runs them down and eats them. At 
least I saw such a chase once. Never did crab flee as that little one fled from the chele sequentes of his dire parent. He doubled and dodged and ran again, but all in vain! He was caught and nipped in two. Then came Nemesis in the form of my dog, and the pursuer was pursued. In his flurry he lost his way, and darting into the wrong hole, all but fell into the arms of a kigger crab than itself. Darting out again, he was instantly crushed by a great paw.

You may ask how I know that the big crab was father of the little one. I do not know that he was ; but what does it matter? He did not know he was not.

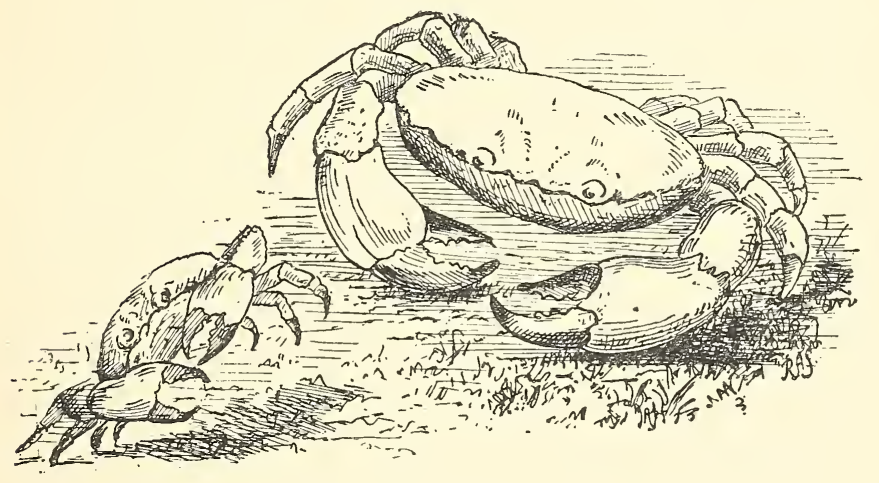




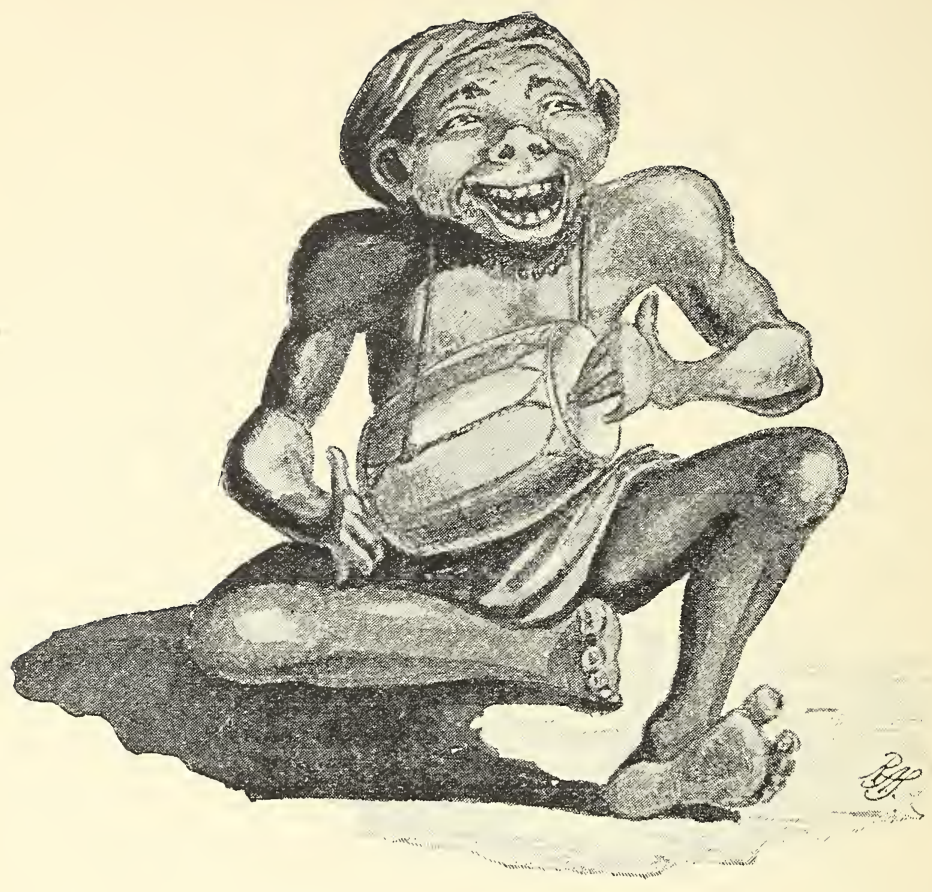

Chapter III.

\section{THE VOICE OF MIRTH.}

"THE time of the singing of birds is come, and the voice of the turtle is heard in our land." How quickly every sense tells you that the mysterious tide of life has ceased ebbing and begun to flow; in short, that Spring is begin- 
ning. Very soon the fierce din of the Cicada will start from among the trees. Why do these creatures thus weary themselves with unprofitable noises? This question is like some potent spell, for in an instant it seems to call up the new spirit, that way of interpreting the universe which was born but yesterday and already domineers over us all. Our fathers would have answered, "They sing because they feel merry," but we must not do so. That answer is no longer admissible. We must devise something to the effect that in the struggle for existence, prolonged through inconceivable ages, those birds and insects which produce sounds doubtless attracted the attention of the opposite sex more successfully, and so forth.

But I am going to make myself a butt for scorn by maintaining that the former is the correct answer. As I sit at the door of my tent after dinner, the whole air is murmuring and tinkling with the voices of crickets and grasshoppers and little frogs. There is one melodious sound, a sweet repeated trill, which I have never been able to trace to its source. I have followed it up till I thought it was in a tree over my head, but it is more like the voice of a frog than a cricket. Perhaps it is a tree frog. There are also little frogs in the rice field, and black crickets 
under stones, and green crickets shrilly squeaking in the bushes.

Is the key to all this, "Cherchez la femme"? I do not believe it. Why should we devise explanations of matters that need none? When an animal is well and happy, there is an overflow of nervous energy, a surplus beyond what it requires. The Wagtails and Redstarts let it off by shaking their tails, and the crickets and the frogs and a hundred others let it off in noise, and

" the sailor lad

Sings in his boat in the bay"

and

"the fisherman's boy
Shouts with his sister at play."

Besides, do you think that man is the only animal which feels the monotony of doing nothing? All living things feel it, till you get so low down in the scale of life that they can scarcely be said to feel anything at all. When they are not sleeping or eating, they must be doing something pour passer le temps. To some, indeed, nature has been kind and given them an interesting occupation for their leisure hours. To the dog, for instance, she has given fleas, so he can lie on the carpet scratching his ribs, biting his feet and worrying his person passim, and the time never hangs 
heavy on his hands. I have no doubt that flies do in the same way a great service to horses. What would a horse do in the stable all day, tied head and heels, with no occupation, if he was not obliged to whisk his tail? Of course the horse does not see the thing in this light. He is like his betters, who rarely recognise their best blessings. But I, as a looker on, find that the fly in moderation is a blessing, and that every animal to which nature has not given some pastime has invented one for itself. Schoolgirls nibble their nails, Yankees whittle wood, the Hindoo peasant chews beetle-nut and scratches his thighs, ducks quack and crows caw. And if you attentively consider the prattle of any talkative child, you will find yourself compelled to put much of it into the same category. The sounds which the child makes take the form of words and the words throw themselves into sentences because it has learnt the trick of speech, but the occasion of them is not that it has anything to tell, or anything to ask. It often begins to speak without knowing what it is going to say. I should like to believe that this applies only to the prattle of children. But let us change the subject.

From mere sound it is an easy step to rhythmical sound, and there you have the birth of music. A sound serves to 
pass the time, but a sound repeated at regular intervals soothes the savage breast and inspires ecstasies of joy. How or why it does so I cannot tell, but the fact is not open to dispute. In the valley just below me a man is playing the tom-tom and will do so without stopping till to-morrow morning. On he goes, tum-tara-rum-tum, tum, tum, tum, tum; and I have no doubt an admiring audience is sitting round him. He did not acquire that art to please the ladies, but to please himself. You may say he does it because he is paid for it, and of course he does, but that does not affect the argument. Men pay him because he gives them pleasure, but he has the power to give them pleasure just because his own sense of it is keener than theirs.

While I was listening to the tom-tom my ear caught the notes of a musical cricket at the root of a tree quite close to me. Most crickets repeat one note monotonously, but this was evidently a talented cricket. It had two or four short notes and a long one, and I found, by beating time to its song, that the rhythm was faultless. Where, then, is the difference between the cricket and the tom-tomwalla? Nowhere. They are both musicians of the first degree, proficient in time, but not attaining 
to melody. I am afraid we often allow ourselves to speak contemptuously, and therefore foolishly, of native music because we do not understand this matter. The first stage in the development of the musical faculty is the sense of time, and in this the Indian musician is incomparably superior to the European. His time is faultless and very complicated. You may not be able to enjoy his strains, because you have arrived at a higher stage, just as you now call books childish which would have charmed you when you were a child. But the music of time is music still, and the drummer-boy is a living witness to its mysterious power over the hearts of men.

Now it has struck me, as it may have struck others, that there may

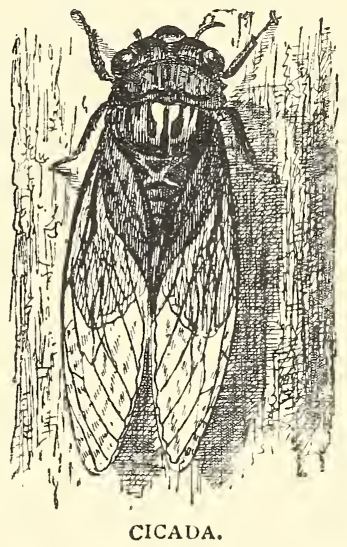
be a rhythm in the shrill tones of a cricket, which we have not the keenness of sense to detect. The song of the Cicada appears to us to be one long note, a protracted, ear-rending scream; as if one were drawing an iron nail across the teeth of an endless iron comb. But 
the teeth of the comb might be adjusted to each other as nicely as the chords of a piano, and so may the scream of the Cicada consist of an inconceivably rapid succession of tones which throw him into an ecstasy, though our ears are too gross to separate and distinguish them. We speak of the seven colours of the rainbow, and to our eyes they are only seven, but ants discern an eighth, and are violently agitated by it.

If you feel contentious, you may ask, How can the Cicada enjoy its own music, having no ears? This objection rests on the fallacy that, because we hear with ears, nobody can hear without them. I have actually been told, by a nineteenth century man, that the pipe of the snake-charmer is only meant to fool us, since snakes have no ears and cannot hear it. The pipe of the snake-charmer! You could hear it with your bones. But let that pass. Fishes have no more ear than snakes, but the fishermen of this coast drive the mackerel into their nets by shouting and striking the sides of their boats with bits of hard wood. And now we are told that snakes and scorpions and spiders, at the Zoo, have been worked into wild frenzies by the tones of a violin.

However, this proves nothing about the Cicada, and I 
am not going to be guilty myself of the fallacy that, because an animal makes a noise, it must be able to hear it. But I say this : Let the Cicada be as deaf as you will, yet the rhythmical vibration of its wonderful drums may thrill through its own body and stir its whole nature as effectually as the pibroch stirs a Highlander. Imagine an animate violin, and you can have no difficulty in imagining that it enjoys the music played upon it. I like this theory because it quite snuffs out the idea that the Cicada sings to please the ladies. $\mathrm{He}$ can please nobody but himself.

But I will not lie under the imputation of wishing to despise the influence of the ladies. Grant me that the shout and then the song were at first the escape pipes of a gleeful spirit, and I will freely grant you that these and every other accomplishment will be perfected and paraded to win the regard of the fair one. There are few sights I love better than the courting of birds. Sweetly does the Magpie Robin sing in the small hours of the morning, when we are in our beds, but if you want to know what he can do, look at him and listen to him as he follows "the fair, disdainful dame" and his rival from branch to branch 
and tree to tree, suffering the ecstatic pains of a jealous suitor. What a masher he is in his new spring costume, with his black and white tail expanded like a fan, and his glossy breast at the very point of bursting with the frenzies of song which spout and gush from his swollen throat! It may well be that

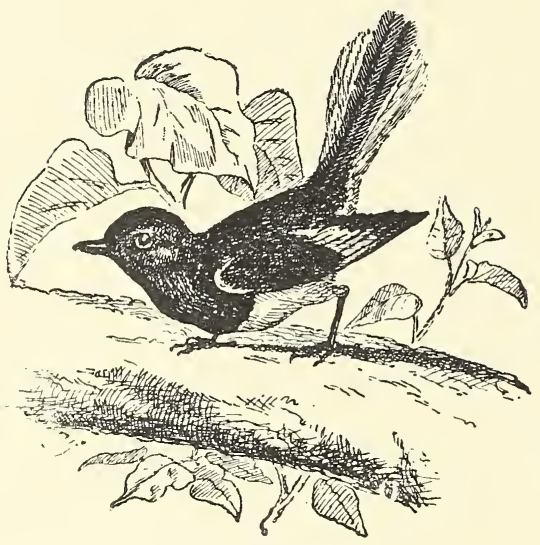

MAGPIE ROBIN. the same all-pervading influence calls forth the highest efforts of the cricket, but he sings in solitude and in mournful tones, as if of slighted love.

Thus, on one side, is the trivial faculty of sound-making seized upon and turned to account by the sublime and almost unearthly faculty of discerning and enjoying "the hidden soul of harmony." On the other side it is brought into servitude by quite another faculty, and sound grows into language; but how great a subject is that! Perhaps one day it too will have its Max Müller. 


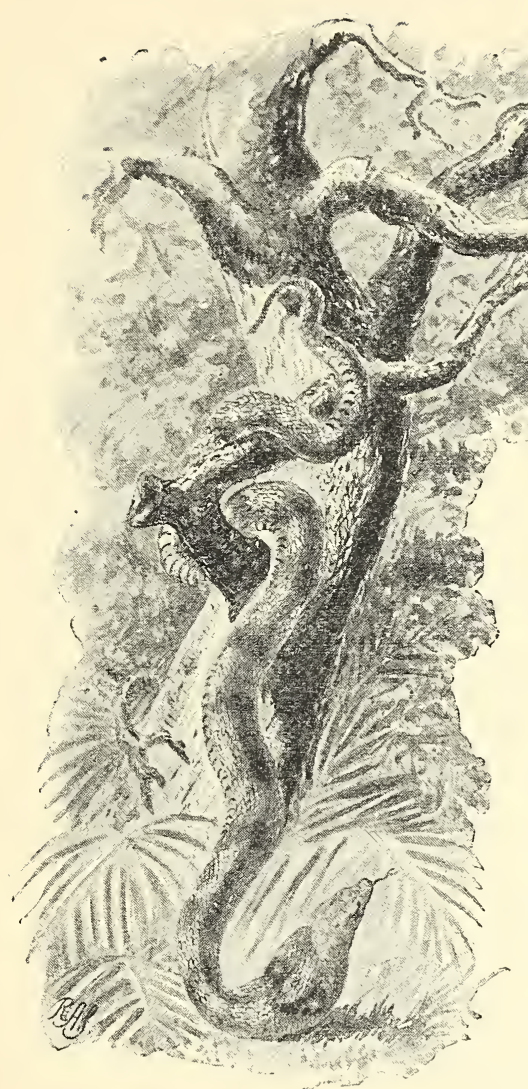

\section{Cilapter IV. \\ THE KING C O B R A.}

THE weather is getting very warm. This is perhaps not expressive enough. What I mean is that the atmosphere is getting like that which we may imagine to prevail under a pie-crust when the pie is in the oven. Of course I am writing from the coast. Up-country, on the plains of the Deccan, the atmosphere of the oven outside of the pie furnishes a better illustration. This is just the difference between the two 
climates. In the one you are toasted on the outside and baked all through; in the other you simmer day and night, and get out of your bed in the morning sodden and juicy. The strange thing is that the thermometer registers nothing very outrageous. There is some influence abroad other than heat, some electric spell forbidding the air to stir. The trees stand as still as statues, and the white clouds in the blue sky are motionless too. Your ardour for manly pastimes and active exercise abates, to say the least of it, for your muscles are like a jaded horse which will not answer to the spur, and anything like a long walk in the morning endows you with a thirst which will not leave you all day. It is not a wholesome thirst either, not a demand of nature for refreshing forms of moisture, but a kind of glutinous thickness such as troubles the throat of the office gum bottle. At such times it seems right and reasonable to be lazy, but it is bad policy. Heat, like most of our enemies, gives way to a bold front, but tyrannises over those who yield to it. And from a naturalist's point of view this is the very time to prowl, for this heat: which seems to drain our strength away has just the opposite effect on the baser forms of life. 
On every hand you may see signs of its re-vivifying energy.

Trees which have long stood bare are dressing themselves in the brightest of green, while others are trimming the dark robes of last season with the pink and red of a new growth. The colour of the hills is changing and growing more beautiful every week. Orchids are blooming, and the wild jasmine is covering whole trees with the pure glory of its white blossoms. Every morning they bloom and fill the air with their fragrance, in the evening they fall and whiten the ground. Not so effective as the jasmine, but very like it and almost as sweet, is the Corrinda blossom, and I know no more dainty bouquet than mixed clusters of white Corrinda and scarlet Ixora. But the flower of the Corrinda is only a promise, and the fulfilment is better. When a bush in full fruit and I chance to meet, we seldom part without a long and pleasant interview; for the love of fruit is a thing which I have always tried conscientiously to foster in myself. I regard it as a vestige of Eden and a token of a palate still undepraved by the artificial consolations to which Adam turns from the thorns and thistles and the sweat of his face. But to be rightly enjoyed, fruit must be 
eaten as in Eden, without knife and fork, or plate and spoon, plucked from the tree with the bloom still on. Unfortunately the Corrinda bush and I have these pleasant interviews less often than we ought. The wretched people on this coast feed on boiled rice, and the second necessity of life to them is some strong vegetable acid, or corrosive pickle, which will spur the insipid mess down a reluctant throat. They scour the country for tamarinds, green mangoes and Cocum, or wild mangosteen, a fruit so ferociously tart that when once I ate it, many years ago, I had to send my face to the dhobie to get my crumpled features ironed out. So they will not let the Corrinda berry ripen, but strip the bushes while it is yet green and sour and convertible into pickle. But some escape for me.

Another tasty fruit which is ripening now is the Char, or Charolee, a little purplish brown berry with a hard stone. One morning last week I found a fine Char tree lying across the road; it had just been cut down. I could not guess the object of such wanton destruction, but my puttiwalla explained it at once. The upper branches of the tree were full of fruit, and the lower branches were full of red ants. Some koonbee had coveted the fruit, but dared not face the ants; so out came the koita and 
down came the tree. Not half-an-hour could have passed since the deed was done, so the perpetrator must have fled at the sound of my footsteps. I went on my way, but had not gone far when I spied two village youths skulking about the jungle. They looked at me, and I looked at them and knew by natural divination that they were guilty. Then I saw them furtively slipping something into their mouths. It was berries of the Char. Should I have been a wrong-doer if I had arrested those youths and simply held them fast for half-an-hour among the lower branches of the fallen tree, that its natural guardians, the red ants, might "examine" them as the Romans used to examine suspected criminals? I did not do that, but I did something else. I will not tell what I did.

Now all these fruits and flowers and tender leaves are food for one thing or another, so I see that butterflies, which have been scarce for months, are appearing again, and bees are gathering honey, and many of the birds are busy about their nests. On every hand I hear the great Golden-backed Woodpecker hammering at the trees, and parrots are rushing wildly through the sky in a noisy state of excitement about their domestic affairs. 
The same morning on which I found the fallen Char tree I saw two birds scuffling in the air. Feathers flew thick. At last they fell to the ground, and I saw that one was a Myna and the other was a Barbet, that clumsy green

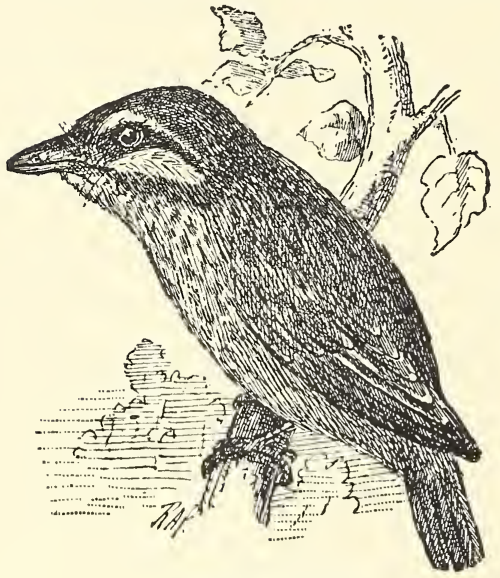

GREEN BARBET.

bird which the natives call kootroo, from the monotonous call with which it makes the valleys resound at this season. Then I knew what it was all about. The sturdy Barbet nests in trees, like the Woodpecker, and makes its own hole. The gay Myna nests in trees too, but appropriates a hole made by somebody else. In single combat the Barbet, though smaller, was much the better man of the two, but the Myna had many friends, who all came to see what was the matter, and talked a great deal and wanted to arbitrate. The Barbet turned upon them and went at them one after another, but they generally dodged him, and the rest applauded, so he was panting and looking very flushed in the face, while they were quite cool. He 
caught one a good punch in the ribs, however, and a handful of feathers flew out into the air, which must have been a very distressing loss to a well-dressed Myna at the beginning of the wedding season.

This same mysterious influence, which is ripening the Corrinda and awakening the butterfly, is also developing the deadly Nux vomica and revivifying the venomous snake, as I was very graphically reminded not long ago.

I was returning one morning from my walk over an undulating, grassy plain, dotted with islands of small trees. Never have I seen the wild jasmine more beautiful. Suddenly I was met by some men with the news that a large python was in a tree not far away. A python, if more than five or six feet in length, is too thick and strong to be killed with a walking-stick, like cobras and other snakes; but my little collecting gun was in my hand, so I followed them at once. When we reached the place I found a number of koonbees assembled, talking with bated breath, as if in the presence of some great danger. Why should they be afraid of a python? It is not a poisonous snake, but one of the Boa constrictor tribe, squeezing its prey to death. It lies motionless for hours, or days, or weeks if necessary, until some hapless monkey, or jackal, 
comes within its reach. Suddenly it darts forward, and next moment, by some process which the eye cannot follow, the python is wound round that monkey, or jackal, and in a few minutes more the life has been squeezed out of the shapeless body. Then the python unwinds, and turning the corpse round so that its head points towards him (lest the hair should rub the wrong way), yawns like the grave that he is and introduces the head into his throat, down which, with slow solemnity, the funeral marches, and the grave is closed.

These are facts; both the jackal and the monkey are historical. But there is no instance on record of a python swallowing a man, and most of us are familiar with the snake-charmer who presents himself at the door with one wound about his limbs; so the alarm of the villagers surprised me. However, koonbees are strange creatures, so I asked where the beast was, and the boldest of them undertook to show me. He guided me silently into a clump of trees and pointed upwards. I could see nothing. Yes, yes! I could get glimpses of great coils among the boughs, and there, quite plain, was a white throat and a cold, cruel visage deliberately watching me. Surely no python ever looked like that. A python's eyes look 
nowhere in particular; this creature's met mine with a truculent stare like nothing I had seen before. I did not like it, so I took careful aim and lodged a charge of small shot into the brute's neck, six inches behind his head. He started, and motion began among the coils. By degrees his hold upon the branches relaxed, and after a long time he fell, or rather slid, with a heavy thud to the ground. A buzz, as of bees, ran through the crowd, with earnest shouts of warning meant for me, and now I understood.

The great brute writhing on the ground was not a python, but a Hamadryad, or King Cobra, a venomous snake and the most terrible of the whole serpent tribe. The koonbees had known this all the time, and hence their terror, for the King Cobra does not strike in self-defence only, like other snakes, but attacks man and pursues him with terrible fury. On this side of India, happily, it is rare, and I had got a prize, for this specimen was 12 feet 6 inches in length and must have cast its skin quite recently, so bright and fresh were the bands of yellow scales across its glossy brown back. It was past mischief now, for the charge of small shot had severed the spinal cord and interrupted all communication with head-quarters, so, though all parts of it moved, there was no concert in the motion. It neither 
went one way nor another, nor lifted its head to strike. Yet not one of the natives would come near it. At last I seized it by the tail and began to haul it out into an open space, making a broad track among the dead leaves. A cry of utter horror rose from the villagers, but a Kiristan (i.e., a man who professes the Christian religion) came to my aid. Finally, as the writhing grew less violent, I persuaded the men to cut two poles and secure the slippery coils with tough vines, and so I brought home my spolia opima in triumphal procession.

On the way I learned some things about the King Cobra which are not generally known. So swift is it that, when it pursues, escape by flight is impossible. When it has caught a man it swallows him whole, then, climbing a tree, it winds itself round the trunk and tightens its coils until the man is crushed all to nothing in its inside. Thus it digests him. Facts like these are becoming increasingly rare in books. You must glean them among the simple folk who spend their lives with the beasts of the field and from infancy hold converse with nature's charms and view her stores unrolled. I have gathered many such, very wonderful and known to few. Another day perhaps I will give you some of them. 
The Secretary of the Bombay Natural History Society is very angry with me for killing the King Cobra. He says a live one of that size would be worth a king's ransom. Next time I fall in with one he shall have the contract to catch it.

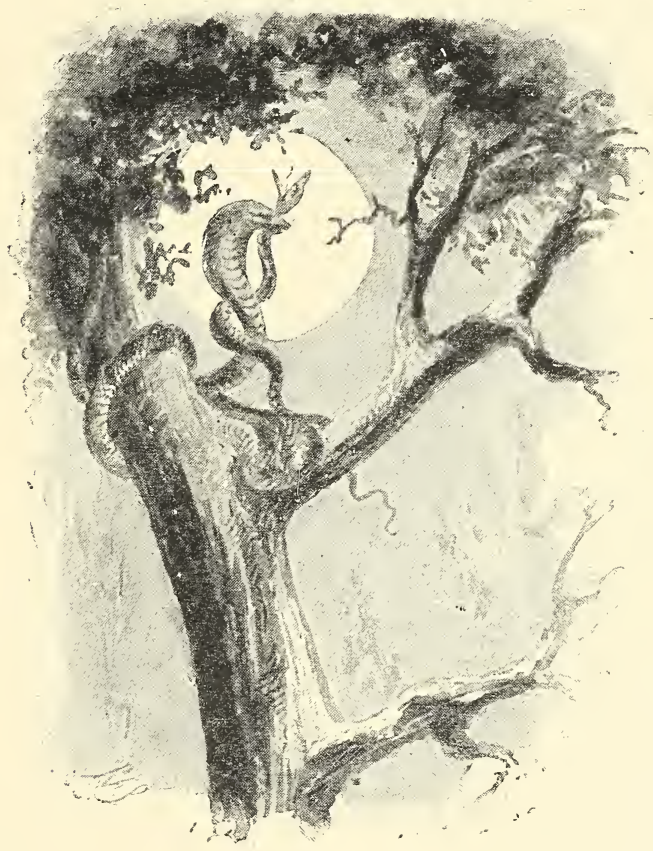




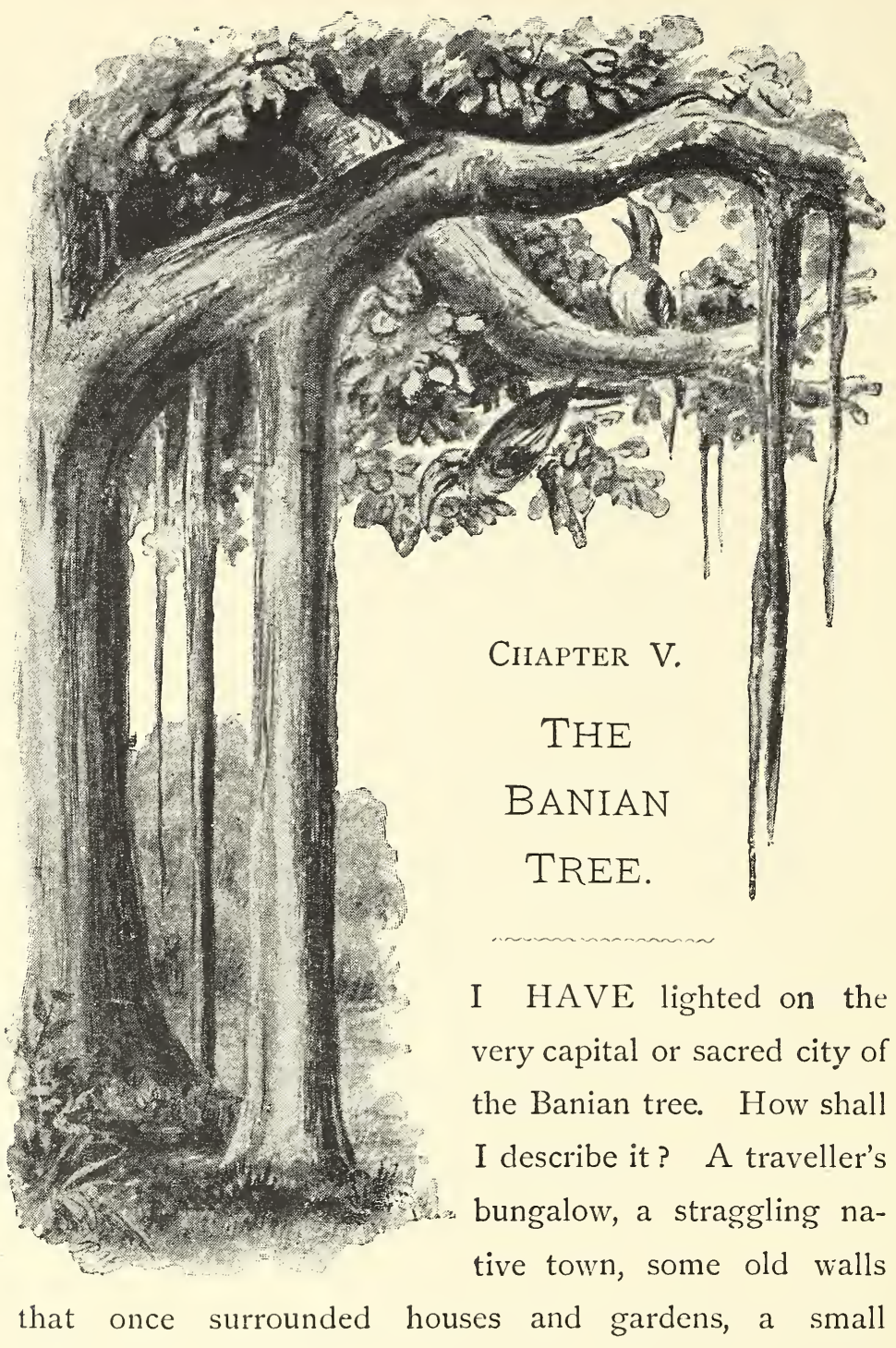


dilapidated church, a cemetery with a few old tombs, whitewashed and bordered with blue by the P. W. Department, a bandstand, a monument, the foundations of a jail, and in all directions winding roads, with old Banian trees meeting overhead, so that you may walk where you will and scarcely see the sun.

At some time or other it entered the mind of somebody or other-nothing is known of the when or the who-to plant the sides of the roads with these trees, and while the walls have been crumbling the trees have been growing. This deserted and dismal place was then a civil and military station of some note, and those were easy times, when the lack of pence did not vex our public men, and things were done with a large and liberal mind. Now, too, we plant roadside trees. We plant them, and when they have grown up and begin to be of some use, we hack them down again, because the rain dripping from their leaves is supposed to damage the roads.

I once remonstrated with a muccadum whom I saw superintending this work. I told him that even native Governments had always regarded the planting of roadside trees, to give the weary traveller shade, as an act of piety and an antidote to the sins of previous births, and that he 
was wickedly undoing a good work which had cost much public money. He replied, "Not so. I do not destroy the roots of the trees. I only cut away the branches which spoil my roads." I said, "O ! I understand. It is the roots that give shade to the traveller." It is not often that sarcasm or irony strikes any light from the flint of a Hindoo mind, but I got a flash out of that muccadum. But then, you see, he was a muccadum.

Another thing that makes futile much of our roadside planting is the erratic selection of trees, without any regard to whether they will grow or do any good where we put them. There is a Forest Department which ought to understand such matters, and-but what am I saying? Fancy a Forest officer neglecting his pastures and grazing fees to meddle with roadside trees! They come under the major head "Roads," as every child knows, and it is of course the province of those who make the roads to build the trees also. The best results are obtained by committing the work to a minister of the "Lokil Phund." He has one luminous idea on the subject, and it is that two or three trees of different kinds should always be put into one hole; "for," says he, "if one dies, the other may live." So he puts a Jack and a Mango, or a Tamarind and a Casuarina, 
together, and lets them fight it out. I would not be a laudator temporis acti, but it does sometimes seem as if they managed matters better in the old days when there was no Lokil Phund, nor even a P. W. D.

How these Banian trees have thriven! Over and through the crevices of the rough laterite rock their tortuous roots have sprawled like the feelers of a giant octopus, while overhead they streteh their arms and shake hands across the road, making a shade that never fails from sunrise till sunset. Some are older than others, or else they have found a kinder soil. Just in front of me, as I write, are two giants, patriarchs of their tribe, standing side by side. Their united shade covers a space of 200 feet in length by 150 in breadth. Each stands on a central pedestal composed of many columns, some welded together into a composite trunk and others grouped about it, while on either side a single, tall pillar props a great, over-weighted arm, like Aaron and Hur staying the hands of Moses. From other boughs slender roots hang down, seeking the earth, but never finding it, for their points are soft and succulent, and hungry cows bite them off as soon as they come within reach.

Did you ever explore a noble Banian tree and make a 
study of it? Of course you know the tree I mean, Ficus indica, the Indian Fig.

" Not that kind for fruit renowned, But such as at this day, to Indians known, In Malabar, or Decan, spreads her arms, Branching so broad and long that in the ground The bended twigs take root, and daughters grow About the mother tree, a pillar'd shade, High over-arched and echoing walks between."

How Milton came to know about Malabar and the "Decan" and this wonderful tree is not so curious a question as it looks. Of course he had read Pliny's account, for he copied his error about the bended twigs taking root, but he did not need to depend on Pliny. There were Anglo-Indians in London before Milton's time, and we may be sure they were much greater lions than they are now. Not twenty-five miles from here, a few days ago, I looked on three graves, solid squares of masonry with a flat stone slab on each, bearing an inscription, rudely cut and inartistic, but still plainly legible. The first ran thus :-

Here lieth the body of William Barton, Chyrurgion, dec. XXX November, Anno Dom. Ni. Salv. Mundi MDCXXXVIII.

1638.

W'ILLIAM BARTON. 
The other two told the same story of George Wye and Antony Verneworthy, "Marchants," who deceased in the year I637. The straggling letters covered the whole face of the stones and left no room to tell more, and besides the stones there is none to tell us ought of William Barton, George Wye and Antony Verneworthy. Of course they were servants of the Hon. E. I. Company, but what manner of men were they, how long had they been in this land, and how did they meet their deaths?

You may guess what you please, for we shall never know, but of one thing there can be no reasonable doubt. They had all seen the Banian tree and sat under its shade. And, though they were fated to lay their bones beside it, some surely of those who uttered words of faith and hope over their mortal remains, and committed their memory to these faithful stones, must have lived to return after long years to their native land and tell of the strange things they had seen. And they had seen few stranger than the majestic fig-tree which sent down to the ground roots from its branches and made to itself crutches for its old age. Nor is there any doubt that the tree owes the name we now give it to these men. Being "marchants," their dealings were with those 
who followed the same vocation as themselves, the Bunnias or Banians. Read this old record :

"A people presented themselves to mine eyes cloathed in linnen garments, somewhat low descending, of a gesture and garbe, as I may say, maidenly and well-nigh effeminate; of a countenance shy and somewhat estranged, yet smiling out a glozed and bashful familiarity. I asked what manner of people these were, so strangely notable and notably strange. Reply was made that they were Banians."

Naturally these practical merchants thought Banian meant Hindoo. They divided the people into two classes, Gentoos and Moors, and the Gentoos were also called Banians. So when they spoke of the notable Hindoo tree, they called it the Banian tree. Of course the sacred tree of the Hindoos is not the Banian, but another fig tree, the Pepul; so in one sense the old merchants made a mistake; but it is much easier to account for their mistake than for that of the Hindoos in not choosing the Banian for the holy tree. How they came to select the Pepul instead puzzles me altogether. I once asked an intelligent Hindoo to account for it, and he told me the reason was that the ancient Rishis used to sit under the Pepul tree. But the superficial man was only pushing the question away from him. Why did the ancient Rishis sit under the Pepul tree? 
Since I began to write this a profoundly philosophical friend has suggested an explanation which I do believe is the true one. The peculiar heart-shaped leaf of the Pepul is sensitive to the faintest breeze, and you will often see it flapping gently when the white clouds are standing still in the sky and not another tree bears witness to the least motion in the air. Now those Rishis were wonderful fellows, as Colonel Olcott knows. They had got to the very bottom of the well where truth is found ; they lived there, in fact. They had got

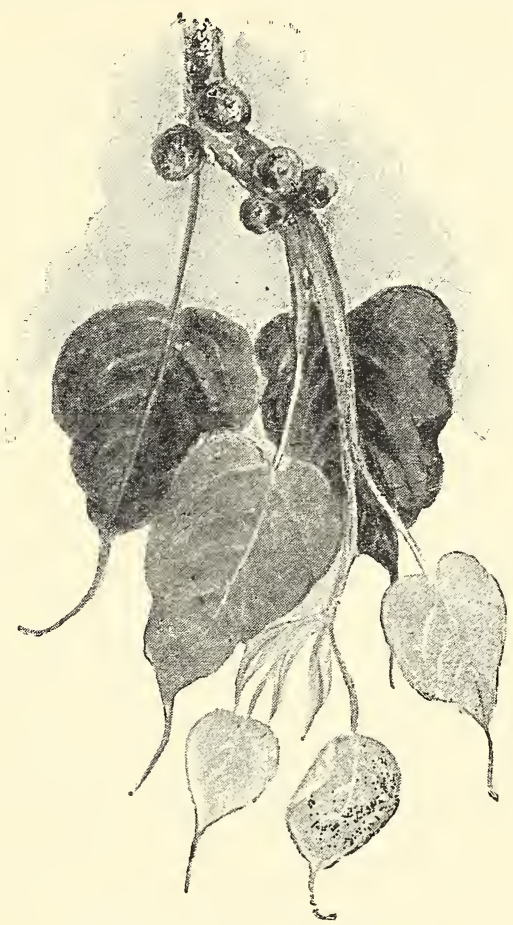

PEPUL LEAF (Ficus Religiosa). the victory over delusion, and discovered that everything is the same as everything else, and all things are nothing and nothing is all things, and cause and effect are one So when 
the Rishi saw the flapping of the Pepul leaves on a sultry day, he sat under the shade of the tree and knew he was cool. And he blessed the tree that fanned his sacred limbs.

Nevertheless, the shade of the Pepul is a fraud. It never has any when you want it. But the leaves of the Banian come before the heat, and its shade is a shade indeed. And to sit in contemplation under the majesty of a noble Banian would make a man a Rishi if he were not so before.

What a world it is in itself, populous with beasts and birds and myriads of little things, which, though we call them insignificant, are sharers with us in the mystery of life and happiness. And how bountifully the tree feeds them all. It is literally a land flowing with milk and honey. The milk is in the leaves, beloved of goats and sought after also by certain beautiful butterflies for the nourishment of their young. While they are yet pink and tender, the delicately devised Map Butterfly, Cyrestis thyodamas, comes flitting round the tree and commits her eggs to its care. And before that, while the leaves are still packed in sharp-pointed cones, you will find them eaten into by a soft, fat grub, like a large green wood 
louse. Its head and feet are hidden under it, and it walks backwards and forwards with equal ease. This will turn into Iraota timoleon, one of the most brilliant butterflies that ever spread its wings to the sun, though it has no English name.

The honey is not in the leaves, but on them. If you turn over any well-grown leaf you will find a whitish smear just at the junction of the stalk, as if a candle, or a cake of soap, had been rubbed against the leaf. It does not look very toothsome, but it is ambrosia, the food of gods. I believe it is the chief cause of the presence of the little striped squirrels, which make the tree ring with their wild cries.

It is for this also, and not for the fruit, that the redheaded Parrakeets swarm about the Banian tree early in the morning at certain seasons of the year. If you watch them, you will see that they are not eating anything, but clambering about the outermost twigs, too busy even to scream, and that, as they pass each leaf, they stoop down quickly and give it a lick on the under side. How many licks go to make a breakfast I cannot say, but it is evident the little epicures have no time to lose.

Ants also of many kinds are travelling along the boughs 
and twigs, for where there is sweetness there will be ants Then there is a mixed multitude of insects of the baser sort, aphides and hoppers and the like, and to keep them all within limits, there are spiders and lizards also, dark grey geckos, which find just such lodging as they like about the rugged trunk and the old roots that over-

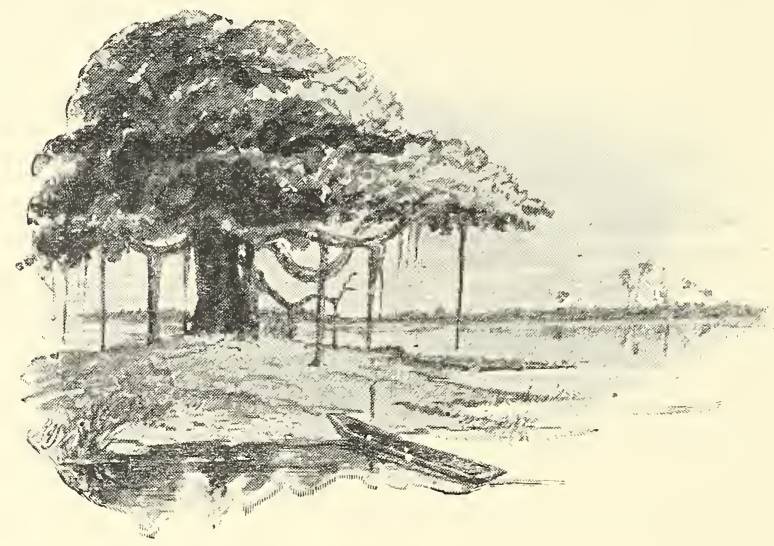

lie it, blending with it and with each other in grand confusion.

But if you wish to form a just idea of the place which the Banian tree fills in the world, you must visit it when every twig is fringed with scarlet figs. If this should be, as it generally is, in the cold season, when food is scarce, 
then there is indeed a bazaar. Early in the morning the birds begin to gather, the riotous Rosy Pastor and the self-possessed Myna, the graceful Brahminy Myna, with its silky black crest and buffy-red waistcoat, and the yet more elegant Hoary Headed Myna, and the cheery Bulbuls and the Coppersiniths, quiet and silent just now, except when they quarrel and rail hoarsely at each other, and the Golden Orioles, and here and there a great blackguard Crow, devoid alike of shame and fear. They are all in high spirits, and plenty makes them fastidious. Watch that Myna as he hops about, judging the fruit with one eye, till he finds a fine, mellow fig, not too raw and not too ripe, but just right. Then he digs a hole in it with his sharp beak. Of Parrots there are not many, for the Parrot is a sybarite and the fig is plain, wholesome fare Another fruit-eater also is absent-the Green Pigeon : its mellow whistle is seldom heard in the Banian tree. The reason is that the Green Pigeon cannot dig holes in fruits : it swallows them whole. Now the Banian fig is tough and so firmly joined to the twig that the Green Pigeon has not strength to pull it off.

It was this fact that first put me on the track of the true explanation of the Hornbill's monstrous beak. It is 
simply a powerful pair of pincers, long enough to give the leverage required for wrenching off tough fruit. Note this and examine the beak of the next Hornbill you see.

When night falls and the birds have gone to bed, then dark flying foxes will flap heavily round the tree, and hooking themselves on, clamber about, chewing and

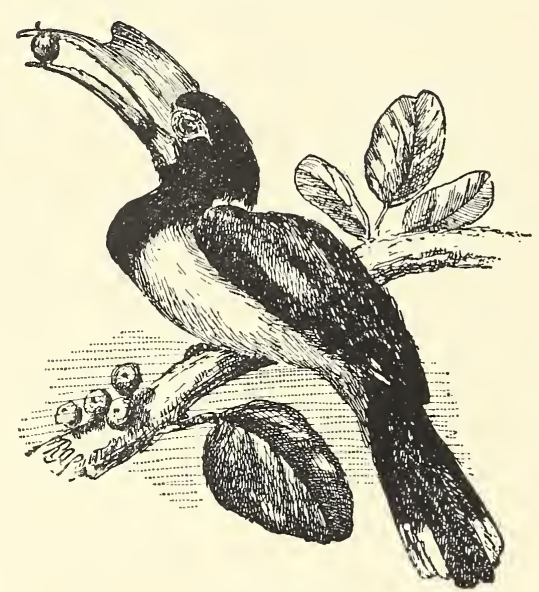

HORNBILL. munching. In the morning the ground will be thickly strewn with the remains of their untidy and wasteful repast. Then a slow procession of spectral cattle will come upon the scene gaunt frames of bullocks and cows and calves, with scabby hide drawn tight over sharp bones, lustrous eyes staring wantingly, and prematurely grown, distorted horns. And they will greedily feed on what the bats have dropped. Poor things! the wide world seems to have no food to spare for them. The ground is bare of grass, and the shrubs 
are bare of leaves as far as their famished tongues can reach. They belong to somebody, of course. A farmer somewhere calls them his. But he does not feed them. Why shculd he? He does not need them just now. In due time the rain will come, and the grass will grow and keep them alive till ploughing time. Then, if well beaten, they will put forth all the strength that is needed to pull his little crooked plough through the muddy rice ground. If the lives of some of them flicker out before that, his loss will be small and his conscience will be free. If he lifted his own hand to shorten their lives, the waters of the Ganges could not purge away his sin.

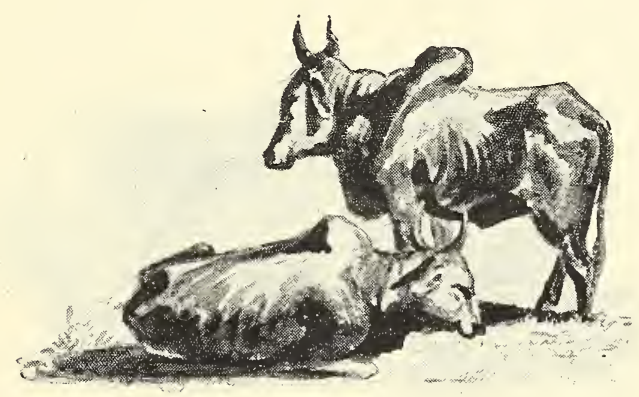

PHARAOH'S LEAN K'NE. 


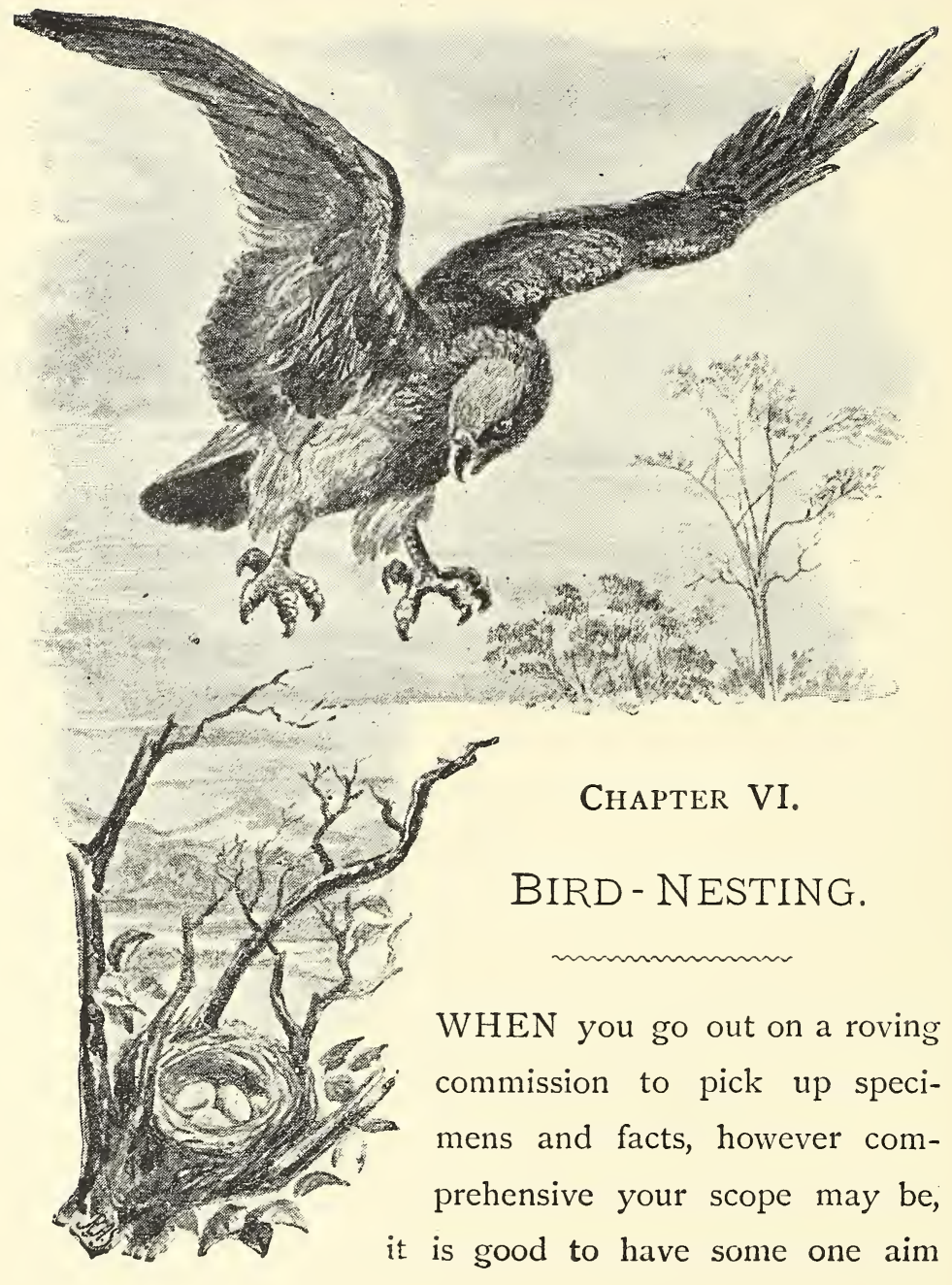


uppermost, just as it is good to have a cox in the crew of a boat. This morning I was out bird-nesting. Of all collectings the collecting of eggs is at once the highest and the lowest. A collection of eggshells is loathsome, a monument of human frivolity and wickedness, worse than a trophy of heads or horns, lower than a collection of stamps. But when the eggs only serve, like counters, to mark the progress of the game, when the whole collection is a record of happy travels in birdland, when every egg is a souvenir of some pleasant intimacy, I envy the owner. What if he is a robber after a sort? What if he took without saying, "By your leave"? It was a keepsake he wanted, and he did not get it till he deserved it. No pursuit demands such close and patient observation, such a knowledge of the home life of the objects of your study. You may live in the same garden with a little bird and meet it many times a day, and never know that it is married and has a family. For weeks the courtship went on under your windows, till she accepted him and left his rival to look for another love. Then the young couple explored every tree in the garden for suitable premises. One branch was tried and rejected on account of the ants, another was fixed on but spoiled 
next day by the pruning knife of the Malee. At length a cosy little site was found close by the path which you traverse every day, materials were collected, and for many days both the birds were busy from early morning building their house. Then one happy day they sat, with mutual congratulations and endearments, admiring the first-born egg. There had never been such an egg. It was the darlingest little egg in all the world. For a fortnight after this he led a bachelor life, coming often, however, to see how she did, and once a day taking her place while she went out for a little air and exercise. Then the little ones came and family cares began in earnest. It was ora et labora, four open mouths and much labour to fill them. All the day long spiders and caterpillars had to be caught and dropped into those little red funnels, all stretched out and quivering with expectancy. Now they are clothed and sitting on the edge of the nest, and their parents are in a flutter of delight and anxiety. And all this has gone on without your getting the least hint of it. The fact is that familiarity with danger has taught birds to combine circumspection with an air of unconcern which would baffle a London detective. It baffles the crow, which is sharper than a London detective. The great lizard, who 
lives in the tree, with his ogre eye on everything, is not so easily eluded, but he can be fought. Only if both parents are away at once will he get a chance. How every collector hates that gourmand! But I scored off him once. He had swallowed the first egg in a nest, and trusted that he would swallow the rest as they were laid; but I put in a chalk egg for his special benefit, and the marks of his teeth next day showed how he had struggled with it before he gave it up in disgust.

But I must return to my walk. I had first to visit the nest of a shrike, which I had noted a week ago. This fearless butcher practises no cunning. His nest is fixed in the thorniest bush he can find, and fenced all round with thorny twigs. He is not much in the way of crows, and if

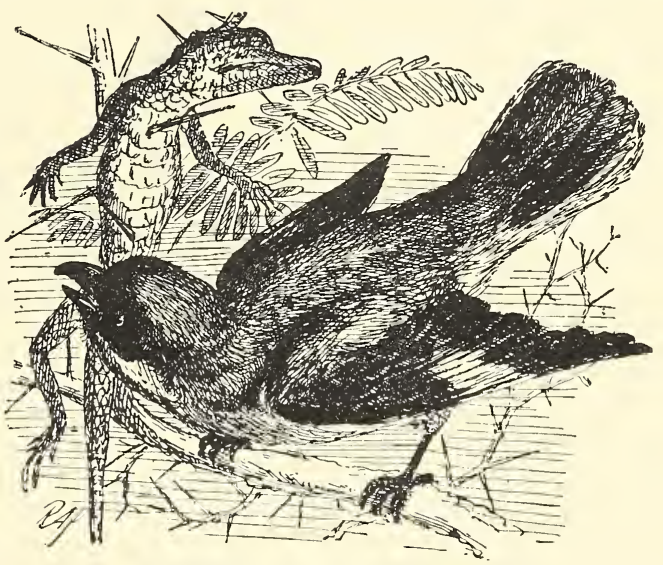
SHRIKE (OR BUTCHER BIRD). any lizard should be so silly as to show itself, it will 
promptly be caught and impaled on a thorn till it is tender enough to eat. No provision had been made, however, against me, and I annexed the eggs without much scruple, I confess, for sentiment does not naturally attach itself to the Butcher Bird. Somehow or other, I have quite a different feeling towards the King-crow. It seems mean to take advantage of the splendid courage with which he builds his flimsy house in the most exposed

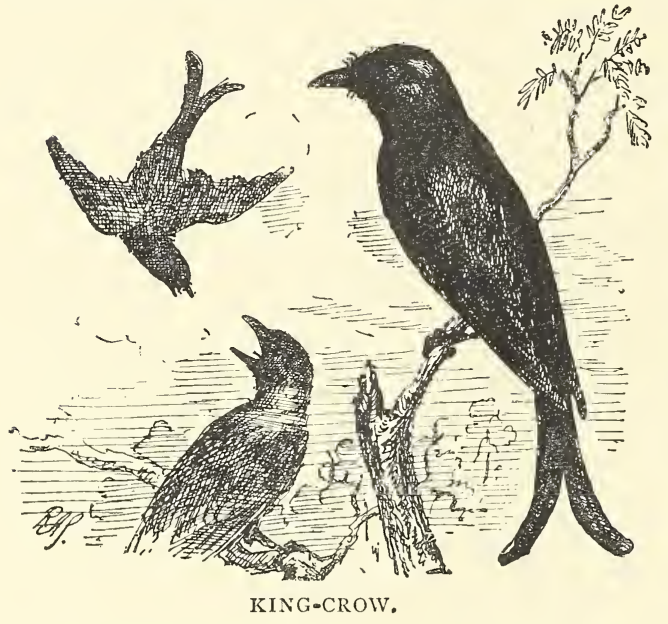
situation he can find, and forbids kites to pass that way, or crows to perch on any of the neighbouring trees. At this moment a travel-worn crow, which rested for a moment on a forbidden tree in mere ignorance, is catching it from the indomitable little tyrant and his wife. Each in turn, with torrents of contemptuous abuse, drops into him from a height of twenty feet, then wheels round and 
is ready again. The crow holds his ground from sheer cowardice rather than obstinacy, and twists his neck in vain efforts to present an open beak at the point of attack. At last he overbalances himself and hangs by his feet for a moment in utter despair, then flies for his life. With a derisive yell, the victor makes one last descent into his back, as if it would transfix him, then returns slowly to the tree, panting but triumphant. While the Butcher Bird and the King-crow are defying their enemies, the tiny Sunbird is outwitting them. It has sclected a dirty-looking tree, literally alive with bloodthirsty red ants. At the very end of a waving branch it has hung a neat little purse, with a small hole on one side, near the top, and a

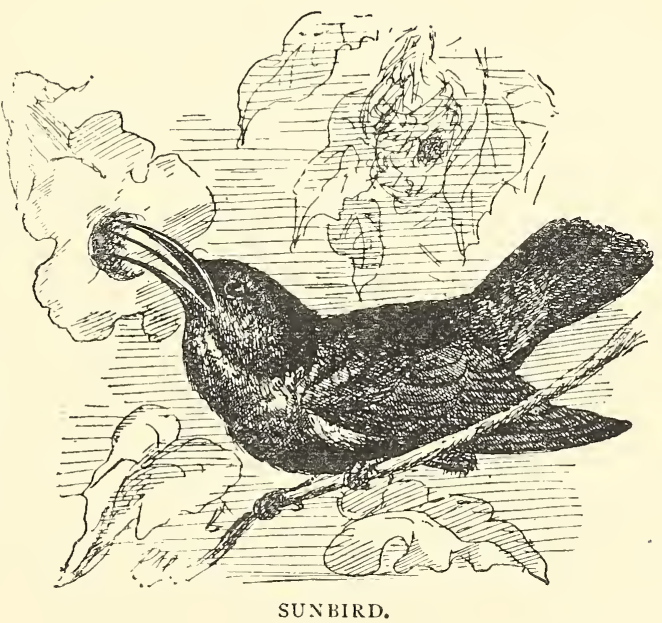
porch to keep out sun and rain. The lining is of cotton 
from the silk cotton tree, warm and smooth. When comfort has been provided for, the work of external decoration begins. First the whole outside is draped with shreds of spiders' webs. Whether this is done to discourage the red ants I cannot say; but it serves another purpose, for now the bird goes about collecting any rubbish it can find and sticking it on the glutinous web. Old scraps of moss, spiders' egg-cases, rags of white silk from the nests of the red ants, and above all, the sawdust and refuse which woodboring caterpillars shovel out of their holes, are gathered together and stuck on anyhow, till the outside of the little house is as thoroughly disreputable as art can make it. Then it is ready for occupation. Lizards cannot get into it, crows do not suspect what it is, and if they did, would not know what to do with it. The very squirrel is baffled. And now note the way the bird behaves. $\mathrm{He}$ is skipping about in the highest spirits, spreading his tail and flapping his wings, singing snatches of an old glee, hovering over a flower while his long tongue searches its recesses, or peering about a dirty bunch of cobweb for little spiders. Suddenly he appears to notice that bunch hanging at the end of a branch. He flies straight to it, clings to 
the side with his feet, and thrusts his head into the hole at the side for a moment, then darts away again as if saying to himself, "No spiders there." But he gave her a kiss

Take another instance of fraudulent simplicity suggested by the loud kee-ko of the Crested Swift as he sails about in the sky overhead, or perches on that dead tree, with his crest up and that $\mathrm{jaunty}$ air which fits him so well. I am certain where his

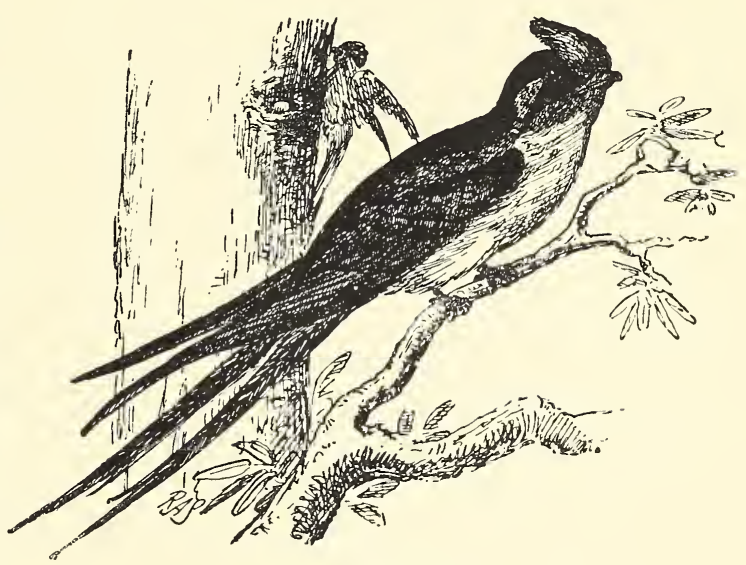
CRESTED SWIFT.

nest is: it is on that same dead tree without one leaf to conceal it; but for my life I cannot find it. The difficulty is that there is nothing to find; not a straw, or a fibre, or a scrap of moss has the bird collected lie simply spat hard on the same spot from day to day. As a voluminous spitter he 
could give points to any Kentucky man, and the result was a sun-dried lump very like the little brown fungus which grows on old trees in the rainy season. It is not the size of a rupee, and from below is scarcely visible-certainly not distinguishable from any of the numerous warts and lumps which disfigure the old tree; but it holds one egg safely and is firm enough to support the handsome bird which sits patiently over it in the blazing sun of noon and the dew of night. Now, why should the Sunbird or the Crested Swift require to practise such arts when the dove and the bulbul get on without them? The silly dove arranges a few twigs in a cactus bush and lays her eggs on them. If you pass by she dashes off in such a flutter that you cannot help looking up to see what is the matter, and there the eggs are, shining through the structure of the flimsy nest. It is a mystery; but there is this difference between the egg of the Crested Swift and the egg of the dove-that the former is a precious thing destined to produce a Crested Swift, while the latter will come to nothing but a silly dove, with just intellect enough to find its food and grow fat for somebody to eat. And that which is precious is scarce. There is only one egg of the Crested Swift, and 
there will not be another for a twelvemonth; but the eggs of the dove are as plentiful as they are cheap. All the year round she is making her foolish nests, and if one comes to grief and one prospers, she will still multiply much faster than the Crested Swift. So with the simpleminded Bulbul; its function in nature appears to be the same as that of the hens in my yard-namely, to lay eggs for others to eat. Every second nest at least meets with an accident, but a merry heart doeth good like a medicine, and the Bulbul is always merry. When one nest is destroyed she just makes another and lays a few more eggs. If the first fails, the second may succeed, and if the second fails, the third may succeed; and so, by paying tribute to their enemies, the Bulbuls still contrive to multiply, and keep every garden, grove, and hillside lively with their twitter.

Thus, one in one way and one in another, one by force and one by fraud, one by resistance and one by submission, they keep their place in the great struggle, and it is curious to note how the ways and instincts of each fit in with the course which it has taken. Birds which build in high trees have no special fear of man, and those which make their nests in holes disregard him altogether. The 
Coppersmith will hammer away at a branch just over the door of your tent, caring nothing who sees her. She has only one enemy, the snake, and if it finds her house, neither cunning nor courage will avail anything. But birds that make their nests on the ground fear man above all things. There is a little kind of Robin, or Chat, a dapper little bird in black and white, which makes its neat nest under the shelter of a stone, or at the root of a bush. How often I have had a contest of patience with that bird and gone away beaten! "Oh!" it seemed to say, "you want to find my nest, do you? I haven't one." And, with a grasshopper in its mouth, it perched on a bush, jerking its tail pleasantly and saying tea in a tone which I knew was meant as a warning to its wife and little ones. In vain I sat and tried to look innocent till I was tired, or got up and seemed to walk away, looking over my shoulder as I went. Still it sat and said tec. I got behind a bush and peeped cautiously through the leaves. It saw me and said tea. As soon as I was really away, it would fly straight to its little brood and comfort them with the grasshopper. Of all devices by which birds have sought to secure the safety of their little ones, I think the stranğest and most ingenious is that of the Red 
Woodpecker. I cannot forget the feelings with which I first saw it digging its hole, not in bough or trunk, but in the great, brown nests of the vicious little tree-ant. How it gets rid of the occupants, or whether it makes terms with them, I cannot say. It keeps its secret to itself and lives, I should think, in perfect security, for no enemy is likely to come prying about those nests.

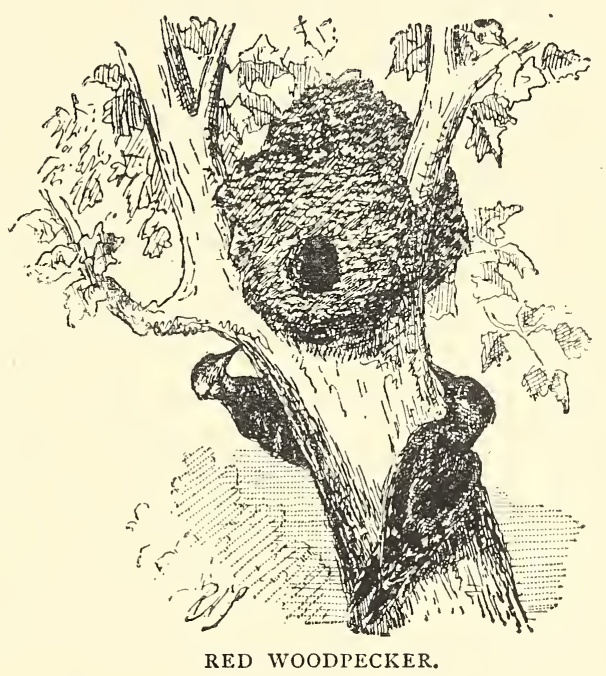

Ruminating on these things and wandering on, I noticed a great dark bird sailing over a wooded hillside, and from the blackness of its ample wings I knew it must be the Black Eagle. A rare bird it is, and noble to look at; but how debased! By lineage it is an eagle and by trade a poacher. Dr. Jerdon says: "It lives almost exclusively, I believe, by robbing birds' nests, devouring both the eggs 
and the young ones." For a moment there flashed on me the gleam of a hope that its nest might be in that clump of tall, dark trees. "What a prize its eggs would be!" I asked some country bumpkins, who were working in the fields, where they thought its nest might be ; but they did not appear to see much reason to suppose that it indulged in the habit of making nests, or laying eggs. So I sat down and watched it, and very soon I saw that it was on the same errand as myself-viz., bird-nesting. Methodically it traversed the whole side of the hill, sailing low and scanning every bush and tree; then crossed the little valley in which I was standing, to beat the hill on the opposite side. Suddenly it stopped, circled quickly round a small tree and plunged into it legs foremost, as eagles always do except in pictures. It evidently missed its quarry, for it rose again, but it plunged once more into the tree and remained there. With the thermometer at $90^{\circ}$ in the shade (and what in the sun!), I ran for that tree, thinking involuntarily of Falstaff larding the lean earth as he went along; but before I could get there, the eagle rose majestically and sailed away. Pushing the branches aside and looking in, I found a Bulbul's nest, with some eggshells and a spilt yolk, and at the foot of 
the tree were two feathers from a Bulbul's tail. At his first plunge he had tried to catch the sitting bird, but, like Tam o' Shanter's mare, it escaped with the loss of its tail. Then he sat down to breakfast on the eggs, with an eagle's beak for his spoon. It is no wonder that he could not eat them cleanly; and, indeed, it is one of the strangest things $I$ know in nature that a bird so armed and equipped should feed on eggs. But it was not to feed on eggs that he was so armed and equipped. I feel sure that the Black Eagle furnishes an example of very recent degeneracy. This is an intensely interesting subject, but too large a one to enter upon to-day.

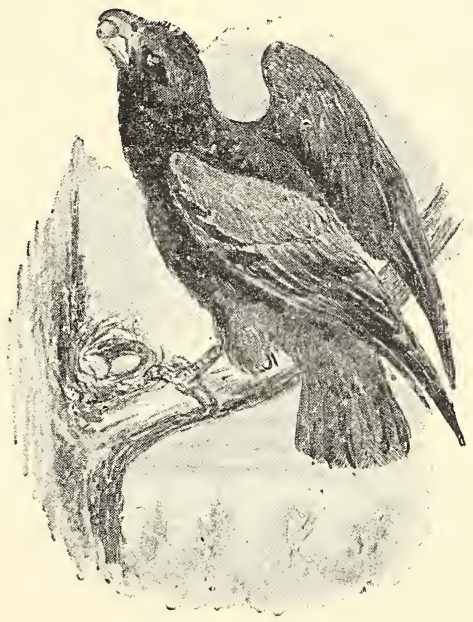

BLACK EAGLE. 


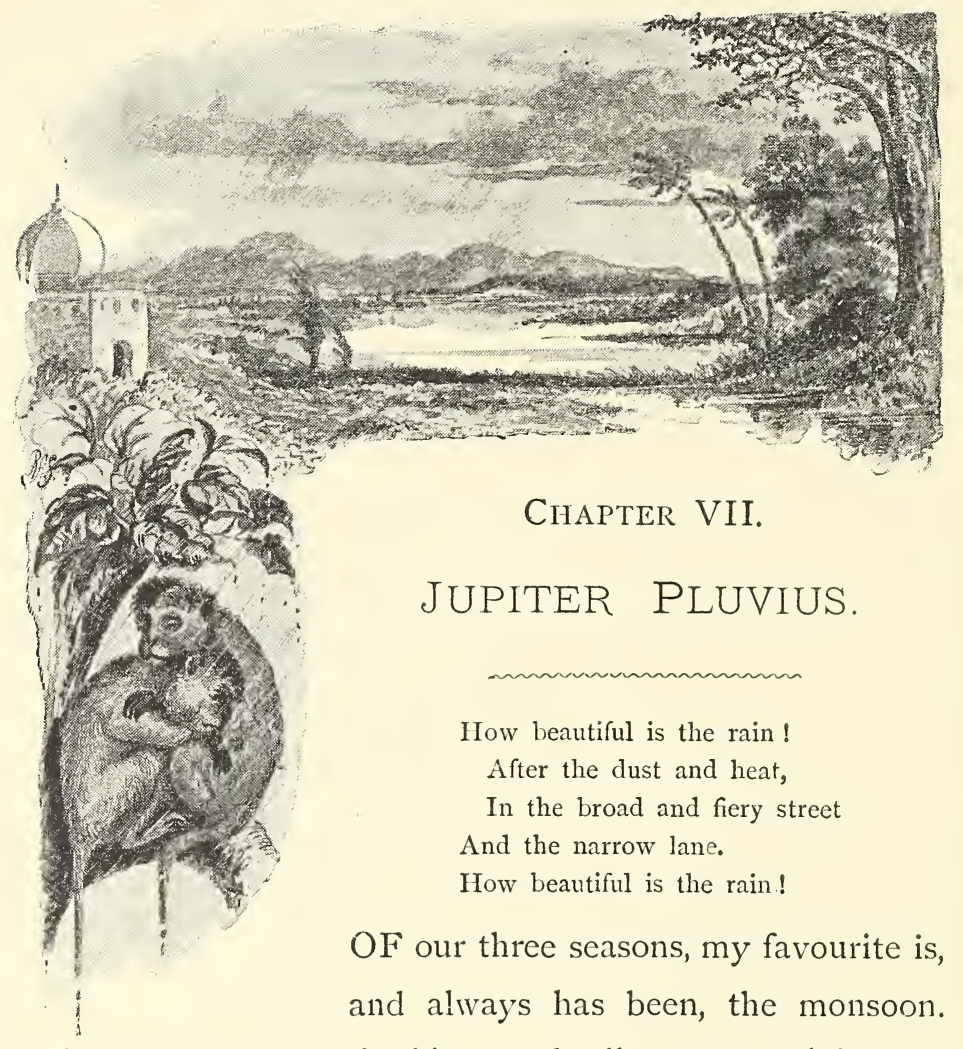

It is the time of refreshing, and all nature rejoices in it, and I rejoice with nature. What the spring is to northern latitudes, the monsoon is to us. I do not mean that spring has no place in the Indian calendar. That mysterious influence which comes with the returning sun, 
and, undiscerned by eye or ear, awakens the earth, visits us too. Then

$$
\text { "The wanton lapwing gets himself another crest," }
$$

and if a fuller crimson does not come upon the robin's breast, it is because in this country that is not the region in which his crimson is situated; but he and the other birds break out into song and begin to build their nests, the trees bud, and many gay butterflies awaken to life. But in our spring-tide vivifying heat is divorced from refreshing moisture, so that half nature, instead of being warmed to life, is scorched to death. True, the Banian tree, whose roots reach down into the secret chambers of the earth, comes out in bright array, and the Mango buds. and blooms; but the grass, packed in dust above and below, cannot rouse itself to the call of spring, and the fields grow only more dusty and more dry. Our spirits are like the grass and seem to be packed in dust. The cattle wander about like shadows and grow visibly leaner every day, envying the serpent for the curse that lies on him. He only of living things has enough and to spare. So I say, our true spring, the beginning of our year; the birthday of nature, is not in March, but in June. Let it be ushered in with salvoes of artillery and a carnival of the 
elements, or let it leak in silently during the night and greet us in the morning, the effect is the same. The leaves of the trees are washed, the dust on the roads is laid, and the spirits of man and beast participate in the baptism.

Scarcely has the earth sent up the incense of its gratitude to heaven when a thousard activities are awakened within it of which we shall soon see the outward signs.

In the halls of the White Ant there is eager excitement, for the young queens of the future, in their long and gauzy wings, like bridal veils, are crowding to the door, and as each one starts on her long and hazardous journey in quest of a new home, friends press round with the blessing of Rebekhah:- "Be thou the mother of thousands of millions, and may thy seed possess the gate of those which hate them."

There is joy above ground too, for the Crow and the Kite, the King-crow, the Lizard, the little Owl and the Bat have gathered to the feast. No deduction need be made from the joy of the White Ants on account of the joy of the birds which have come together to feed on them, for those which escape know nothing about it, and those which are eaten know less; so happiness reigns on all hands. Within a few days of the first rain the air is full of Dragon 
Flies, crossing and re-crossing, poised motionless for a moment, then darting away with that mingled grace and power which among the winged things of this world is, I think, unmatched. Where they come from I cannot tell, but any one may read the meaning of their presence in the air. Dragon-flies are the swallows of the insect world, and their prey is the Mosquito, the Gnat, the Midge, the Fly of every size and hue. These swarms, therefore, tell us that the moistened surface of the ground, with its mouldering leaves and sodden grass, its mouldy bark and decaying refuse, has become one vast incubator teeming with every form of ephemeral life. Many another indication of the same kind will catch the observant eye.

Talkative Mynas in pairs are pacing the ground, for among the sprouting grass they will find the lubberly sons of the Grasshopper. Acridotheres, the grasshopper-hunter, is the happiest of ornithological names; but I never could understand why it should be called tristis. Who ever saw a sad Myna? Crows also in twos and threes are taking an interest in something, and for once I am in charity even with them.

The roadside rivulets are full of little Fishes, arrived from I know not where, to grow fat on the Earthworm and 
the Mole Cricket borne helplessly along by the sweeping flood. When night comes on, great Moths fly past, and "the Beetle wheels his droning flight." The Fireflies also light their lamps and hold their silent concerts, the occupants of each tree flashing in unison and making sheet lightning in the woods. And what shall I say of the garden Bugs on the dinner table and the Blister Beetles and the squeaking Green Crickets? And what of the Musk-rats which come in to eat them?

This is par excellence the season for rambling abroad. At every turn there is something new to see. Out of earth and rock and leafless bough the magic touch of the monsoon has brought life and greenness. You can almost see the broad-leaved vines grow and the twining creepers work their snaky way, linking tree to tree and binding branch to branch.

But nothing lives for itself alone. All this luxuriance of tender foliage has scarcely appeared when the Caterpillar is ready to eat it, for the Butterfly had laid her eggs on the naked branch before the leaves were out. Green Crickets, too, with insatiable appetites, are under the leaves, trying not to be seen, and birds with hungry families are hunting for them. Leaf 
Insects and Stick Insects are trying to cheat death by quaint disguises, and fierce Mantises are using disguises as strange that they may compass the death of others. The Mantis and the Phasma, or stick insect, are very interesting in their relation to each other and strike me

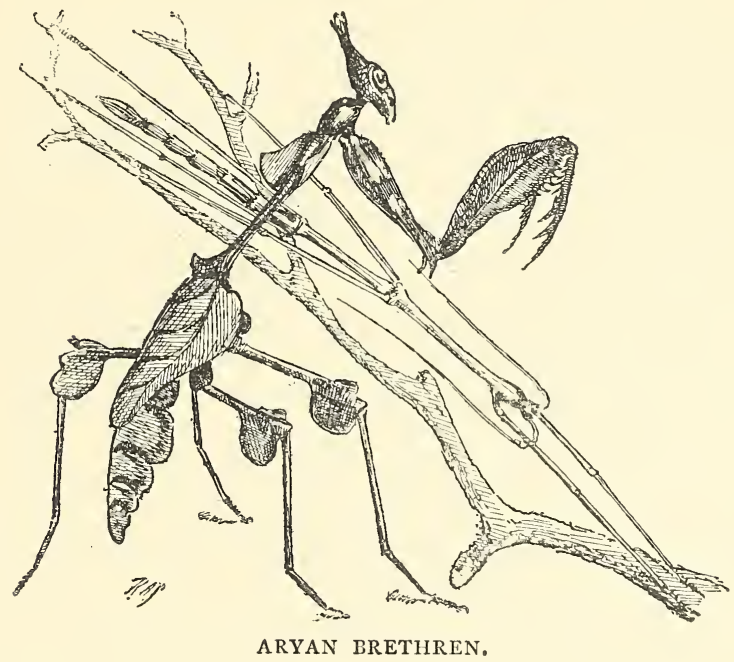

as apt symbols of us and our Aryan brother. They are plainly of the same stock, and, as an evolutionist would say, have had a common ancestor; but on what widely divergent lines have they developed! The Mantis feeds on flesh, his hands are weapons of war, and his life 
is one of rapine and bloodshed. The Phasma is a vegetarian, his meek extended arms are emblems of submission, and he seeks safety by instinct in the practice of dissimilation. Each is happy, I doubt not, in his own way, widely different as those ways are.

I know that the word "happy" in this sense will be objected to by a certain school of men of science. Professor Huxley, for example, says it is quite an open question whether a crayfish possesses consciousness or not, and that nothing short of being a crayfish would give us positive assurance on the point. The more thoroughgoing Brahmin maintains that the crayfish itself is maya, an illusion, existing only in the mind of the professor who thinks he is dissecting it. I cannot upset either argument, as I cannot upset a billiard ball, and perhaps for the same reason, viz., that it stands on no base; so I let them roll on, and for myself elect to believe that all the living things I see about me, each in its own measure and according to its own capacity, are happy, enjoying their powers in the exercise of them and their wants in the satisfying of them, flling each its own niche in the great temple and desiring nothing beyond, like Hamlet bounded in a nutshell and counting himself a king 
of infinite space; for they have no bad dreams. Man alone, with his

\author{
"obstinate questionings \\ Of sense and outward things,"
}

cannot be altogether happy on these terms. Nevertheless it is good for him to feel their happiness, to mingle with this monsoon luxuriance of life and joy. It is as when David played with his hand upon the harp, and the evil spirit departed from Saul.

There is another feature of the monsoon which has a wonderful charm for me. I mean the clouds. Many Englishmen never throw off the bondage of their old English feelings, and a cloudy day depresses them to the last. Such conservatism is not in me. After the monotony of a fierce sun and a blue sky and a dusky landscape quivering in the dim distance, I cry welcome to the days of mild light and green earth and purple hills coming near in the clear and transparent air. And later on, when the monsoon begins to break up and the hills are dappled with light and shade, and dark islands move across the bright green sea, the effect on my spirits is strangely exhilarating. Why is it that so few of our Indian painters have given us monsoon scenes? 
In candour it must be admitted that the monsoon brings with it some inconveniences; but they are for the most part connected with our civilisation. Books grow limp and their backs come off, leprosy attacks gloves and all manner of silk and satin finery, a marvellous forest of mould springs from the bodies of the tiniest butterflies in my collection, cheroots grow too damp to smoke, rats infest the house, and basins and soup plates stand about on the carpet to catch the drops from the leaky roof. The ants, which stand next to us in point of civilisation, evidently suffer in much the same way. The water has got into their under-ground houses, flooding the cellars and nurseries, wetting their stores of grain and drowning a good number of babies. All day long they are busy repairing or checking the ravages of the flood.

But the prime inconvenience of monsoon weather is independent of civilisation: the fear of getting wet is universal. The gentleman runs because the rain will spoil his clothes, but the coolie runs as fast because he has none. And when you realise that at this time birds of all kinds and the majority of wild beasts, not to speak of flimsy butterflies and moths, live and sleep in the open air, you cannot help wondering how they manage. My sympathies go especi- 
ally with the monkeys. When the pitiless rain is pouring hour after hour, and the water is streaming down the trees, and the branches are all nasty and slimy, and every shake brings down a redoubled shower from the leaves, I wonder where the poor monkeys are and what they are doing. Are they all huddled together, with their heads buried in each other's bosoms, and the water spouting from their long tails?

Many birds, too, lay their eggs during the first and heaviest month of rain, and sit in open nests day and night, pelted with drops almost as big as their heads. It is true that the feathers of birds, oily and smooth and arranged one over another like tiles, with an underlayer of soft, warm down, form a costume for all weather, to which the art of man has never been able to make any approach; and the combination of long hair and short wool which forms the fur of many beasts is nearly as good; but a bird or beast can be wet to the skin when the station doctor is registering ten inches in twenty-four hours.

And what of the bats, Flying Foxes for instance, which hang with their feet up and their heads down? The fur of bats, we know, is different from that of all 
other animals, and forms a most interesting object under the microscope; but what is the advantage of that if it slopes the wrong way for keeping out the rain? It is nothing short of a scandal to Darwinism that bats have not long since reversed their fur.

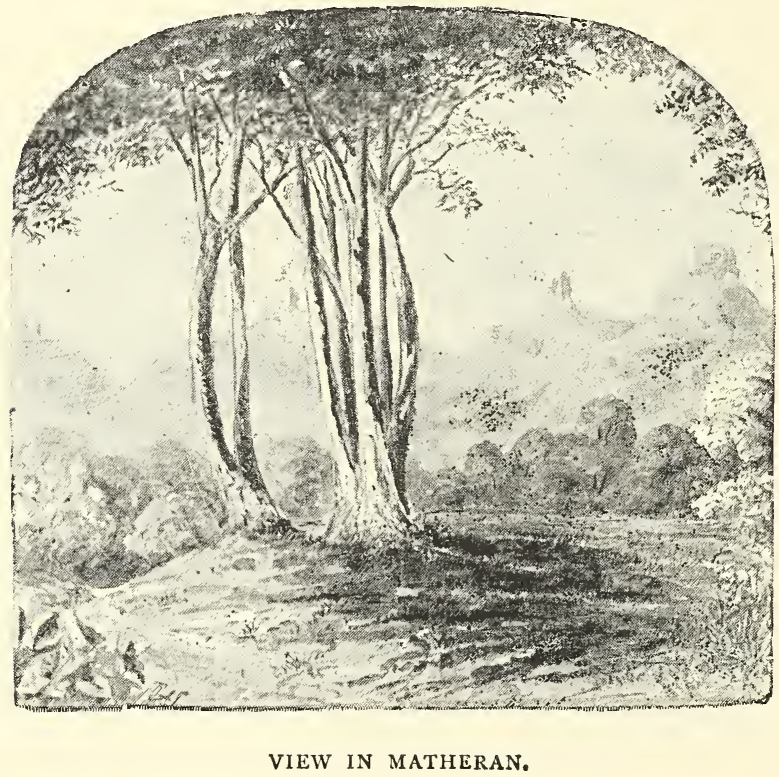




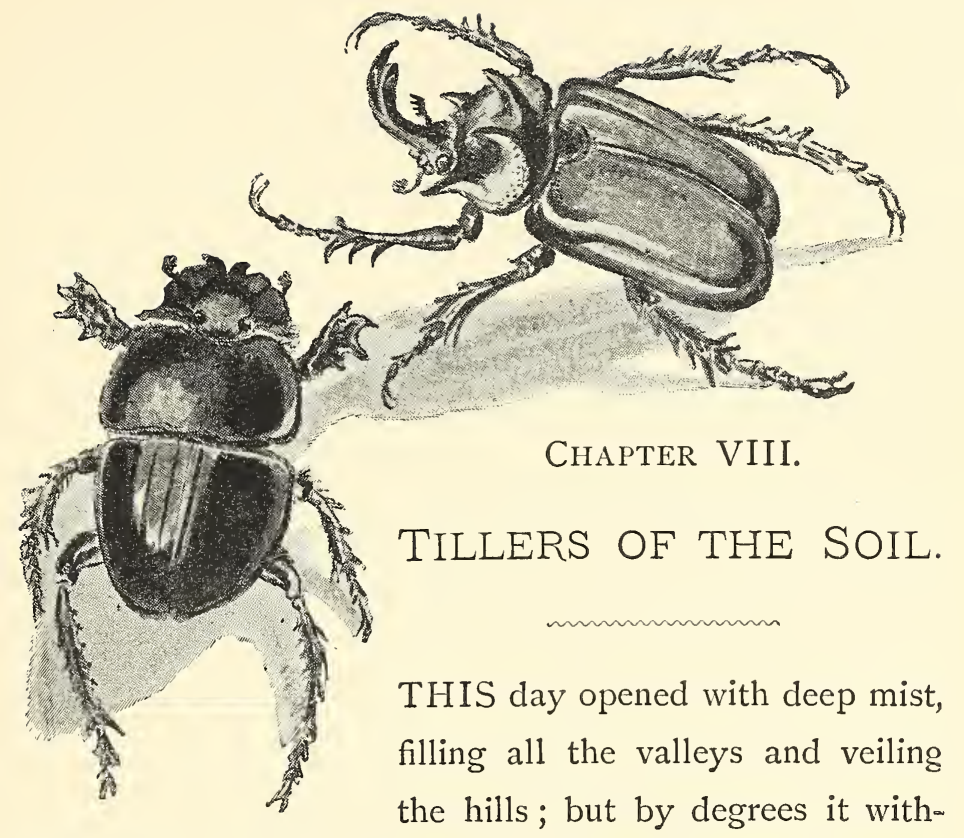

drew, and a cloudy sky and a cool moist breeze invited me out for a long prowl. The first thing that caught my eye was a very common thing on Indian roads, and a vulgar thing, not to be mentioned by name among us, though to the Hindoos it is in a manner sacred. But the naturalist, like the farmer, must not be proud.

"Ne saturare fimo pingui pudeat sola," \&c.

So I stooped down to note this little cumulus fimi pinguis, for there was one thing about it worthy to be 
noted, and that was that half of it appeared to have been transformed by some process into dry earth. When the ground and everything else is moist with recent rain, a pile of dry earth is a phenomenon and needs some explanation, but I had only to kick it aside with my foot to get that. The ground underneath was like an Irishman's definition of a net, "a collection of holes," and in each hole there was a round, bullet-like beetle, solemnly burrowing downwards and throwing up the earth behind it. As the earth came up, the manure went down to supply its place. Very shortly there will be nothing above ground but a pile of earth, and then each beetle, having left an egg in its hole, will withdraw, and, after many days, when all traces of the work have been washed away or trodden down, men will pass up and down the road, little thinking that far under their feet a score or more of loathly white grubs are wriggling and growing, each in the midst of a noisome mess of - well, nourishment. These beetles are all of one great tamily, or tribe, but some are black and some are brown, and some are large and some are small.

A few days ago I caught a very Goliath of them busy at the same work, making a hole that would have 
offered roomy quarters to a mouse. I bottled it and brought it home, and it is before me now. Its head and front parts are black and not smooth, but finely grained, while its elytra, or wing cases, are of a shining maroon colour. Its head is quite flat and serves it for a spade, while its fore-arm is much flattened too, and furnished on one side with three great teeth, so that it forms a pick and shovel in one. Its curious antennæ are tucked away under the head shield, and its eyes are, so to speak, behind the shoulder of

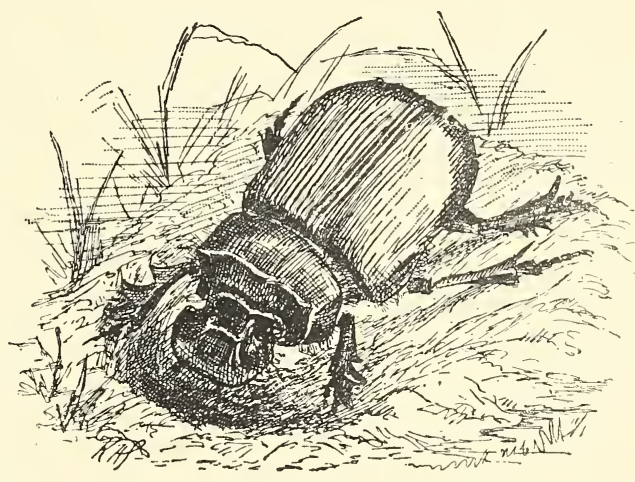
the spade, out of the way of harm. When it digs, the stout fore-arms work sideways, tearing up the hard ground; then the spade is thrust in and lifts the loosened soil. Its hind legs are flattened too and serve to shovel the earth away behind it. Some of the family have an upright horn on the head or nose. This is, without doubt, an example of "protective mimicry." 
The enemies of the beetle (collectors, for instance) are terrified by its resemblance to a rhinoceros, and before they recover from their astonishment the beetle makes its escape. N.B.-This is ironical.

However, for practical work I prefer the simple spade, and I would back my navvy against any that the world has produced. What thighs he has! I believe, if you sat upon him, he could almost walk away with you, but of course he might prefer to burrow into you. In truth the strength of these burrowing beetles is incredible. When they come to my lamp and tumble about the table-cloth, as the smaller kinds often do on a rainy evening, I sometimes amuse myself by putting a dinner plate on the back of one of them. For a few seconds it lies still, wondering what has happened, but presently it bows itself, like Samson, and the plate is heaved up and moves away as easily as the gates of Gaza. You may easily recognise the family by the heavy build, the flat head, and the unmistakable burrowing tools, and as they blunder about the table-cloth, looking so clean and bright, it is curious to think of the work from which they have come. They often try to fly, but cannot get under way at all, and only tumble over on their backs. To effect 
a successful fight, a beetle must have fair way and no lamp to puzzle it. Then it will lift its hard wing covers, unfurl its wide wings, and go off in a straight course, like a good ship before the wind, with a humming noise, which, no doubt, keeps up its spirit like a bagpipe.

There is another group of these beetles which, when they have found a store of manure, make round balls of it, which are rolled away to a distance where a pit has been dug to receive them. I have often found these at their task, and "exhilarated myself," to borrow a phrase from a German friend, by watching the droll operation. Her forelegs being burrowing tools and unfitted for any other work, the beetle finds that her best plan is to stand on her head and kick the ball along with her hind feet. It is bigger than herself and rather unmanageable, so it rolls this way and that way, but she runs round and round it on her head, kicking furiously, until she has got it into the vicinity of her pit. Then she leaves it and goes to look for the exact spot. When she returns she finds that another beetle has found the ball and appropriated it, and then ensues a fierce struggle for possession. It is a curious kind of fight, for both are thoroughly armed for defence, but neither has any sort 
of weapon with which the other may be hurt. Under these conditions a very high degree of courage is possible, and the frantic valour of these beetles affords quite a spectacle. How they bump against each other and hustle each other! Then they get on opposite sides of the ball, and each tries to roll it her own way. But the usurper is fresh, while the rightful owner is wearied with toil, so she gives in at last and walks slowly away, a sense of wrong rankling in her bosom. But there is no appeal for her against the law-

"That he should take who has the power, And he should keep who can."

She will right herself, no doubt, by plundering some weaker beetle. But sometimes a better spirit prevails, and two or three beetles enter into partnership to roll a joint ball. Then you shall see a ball indeed.

It is intensely interesting to watch these little creatures toiling so industriously to make provision for their children, which will never know them or requite their care. But there is a far deeper interest in the thing. Soar above the individual beetle and its private ends, and contemplate all the myriads of beetles scattered over the face of the country, working together to carry out a great 
purpose which never comes within the scope of their personal aims. What is it they are doing? They are tilling the ground. These jungles are as all the face of the earth was when Adam was still uncreated and there was not a man to till the ground. As then, so now, there often comes up a mist which waters the earth. But that is not enough. The ground must be ploughed, that that which is upon the top may go down and that which is below may come up.

The opposite process is for ever going on, Every tree is silently but ceaselessly at work, thrusting its roots, like fingers, down into the earth, and separating and drawing up certain constituents of the soil, and conveying them through the channels of the trunk out to the ends of the branches and moulding them into leaves. The leaves will wither and fall to the ground; or else cattle will eat them, or insects will feed upon them; but they too will die and fall to the ground.

Thus certain elements of the earth are for ever being brought up from the depths and laid upon the surface. This cannot continue. They must be taken down again and restored to the soil, or the foliage of the forest will soon fail and the earth will be barren as the moon. To 
carry out this great work there must be workmen, and millions upon millions there are, working as silently and as ceaselessly as the trees.

You may think that the little beetles are insignificant and their labours not to be taken into account. But they are not insignificant. They are small, but they are strong in their numbers, and wherever I wander, I see proof that they are sufficient for all the work that there is to be done in their own line.

Of course there are other departments, and each has its own staff. When the old tree falls, there are wood-boring beetles, with their strong jaws, ready to bore it through and through and turn it into powder. If a field-rat dies, there are beetles at hand to dig its grave and say, "Dust to dust." The leaves are entrusted to the earthworms which we see drawing their lean length out of every clod that we turn up in our gardens. And from the beginning of the world till now we have been content to believe that these creatures were without use, unsightly superfluities in the order of nature. But Darwin came, with eyes to see, and lo! they are not superfluities at all, but quite indispensable, a countless gang of laborious workmen, appointed to take the dead leaves to the place 
whence they came and convert them into soil again that the earth may be green.

And I have advanced upon Darwin (modestly I say it), for I have discovered that they have overseers set over them. These are the crows which we see patrolling meadows and fields after rain. We say familiarly that they are "looking for worms," and we are right. For the worms would grow lazy and live on the surface of the ground, eating the leaves where they found them; but their taskmasters are ever on the watch, and if they are caught the penalty is death; therefore they are forced to live in the bowels of the earth (pregnant phrase!), and to come up at night and draw the leaves down.

But in this country there is a workman in whose presence even the earthworms must "hide their diminished heads." Darwin never had the chance of intimacy with the white ant, but Professor Drummond fell in with it in "Equatorial Africa," and his eyes were opened. Our eyes too have long been open upon the white ant, but with a kind of squint in them, or a moral myopia; for we are mostly like the burrowing beetle, intent upon our personal aims, but as "impercipient" as Baboo Onocool Chunder with respect to the great world spinning for ever down 
the ringing grooves of change. So we judged it by its occasional blunders. When it failed to see the distinction between a wooden box and a dead tree, when it took in hand to convert the vegetable tissue of our books into soil, we saw and cursed it. But its stupendous work for the weal of the world went on all around us, and it never came into our minds to bless it. Is there any other such work going on in the world? Withered leaves, old wood, dead bark, every used-up product of vegetable life is taken to pieces and carried off along wonderful covered ways and through underground channels to the workshops below. "To be eaten," you will say. Yes, to be eaten. But eating does not annihilate matter. The eaters live and die underground, and nothing that goes down into those cellars comes up again until it comes in the sap of the trees to make the foliage of the forest.

All this is true, beautifully true, and yet-I also am human-I cannot myself exorcise the old feeling about the white ant. Whenever I see a great anthill dug to the foundations by a bear, and note that the savage epicure did not stop till he had found the chamber of the fat queen and sucked her down like an oyster, a genial sense of satisfaction wells up within me from some 
underground spring. I stamp upon it of course, and exercise myself at once in sentiments of pity for the peaceful and industrious community so ruthlessly extirpated; and so my virtue is of the right sort, a robust exercise of the will and not a mere outflow of shallow feeling. But I wish it did not give me so much pleasure

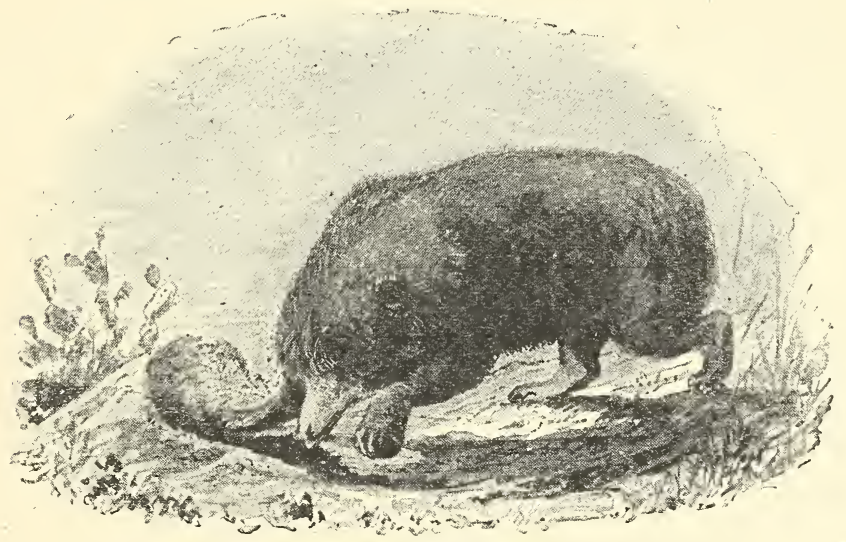

A SAVAGE EPICURE.

to recall a discovery I made some years ago. I was living in a bungalow with a large garden and a tennis lawn. In the foundation of the bungalow there flourished a populous community of Lobopelta. Lobopelta is one of the military ants, which go out in armed bands, ravaging the country and slaying every living thing that they 
can overpower. I have seen a ferocious centipede fighting for its life among them with little hope of escape, and I have often seen them dragging home the carcases of large earthworms. I have also welcomed their raids upon my book boxes, where they massacred the crickets and cockroaches in a way that was refreshing. But it was not till last year that I discovered what I have proved abundantly since, that their very staff of life is the white ant. The community I have mentioned lived in the foundation of my bungalow. They generally do live in the foundations of bungalows, and a naturalist who will buy a bungalow for the sake of digging them out is a great desideratum, for the queen of the Lobopeltas has never been found and their inner life is a mystery. Their outer life is no mystery, but I never had such an opportunity of observing it as I had at the time to which I allude. Every evening about sunset they would issue from their main gate in column, two or three abreast, as their manner is when on the march. The column might be twenty or thirty yards in length. Scouts went ahead and scoured the tennis ground, where the turf was withering as the hot season advanced, and white ants came up nightly to eat it. Presently some of the scouts found one of those 
familiar pie crusts which white ants build over themselves before they dare begin to work, and with eager haste they brought the news to the main column. The effect was wonderful. The word ran along the ranks, every ant doubled its pace, and the martial column became like a crowd rushing to the scene of a great fire in the city. These ants, under excitement, are very human. "The rabblement shout and clap their chapped hands, and throw up their sweaty nightcaps" just as if they were in Hyde Park. I have not seen the nightcaps, but I have often heard the shout. Well, when they reached the earthworks of the termites, they formed in a dense squadron and waited in silence till darkness set in. Whether they want strength or intelligence to break through the earthy crust I cannot say, but as the white ants cannot extend their work without making a break at some point in their defences, their enemies may have been waiting for this opportunity to rush in. All I know is that at sunrise, next morning, the slain were literally lying heaps upon heaps, and the soldiery were hurrying to and fro to get them all gathered in before the sun should get too hot for outdoor work. It was a ghastly spectacle, and I gloated over it! 
The burrowing beetle too has its enemies. Early in the morning I often come upon the large Stripe-necked Mungoose (Herpestes vitticollis) wandering about open patches in the forest, where cattle are wont to graze. Every now and then he stops, digs fiercely and pulls out something, which he crunches as a wicked boy crunches sugar-plums. He is in a suit of "pepper and salt," with a black stripe across his neck, and his fine rust-coloured tail is tipped with black, and very handsome he looks. But I am on the side of the beetle. Yet the mungoose also is appointed, I doubt not, to his stern office. The beetle will learn to dig deeper next time!

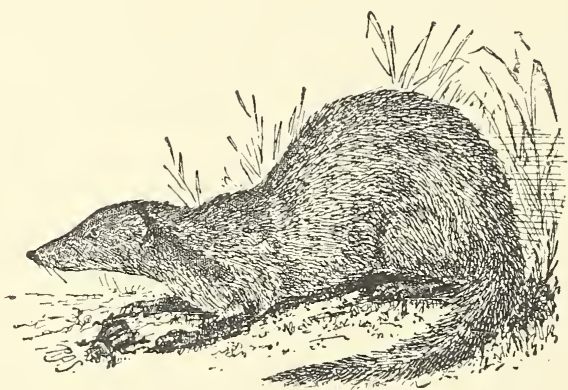

MUNGOOSE, 


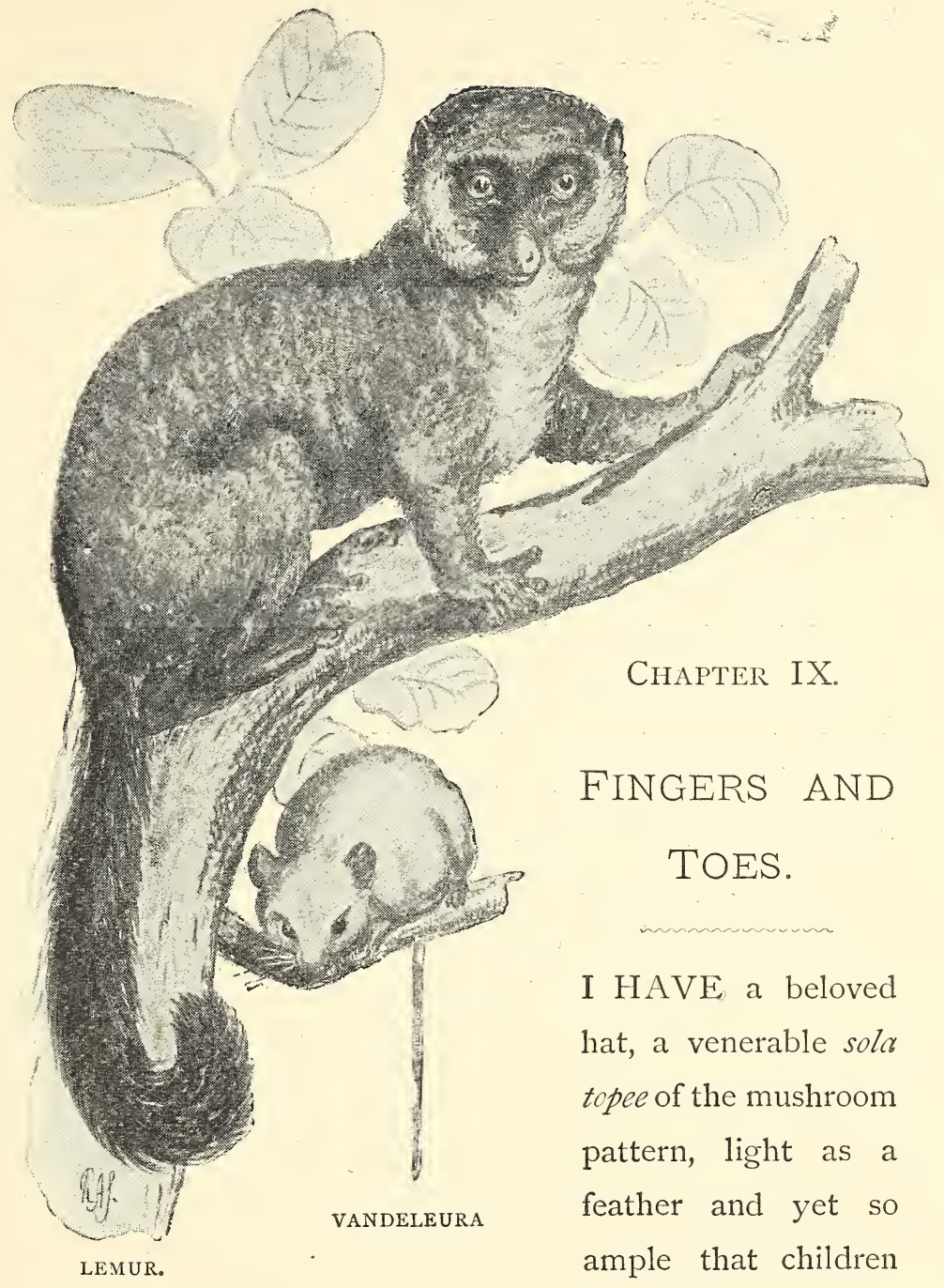

might play in the shade which it casts all round me, 
It has seen long service, and now rests, an aged pensioner, on a solitary peg on the wall of my verandah; but one sunny day some weeks ago I remembered my old favourite, and taking it kindly off its peg, put it on my head. Almost immediately I felt something scrambling and pushing its way among my hair. "A gigantic cockroach," I said to myself. "Now it shall not escape." So I quietly removed my hat. A beautiful mouse slid down my neck and began travelling along my arm. It was of a light fawn colour above, but all the under parts were as white as snow. Its feet were pink, it eyes large and soft, and its tail as long as a bit of string. It showed complete selfpossession as it clambered about my coat, trying to find a way out of the strange country into which it had got. It was not quite sure that the whole thing was not a dream. I called for a cage and easily guided the perplexed little beast into it, for he was a "Long-tailed Field Mouse," and I wanted to examine his nails. A great deal hangs on the nails of this mouse. By virtue of them it is not now Mus oleraceus, as Jerdon called it, but Vandeleura oleracea, having been promoted to a sort of peerage among mice. The difference between it and a Mus, or vulgar mouse, is this, that whereas Mus has nails 
on its thumbs and claws on all its other fingers, $V$ andeleura has a delicate little nail on both the thumb and the little finger of each of its four dainty hands-for I would not call them feet.

Now the difference between a "claw" and a "nail" is a very radical difference. A "claw" is a horny point to a toe, like the iron with which a walking-stick is shod. It is good for poking and scratching. When good Dr. Watts wrote,

\section{"Those little hands were never made}

To tear each other's eyes,"

he meant to teach children that they ought not to revert to an instinct which belongs to the time when we wore long, crooked talons. But perhaps he was not a Darwinite. Anyway, he had looked lovingly into the mystery of those little hands, with their expanded and sensitive finger tips, shielded only with soft transparent nails. Those nails are tokens of fingers, not toes, and a finger is not a weapon, but an instrument endowed with manifold fitness for cunning work. It is a perceiving organ also, working with the eye and ear to bring us intelligence of the world in which we live. True, we have nails and not claws upon what we call our toes, but remember that we are altogether 
artificial, and have already confessed that there is something wrong by putting on boots. It needs no argument to prove that in the course of time our toe-nails must entirely disappear. After that, I suppose, our toes will disappear also, or else grow together, so that our feet will acquire that elegant shape which fashionable shoemakers have already sketched out for them. Even now a European foot is a subject for the philosopher and moralist, not for the naturalist. The naturalist must occupy himself with what is natural. Therefore I dismiss the human toe-nail as irrelevant.

Monkeys, I take it, are still within the bounds of the natural, though their sad and dreary eyes seem to be ever scanning the prospect of the next evolution. Monkeys have nails, and so have lemurs and all animals, I think, which grasp with their hands and climb trees.

I once had a tame lemur and used often to take his soft hand in mine and look at his pretty nails. Like a monkey, he had four hands and no feet, but on the forefinger of each hind hand there was a long, sharp claw instead of a nail. On the thumb and the other three fingers there were nails. This curious arrangement puzzled me for a long time, but there is a reason for everything, and 
one day a flea showed me the use of that solitary claw by biting my lemur in the ribs. Poor little beast! I daresay he often had reason to be thankful that nature spared one toe when she promoted him to the order of four-handed mammals.

I never had a more charming little pet than that lemur. He took life so gaily and his antics were so original. When I let him out of his cage in the morning, he would scamper straight into my bedroom and look round, his large eyes brimming over with a mild curiosity. As lightly as an india-rubber ball he would spring from the ground and alight upon my table. When he had examined everything there, feeling it with his fingers, he would bound across to my bed and run up the post and along the top bar. Another airy bound would land him on my shoulders, where he would sit and handle my ears gently, then wonder what was in that hole, and thrust in his long tongue to find out. This was too much for human endurance, so I would roll him up into a ball, wind his long, furry tail round him, and fling him into my bed; but he unwound himself in a moment and skipped away to explore something new. His hind legs being longer than his forelegs, he walked slowly, with his head 
down; but when he was in a hurry, he would stand up and go bounding along like a kangaroo, with his tail in the air, his arms extended, and all his fingers spread, looking like nothing I ever saw. A friend assured me that he was exactly like the devil, which may be, but Lemur

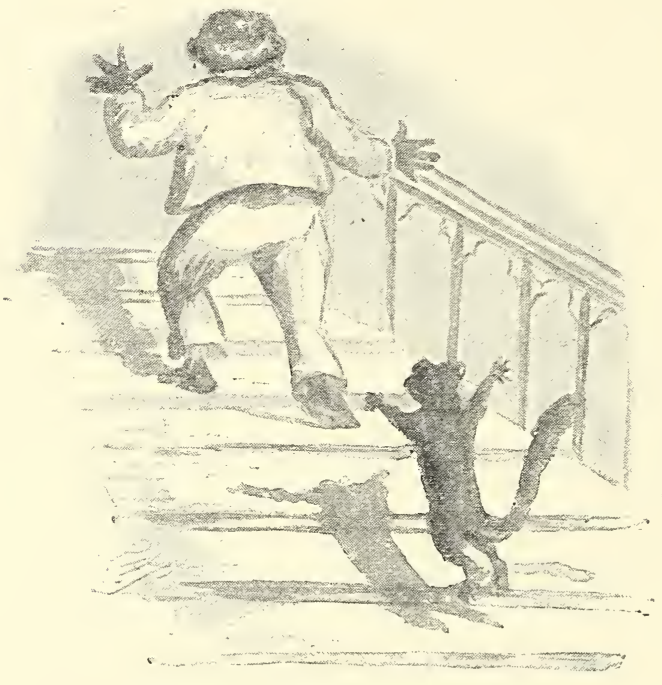

A GLeEFul LiTtLe DEMuN. meansa ghost, or shade of one departed. The servants, one and all, regarded him as a bhoot and fled at his approach. He gave chase, of course, and there was never finer sport than to see the fat butler in full flight up a long staircase, with the gleeful little demon after him, clearing three steps at a bound. But I have wandered a good way from my Long-tailed Mouse. You will see that there is a sort of connection 
between his special endowment of nails and that skill in climbing which enabled him to get at my hat hanging upon a peg in the bare wall. On trees he is more nimble than a squirrel, and puts his powers to villainous uses. I have convicted him of spending his nights running up and down every trellis in the garden, seeking for the growing points of our choicest creepers. Having found them, he eats them, and our choicest creepers do not grow. I have also got circumstantial evidence connecting him with the disappearance of every flower-bud on the largest and handsomest orchid I ever had. A palate educated on such delicacies is of course not to be tempted with bread or cheese, so your traps are set in vain. Each morning reveals some fresh outrage, but the culprit is not found. He is never abroad till darkness sets in, and he rarely enters the house. I doubt if he ever descends to the ground unless compelled. His home is among trees. In the jungles I have often found his nest, a ball of soft grass, in which he feels so comfortable that you may carry away the whole nest in your pocket and he will not leave it.

I have known these his ways for many years, but I was not prepared to find him hollowing out my so'a topee and shredding the pith into stuffing for his sybarite couch. 
And what did I do with him? I let him off. Such is the power of a pretty face. Of course he came back again and brought a friend. I ejected them both, but they returned. Then my patience ran dry. I banished one from the premises and put the other into my travelling spirit jar. But the advantages of my hat as a residence had got noised abroad, and I had to take five mice from first to last out of that relic. By that time they had adapted it so well to their purposes that it was no longer of any use for mine, and I reflected that I might as well have left the first occupant in peace. Weakness is ever cruel, and the weakness called pity is as cruel as any other.

There is another mouse about my premises which you would easily mistake for Vandeleura, except that its tail is only half as long: this is Mus platythrix, the Spiny Mouse. Its distinction lies not in its nails, but in its hair. If you take a lens and examine it, you will find that it is a bijou porcupine. Almost every other hair is a fine spine. For what purpose it is so strangely clothed I cannot tell. Those spines may serve to irritate the mucous membranes of snakes, and warn them not again to eat the Spiny Mouse. Or perhaps they have no use, for their owner has none, I am sure: what mouse 
or rat has any use? They come out when we are in our beds and run about and eat little scraps, and try to keep out of the way of owls and cats, and I hope they do not succeed. Now and then one comes through a window by mistake, and perhaps falls into the bath tub, and I save it from drowning, and so its path crosses mine for the first time. By such accidents I have come to know the Spiny Mouse, but of its ways I know nothing.

About another mouse, or rat, I am in the opposite position: I know its ways, but I never saw itself. It makes its burrow in the forest, on some hill-side, turning out prodigious quantities of earth and pebbles. When it retires for the day it stops up the entrance with stones jambed hard against each other, so that no snake or other enemy can get in. One glance at its arrangements shows that it must be a rat of no ordinary talent and force of character, not to mention mere physical strength. So I determined one day to make its acquaintance.

I took with me two men and a pickaxe, and went to a small hamlet of five or six dwellings, which was not far from my tent. At the door of one there was not less than half a good cartload of earth, and I concluded that 
this must be the abode of the patel, or head rat, of the village. Finding the door closed in the manner I have described, I knew the owner must be in; so I began to dig. We found first a sort of hall or lobby, and from that two passages went different ways. We followed up one which, after much toil, led us to an unfurnished apartment, which appeared to be a boudoir or spare room. We then took up the other passage ard followed it patiently till it led us into the roots of a small tree. We overturned the tree and went on. The passage conducted us straight on into the roots of another tree. We overturned that also and went on. The passage now turned sharp to the right, then to the left, took a downward course, then turned upwards again. We dug on still, removing great stones and cutting through roots of trees. Again the path turned to the left, then to the right, then down, then up and round and round. I tried to lighten the labours of the men with a joke, remarking that the hole no doubt led to the village on the other side of the hill. One of the men saw the joke and laughed, and this unusual circumstance cheered me greatly and I went on. At last we came suddenly to the end of the passage and found-nothing! 
Neither bed nor board was there, nor any sign of a rat ever having occupied the place. Explain it as you may, that was the fact. Perhaps, as we excavated the main passage, some side door leading to the bed chambers got covered with débris and escaped our notice. Or is it possible that the old rat was dead, and the neighbours had mournfully barred the door of the ownerless mansion? Strange things are possible!

It was too late now to trace anything among the ruins, and I had to give up my enterprise. But I measured the ground over which we had gone, and found that we had followed the burrow of that industrious rat for thirty feet. I afterwards set traps, but to no purpose. I am still unacquainted with that rat.

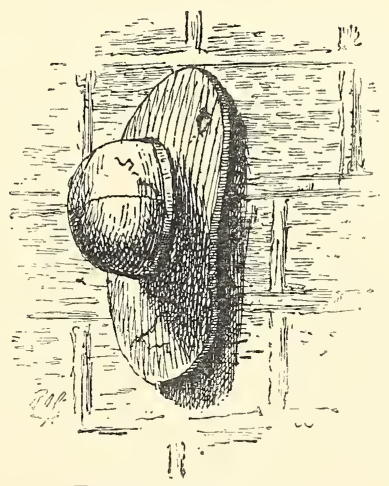

THE BELOVEI HAT. 


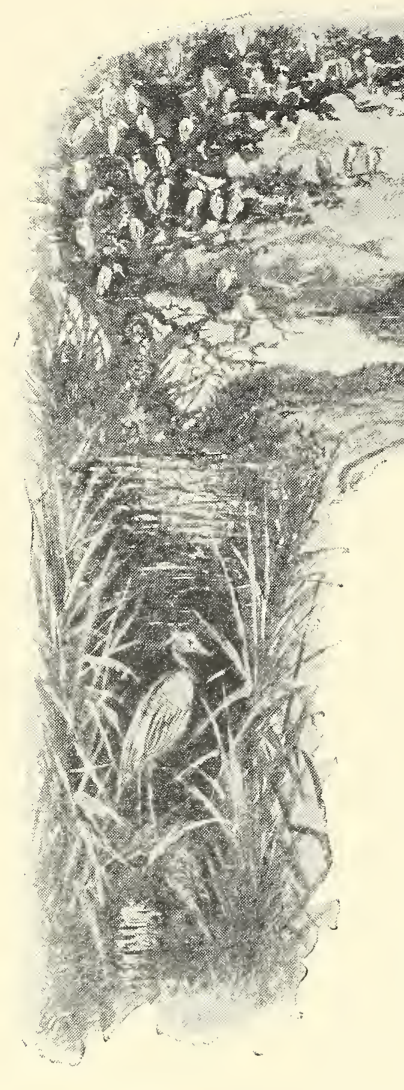

\author{
Chapter X. \\ ADVERSITY.
}

"Hard times come again no more."

IT is a futile prayer, and unwise as futile. Hard times are the birch rod with which Dame Nature disciplines all her children, and the discipline is more needful than most of us realise. Nor is the need of it confined to us. There is an amiable idea, common among people who know nothing of the lives which animals lead, that they are never in want. Poverty and hunger are artificial 
conditions, belonging to man's estate. Creatures of all kinds have plenty of their natural fcod and are never sick or sorry. But this notion is very far from the truth. All animals are in the main happy, I believe and will believe; but I know no recipe for happiness which excludes the flavour of want and pain, and these are everywhere in the world. It is true that we see little sickness or misery among wild animals, but that is because among them extinction follows so swiftly upon failure. The bird, or beast, which cannot keep itself in health and vigour is speedily put out of the way. It is only among us that feebleness and misery are nursed and prolonged.

This seems to me a great and wonderful thing. According to the highest ideal of this age, the goal of all human advancement is expressed in the formula-The greatest happiness of the greatest number. Now it is admitted that in most European countries at any rate the number is nearly made up. They cannot be made to hold many more human beings than they hold already. Yet we feel obliged to be gratified at every step we make towards retaining in life the feeble, the sickly, the blind, the deaf, the idiotic-in short, all those classes of persons to whom any high degree of enjoyment is physically 
impossible. If we got rid of these, each one might be replaced by a strong, healthy, well developed, human being in full possession of all his faculties. This is the teaching of nature and of science. The Spartans recognised it and exposed sickly infants on Mount Taygetus to die. Doubtless many a fond mother yearned for her puny offspring and pleaded that it was not so weak as it looked; but reason triumphed over sentiment, and the unpromising baby was taken away. And what the law of Sparta did for her citizens, the law of nature, as inexorable, does for all living things; till man steps in and declares his unconquerable conviction that it is better that A should be weak and sickly and B should sympathise with him and care for him and sacrifice himself for him, than that A should cease to be and B should be free to care for himself.

It is, I repeat, a great and wonderful thing. Where is the explanation?

\section{"Beyond the veil, beyond the veil."}

Not on this side of it certainly. Among the lower animals there is kindly feeling in many phases, the attachment of the bird to its mate, the affection of the mother for her young; but of compassion and benevolence I find 
not a trace. These were in the fire which Prometheus stole from heaven, and for that theft the vultures are still pecking at his liver. But, howsoever pecked, he still lives and the fire is not put out.

But to return to my first subject, I say that, among animals, death follows upon failure with merciful swiftness. But death is the extreme penalty of the law. Hard times are the scourge, which hangs always on the wall and often comes down heavily. I have seen some curious instances of the shifts to which birds are put when food fails and hunger presses, Near the city of Glasgow, one Sunday in October, I saw a crowd of gulls at a great height in the sky, hawking insects. Some starlings joined them, but were not able for the exertion of soaring at that height and soon came down again. Now think what is implied in this strange spectacle. We are moved at Belisarius begging for an obolus, and shall we not be touched when great gulls turn themselves into swallows and try to catch the mayfly and the daddy longlegs? Civilised gulls too, nurtured in the lap of luxury! For ages their hardy ancestors roamed over the ocean, picking up what they could find, glad to follow the dolphin or the whale and profit by the panic which its presence caused among the 
silvery shoals. But man appeared upon the scene, and wise gulls soon discerned the advantage of keeping close to him. What glorious scrambles there were as the tattooed Briton drew his net to land! What croaking

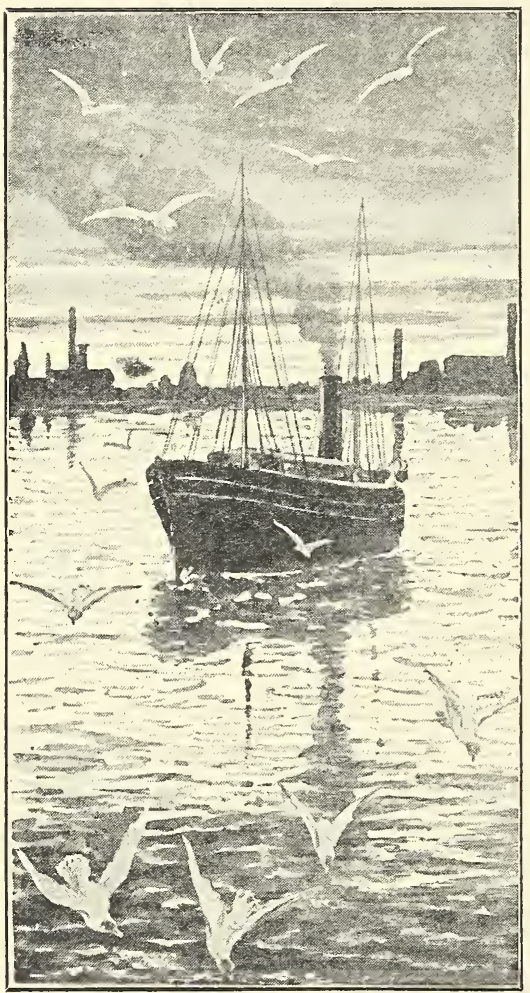

GULLS ON THE CLYDE. and shrieking, what jostling of one another and plunging into the seething mass of frightened fishes crowded ever closer and closer together! So the gulls throve and multiplied all round the coast. Then great steamships began to go up the Clyde, churning the muddy waters and turning up all manner of good things, not to mention the platefuls of scraps which were tossed into the sea after every meal. Doubtless 
salt pork tasted strange at first, and biscuit and potato peel were insipid ; but on a raw Glasgow day a hungry gull is not disposed to be fastidious.

So a flourishing colony soon settled about the Clyde and shared in all the prosperity of the great city and grew fat and lazy. Hard times seemed gone to come again no more. But one year trade is slack, and then wintry weather sets in sooner than usual, before most of the gull families have gone south. And the gull has lived from hand to mouth. There is no store laid up, nothing saved and no credit to be had. Want comes suddenly, and starvation is at its back. And it is the Sabbath day in Glasgow. So the fat, Clyde-fed gull, which was too lazy to dive for a fish, is lean enough and hungry enough to soar up among the clouds for the chance of a few insects.

I will give you another instance. One day on this coast I was sailing down one of our loveliest creeks, when I saw a mangrove tree almost white with herons. Every little branch, or stout twig, every possible foothold, was occupied. And what do you think they were all doing? The tree was in flower, and they were catching the flies which came to the blossoms. What is the 
difference between a great white heron watching at a flower for flies, and an able-bodied Londoner standing at a street corner selling boot-laces? You may say that the Londoner is a lazy scoundrel who adopts that means of making a livelihood simply because he hates honest toil. I find difficulty in believing that a Londoner's livelihood can be made on the profits of laces at a penny per pair; but granting your argument, it applies equally well to the herons. The fact is that indolence is the besetting sin of beast and bird as well as man. Necessity keeps them up, but if the chance is given them of growing lazy and degenerating, they will take it.

"Sic omnia fatis

In pejus ruere, ac retro sublapsa referri:

Non aliter quam qui adverso vix flumine lembum

Remigiis subigit, si bracchia forte remisit,

Atque illum in præceps prono rapit alveus amni."

Not long ago I was encamped near the sea, and every morning I saw a pair of kestrels performing the most wonderful evolutions on the beach. They were not hovering high in air, after the manner of their kind, scanning the ground for some creeping mouse or crouching lark, but flew very low, doubling often and darting about, as if in pursuit of some nimble prey. It took me some 
time to believe that they were after sand crabs. They did not make a large bag, for they were new to the work and did not set about it in the right way. But if they had kept at it long enough, there is no doubt they would have improved by practice. Then, if they had trained their young to the same pursuit, there is no doubt the young would have beaten the parents. In a few generations the structure would have followed the habits, for those parts of the body which are not kept up by constant use soon become unfit for use, while those parts which are employed in any peculiar way soon become adapted to their new task. We may find illustrations of this law everywhere. Tame ducks can scarcely fly a yard, but their legs are stouter than those of wild ducks. Darwin says that the very bones in the leg of the tame duck are proportionately heavier, but the wing bones are lighter. Among ourselves has not baldness followed the use of hats, and are not bad teeth, which decay and torture us before half their term of service is out, the legitimate punishment of our effeminate partiality for tender meat and soft foods? So the claws of the kestrel would have lost their keenness, his beak would have changed its shape, his legs and toes would have grown 
longer, and we should have had a very interesting new species of bird, the crab hawk. But this is not going to happen, for one day those kestrels got dyspepsia from eating too many crabs, and wisely gave them up. This is one notable difference between the lower animals and man. When any article of diet makes them ill, they give it up at once and naturally get well. Man refuses to yield, and raising an army of fierce drugs, fights the rebellious luxury, his stomach being the battle-ground. What a Homeric epic might be woven over the contest which has raged within many a strong man through the best part of a lifetime! It might be called an Iliad too, but of course the derivation would be different. But I am digressing again and must return to my subject.

One more instance will I give you, that of a shrike, which, when insect food was scarce, took to attending at my chotee hazree and eating bits of bread which I threw out for it. In its personal habits this bird was fast hecoming a crow, but other shrikes would not follow it, so it got out of caste and the matter spread no further. When circumstances lead a whole community to take the same course, the character of the species is affected. The sea eagle feeds on sea snakes because they are 
easier to catch than fish. Can it be doubted that the extermination of sea snakes would have a most beneficial effect on the whole nature of the sea eagle, that she would become a far bolder and more enterprising bird? And would not a scarcity of bulbuls and doves be a most wholesome thing for the black eagle, compelling her to give up the disreputable habit of feeding on nestlings and eggs and exert herself to catch some nobler prey?

I have been led into this train of reflections by the season. These are the days of plenty for all the peaceable inhabitants of the land. The frogs are shamelessly jolly, insects of every kind have abandoned themselves to gluttony without thought of the morrow, the sambhur and cheetul on the hills are in danger of dying by surfeit, the very cattle of the village are filling up the long grooves between their ribs and those great hollows in their flanks. And the little birds find food so plentiful that many of them choose this time to bring up their young. A pretty pair of tailor birds have successfully brought up a family of four in a most ingenious little nest made of three leaves in a croton bush in my garden. At what other time of the year could they have kept 
those hungry mouths filled with tender green crickets all the day long? And at what other time could the infants, just learning to use their puny wings, have escaped the eye of the pitiless crow? But a time is coming when food will be scarce and the trees will be comparatively bare. Then the hawks will make their nests, and their young ones will require to be fed with little birds all the day long. The water also will dry up, and there will only be one pool left, and the tiger will know it. Then the sambhur which has indulged too freely in the good things of this life will be the first victim. And the poor cattle! They appeared to have made good progress in the art of living without food, but now they have quite forgotten the bitter lesson. When the time of tribulation returns, it will have to be learned afresh, and their fat sides will feel the stick all too keenly.

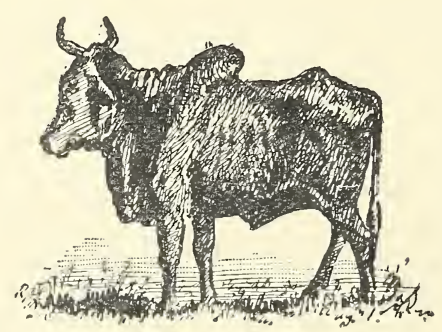



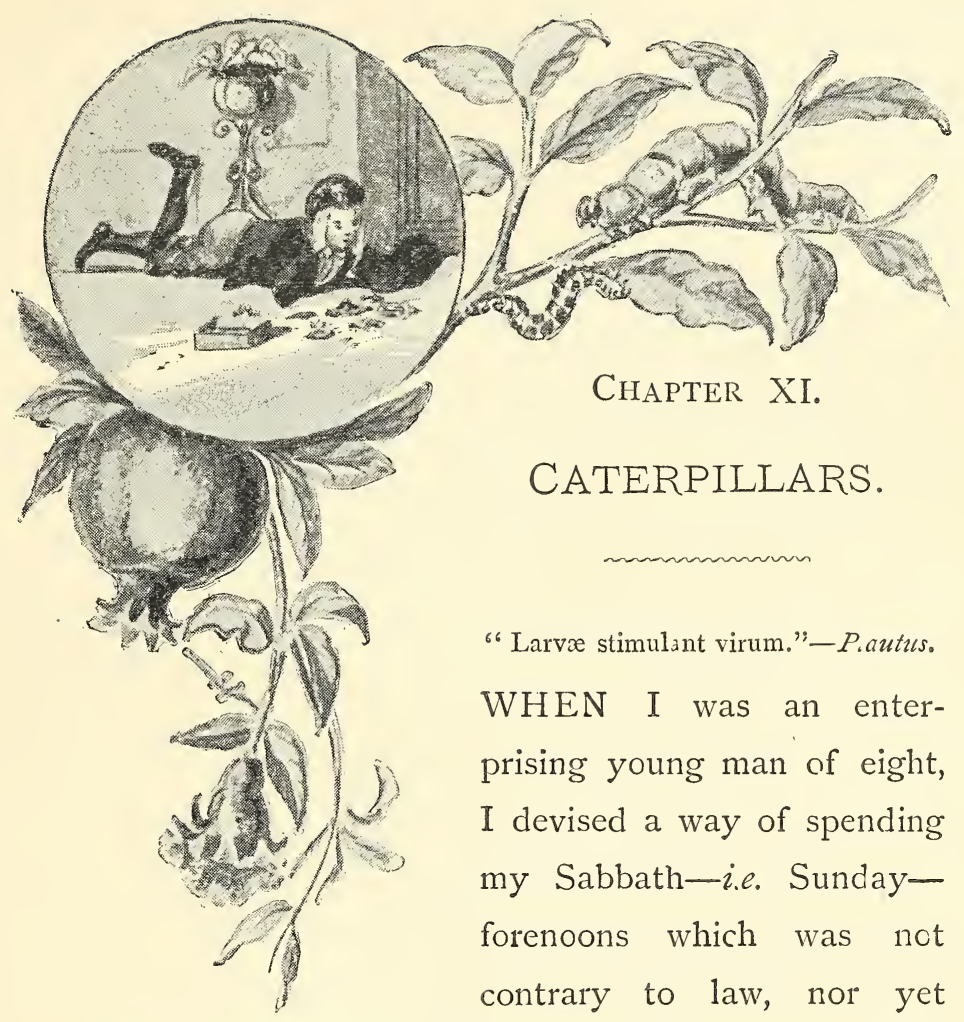

Chapter XI. CATERPILLARS.

"Larvæ stimulant virum."-Paautus. WHEN I was an enterprising young man of eight, I devised a way of spending my Sabbath-i.e. Sundayforenoons which was not contrary to law, nor yet dreary and uninteresting, a very rare combination. This was to bring out my caterpillar boxes, and transferring the inmates to fresh and tender leaves laid out on the floor, to lie down at full length, with my chin on my hands, and watch them feeding. How intensely interesting it was to sce a great Humpy-back, called in bosks a 
Geometer, march along a twig, looping his back up at each giant stride, till he came to a nice leaf, and then to see him try it at different points, till he found a bit to his liking and settled down to eat. He had a pair of jaws which worked sideways, like little pincers, nipping bits out of the leaf, and an upper lip like a sharp knife, following up the jaws with a clean cut. And he ate from the edge in curves, each a little bigger than the last, till a large half moon was cut out of the leaf. But when he came upon a tough rib, he stopped and began at another place. He was a very docile fellow, always ready to eat; quite unlike another pig-headed little beast, which refused to move from the old leaves to the new. I had infinite patience, however, for my heart was in the cause. I put a new leaf edge to edge with the old, and gave him a gentle push behind with my forefinger. This made him begin to move, as I knew it would, but when he came to the new leaf, he got suspicious and wanted to turn back. So I presented my forefinger to his head and checked his purpose. After a time he had advanced on the new leaf as far as his first three pairs of sharp-pointed feet, but the other five pairs, the graspers, were on the old leaf. In this situation he remained, turning his head 
slowly to one side and then to the other, but unable to make up his mind to advance. It was then I found out the fact that for imbecile indecision of character a caterpillar beats all created things. No wonder it becomes a butterfly! With all the skill of a native bullock driver, however, I humoured him, coaxed him, or prodded him behind, as occasion required, until I had him safely on the new leaf, and then, after much vacillation, he began to nibble and I reaped my reward.

There was yet another caterpillar which would not move at all, and I discovered-O glory ! - that it was going to cast its skin. I had to spring to my feet and scamper off to my brother to tell him the news. Then we both lay down, with our chins on our hands, and watched the wonderful process. To this day the peculiar odour of half dry leaves which usually pervades a caterpillar cage has power to conjure up the remembrance of those joys, for the sense of smell has a stronger hold on the memory than even the tones of an old song. My menagerie in those days was never very large. I might have two or three Humpy-backs, half a dozen Woolly Bears of sorts, and, if I had been lucky, one or two butterfly-caterpillars, which were treasures, for humpy-backs and woolly bears pro- 
duced moths. And once I had a Sphinx, a real Oleander Hawk-moth. It was green, with two large blue eyes, and had a thin straight tail, which afterwards grew short and curved. The great comet of 1857 and the finding of that caterpillar were the two memorable events of my childhood, but I remember more about the caterpillar.

More than a score and a half of years have gone by, and I still keep caterpillars, but now I would not stop to take an Oleander Sphinx off the plant. It is absolute rubbish. In one season I have reared fifty or sixty different kinds of caterpillars, some of them rare and beautiful, some new and strange. Yet it is only the truth to say that the interest which they excite in me to-day is cold and dull compared with the wild enthusiasm of those early days. Why is this? Am I blasé, or is it the general doom? Must the interest of life wane for us all as the progress of knowledge curtails the playground of imagination? No doubt it must in a measure, but there is another cause.

I believe that in these days we have too many occupations, too many interests ; we know too many things, and, if you will, have too many advantages and facilities. Our faculty of taking an interest is dissipated and frittered away. There can be no doubt that the summit of earthly 
happiness is reached when the whole soul of a man is focussed on one point. What the point is matters little or nothing. I am speaking of a man's own happiness. To have your soul focussed on one point does not generally contribute to the happiness of your neighbour. It is because the whole powers of a gimlet are concentrated on one point that it bores so well, and a man under the same conditions bores too. This is not a pun, but a glance at the philosophy of human speech. You will gather that I do not altogether recommend the use of any subject as a burning glass to bring all the rays of mind and heart to one point. At the same time I am certain that there are few things in our mental constitution better worth the trouble of keeping alive than that same faculty of taking an interest. But it will not live without food, and that is why I recommend the rearing of caterpillars as a wholesome and palatable form of nourishment. As a pastime it combines the domestic amusement of keeping pets with the outdoor exercise of finding them. And it is good for the entire man. It conduces to bring about and then to maintain the mens sana in corpore sano.

To be a successful caterpillar hunter you must have good wind, service able legs, educated eycs, and more than 
all these; for do not think that caterpillars are to be picked up like shells on the sea-shore. Caterpillar hunting is an art, and if you wish to excel in it you must be well grounded in the principles of caterpillar life. Of these the most fundamental is that a caterpillar is a little creature ordained to be eaten. To avert this fate is the continual aim, not only of all it does, but of all it is. This may not seem quite logical, but I have no time to cavil just now. From books, and more especially from instructive little papers upon protective mimicry and such subjects, you will learn to take it for granted that when a caterpillar is eaten a bird is the eater. Unlearn this. Upon the whole I think birds are the least important of a caterpillar's enemies. At first, when it is so minute that a bird would not be at the trouble to pick it up, it is exposed to the cruelty and rapacity of hordes of ants of many tribes, which scour every tree and shrub, sipping the nectar in the flowers, licking the glands at the bases of the leaves, milking the aphides, and looting and ravaging wherever they go. Besides ants, every tree swarms with spiders, not web spiders, but wolf spiders, which run about in quest of their prey. Then come wasps and ichneumons, and these, from the caterpillar point of view, are of two sorts, those which 
will carry him to their own quarters for the food of their children, and those which will quarter their children on him, or, I should say, in him. Finally, the few that have survived all these dangers have to run the gauntlet of the birds, the restless little tree warblers and sun-birds and bulbuls and tailor birds, which hunt the foliage of the forest and the garden from morning till night.

Some means must be devised whereby at least a few, say one per cent., of the caterpillars which are produced may escape all these perils and arrive at maturity, or else the race will become extinct. By far the most successful expedient that has been tried is loathsomeness; there are some caterpillars which no decent bird would touch. But the taste of a bird is different from that of a fly. What the one loathes the other may love, and no caterpillar can carry two flavours at once; accordingly, I find that those caterpillars which are perfectly secure from birds are the very kind which suffer most from ichneumons. To ward off this pest the swallow-tails have a curious organ in their necks, a sort of forked scent bottle, emitting pungent and poisonous fumes. This they stick out and brandish frantically when they suspect danger. But the little fiend is patient, for it has nothing else to do. It waits till its 
victim is sleeping, and then in one moment the work is done. Thenceforth the caterpillar will carry its worst enemy within it, one which, like the sin of spiritual pride, will grow with its growth and fatten on the wholesomest food it eats. Such a caterpillar is only a semblance, a sham; better that some bird or spider cut short its career. For when the time comes that it should cast its slough and rise to heaven on golden wings, that slough will be all that is left of it, a mere veil to hide the ghastly grub which wriggles and devours within. It is a pitiful fate, but who has pity to spare for a creature that sought safety in vileness? I wish that some ichneumon would infest the garden bug.

Offensive caterpillars generally grow into offensive butterflies, as is fit, and such butterflies, you may infer, are not of the highest order. In colour they are often gaudy, just as sweepers in holiday attire are the gayest members of a Bombay crowd; but they are dull-witted and slow, easy to catch, if worth the catching. Those butterflies which are good for food are usually swift and wary, their senses sharpened by the discipline of danger, and in the caterpillars of these you will find the same qualities in the form of sly caution and tricky ingenuity. Look at the leaf- 
green caterpillars of the swiftest Swallow-tails, of the Fourtailed Pashas, called Charaxes, and of the beautiful and wary Euthalias. How motionless they lic on the upper side of a leaf! Motionless, because spiders attack nothing unless it moves; on the upper side of the leaf, because that is the outward side to birds among the twigs. At long intervals they wander away to feed. Charaxes imna appears to feed only once in the twentyfour hours, and Papilio sarpedon feeds by night.

Then there are offensive weapons and defensiveworks.

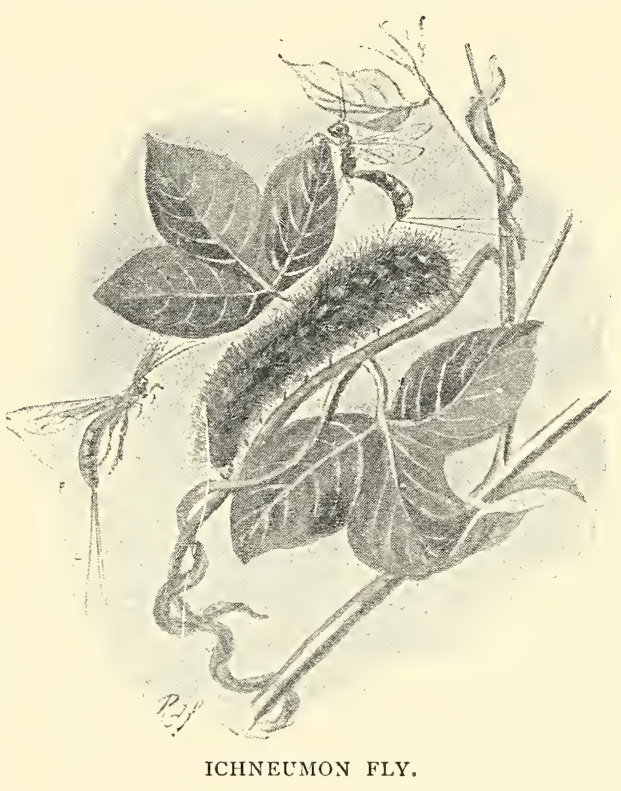
Some are armed with spines, or bristles, or stinging hairs, and these enjoy security to a certain extent; but in this war every move is met by a countermove, and there is no such thing as final safety. I once saw a large, hairy 
caterpillar resting drowsily on a leaf, with two villainous, red-eyed flies standing by watching it. I felt sure there was mischief afoot and determined to see it out. In a short time one of the flies approached the caterpillar cautiously, till she almost pressed against the long tufts of hair which grew out of its side. These held her at bay and she could get no nearer. But she was provided against this difficulty. Quietly she took out of her pocket an ovipositor, which opened like a telescope till it was nearly half an inch in length. Passing this carefully between the tufts of hair, she stuck an egg on the soft under-parts of the caterpillar without even awakening it. Then she drew back with a tread as stealthy as that of a cat, and moving a few paces further, stuck another. This she repeated several times before my eyes, and I never thought of interfering: I was too much interested. Besides, who was I that I should interfere?

But I find more interest in those caterpillars which, coming into the world without armour of any kind, and being savoury meat, elude death by cunning disguises, or skilful works of defence. Some make burrows in the hard trunks of trees, but this requires special and very powerful jaws, which do not consist well with the plan 
on which butterflies and moths are constructed. It better becomes the grubs of beetles. Others build them houses of leaves, joining their edges with silk, or curling them spirally, and some make the most wonderful coats of strong thorns. A small moth caterpillar, which feeds on the water lily, cuts off a bit of a leaf, with which it forms a boat and sails away on the surface of the water. Another, which may be ranked among our domestic animals, feeds on our clothes and wraps itself in a woolly mantle made of the nap. Yet another makes itself a portable boat-shaped house of silk, coated with fine sand, in which it walks the walls of our houses, feeding, I believe, on invisible moss or mould.

But of all the defensive works I have seen, the most advanced is that of a delicately beautiful butterfly called Limenitis procris. When the caterpillar comes out of the egg, it betakes itself at once to the very point of a tender leaf and eats down steadily on both sides of the mid-rib, which stands out bare and dry. As the little thing advances it cuts up much more of the leaf than it eats, and these crumbs, with other refuse, are gradually accumulated and loosely bound together with silk till they form a breastwork across the whole breadth of the leaf. 
Behind this rampart of refuse, of which its brown and ragged form seems to be a portion, the little architect lives, pushing the work back from day to day as it eats on.

What shall I say of those caterpillars which have some powerful tribe of ants for their patrons and protectors? I will pass by them to-day, for I feel assured that the history of that alliance belongs rather to the annals of the ant. But there is one device yet which I cannot pass over, resorted to by the caterpillar of one of our most brilliant Blues. I have always ranked the Blues among the aristocracy of the butterfly world, and even among them the family of Virachola is one of the noblest. Brilliant in colour, swift in flight, distinguished in bearing, it is the peer of even the Four-tailed Pashas. The birthplace of this proud creature is the fruit of the pomegranate. In the very heart of the fruit it passes its early life, feeding on the forming seeds. For ventilation and sanitation it makes a hole in the tough rind, and every day sweeps out its apartments with a shovel which grows on its tail. But in a short time the fruit begins to grow black and wither, as its heart is eaten away. Soon it would fall to the ground and rot, and its inmates would perish miserably. But before this can happen the cater- 
pillar comes out by night and ties the fruit to its stalk with silk so securely that it will defy the winds for a year to come.

I once took down a pomegranate which was occupied by several of these caterpillars, and put it on an egg-cup. During the night they came out and fastened it so firmly, that when I lifted it in the morning, the egg-cup was lifted with it. This is positively the most wonderful thing I know, and it grows more wonderful under the pantoscope of modern science. For till recently we could always explain such things by instinct, which was a terse and reverent expression of ignorance. But now nous avons changé tout cela, and instinct belongs to the language of mythology. We cannot substitute intelligence: that would be worse than instinct. Therefore, it is certain that this habit of tying pomegranates to their stalks was originally an objectless insanity, which, chancing to be advantageous to the lunatic himself, was perpetuated by the great law of the survival of the fittest.

But I have said enough about the dangers which beset a caterpillar's life and the devices by which they are met. We must next consider the bearings which these things have on the pursuits of the caterpillar hunter. 


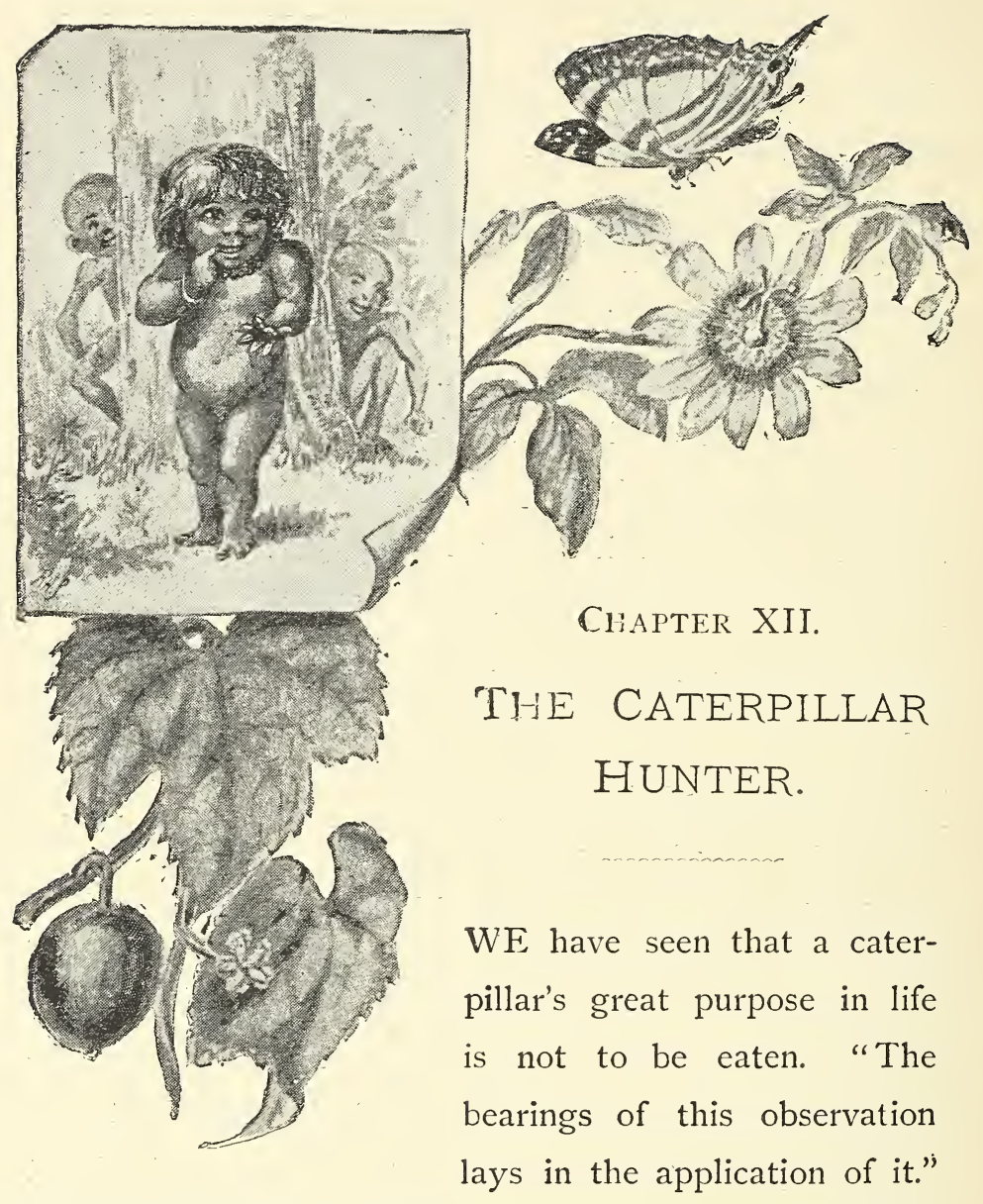

For the simplest way not to be eaten is not to be found; but I want to find it, and against all its other enemies I am an amateur competing with professionals. Happily 
for me, it has another purpose in life which, now that I think of it, is even more absorbing than the first. It would like not to be eaten, but it must eat. Now a halfeaten leaf easily catches the eye, and the thought that this effect must have had a cause easily suggests itself to the mind. But there are other things besides caterpillars which eat leaves: goats do, crickets do, beetles and ladybirds do. Fortunately each of these eats in its own way, and practice soon teaches one to diagnose " eating."

From the experience gained in my early days I know that a caterpillar eats from the edge in curves, but a beetle eats holes out of the middle of a leaf, and a leafcutting bee cuts out neat semicircular pieces all of the same size. A cricket, or grasshopper, may eat like a caterpillar, but when it has finished a meal it hops away to another branch, while a caterpillar, being an indifferent walker, will generally stay at one place, finishing leaf after leaf.

So, when you see "eating," your first question must be, Who did it? If the answer should be, A caterpillar, you put your second question, When? Domestic experience is useful here. Your butler says a plate was 
broken in the time of his predecessor, but you mark the fresh surface of the broken edge and convict him of deceit. A leaf may be judged in the same way. So, having come to the conclusion that the leaf has been eaten by a caterpillar, and that lately, you put your final question, Where is he? Under a leaf, or motionless on the upper side of one, or in a cunning chamber, or lurking about the stem. Perhaps before your very eyes as you search, telling a lie. It may be standing on end, as stiff as a stick, and saying, "I am only a broken and withered leaf stalk," or it may be lying close along a twig, like a swelling or deformity of the plant. Or it may have dropped to the ground the moment you touched the branch on which it was feeding. From the indications afforded by its appetite you may make a near guess as to its size, which will help your search; and if you are a botanist, you may even conjecture to what genus it belongs, for each genus has a traditional attachment to some particular order of plants. The end of it all will generally be that you will not find the caterpillar.

It often happens, however, that one does find caterpillars. Where honest search fails a curious accident 
comes in, or your own good luck, or the bad luck of the caterpillar, puts in your way what you least expected. My faith in luck has never been robust, but I know that, if you only give it a fair chance by covering plenty of ground and keeping your eyes open, you will make good many discoveries.

Some of the best things I have got were found by noticing butterflies hovering suspiciously about one place and watching them patiently until I saw them lay their eggs. Once a rare swallow-tail passed me, and I started in pursuit, but soon guessing her purpose, stayed my hand and watched. After circumnavigating one tree many times she settled on a tender shoot, where she remained for some minutes and then flew away, leaving ten golden eggs, one upon another, like a jointed stick.

This was the only butterfly which I ever knew to deposit its eggs in such a fashion; they generally lay them singly in different places. Moths, which are altogether more stupid, usually lay them in a lump. Some do not even take the trouble to look for a tree on which their offspring will feed, but leave that to luck.

In some parts of India I have heard of great things being accomplished by employing native agency, but 
here there are no children of nature, no hill tribes or aboriginal races, and the ordinary Hindoo peasant has his eyes and ears closed against everything which has not some direct bearing on his necessities or comforts. He knows many of the trees or plants. One is an antidote for snake-bites, another cures hydrophobia, a third is essential in ceremonies for casting out the devil or arpeasing the goddess of small-pox, a fourth allays pain in the stomach, a fifth corrects heat in the blood, a sixth. expels wind from the joints, a seventh reduces bile when it has mounted into the head, an eighth is a good plaster for boils, a ninth should be rubbed on the soles of the feet to strengthen weak eyes. In fact, the whole jungle is to him a vast box of Holloway's pills and ointment, offering a panacea for every ill to which flesh is heir and many to which it is not.

He also knows many flowers which serve as offerings to his gods, and his wife well knows as many which look very nice in her hair, but neither he nor his wife seems to see the butterflies or hear the birds. And their children do not string birds' eggs, nor run after butterflies with their caps.

Nevertheless we once determined, a friend and I, to see what could be done with them, and we met with some 
success. In our rambles we were followed by three boys who carried spare nets, pill boxes, and killing bottles. These were our raw material, and it was very raw. They did not wash their faces, or brush their hair, and their garment was scanty and unclean. When rain came on they would crowd under our umbrellas, and at such times how forcibly they recalled an old traveller's description of the skunk, which "hath a ventositie so strong and so evil of scent that it doth penetrate the wood, the stones and all that it encountreth withal, and it is such that some Indians have died with the stench."

If asked the name

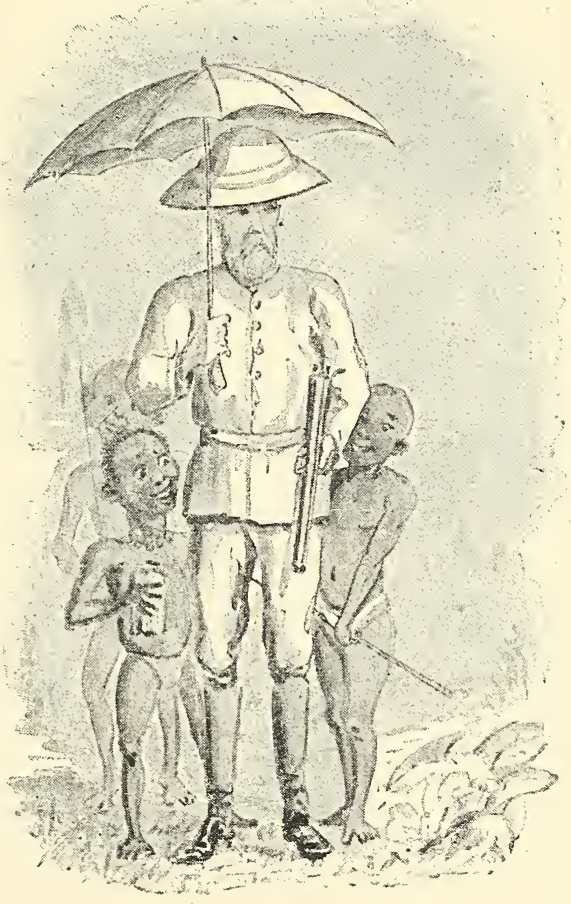
"PIGS." 
of a tree, they did not know, for not knowing would avert further trouble, and they were not yet civilized enough to invent names to please us. But the seed of intelligence was there, not dead, only dormant. We manured it with pice, and it germinated and began to grow. They took to looking about them as they followed us, and would draw attention to a butterfly or a bird. Then they began to find caterpillars.

We addressed them endearingly as "Pigs." In case this meets the eye of any Member of Parliament, I should like to explain that the word was not used in an offensive sense, and had nothing to do with the opprobrious term soor, or sowar, which, as Mr. Schwann, M.P., who has travelled in India, must know, means swine, and is commonly applied by Anglo-Indians to Native Cavalry. We made use of the English word, accompanying it with a kindly smile, and we can safely affirm that the little boys appeared to be proud of the title and tried to live up to it.

Presently it began to be known in the bazaar that the Pigs had discovered a new and lucrative industry, and other boys began to appear about the gate, coughing and spitting to attract attention. In their hands they clutched the remains of a battered butterfly, or a snail, 
or an earthworm. We felt inclined to box the dirty ears which stood out like jug handles from their shaven heads, but we smiled and gave them pice pour encourager les autres.

Soon the whole juvenile population was abroad, hunting for any small thing that had life in it. Among them were a few Pigs of marked talent, who soon found out what we valued and explored the jungle in all directions for new and rare kinds of caterpillars, but the majority were afraid to go into the jungle at all lest panthers might eat them, so they wandered about the hedges round their fathers' fields. Their intellects, too, never got beyond the argument that what you paid them for yesterday was the thing to look for to-day. It came to this, that we had to maintain a drove of several score, who spent their time in getting what we did not want, for the sake of the two or three who might get what we did want. So we began to pay at lower rates and to refuse altogether the commonest kinds. This led to the discovery that the brain of the Pig is not deficient, but only misapplied. Indeed, they displayed a subtlety which was quite shocking in creatures so young. When an old hand brought some common caterpillar for the twentieth time and found that it was refused, 
he retired for half an hour, then sent his younger brother with it. If he, too, was refused, they brought out their little sister, clothed only in her own charms and a necklace of beads, and closing her tiny fingers on the leaf, directed her toddling steps to our door and put themselves out of the way. It is needless to say that her chubby little face and black eyes did their work, and she went away with a bright two-anna piece in her puny fist, which the young rogues outside the gate promptly extracted.

Another standard trick was to divide their spoils. Supposing an astute little Pig discovered five specimens of a caterpillar, for which he calculated he might get an anna, he sought out four other Pigs like himself, and they took one each. The first appeared at the front door, the second at the back, and the others followed at short intervals. We could not give less than one pice to each; we probably gave two; so they realized more than two annas for the lot.

Even those superior Pigs who found rare caterpillars learned not to spoil the market by bringing too much at once. If they found several of one kind, they would bring one first and the rest by degrees. I often wondered what they did with the money they got. Did they indulge in 
sticks of juicy sugar-cane, or bundles of "old woman's hair," or did they lay out their pice in alley taws and paper kites? Or is it possible they spent their earnings in the furtive enjoyment of country tobacco ?

They were mostly the children of very poor parents, and anything they were known to possess was pretty sure to be escheated to the family treasury, but I daresay they contrived to deceive their fathers and mothers as cleverly as they duped us. Poor little Pigs! The race is becoming extinct now, for I have got almost everything they are likely to find, and I cannot maintain a population for the chance of a lucky discovery now and then. And it is as well. They have returned to the wholesome routine of their lowly lives, and my conscience is more at ease since I ceased to be the cause of the perishing of hundreds of harmless creatures.

They have not forgotten me, however, and I am often greeted by a half impudent salaam from a nude urchin in his native gutter, or a sturdy brat mending his father's nets, or a nice-looking boy, in a suit of jail cloth, returning from the carpenter's shop, where he is now serving his apprenticeship. He catches my eye and smiles comically, as much as to say, "I was a Pig once." 
The joy of finding caterpillars is prolonged into the pleasure of keeping them, and again the same first principles must be borne in mind. Your main concern must be to see that they are not eaten and have always plenty to eat. If you let the leaves get dry and hard before you change them, the caterpillar may not die, but it will certainly become a stunted butterfly. A caterpillar, like salad, should be grown fast and brought to maturity as quickly as possible. And when it prepares to pass into the chrysalis state, the ease and safety with which it gets over the crisis will depend very much upon how fat it is. An unhappy caterpillar, on the point of death by starvation, will sometimes save its life by becoming a chrysalis, but this is a cruel alternative, an untimely end. Eating is the appointed pleasure of its lower life, and it is not ripe for a higher state until its skin can no longer hold it. Therefore be kind and give it plenty of fresh and tender food. Some leaves will keep for a day easily, others must be kept in water; but remember that, if your caterpillar can get at the water, he will walk into it and stay there till he drowns. This proceeds from ignorance. Those kinds which feed on growing rice and are familiar with water never do such a thing. 
As to accommodation they are not hard to please. Any box will do, but some kinds must have light. Infants fresh from the egg are often very difficult to rear. I always keep them in glass tubes, or small bottles, tightly corked. This keeps the leaves fresh for several days, and the silly things cannot wander and lose themselves. Ventilation, fresh air and sanitation are wants of modern civilization, to which caterpillars have not yet adapted themselves, and I never found them to suffer from this corking up unless the bottle got so dirty and damp that mould set in. But why should I go into details and cheat you of the pleasure of finding out? I always feel thankful when I call to mind that in my early days I had no books.

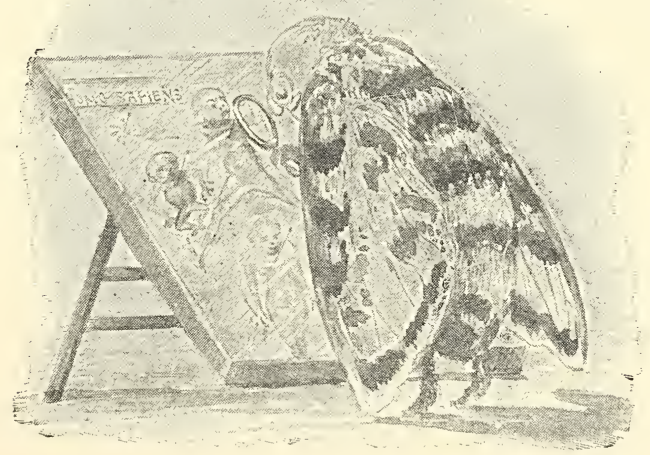




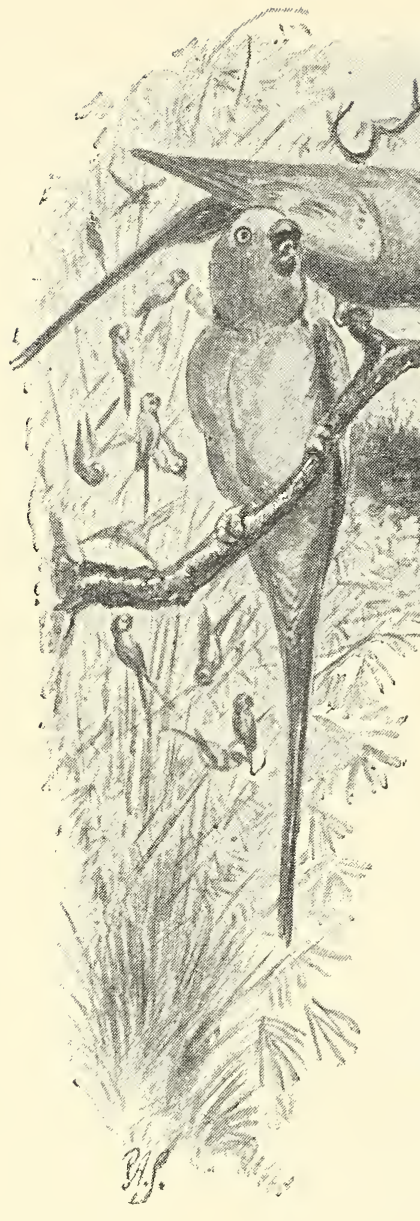

FOR the last two months the rain has been simply ridiculous. Last week the weather did seem to vacillate for a few days, but I rashly planned an excursion for Gunputtee day, and the deluge returned with renewed resolution. We have had nearly eleven feet already, but 
the total up to date goes on rising at the rate of several inches a day. The people say that this rain is particularly good for the crops, and so I find it. The crops of mould and mildew have grown rank beyond all precedent. If I neglect my library for a few days a reindeer might browse upon the lichens that whiten my precious books. The roots of these vegetables, penetrating the binding, disintegrate the glue underneath, so the books gradually acquire a $\operatorname{limp}$ and feeble-minded aspect, and presently the covers are ready to come away from the bodies; and the rain has undoubtedly some effect of the same kind on ourselves. How is it possible to keep up any firmness of mind or body in such weather? It is too dark to do anything inside the house and too wet to do anything out of it.

Peter, the Parrot, enters deeply into the general dulness. If it were fair he would be sitting in some shady bush in the garden, nipping the leaves off one by one and strewing the ground with them, but now he is confined to his cage with nothing to do. He looks at me so longingly as I pass, that my heart, already flabby from the effects of the weather, is quite softened, and I have to open the door and let him get on my shoulder. This consoles him, and 
he grows cheerful and soon sets out on a tour of inspection. $\mathrm{He}$ is wonderfully interested in my watch-chain, and more so in the buttons of my coat. He has not succeeded in getting them off yet, but I can see that he does not mean to be beaten. Nine-tenths of the pleasure of a parrot's life lies in the use and misuse of its beak, which is a wonderful instrument, quite unlike the beak of any other bird. The upper part is not firmly dovetailed into the skull, but joined by a kind of hinge, on which it moves up and down a little, so that the points of the upper and lower parts play freely against each other and can do very neat work in the way of shelling peas, or husking grains of rice. The muscular and sensitive tongue works like a finger, holding the grain in its place, or turning it round, as the operation goes on. With such artistic apparatus feeding becomes an art, and a parrot's meals take up half the day. He will not bolt his food like a gross crow, to whom fresh meat and putrid fish, dead rats and hens' eggs all come alike, but tastes every morsel, and eats one part and throws away ten.

Peter's special luxury is bread and butter, and he eats the butter and throws away the bread. $\mathrm{He}$ is fond of rice too, and puddings and dry grain and nuts and buttons and 
the ends of pencils. I think he is the most lovable pet I have ever had. He was brought to me as an infant, neglected, dirty and ragged. Torn from his parents at that tender age, his affectionate nature clung to me, and he seemed as if he could not live without me. He would follow me from room to room and sit under my chair, and if I called to him from any distance, he would answer me. He is older now and more independent, but he still feels lonely without human society. He keeps up an affectation of a very bad temper, rushing at my fingers with barks and threats, but he is never rude towards my face. He treats my lips with touching tenderness, and I often allow him to amuse himself trying to draw my teeth.

Parrots are almost always spoken of in the feminine gender, but half of them are masculine. Peter has not determined his sex yet, so I have given him the benefit of the doubt.

There can be no question that parrots have more intellect than any other kind of bird, and it is this that makes them such favourite pets and brings upon them so many sorrows. Every cold season you will see in the Crawford Market in Bombay large basket cages, made for carrying chickens to the bazaar, but now filled with 
unfledged parrots, crowded as close as bottles on a shelf, all bobbing their foolish heads incessantly and joining their hundred voices in meaningless infant cries. Men will buy them for two or three annas each and carry them off to all quarters of the native town, intending, I doubt not, to treat them kindly; but "the tender mercies of the wicked are cruel," and confinement in a solitary cell, the discipline with which we reform hardened criminals, is misery enough to a bird with an active mind, without the superadded horrors of poor Poll's life in a tin cage, hung from a nail in the wall of a dark shop in Abdool Rahman Street. Her floor is tin and her perch a thin iron wire, so her poor feet are chilled all night, and if her prison chance to hang where the sun can reach it, then for a change they are grilled all day. Why does the Society for the Prevention of Cruelty to Animals never look into the woes of parrots?

On this side of India we have four kinds of parrots, or, more properly, parrakeets, for they have all long tails. The commonest is the Rose-ringed Parrakeet, neat but not gaudy in its bright green suit, with a necklace of pink and black ribbon and a beak of red coral. I suppose that three-fourths of the inmates of the jails of our Bombay 
fanciers belong to this race. In its native state it lives a joyous and social life, tasting every good thing in garden and field while the day lasts, and at sunset resorting to the club, where hundreds of its kind meet to pass the night in company. Then there is screaming and shrieking indescribable. Under adversity it nurses malice and becomes implacable. You may say. "Pretty Polly" in your gentlest tone and chirrup winningly, but she will just stiffen a little, and her eyes will grow all white, and you had better not put your finger too near the bars of her cage. Yet Polly can love as well as hate if you only give her as much reason.

She is an apt pupil too, and can learn to speak so plainly that, if somebody tells you what she is saying, you can make it out quite well. Thomas Atkins often whiles away the monotony of barrack life in the tuition of parrots, and when you hear his pupils talk you almost fancy they are quoting from the works of Rudyard Kipling. A friend of mine, who wanted very much to take an educated parrot home with him, went to the Soldiers' Industrial Exhibition at Poona, where he saw a handsome bird for sale, with a sheet of foolscap hanging from its cage, in which were detailed all the pretty things it could say. Standing near 
by was the owner and educator, pretending to be on duty. My friend knew something by experience of the danger of introducing Barrack parrots into polite society, so he asked the soldier, "Does this parrot say any bad words?" With a faultless salute Mr. Atkins replied, "I can't say now, sir;

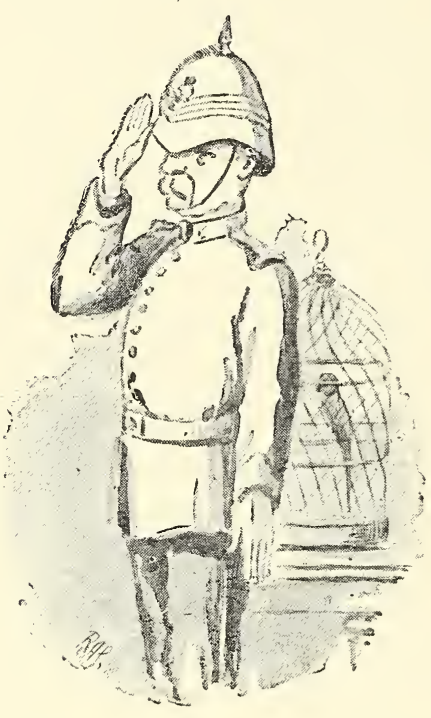
she has been three days in this place." My friend decided not to bliy the pupil of such a master.

But teach her what tongues you will, Polly never forgets her own, and this is my one objection to her as a pet. However happy you make her captivity, imagination will carry her at times to the green fields and the blue sky, and she fancies herself somewhere near the sun, heading a long file of exultant companions in swift career through the whistling air. Then she opens her mouth and rings out a wild salute to all parrots in the far world below her. Like arrows through your cloven head those screams chase each other. If you 
try to stop her, she gets frantic and literally raves in screams. There is only one thing you can do that will avail at all. Dash a whole glass of water over her and she will stop instantly. But this is bad for the drawing-room carpet.

The Alexandrine Parrakeet is not common till you get further north than Bombay, but many find their way to the market there. It is a much larger and coarser looking bird than the last, but very like it in colour. I believe it is supposed to talk better. It sis named after Alexander the Great, who took one back with him after his visit :o this country.

The swift-flying Roseheaded Parrakeet does not

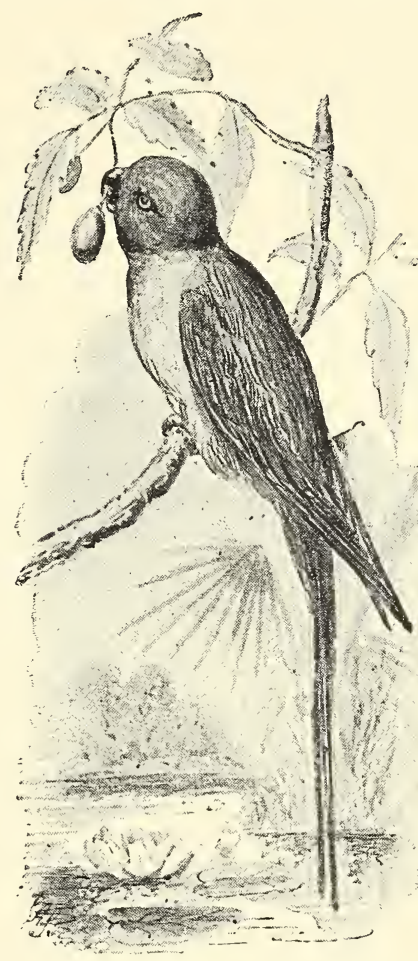

ROSE-HEADED PARRAKEET. come much into our gardens, but all down the West Coast it is almost commoner than the other two. It ravages the 
rice fields, and little boys are busy all day flinging stones at it. I have longed to tell them that they sinned against their own natures when they tried to dash to pieces with rude stones a creature so lovely, and that they should rather rejoice to see it eat and be happy. But the son of the rice farmer is a utilitarian, and in this disjointed world of ours there is a hereditary feud between the useful and the beautiful. It should not be so: there must be some way of reconciliation, but no one has worked it out. Hence our shrieking railways and smoke-belching factories, and the bottomless pits where grimy diggers find the food for their greedy furnaces. And when the beautiful would fly from such companionship and leave us altogether, we shut it up in a fenced place and call it a park, or a people's garden. On a smaller scale, in the alleys and lanes of the bazaar, a poor man here and there cages beauty in the form of the little Rose-headed Parrakeet. He has not heard that saying of Goethe: "Men are so inclined to content themselves with what is commonest; the spirit and the senses so easily grow dead to the impressions of the beautiful and perfect, that everyone should study by all methods to nourish in his mind the faculty of feeling these things. For this reason one ought, every day at least, to hear a little song, 
read a good poem, see a fine picture, and, if it were possible, speak a few reasonable words." But he dimly feels the truth which these wise words set forth. The narrow circle of the poor parrot's cage does not allow it to turn without breaking the long blue feathers of its beautiful tail, and the roseate tints of its head lose their lustre when long shut out from the influence of the sun; but at the worst it is a lovely bird. The head of the female is of a bluish plum colour, and the young ones in the market are green all over, but you may always distinguish them by their yellow beaks. The voice of this parrot is musical and bearable even when it screams.

The fourth kind is the Blue-winged Parrakeet, and to this Peter belongs. It is a forest bird and keeps away from man and his habitations. It has no rosy nead, or pink collar, but the dark greens of its upper parts, and the fine grey and dove colour of its head and breast make it a handsome bird. The quill feathers are deep blue, and the beak of the male is red, while that of the female is black. Peter has not come of age yet. His dress, though tasteful, is plain, and his beak reminds one of that metaphor in "Hudibras,"

"Now, like a lobster boiled, the morn

From black to red began to turn." 
This kind does not screech. Its voice is low pitched and richly harsh.

We have yet one other bird of the tribe, the Lorikeet,

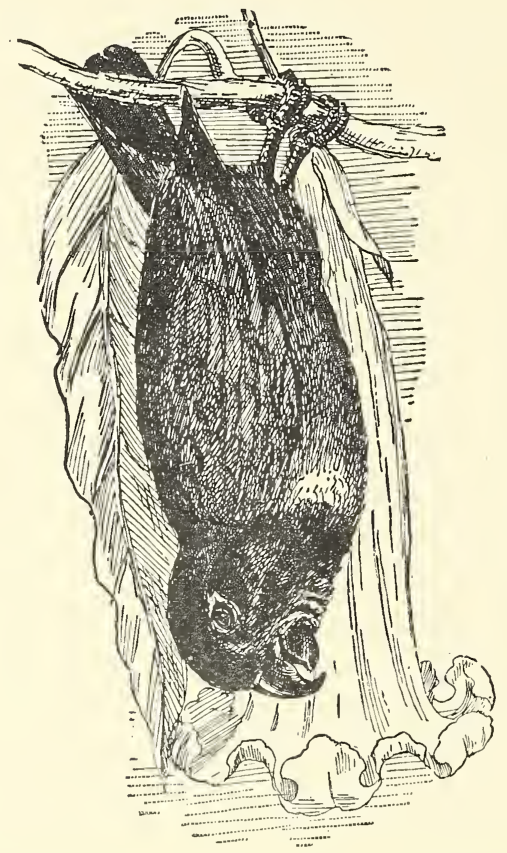

LOVE BIRD SLEEPING HEAD DOWNWARDS.

or Love Bird, a quaint little thing, as big as a sparrow and as green as grass, with a blaze of red on its back. Why it is called a Love Bird I cannot tell It is not 
fuller of love than other birds, but it is a charming little pet and has an original mind. It sleeps upside down, hanging by its feet. Living up among high trees, not larger than one of the leaves and quite as green, it does not thrust itself on your notice; but if you learn its call and bring your ear to the aid of your eye, you will discover that it is as common as the Bulbul. You need not tell this to the old Bird-man, who hawks them about with Canaries and Java sparrows. He knows that they come from Mozambique, and that is why they are worth five rupees a pair.

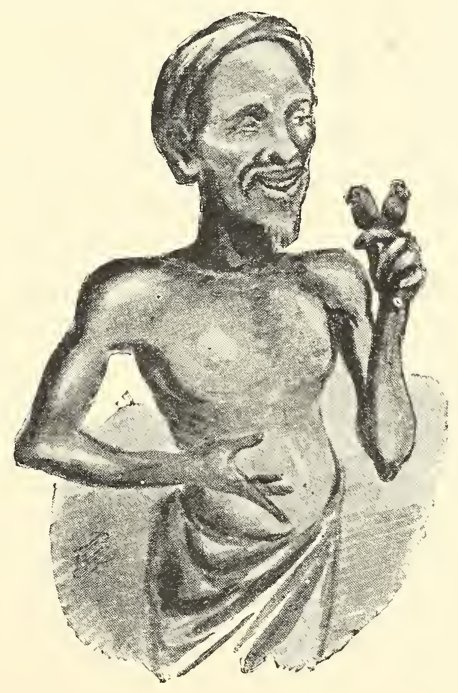




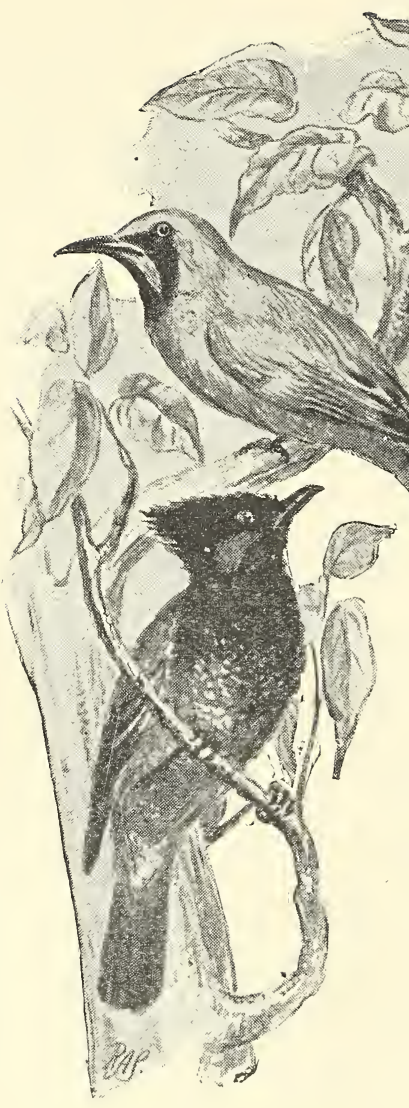

AS pets Bulbuls come next to parrots, but not for their intelligence. I believe their brain is small. A Bulbul has a lively and inquiring mind, and can be taught amusing tricks, but it shows all the signs of little-headedness. The secret of its popularity is its vivacious temper and cheery disposition. Bulbuls do more to keep the world lively than any other bird I know of. They do not sing outside 
the pages of Lalla Rookh, but they have sweet voices and light hearts, and they seem to bubble over with a happiness which is infectious. They are also easy pets to keep. If a bird's food in its wild state consists of insects only, then it is generally difficult to find an artificial substitute suited to its digestion; but when a bird eats both insects and fruit, as the Bulbul does, then almost anything will agree with it. You may give it meat, raw or cooked, bread crumbs, pudding, potatoes, fruit, or anything that is going, and the greater the variety the better it will thrive. It is good, however, to have some staple diet, some staff of life, and let the other things be luxuries. For Bulbuls, Mynas and all miscellaneous feeding birds, I believe there is no better regular food than parched gram made into fine flour and moistened with water. I learned this from my friend the old birdman in Bombay, but he sometimes mixed the flour with ghee instead of water, to oil the bird's throat and make it sing sweetly!

Last year a young Bulbul was brought to me in a very dilapidated state. Some native boy had found it, and, after the manner of native boys, had carried it about swinging by a string tied to one leg. At least, I suppose 
this was how it had been treated, for one leg was dislocated. I took the poor bird in hand, not because I hoped to save its life, but because I am weak about putting birds to death in cold blood even to end their misery. I did save its life, however, and after a long while even the broken leg restored itself in some way and became as sound as the other. In course of time a new suit of clothes arrived, of Dame Nature's best make, and my dingy little cripple became a very stylish-looking bird, with a peaked, black crest on the top of his head, a little patch of crimson over each ear, and another display of red on what ornithologists euphemistically call the "under tail coverts." The only thing that marred his beauty was a scar across the bridge of his nose, which he made and kept fresh by frantic efforts to get out between the bars of his cage whenever he was frightened.

As I have said, the Bulbul has a small brain, and this bird occupied a strong cage for a year without finding out that dabbing his head against the wires would not get him out. Neither did he attain to the knowledge that a red handkerchief, a hat and a hundred other common things do not eat Bulbuls. So he was seized with panic many times a day, and the place where the wires caught 
him, just above the beak, was always bare and often raw. Yet with his equals he was a bold and pugnacious bird. He accounted me his equal and would maintain an obstinate fight with my hand until I knocked him out of breath. Nothing kindled his ire more than Baby's fingers trying to grasp him through the bars of his cage. $\mathrm{He}$ panted to exterminate them. Poor Billy enjoyed the two principal conditions of longevity - a good digestion and a small mind; but he got fits and died early.

Billy was a Red-Whiskered Bulbul, the species which an old naturalist in a happy moment called Otocampsa jocosa, under which name you will find it in Jerdon. The common species of our gardens is the Madras Bulbul, a bird which is only a shade less sprightly than the Red-Whiskered, and to my mind handsomer. Its whiskers are not red, but its head, crest and face are glossy black, and its mantle is a fine smoky brown, the pale-edged feathers making a pattern like the scales of a fish, and the whole effect accords with the maxim of Polonius-

"Thy dress the richest that thy purse can buy, But not expressed in fancy."

The only touch of fancy about it is the crimson seat of 
its trousers, and this is the badge of all Bulbuls; they must have a patch of bright colour on that place. The Sind Bulbul wears it yellow. Another badge is the upturned crest, which expresses the gleeful heart. If you watch a canary, or any other merry-souled bird, you will see that it smiles by erecting the feathers on the top of its head. Now, by a natural law, the feathers which are constantly being erected are developed and grow upwards, and what was a passing expression in the ancestor becomes a permanent feature in the descendants. So every man who cultivates a grumbling disposition is labouring to bequeath a sour face to his children. On the other hand, the merry twinkling eye with which some men are born is nothing else than the crystallised result of a thousand humorous thoughts in past generations. This is my philosophy of evolution.

These crested Bulbuls are the true Bulbuls, but the family ramifies into a great variety of birds more or less bulbuline in their dress and customs. There is the Whitebrowed Bulbul, a dingy-coloured bird which comes about Bombay gardens and lets its feelings off every now and then in a spasmodic rattle of sweetish notes, in which, however, I recognise the family voice. It has 
attained to cheerfulness, but not to hilarity, and its head is only beginning to get crested.

Then there is the cheerily fussy Yellow Bulbul, not a garden but a forest bird. I estimate that it makes twothirds of all the noise that is made in these jungles. There is the rarer Black Bulbul also, and the Rubythroated Bulbul, and many others. I think good Dr. Jerdon goes too far in including Iora among the Bulbuls. Iora is a bright little bird, but not a Bulbul.

There is another bird which Jerdon calls the Green Bulbul, but he admits that it is not a very near relation. By its form, its nest and its eggs the Green Bulbul is an Oriole, but there is a difference depending on its colour. Or perhaps its colour depends on the difference. Which is cause and which effect, is a question on which we have no information. Bird history does not go back far enough. The thing which is evident is that, in the world to-day, the Green Bulbul expresses quite a different idea from the Golden Oriole. The latter is designed to be seen; the former is designed to be unseen. Who does not know the Golden Oriole, or Mango Bird? It cannot escape notice and does not try. Its loud mellow voice salutes the ear, as its brilliant hues catch the eye. But 
how few know that there is such a bird as the Green Bulbul! Yet it is everywhere, hopping about among the green leaves, unobserved, but observing everything and mocking all the birds in turn. First there is a King Crow calling cheerily in the tree just over your head; but you look for it in vain; there is no King Crow in sight. Suddenly it stops, and the fierce scream of the Sparrow Hawk takes its place; but where is the Sparrow Hawk? In a few minutes a Sunbird is twittering just where the Sparrow Hawk must have been; then two Sunbirds are quarrelling. This is too absurd. You fling a stone into the branches and a small green bird gets out at the back of the tree and flits across to the next, where the King Crow immediately begins to call. And all the time the blackguard is sitting quietly amongst the leaves, his head bent down and his twinkling black eye enjoying the effect of his mockeries.

How is it that a bird so talented and dressed so superbly is never made captive by man and put into his dungeons to make him sport? When the Bombay birdman comes round with his Canaries and Parrots and stupid blue Java Sparrows and emaciated white mice, twirling away their weary lives in little wire wheels, he has 
very often some odd bird that has fallen into his hands by accident. In his cages I have found a Cuckoo, rescued from vengeful crows, a Mango Bird, a Button Quail, even a Water Hen maimed with a shot meant for duck or snipe, but never a Green Bulbul. I had long set my heart on having one for a pet, and at last found a nest with two young ones almost ready to fly. Birds meant to be reared by hand should be taken at an earlier age, for their little wills develop with their plumage. So I found mine very obstinate. They got it into their heads that the nourishment I offered them was medicine, and would not open their mouths. When a child is fractious in the same way, you can hold his nose and his mouth must open, but Bulbuls have not tenable noses. However, I managed to get a good quantity of food stuffs introduced into them one way or another ; but my birds pined, and I soon saw that they meant to die. The only thing to do was to replace them in their cradle, where their parents made great jubilation over them. Within two days, as I was walking in the garden, I found one of them on the ground, in robust health and trying to fly. I took him under my protection again, for I am a benevolent man and was sure the crows would find him. This time I tried a diffe- 
rent system. I got my ingenious chupprassie, Yakoob Khan, to make a rough cage of bamboos, and in this I hung my little Bulbul among the convolvulus which overgrew the verandah, where his parents could visit him and bring him dainties. This they did all day. Now it was a soft green grasshopper, now a fat mantis, with the legs and hard parts stripped off. They made an absurd amount of fuss, bo-peeping at me through the leaves and calling out to one another to beware. I knew they were trying to poison the innocent mind of their little son against me. But I foiled their designs. I fed him when they were away and treated him kindly and so completely won his confidence in a week that I had only to whistle from any part of the house and he would answer me. So all went well until one Sunday morning, when I was sitting reading and my little pet was hanging in the verandah. Suddenly I heard shrieks of agony from his cage, and rushing out, found him with his back against the bars and his wings stretched out, like a butterfly pinned to a board. I looked behind, and there was the neck of a snake, stretched like a cord from the trellis to the cage. The abominable reptile had insinuated its head between the bars and caught the bird by the back, and 
was trying to drag it out. I lifted my foot and gave it a frantic kick, which must have sent the snake quite out of this world, for it was never seen again. Then I hastened to examine my pet. His poor little back was flayed. The double row of small sharp teeth on each side of the snake's lank jaws had raked off both feathers and skin. He revived towards evening and tried to look cheerful, but sank and died next day.

I grieved for that Green Bulbul more than I generally do for lost pets. I almost said,

"Love not, love not; the thing you love shall die."

But no! I cannot accept that sentiment. It is moral imbecility. I believe that the words of the clear-eyed and sound-hearted poet who has gone from us are true of all bereavements, little and great-

"I hold it true, whate'er befall, And feel it when I sorrow most, 'Tis better to have loved and lost, Than never to have loved at all.'

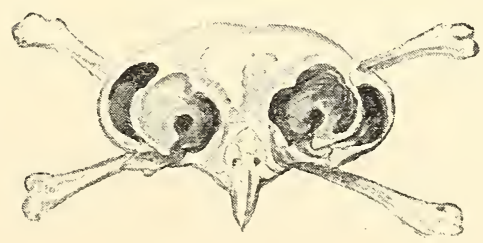




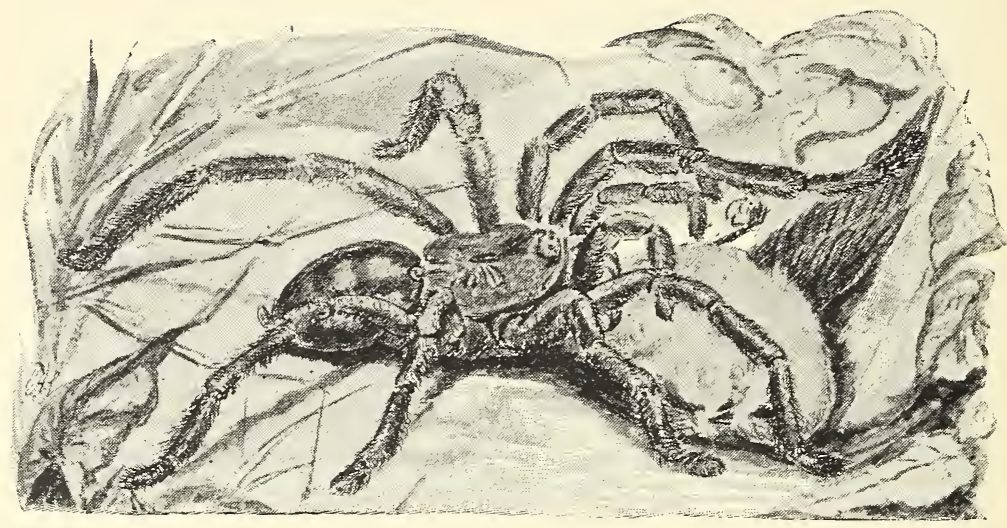

Chapter XV.

S P I D E R S.

THE spider season has begun, and I find myself fast drifting into a spirit of acerbity and reprehensible tempers. With the best intentions and a heart duly exercised, I hope, in benevolent feelings towards my fellow-creatures, I am not proof against grave and sudden provocation. Such provocation occurs when an unseen, but exceedingly tough and glutinous, string catches me over the bridge of the nose and across both eyeballs, and forbids me to advance till I have severed it with a hunting knifc, Or 
else when, as I thread my way along a narrow jungle path, a soft and filmy web embraces my face and ears, and the over-fed spider who spread it trickles down my nose and over my lips and gets entangled in my beard.

At such times one learns that one is only human, and virtue has a rare triumph if the spider does not learn it too. The worst of it is that theoretically I hold spiders in great esteem both for the work they do and the manner in which they do it. Alas! theoretical and practical benevolence are not like the Siamese Twins, and I never see an Englishman distinguish himself in the press, or on the platform, as a friend of the natives of India, without wanting to know how he treats his servants and putty-rvallahs. Believe me, it is often a good thing for the cause of political philanthropy that they cannot be put in the witness-box. But if I were on the press I would interview them.

To return to spiders. Why must they spread their snares right across every track and make all my choice paths impassable? Here again I suppose that reason is on the side of the spider, though passion gets on mine. She has no intention of snaring me, but she knows that almost every denizen of the forest, from the tiger to the 
butterfly, will use a path if it can find one, and so she spreads her nets where the moth and the beetle will pass, just as we set our traps in the run of the beast we wish to catch.

Yes, the fact is, we all seek our own, and our interests are not the same, so we jostle one another as we push along, and the weaker goes to the wall. Do not mistake my meaning. In this instance the spider is the stronger, and it is I who go to the wall. But even the trodden worm will turn, and I do turn sometimes on that spider. But I confess I am at a loss what to do with him. cannot put my foot upon him: he is too fat to be "squished," as they say in Surrey, without a feeling akin to mal de mer. What I should like to do would be to put him in spirits of wine and make him a specimen. And, indeed, I did at one time prcvide myself with a supply of small glass tubes, and determined to devote myself to the study of spiders. Casting about for guidance on a subject so unfamiliar, I learned that there was practically no book which would be of any use to me, but that there was one great living authority to whom I might apply. He resided in Sweden and usually wrote in Latin. 
This was like referring me to a Mahatma in Thibet. Is there no one else, I asked, in the world, who knows something about spiders? Then I was told that there was indeed one other gentleman who had devoted himself to the subject and might be able to help me. He was an English clergyman. I wrote to him at once and received a very kind note in reply, telling me that he was at present occupied with the spiders of Africa, or South America, or some other place, but hoped in four years' time to be able to turn his attention to those of India. This would not do either. My interest in no subject will keep fresh for four years. Finally I got hold of a manuscript synopsis of the classification of spiders, and copied it out for myself. From this I learned that the Araneinae are divided into seven suborders, as follows :-

I. Orbitelarice, those which make a geometrical snare.

2. Retitelarice, those which make a loose and unsymmetrical web.

3. Tubitelaria, those which inhabit holes lined with silk.

4. Territelaria, trap-door spiders.

5. Laterigrade, crab spiders-namely, those which live about our walls, without webs, and throttle cockroaches. 
6. Citigrade, wolf spiders, which hunt among grass and bushes.

7. Saltigrade, jumping spiders.

This seemed admirable, and I went deeper into the subiect, that I might know how to identify any strange spider. Taking up the seventh sub-order, I found that it was divided into two families-the Eresoida, in which the cephalo-thorax is convex, and the Attoide, in which it is flattened. So if I get a jumping spider, I said, with its cephalo-thorax flattened, it shall go into the Attoida. But the Attoide are again divided into two groups, those which have the cephalic portion higher than the thoracic portion, and those in which it is not higher. The second of these is again divided into those in which the eyes are arranged in a quadrangle longer than it is wide, and those which have them arranged in a quadrangle wider than it is long. Two further sub-divisions follow, and then you come to the genera, which are distinguished in this way. Ballus, ocular quadrangle distinctly wider behind than in front; Marpessa, ocular quadrangle scarcely wider behind than in front. At this point I began to understand how it is that the world can only support one authority at a time on such a subject, and for myself I decided to cultivate the 
acquaintance of spiders without subjecting them to the rigours of classification.

I wish I had pursued this purpose with more energy, for the subject is a very fascinating one. If you feel inclined to take it up, now is the time. As the crops which have been silently growing for months are now ripe for the sickle, so the insects which have been feeding in the obscurity of grubdom are producing a teeming harvest of winged things; and the rains, which make havoc of the spider's toils, are now nearly over. So all at once they appear and spread their snares in every likely spot. Where do they come from? Our abysmal ignorance again! I do not know, nor can I find anyone who does.

The most conspicuous among them is a gigantic brute, whose body, streaked with green and yellow, measures nearly an inch and a half in length, while her slender black legs will easily span half a foot. She must have taken some time to grow to that size, and we may safely assume that she was born last year, but, if so, she has been in hiding for the past six months. Now she appears suddenly and spreads a great web across the road, fully three feet in diameter, suspended from cords like tent ropes, made fast to distant trees. I speak of her in the feminine gender because she is the lady 
of the house. If you search the premises you will find her lord, a paltry thing of a reddish colour and about one quarter of an inch in length. He is Mr. Mantalini and lives entirely on her earnings. She would assuredly eat him if she could catch him, but he is circumspect and keeps out of her way. Besides Mr. M. I have sometimes found a small silvery spider of a different species about the outskirts of the web. This, I imagine, fills the place which in our system is taken by the pariah dog, who sneaks about our compound, filling his shrunken stomach with what we throw away.

Judging by the size of this great spider and the strength of her web, I used to think she might easily catch a Sunbird, or a small Tree Warbler, but I find she is not nearly so formidable as she looks. In fact she is a "feckless" creature. When a moth or a beetle gets entangled in her web, she hurries down, and seizing it with her jaws, tries to haul it up to her seat; but if it is strong enough to resist this treatment, it may easily break away and escape.

There is a far more deadly spider not half her size, which spreads its beautiful circular net in our gardens. In the centre is a round space, with four little strips of white 
"feather stitching" arranged in a square, to give firm hold to the feet of the spider, which always rests with her eight legs extended in four pairs, like a Roman cross. The unlucky insect which once touches her net has a poor

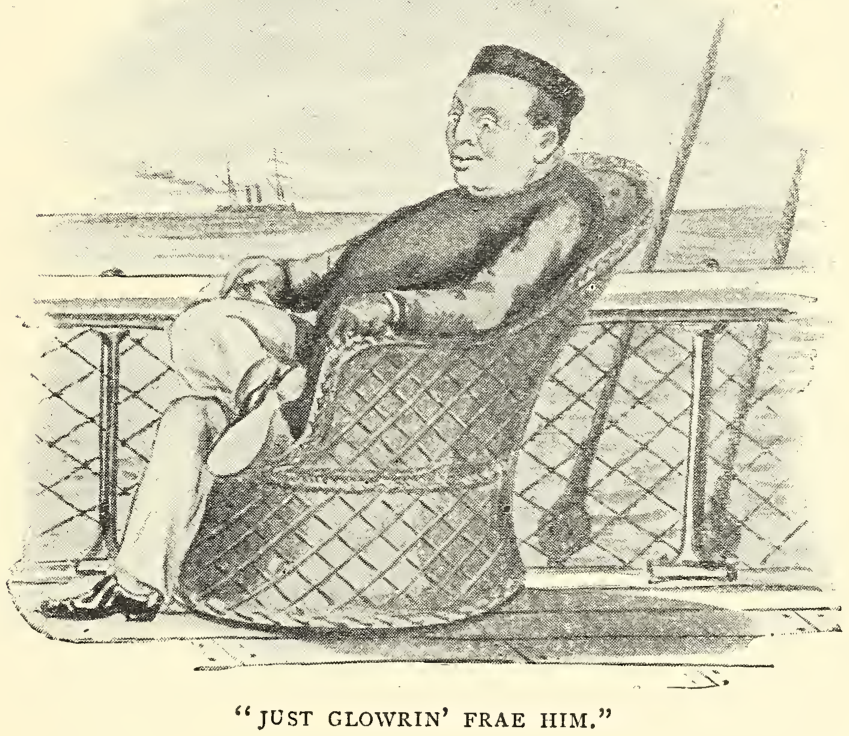

chance of escape. She makes no attempt to scize it, but simply fastens an end of silk to its body, and then spins it round with her hind legs at such a rate that, in a ferw seconds, it is as neatly done up as a reel of Taylor's 
No. 6, and cannot move a limb. In this position she leaves it till dinner time.

I have never been able to satisfy myself whether spiders are gifted with much intellect. To be able to sit all day doing nothing does not seem to argue an active mind; but yet, when I once enjoyed the privilege of making a sea voyage in the company of one of the most renowned of Baboo orators, nothing surprised me so much as his wonderful power of sitting on deck all day doing nothing and staring nowhere, just "glowrin' frae him." I have never seen any vertebrate animal that could do the same except a cow, and he beat the cow; for it amuses itself chewing the cud, but he did not even chew beetles like the Regent of Manipur. I make no doubt that, all the while he looked so vacant, he was forging, in the workshop of his brain, those thunderbolts with which he would ere long scorch his rash antagonists.

So may not the spider, in its long hours of seeming idleness, be evolving those geometrical figures which excite our admiration far less than they should? This also is possible, as Rudyard Kipling has said. But be her intellectual endowments great or small, the spider is without an equal in her own art, and the daily weaving of her 
evening or morning web is a sight of which I never tire. Yet I confess with shame that to this day I do not know how she throws the first line from tree to tree. The commonly received view is that she first serves out a line so thin that it floats on the air till it touches a tree, or some other object, and sticks, whereupon the spider draws it tight and travels along it with a stouter line. The proof for this view is that it must be so, or else how is it? And at one time this argument was enough for me. Then I read a paper by a great naturalist who had become a chela under Madame Blavatsky, in which he stated that the power of suspending the laws of gravitation, which is acquired by some men through a long course of selfabnegation and austerities, is innate in many birds, enabling them to sail through the air without effort. Still I scoffed-how easy it is to scoff-but at last I was cured.

"Namque Diespiter,

Igni corusco nubila dividens

Plerumque, per purum tonantes

Egit equos volucremque currum."

The thunderbolt fell in this way. Wandering in the Tanna jungles with a scientific friend, I noticed a lovely little silvery spider and resolved to specimenize it. Inclosing it in my hands, I was about to bottle it, when it 
slipped through my fingers and went off like a snipe. There was not breeze enough to stir a feather and the spider had no wings, but no witch on a broomstick could have ridden the air with more ease. We both darted after it and caught it again, but it gave us the slip once more and sailed away. We stood aghast and looked at each other. Then I proposed to my friend that we should give an account of the affair at the next meeting of a certain learned society. But he would not hear of it. I offered to be spokesman, but he would not even promise to stand by me.

Perhaps he was wise. I have heard a story of an officer who was recounting at the Mess table an almost incredible adventure in which he and a brother officer had been engaged. As he proceeded he saw an eloquent smile form itself on the features of one after another of those who listened to him, and a low whistle came from the extreme end of the table. Vexed at being doubted, he protested that he had not exaggerated a single incident, and he appealed to his friend to corroborate what he had said. But the friend, too, smole a smile, and the narrator was crushed. Boiling with rage, he waited for an opportunity of finding his friend alone and confronted him. 
"What did you mean," he cried, "by treating me in that way before all those fellows? You know that I was saying nothing but the truth. Why did you not speak up ?"

"My dear fellow," replied his friend, "you saw that they all put you down for a liar. Why should you wish them to put me down for a liar too ?"

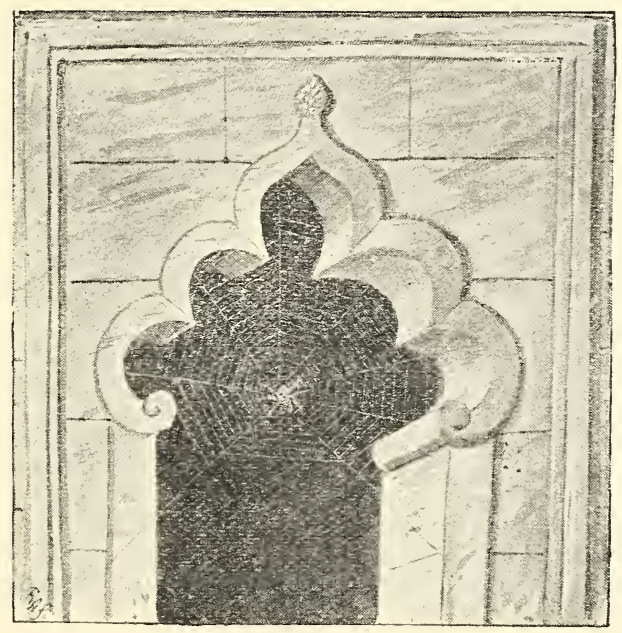




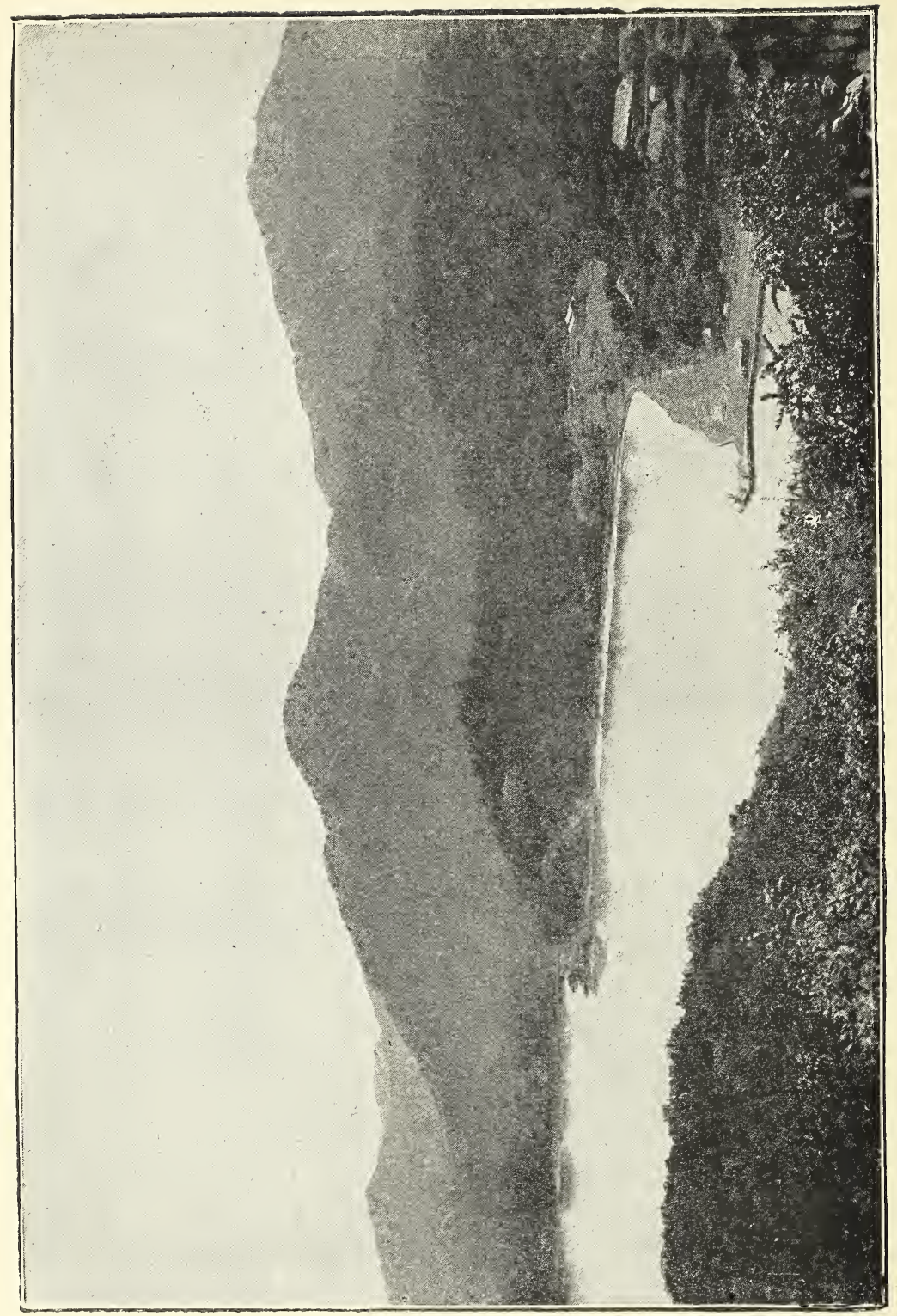




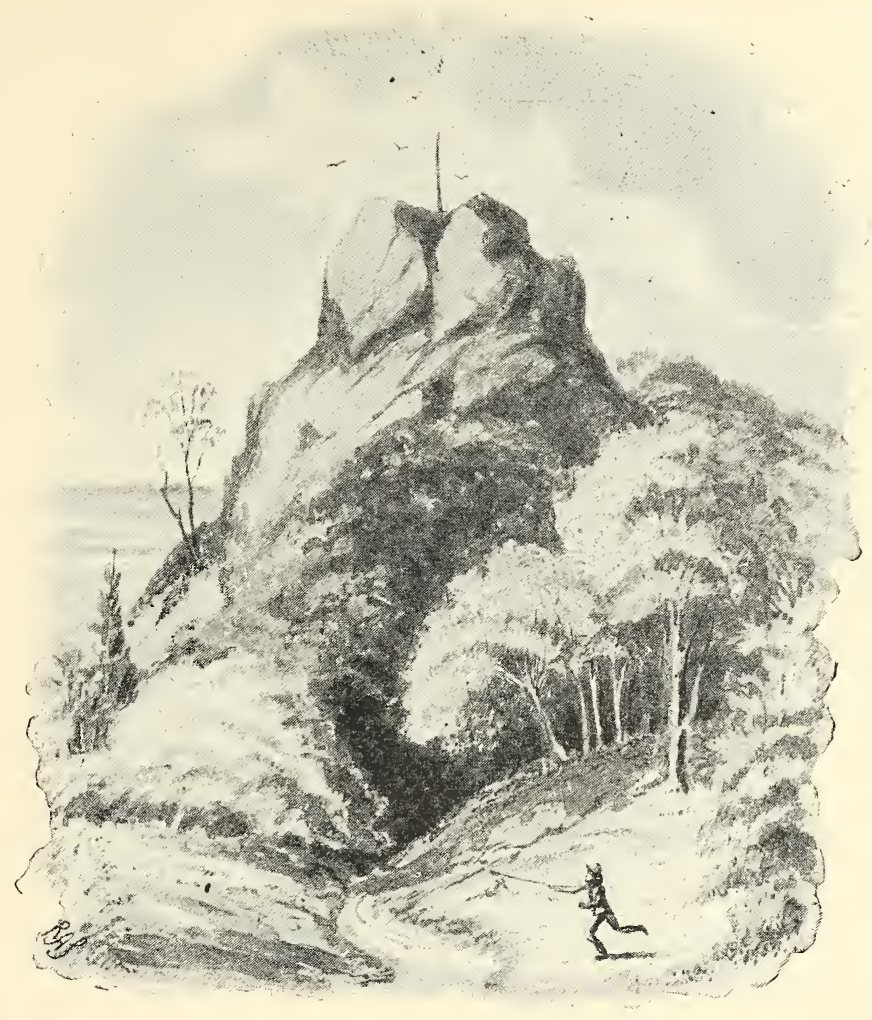

Chapter XVI.

\section{A MOUNTAIN TOP.}

WITHIN an hour's walk of my house there is a mountain which, rising honestly from the level of the sea, reaches a height of I,850 feet. Its slopes are densely clothed with varied forest, sometimes weirdly silent, sometimes ringing 
with the ever-changing, sweet, harsh, loud, low, tinkling, rasping notes of the Racket-tailed Drongo, the mellow call of the Oriole, the harsh cries of the jungle Parrot and the angry objurgations of the Black-faced Monkey. On the granite-tipped peak which just pierces its green mantle, a few large boulders are balanced in grotesque positions, proving that Hanooman, the monkey god, rested here on his expedition to Ceylon. Wedged in among the rocks is a tall staff, said to have been planted there to commemorate a pedestrian feat by a certain renowned Colonel, who bids fair to take rank in the traditions of the district with the monkey god. Where Hanooman sat in his day and the Colonel in his, there sit I; for it is my day now and this peak is the great basking place of butterflies.

On a blazing October day, at the fashionable hour of noon, you will find representatives here of almost every noble family in the country. The Four-tailed Pashas take the first place of course-Charaxes athamas and fabius and imna, perhaps even schreiberi. Each claims an outstanding branch of some tree with shining leaves as his station, from which he will dart out from time to time to chase away a rival, or display his power of wing, returning again 
to the very same leaf. Euthalia lubentina, surely one of the loveliest of living things, is rarely wanting, though its relations lepidea and evelina prefer the shades below and garuda is getting drunk at a pot of toddy in my garden. The handsome Cynthic saloma opens its broad wings to the sun, and two or three species of striped Athyma and not a few dazzling "Blues" swell the gay assemblage, and there is always a ragged and envious old Hypolimnas bolina, venting its spleen on the young and happy, chasing the small and attacking the great. Two deceivers of the swallow-tailed clan, dissimilis and panope, sail about over the trees with the indolent air of the slow-winged Danaina, which they impersonate; but they quarrel, one flies, and off they both go at such a rate that the eye cannot follow them. Other magnificent swallow-tails come past now and then, but they are not baskers and do not stay.

Each of these recalls a red-letter day in the note-book of my memory. Shall I ever forget that forenoon when I caught my first imna? How it persisted in perching just a foot beyond the reach of my net. I jumped like a kangaroo, but missed it. It generously gave me another chance, and of course I missed it again. It grew triumphant as I grew decrepit, and seemed to smile down 
on me as I grinned at it, my head resting between my shoulder-blades and my neck feeling like the stalk of a fruit which is ready to drop from the tree. At last an old bucket from a deserted house, turned upside down, added the necessary foot to my stature, and in a few minutes more those shining brown and black wings were flapping fiercely in the folds of my net. Never again will imna afford me that ecstasy, nor any of those I see around me to-day. I must be content with the more peaceable pleasure of watching them and chewing the cud of past joys.

One remarkable thing about this assemblage is that it is attended only by males. The females avoid places of public resort, and those of the higher castes appear to be strictly purdah-nishin. What would I give to find the zenana of imna or schreiberi! Another remarkable thing is that when you do chance to find the caterpillars of any of these basking butterflies, it is often at the foot of the hill. What prompts them to forsake the haunts of their childhood and throng the mountain top? Do they enjoy the freshness of the air at this great height, or has the beauty of the scenery charms for them too?

Do not assume that questions $f$ this sort are meant for 
jokes. The greatest naturalists of this century have suggested, without any joke, that the loveliness of butterflies has been evolved by sexual selection, which would imply a faculty in them of discerning and enjoying what is beautiful in colour and form far above what average mankind has ever attained to. However, there is another possible explanation of their presence here. I am inclined to believe that many butterflies are fond of soaring in the air, like birds of prey, though their small size makes it impossible for us to see them, and that they come down to the peaks to rest. As Euplac core sails up and down a shady lane and the dusky Satyrs dance round the root of a tree, so, I imagine, do these bold spirits disport themselves in the blue empyrean.

There can be no doubt that fancy flying is an exercise in which those animals which are fitted to excel in it find great delight. To birds that can sail, like eagles and vultures, a windy day is as frost to skaters; and who has not seen the kites collect to enjoy the great gust that precedes a thunderstorm? Others sport with eddies and currents, where the wind is turned by a steep hill or a high tower. Years ago I used to notice the swallows amusing themselves in this way at the Bund Bridge in Poona. The 
wind blew hard across the bridge, whistling under and over the stone balustrade, and the game was to pop behind this

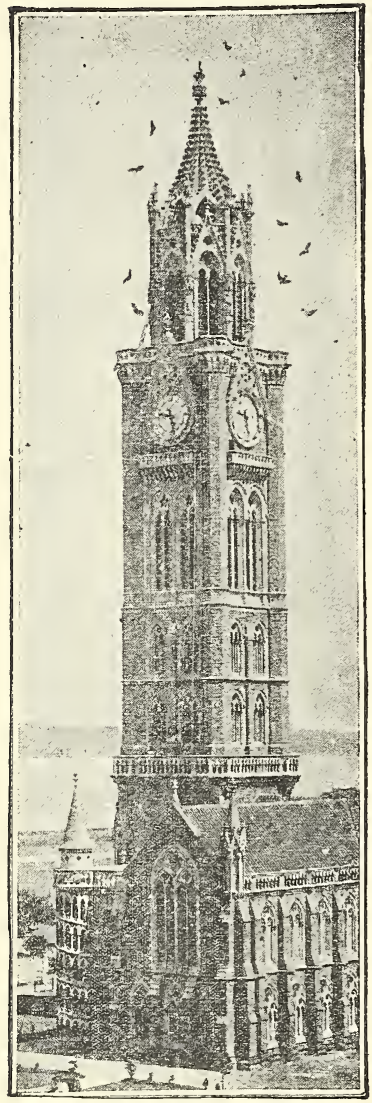

CLOCK TOWER, BOMBAY UNIVERSITY LIBRARY. shelter and sail close under the stone for twenty or thirty yards, then to rise suddenly into the gust and be blown away like chaff before the wind. All the swallows knew how to do it and followed one another in line. Doubtless it goes on to this day, one generation teaching another.

Every Dolphin in the Mediterranean now knows what fun it is to get in front of a steamer, close to the bow, and disport itself in the turmoil of the cloven water. Even the abandoned Crow, like the Coster when he's done a-jumping on his mother, finds gentle joy in exercises of this kind. In Bombay there is a regular Gymnasium on the top of the University Tower, where, on a windy day, 
many crows come together and perform really graceful evolutions.

Another example came before me just now, as I sat on this very peak, and perhaps put my mind into its present train of thought. Far out to sea I saw a large bird of prey, too dark to be a sea eagle or an osprey, going through a strange performance. Closing its wings at a great height, it dropped like a stone, as if on some doomed fish, but before arriving at the surface of the water, it turned its course so neatly that the impetus of its fall carried it up into the sky again. After toboganning in this way for some time, it made for land and came straight towards me, and lo! it was Neopus malayensis, the Black Eagle. I never could have suspected this gentle poacher of going out to sea for exercise. Was it afraid of breaking its bones if it tried the same thing among the hills, or was it mocking the Sea Eagle and pretending to catch fish? How smoothly it sails now just over the tops of the trees, rounding the hill, rising or sinking, without one flap of its sombre wings. It is so near that my friend and I can see its yellow face and almost count the number of its quills, upturned and spread like the fingers of a hand.

Thus we take note in silence, or dreamily chat of what 
passes before us in the beautiful panorama spread around and below, when a whitish butterfly, with dark veins, flutters gently past, like a moth, and settles on a leaf with wings half open. Euripus! yells my companion and springs to his feet. Euripus! I yell in reply and spring to mine. We both grasp our nets and tumble off the rocks in a heap. But the butterfly flies gently to another tree, where it is out of reach.

We post ourselves in two likely places and send a man to shake that tree. It flies to my lucky friend's station and perches on a prominent leaf. He believes in a bold policy and goes smartly up, intending to whip it up before it has time to think. But it takes no time to think. It just flutters across to my tree.

I believe in a cautious policy and advance like a cat. The fingers of my left hand are spread like an umbrella frame, and I must be making faces which would gain me admittance to any lunatic asylum in the world, but my friend does not laugh, for he is not looking at me, only at the Euripus. I can see its antennæ, nose and eyes, looking over the edge of the leaf. I am near enough now, for the staff of my net is ten feet long. Imperceptibly, like a tree gowing from below, the green bag 
moves up till the butterfly is exactly in a line with its centre, and then I give the word to myself-one, two, three, off! But the butterfly is off first, and without showing the least alarm, settles a few feet further away, where a stout branch will effectually obstruct the net.

Pelt it with stones. What a lot of pelting it takes! In fact, nothing appears to start it except a butterfly net. At last a good sized stone actually knocks it off its perch, and it flies clean away. We must just wait patiently; it will certainly return. So it does in half an hour, and the second act of the drama is very like the first. So are the third and fourth. At last, with our necks dislocated, our faces toasted like cheese for a rat trap, our mouths dried up like a potsherd, and our minds dejected and embittered, we shoulder our nets and trudge down the hill.

P.S.-That Euripus consimilis has a pin through its thorax. It tempted fate again next day and the fifth act of the drama closed with a tragedy.

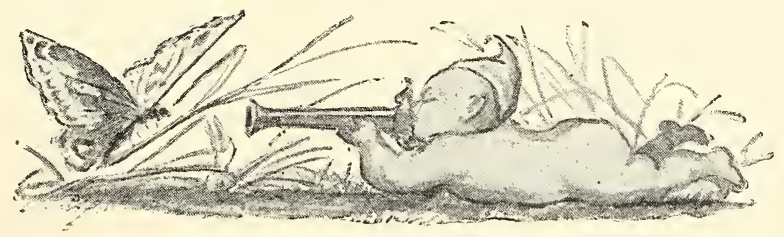




\section{Chapter XVII.}

\section{THE RED ANT.}

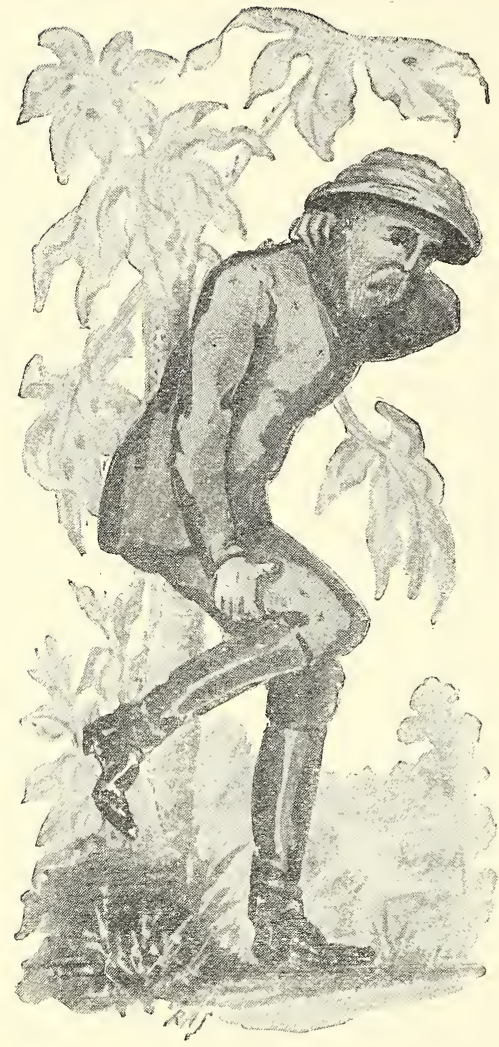

I WONDER if there is any

living creature which can be looked at from so many points of view as the Red Ant, or Yellow Ant, as some prefer to call it. It is, in fact, neither red nor yellow, but of a light, sherry-brown colour, with fierce black eyes, and long curved jaws. The point of view from which it has most often fallen to me to consider it may be described in this way. Hot and tired, you sit down carelessly on a log or rock, which, for some strategic 
reason, has been garrisoned by a wing of a regiment from a populous settlement in the very tree which shelters you from the sun. Or else, threading your way along a jungle path, you are obstructed by the tough branch of a wild vine, which joins two trees and is used as a bridge by the ants which occupy both. Long before you reached it they were aware of your approach, and were dancing with excitement on the point of every prominent leaf; so you have hardly touched it before a hundred have thrown themselves on your arms and body. One or two begin at once to bite your clothes. These are the young and inexperienced. The veterans make straight for certain points of which they appear to have instinctive knowledge, as, for instance, the back of your neck, just under your collar. Arrived there, they plunge their sharp jaws into your flesh, then curl their bodies round for better purchase, and drive the weapons home with a savagery which is simply appalling. When you pull the ant off, its head remains, for it is more firmly riveted to your skin than to its own neck.

For many years this was the only point of view from which I had regarded the Red Ant, to which I attribute 
the fact that my feelings towards it have never been friendly. One day I saw it in another light. I will quote an account of the affair from the Journal of the Bombay Natural History Society. I can vouch for the accuracy of the account, though modesty forbids me to tell who wrote it :-

"One evening I found that a countless multitude of Red Ants had collected about two trees close to my tent and were making a thoroughfare of one of the ropes. I thought it best to discourage this, so I got some kerosene oil, the best antidote I know for insect pests of every kind, and dipping a feather into it, began to anoint the rope, thinking in my simplicity that they would not like to cross the oil and would be obliged to find another road. There was a perfect storm of indignation. They rushed together from both sides and threw themselves on the oiled feather in the spirit of Marcus Curtius. They died, of course, but others came on in scores, panting for the same glorious death, and I had to give up my idea of dislodging them by kerosene. I determined to try tobacco, for I had always supposed that man was the only animal which could endure the smell of that weed. I lighted a cheroot and steadily blew the smoke where 
they were thickest. Never in my life have I seen anything like the frenzy of passion which followed the first few puffs. To be attacked by an enemy of which they could not lay hold seemed to be really too much for them. In their rage they laid hold of each other, and as a Red Ant never lets go, they were soon linked together by head, legs and antennæ into one horrible, red, quivering mass. I left these, and going to another place, offered the end of my cheroot with about an inch of ash on it. Several seized it instantly. The heat killed them, but others laid hold of their charred limbs, and by their united strength they positively wrenched off the ash, which remained hanging from the tent rope by their jaws, while scores hurried from both sides, with fiendish fury, to help in worrying it. I then presented the hot end. The foremost ant offered battle without a moment's hesitation and perished with a fizz, but another and another followed, and I saw plainly that I was beaten again, for the cheroot was going out, while their fury only burned the more fiercely. I retired, and a fte taking counsel with the captain of my guard, made a torch of straw and patiently smoked them to death all along the rope Then I attacked the root of the tree, where they 
were thickest, and left nothing but a black waste. Half an hour later fresh myriads were carrying off the charred remains of their comrades. They took them up the tree towards their nest, whether for food or burial rites I cannot say. It was now getting dark, so I gave up my enterprise ; but before going to bed I brought out my lantern and found them calmly passing up and down my tent ropes as before. I had done everything I could, short of burning down my tent, and they remained masters of the field."

This changed my feelings a little. Forced admiration now mingled with my aversion. It seemed to me that the Red Ant had acquired that power which overcomes every other power in the universe, the power that is born of utter self-effacement. I will not say self-denial, for the religion of society has perverted that grand word to strange uses. A man speaks of practising self-denial if he refuses meat in Lent; as if denying beef and mutton was the same as denying self. So we must find another word for the original idea. Of course I do not mean to assert that ants have attained to self-effacement; for how do I know that they have any self to efface? But, looking at "hat we can see of their outward life, I think we must 
admit that it is a genuine socialism, in which the community is everything, the individual nothing, either to himself or the rest. Hence it is naught to them that a thousand die in the common cause. Indeed, I almost think that they regard such an event as a national gain, being troubled with the difficulties of over-population like ourselves. This is certain, that if you are plagued by ants and try to frighten them with death, you will only make a fool of yourself. I know, for I have often done it. The more you kill, the better pleased they are. The rest hurry down in re-doubled numbers to carry off the corpses, which I am sure they do not waste, but preserve for the food of the people. Surely this is rectified spirit of socialism.

Next I saw the Red Ants constructing one of their wonderful leaf nests, and admiration began to preponderate over aversion. It was in a tree with very large leathery leaves, and the first thing to be done was to draw two of these leaves together. Beginning at the point where they were closest, a number of ants seized one of the leaves with their teeth and the other with their hind feet, and began to pull Further on an ant seized one leaf with his teeth, then another ant seized the first by its 
waist, and reaching the second leaf with its hind feet, began to pull. Further on still the chain consisted of three ants, or four, or five. As their united strength drew the edges of the leaves slowly together, others were busy securing them with strong cords of silk, which they tightened as the work progressed, till the leaves were firmly joined,

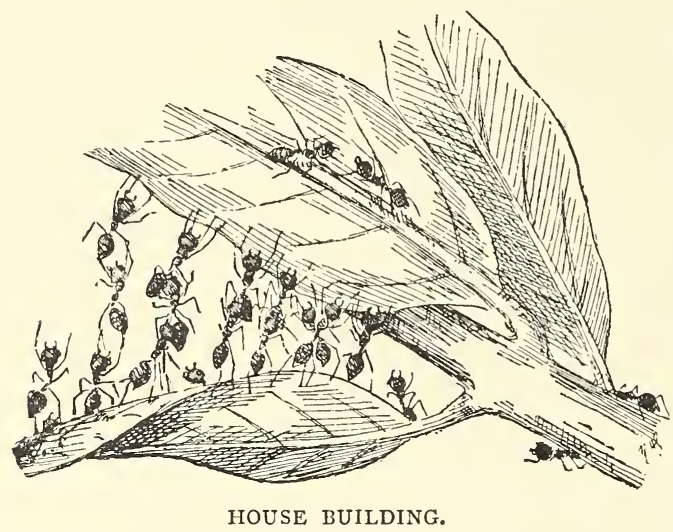
edge to edge, and formed the walls of the central chamber.

I have often watched the operation since. Leaf follows leaf in the same manner, gauze curtains are spun across all open spaces, and partitions of white silk divide the chambers and passages, making a noble mansion, or say rather a populous city, the capital of a great and terrible people. Smaller towns arise on the branches round about, and stables, or pens, are built for the accommodation of the State cattle, which consist chiefly 
of aphides, or plant lice, of a white, fluffy sort, known to gardeners as "mealy bug." These are their sheep.

But they keep cows too, and it was watching the management of these that finally changed all my feelings towards the Red Ant. For I am a collector of butterflies, and the finest breed of kine is the larva, or caterpillar, of the largest and most dazzling of all our "Blues." This caterpillar grows to more than an inch in length and has on its back a gland that yields a certain liquid, which you may call honey, if you please, or milk. For our present purpose let it be milk. It is palatable and nutritious and will sustain the life of a Red Ant without any other food. The little animal that yields it is quiet, docile and easily domesticated. What wonder that it is held in high esteem!

The tree on which it is found is occupied more than most trees by great colonies of Red Ants, and wherever they find a cow, they take possession of it. They do not inclose it, but let it graze at will and appoint guards over it, which never leave it by night or day and guard it from every danger. If you take it away, they will go with it and stay where you put it. At short intervals all through the day they milk it, with a skill and gentleness 
which are wonderful to behold. One of the guards caresses it with her (they are all Amazons) antennæ on the head, and up and down the sides, till she comes to the milk gland. When she touches this a drop of clear liquid appears, which she instantly sucks up.

This looks selfish, but it is not. Her pail is in her body, and when she has filled it, she will carry her precious burden to the State nurseries. In time the caterpillar arrives at maturity and changes into a chrysalis. It can yield no more milk after that, and you would not be surprised to hear that the ants killed and ate it. But they do no such thing. The guard watches over it still for ten days, until the butterfly has emerged and flown safely away.

Take this fact and think over it. You could scarcely spend an hour better. Say it is gratitude, such as sometimes moves us to pension an old horse that has served us long and faithfully. Or say it is policy, like that on which we act when we institute a close season for game. Say what you will, in short, but think your meaning out, and you will be a more reverent and a humbler man than you were.

How these communities of ants are founded is a ques- 
tion which has long puzzled formicologists, whether they tried to find the answer by observation in the field, or to evolve it from their inner consciousness at home. For a young queen does not leave her home, as among bees, with a retinue of many hundred workers, but alone, and unless she can gather a following of deserters from other nests, she must continue alone until her own children are old enough to be her attendants. But till then who is to tend them? It was thought impossible that she could soil her royal hands with domestic drudgery. We now know, however, that in the case of the Red Ant at least this is what does happen. She lays a few eggs and broods over them like a hen, then contrives somehow to feed and guard the helpless grubs till they develop into worker ants and are able to take all household cares off her hands.

Only a few days ago I myself saw a solitary queen on a leaf (she had no one to build her a house), with eight children around her which had just come of age, and a few more still in the white and limbless state of infancy. A curious feature of this little family was that the mature ants were only half as large as they should have been. I had often noticed similar dwarfs before, chiefly in young nests, and had wondered why they were so undersized. 
Here was the explanation of the mystery. These little unfortunates are the offspring of a young queen, who is ignorant of nursing and has nobody to help her: they are stunted of course by want of food and mismanagement in infancy.

The queen of the Red Ant, the mother of barbaric hordes, is herself a mild and handsome insect, nearly three quarters of an inch in length and of a fine green colour. From her no doubt the species obtained its name of Ecophylla smaragdina, which, freely rendered, means the Emerald Inhabitant of Leaf, Houses. But I am told that in New Guinea the worker also is green. Why it should be green there and red here is a curious question. It has been suggested that the red colour is protective on the bark cf mango trees, at which I am not surprised, for there are men who would suggest that the Union Jack is coloured red, white and blue to elude the observation of the enemy.

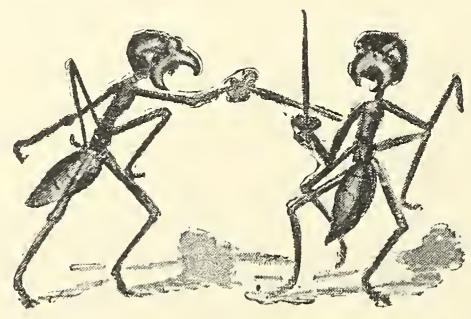




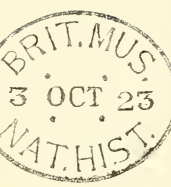




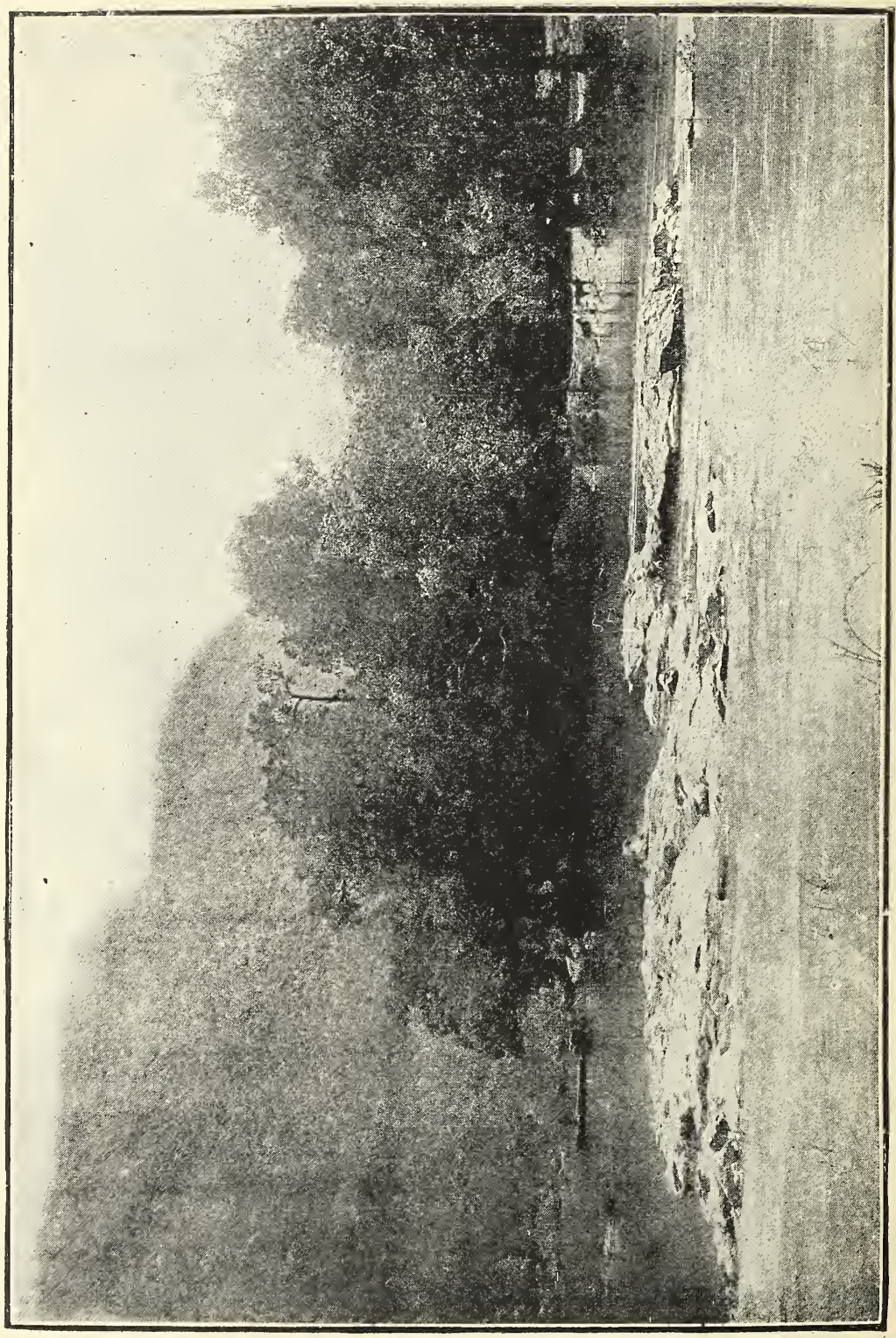




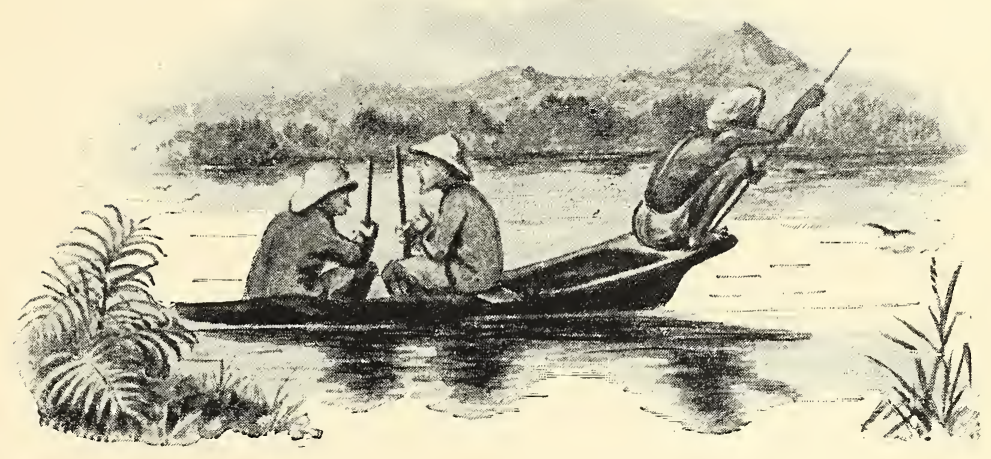

Chapter XViII.

BASWESHWAR.

TO the south of my camp (for I am in camp now), on the other side of the river, runs a range of high hills, one of which is crowned with a great conical mass of rock visible for many miles. It must reach an altitude of about 2,000 feet. This rock is the abode of the god Basweshwar, who must live a very secluded life. Once a year, however, in the month of December, he holds an "at home," which is very numerously attended by pious Lingayets and also catholic-minded persons of other persuasions from the valleys round about. My friend and I decided that, for 
many reasons, it would be a proper thing for us to visit this place. The ascent was said to be stcep and very difficult, so how could two men, honourably proud of their legs, prove the quality of those limbs better than by trying it? A second reason was that the place was said to have been visited by sahebs only once before; and if a third was required, there could be little doubt that the path to that peak would take us through many a "forest's shady scene," and so on to the end of the quotation, which is unfortunately too hackneyed for repetition here. Among the things that own not man's dominion are one or two, some say three, tigers, which have for years past successfully disputed even his right to shoot them. They will kill a couple of fat cows, eat the whole of one and a leg of another, and positively refuse an interview to anybody who calls them to account. A Brahman gentleman, who paid me a complimentary visit to-day, informed me that the people of his village had had the pleasure of keeping one of these tigers for some months for an enthusiastic shikari of the Forest Department, but that he had failed to bring it to account. The Brahman gentleman was evidently facetious, if not ironical.

Well, we started for the shrine of Basweshwar this 
morning. Having crossed the river in a lop-sided doney, hollowed out of an unshapely tree, we were met by the parish clerk, who presented us each with a lime in acknowledgment of our suzerain rights, and committed us to the guidance of the patel. The patel was a dark man, tall and sinewy, wearing in his left ear a gold earring and in his right ear two. He was reserved and had that in his face which told he could keep his own counsel. His counsel is suspected to be the counsel of the wicked sometimes; but with that we had nothing to do this morning. He spoke a language for which he might have taken out a patent, for it was distinctly a new invention. However, we could command three languages between us, and had found by experience that equal parts of the three was the best mixture for common use, so we got on fairly well.

Starting from the river, we marched along the Malhapur high road for some time, then took a footpath to the right, through rice-fields delightfully mixed with patches of forest and low hills and murmuring streams. The very place for a jungle cock with his bevy of comely hens; but that proud bird's cheery crow is seldom heard here. Snares and nooses are laid in his favourite walks, and the unlicensed gun, I fear, lies in wait for him at mány a point. 
I suspect the dark patel knows something about that. But of birds which are not game the trees were full. Criniger, the Yellow Bulbul, with his loud and hearty voice, was everywhere, and the Green Bulbul and the bright little Bronzed Drongo and the Racket-tail and others more than we could stop to note. From one of the loftiest trees a great Hornbill went off at our approach, his neck stretched rigidly out, his monstrous bill open, as if gasping with the effort to carry his great weight through the air, and the strong flap of his wings making a strange noise in the sky.

We now began to ascend a small preliminary hill. We stopped for a moment to admire a curiously shaped and brightly coloured spider. Its web was a beautiful piece of work, and in the centre there was a white silk mat, on which it reposed. But when we looked at it too closely, it suddenly put itself on the other side of the mat. We looked round on the other side, and it was back on this. The threads which radiated from the mat were far too close to let its body pass between. They were elastic, of course, and it could easily have pulled them apart with its feet and struggled through; but it did not seem to do this, or indeed to do anything. It simply ceased to be here and was there, like a conjurer's shilling. However, we had no 
time to spare, so we pushed on. Ere long we were hypocritically looking about for a spider, or any other excuse to stop and collect a little breath; for now the path led straight up the side of the hill at a gradient of $I$ in $I$. Conversation stopped, and we husbanded our brcath, like wise men, for our real needs. Silence is never more golden than when you are climbing a steep hill.

Everything else was as silent as we, for here there were no birds. The trunks of the trees rose like tall pillars, sustaining a leafy roof through which the rays of the sun could find no way. The air was cold and still, as in a vault. There were no butterflies either, except Melanitis ismene, lover of darkness, as its name seems to say. It flitted about everywhere, dressed in all the tints of the fallen leaves, or, alighting among them, fell partly on its side and was one of them. Long columns of the Military Ant, the fiercely stinging Lobopelta, crossed the path everywhere, bent, without doubt, on marauding raids into some populous termite country. They cannot bear the sun, and generally return from their cxcursions when the day dawns; but here the day does not dawn.

One other notable creature we saw, a gigantic black wasp with rusty wings, "of the thickncss of a man's 
finger," which bizzed and fluttered away among the dead leaves like a startled Spurfowl. I shouted for my net, but my trusty henchman was out of hearing. "So he too wants breath," I thought, and was pleased.

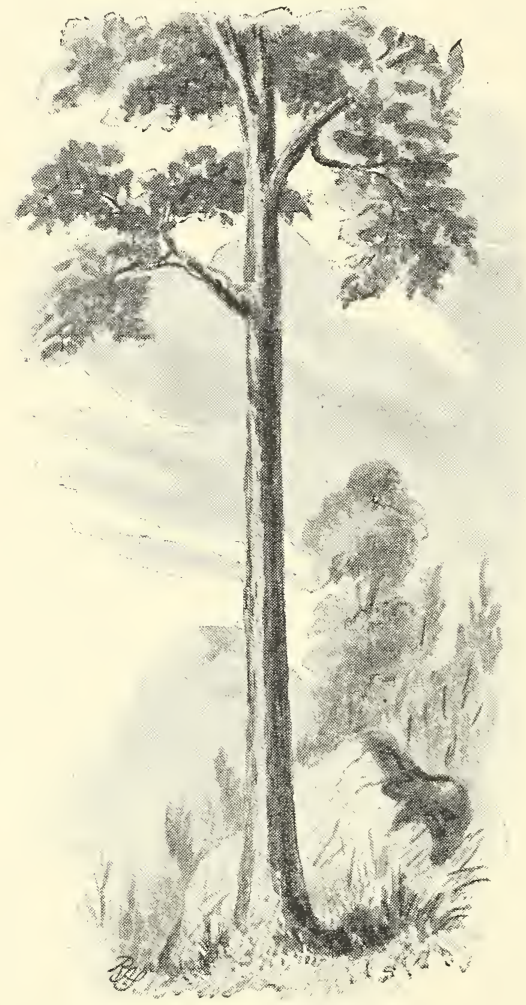

POON TREE.

Relief came now as the path wound round the hill and even dipped a little to cross a babbling stream overhung by a wicked tangle of rattan palm. In the whole vegetable kingdom there is nothing more utterly vicious than this cane. Every joint is set with spines, every frond fringed with recurved thorns, and, as if this were not enough, it holds out long coachwhips, green and supple, 
armed at every inch with fish-hooks to hook the passer by. Why were thorns created, or how were they developed? What is their use, their purpose, or the end of their being? But I will keep that question for another day.

Once again we were climbing a hill, and this was worse than the other. We were forced at last to call a halt and sit down for ten minutes. Then we set forward again. For a moment we stopped to admire a magnificent poon tree, whose trunk, at least nine feet in circumference, rose up before us like Satan's spear. And in truth this grand tree has furnished the mast of many a "great ammiral." A single poon is said to have fetched over Rs. I,00o.

At last we reached the top of the hill and walked on level ground once more. Of course there were still a few supplementary ascents to make, and it was some time before we reached the traces of artificial stone steps which marked the final stage. At the top of this we emerged from the forest and stood under a great perpendicular wall of rock, washed clean by the monsoon rain. A portion of this rock near the top was yellow and friable, and huge boulders lying about us, with fresh edges, gave evidence of a very recent fall, while a gaping fissure plainly foretold another. 
We now laid aside all encumbrances, including our hats, for the cold wind blew like a hurricane, and it was easy to see that any irreverent head reared above that rock would be uncapped in the twinkling of an eye. Even the dark patel removed his headcloth, revealing a long, pineappleshaped head, with a thin cascade of grisly hair falling from the summit. Then we all applied ourselves to the rickety scaling ladders which had been put up for us, and in a few seconds we were on the uttermost peak, beside the dirty rag tied to a bamboo which is the ensign of Basweshwar. How the wind blew! And there, not many yards away, motionless in the air like Mahommed's coffin, was a huge vulture, his enormous wings so cunningly trimmed to the gale that it just held him where he was. Would I were a vulture, only I never could abide high game.

I asked one of the men where the gods were, for in these parts they always speak of a deity in the plural, on very much the same principle, I suppose, on which the Gadarene maniac replied that his name was Legion. The man I questioned smiled and pointed out a small hole or niche in the side of the rock, towards which he scrambled like a lizard. I had no suckers on my fingers or toes, but I found it was possible to get into such a position that my 
head hung over the hole, and then my eyes rested on Basweshwar. He consisted of a small collection of animals out of a Noah's ark, very ill made and out of repair. Some of them were of stone and some of tin or lead. There was a small stone bull, old and much worn, a smaller bull of better construction, a tin horseman on wheels with a drawn sword in his hand, a young hippopotamus, or donkey without a tail, and one or two other little beasts.

There was also a small silver plate engraved with the pug; or footprint, of Baswa, the saint or politician who founded the Lingayet sect, and another bearing a rude figure of a bull. We took these things out one by one and grew funny over them. Yet these are the holy things to do reverence to which hundreds of weary worshippers travel long distances and make this toilsome ascent, spending the whole night on the hill and burning sacred fires. Men laugh where angels weep. Charity cannot veil the truth, nor sophistry change it, that the worshippers of these things are looking downwards, not upwards; and man goes as his face is turned.

My friend, who has the makings of an antiquarian in him, longed to purloin the engraving of a bull, but I 
restrained him, for eyes were on us. We did, however, annex two coins, evidently pious offerings, from a shelf in the rock, leaving in their place a two-anna piece, that we might be able to repel the charge of meanness. When we got the verdigris off these coins, we found that they did not belong to the time of the Sonda kings, but were copper pice of the Honourable East India Company.

In another part of the rock there was a hole, or cave, suitable to be the entrance to a subterranean passage leading to some famous Lingayet shrine in the Himalayas. These holes always lead somewhere. But the men with us were not Lingayets and would not even invent information. However, the patel supplied the want by giving us an account of the rise of the shrine. He showed us a well in the rock which never gets dry, and the broken walls of a temple and fort. These were never completed because of the mortality caused by tigers, which carried off four or five of the workmen every night till they abandoned the work. The instruments of worship are now kept in the valley below and brought up for the annual festival.

We believed all the patel told us, and put it down in an M,P.'s notc-book which we keep. Then we returned 
as we came, putting on the brake where we had got up steam. Treacherous roots made loops across the path to catch our feet, but we escaped disaster and reached our camp at I o'clock. The men who went with us are no doubt looking to hear of our sudden death from cholera or snake-bite for having provoked the anger of Basweshwar. They are not Lingayets, but that makes no difference. In this country a man believes in all gods and worships his own, just as he believes in the Queen of England and the Czar of Russia, but offers his limes to the Collector of the district.

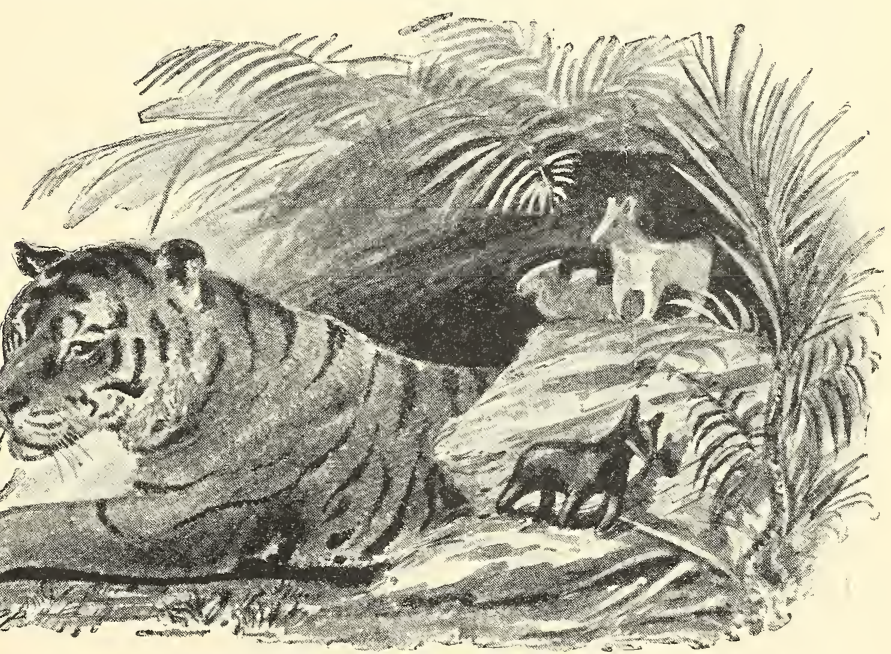

THE GUARDIAN OF THE SHRINE. 


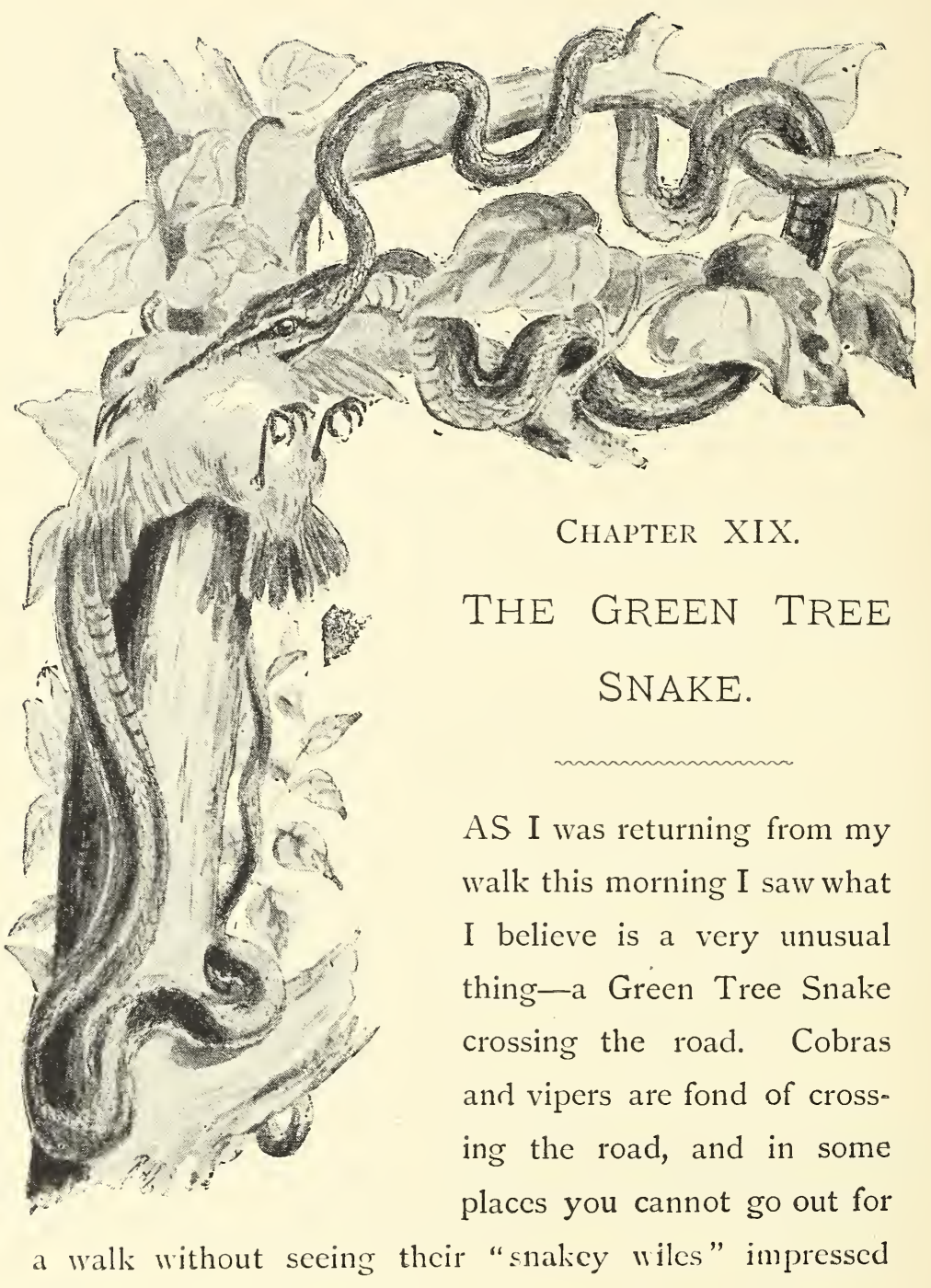


upon the dust. A good man once assured me that they do this on purpose to eat the dust, and so fulfill Genesis iii. I4. But the Green Snake appears to be exempted from the curse, and you oftenest find it festooning the slender branches of some tree, or gliding over the twigs with a swift, imperceptible motion, like a clear stream over a mossy rock. This one was crossing the road, however, beyond a doubt, when I came upon it, and I was puzzled to know what its object could be. Of course I know that it was crossing the road because it wanted to get to the other side. That occurred to me at the time. But I mean, why did it want to get to the other side?

On the other side, among the grass, was a very large black snake-a cobra, I think-and if the Green Snake had accomplished its purpose, its next course would have been, I fear, down the black snake's throat. But at the sound of my footsteps the black snake rustled away, and the Green Snake gently raised its head and began darting out its long, forked tongue.

Why do snakes dart out their tongues in that foolish way? Nobody knows, and I cannot even begin to guess until I have got an answer to another riddle, more difficult 
still. Why do snakes have those foolish tongues at all? I cannot think of any purpose which the absurd instrument can serve. As a symbol it is perfect. If I were a painter and my subject the Old Serpent, who is the father of lies, whispering into the yet innocent ear of the mother of all living, just such an oily, double tongue would I give him. But the Green Snake was not created to be a symbol. All modern science is opposed to such an idea. Let its tongue pass for the present.

There it lay, a beautiful creature, as green as grass, nearly three feet long and shaped like the thong of a lady's hunting crop. Its head was very long and narrow, with a peculiarly sharp snout, and its eye large and bright, with a cross bar for a pupil. What does it feed on? Its throat is scarcely thicker than a goosequill just now, but what it can stretch to I dare not say. I have lately seen a photograph of a python coiled round a large Blackfaced Monkey. The monkey was in articulo mortis, his countenance passing from pain into the placid sadness of death, and the python was wound about him, with its grim head resting coldly on his shoulder. The picture was not a fancy one. The python was found in that position, not very far from where I now am. 
Now the neck of that python was not thicker than my wrist, but I am quite sure that it would not have been at the trouble to squeeze the life out of that monkey if it had not trusted it could swallow him. So it may be that my Green Tree Snake lives on little birds. I hope not. It certainly did not appear to have a guilty conscience as it lay there, with its head a little raised, looking strangely at me. I touched it with my stick, and it lifted its head a little higher. Then I put my stick under it gently and lifted it up. If it had been dead it would have slid off on one side or other, but being alive, it perched on the smooth stick as if its scales had been so many little grasping feet. Its tail hung down one side, and on the other its neck rose up in a beautiful curve, like the letter $\mathrm{S}$. It seemed rather surprised that a branch of a tree should have come down to it and saved it the trouble of climbing. It concluded that I in my green shikar suit was the tree, and began to advance along the stick with the view of climbing up my arm and mounting my hat. Then it changed its mind. It seemed to think I was not an inviting sort of tree, not leafy or twiggy enough, only an old mossgrown trunk. I really wonder what was passing through the strange creature's brain! 
But, by the way, I do not think it has a brain, not having, in truth, any proper place to keep one. Such brain matter as it requires to get through life with is spun out into a sort of chord, threading the beads of its supple spine. This is why a snake seems to think and act all over its length. Long after you have silenced the head the tail goes on protesting. It is the boasted principle of local self-government: there is nothing new under the sun.

However, there must be some pretence of a central directing authority in the polity of this snake, for it can apparently form a purpose and take measures to carry it out. I see that it has decided to drop off my stick into the grass. By degrees it lets itself down till its head is near the ground, while its tapering tail is wound firmly round the stick. Then the weakness of all such systems comes out. The tail refuses to obey orders and will not let go. Then the head comes back to see what is the matter, climbing up its own neck with easy grace. But when it has got half-way up, it reconsiders the matter and allows that the tail has a right to its own opinion. Then general vacillation sets in. Every part begins to act for itself with wonderful energy, producing the most beautiful 
effects, curves and twists and graceful swaying motions, all tending nowhere.

Meanwhile I, who am not troubled with local selfgovernment, was making substantial progress homewards, I passed several carts, the cartmen looking out from under their blankets with drowsy wonder. They never knew before that Sahebs practised snake-charming. When I had found a nice grassy plot, I lowered my stick, and the snake slid away, wondering where all the agitation of the last half hour had landed it.

No animal has been used by Europeans in India to graft so many superstitions upon as the Green Tree Snake. It is the "Whip Snake" of commerce, the Corralillo of Madame Blavatsky. No matter whether it bites you with its mouth or whips you with its tail, your doom is sealed. It hangs from the branches of a tree on the wayside, watching for some unsuspecting passenger's uplifted eye, that it may drop into it. You may have observed that no M.P. travelling through India ever uplifts the eye, except metaphorically. He has been warned. Now I would not willingly deprive even an M.P. or a Theosophist of any of the romance of travel, but we owe a duty to all our fellow-crcatures, and I feel bound 
to testify that I have found this poor Green Snake to be the most harmless and the gentlest of living creatures. And its tameness is charming. It seems to have no fear. This is because it is green.

If you meet a black snake it flees for its life, and if you meet a viper, it hisses and dares you to touch it. Were the Green Snake to do either of these things you would kill it, but because it is green it just does nothing, and you brush past the leaves among which it hangs and never know it is there. So one animal is saved by wariness, but another by the want of it, just as one man pushes his way through the world by impudence, and another, like Uriah Heep, by 'umbleness. I meet with fresh instances of the same thing every few days, with moths, leaf insects, stick insects, spiders, dressed in strange disguises, which would inevitably be eaten if they fought or fled, but escape because they do neither. Seeing these things from day to day, one slowly comes to take in the truth that lies in that phrase of Darwin's, "The Struggle for Existence."

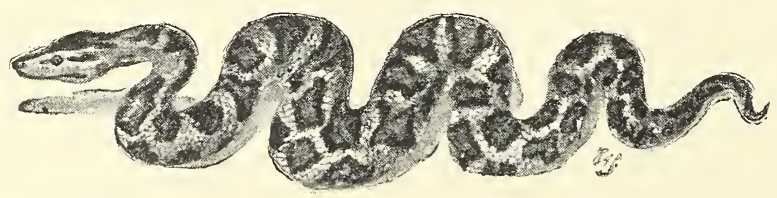


Chapter XX.

\section{AN ANTHROPOID.}

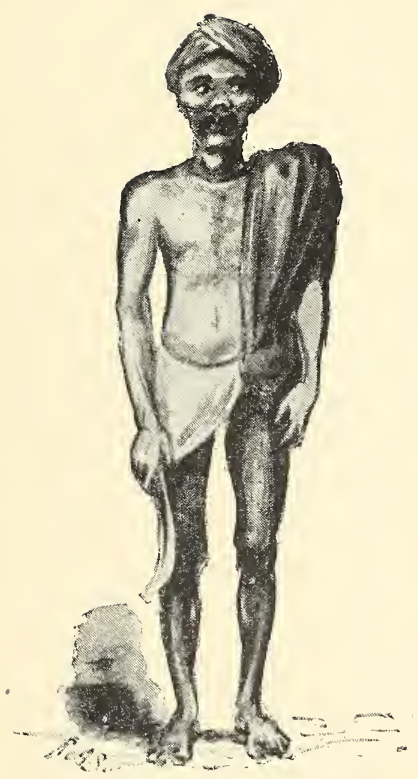

THERE is an anthropoid in habitant of these hills in whom I take an interest. The local varieties of him are many, from the purely feral Katkurree of the Tanna and Kolaba jungles to the half-domesticated Koonbee of the Canara forests, but I do not think they constitute more than one true species. It may easily be recognised from the following description :-

Of small or medium size, colour varying from brown to nearly black, hands and feet prehen-ile, ears perforated, earrings present or absent according to financial condition, body and limbs almost entirely nude, hair on head various, hair on face wanting or noarly so, upper part of body bearing, in winter, a 
deciduous mantle called a kumblee, lumbar region armed with a sharp koita, removable at pleasure, close to which there is a gland or pouch containing a brown substance resembling tobacco; habits terrestrial or arboreal; habitat, the forests of the Sahyadri range.

To this description it may be added that he constructs for himself a hut of various materials, such as branches of trees, bamboos, the stems of the karvee and grass, put together with much ingenuity and plastered with clay. On one side there is a small aperture, which affords exit to the occupants and also to smoke. As ants' nests often contain small bectles, or curious insects allied to cockroaches, for whose presence naturalists have never been able to account satisfactorily, so dogs of an undetermined species, and sometimes cats, are found in the dwelling of this anthropoid, but it is difficult to say what relationship subsists between them and the occupants.

The anthropoid does not decorate his place of shelter with shells and bright stones, like the Bower Bird, but in one corner you will always find a few pots and pans of metal and an earthen chatty or two. Beyond these and a small store of food grains he appears to have absolutely no possessions, for the kumblee and the koita are more like parts of his structure. They are to him what claws are to the tiger, or the trunk to the elephant, and to under- 
stand him at all you must study them as a zoologist studies the teeth of a strange animal.

The kumblee is a home-spun blanket of the wool of black sheep, thick, strong, as rough as a farrier's rasp, and of a colour which cannot get dirty. When the Koonbee comes out of his hole in the morning it is wrapped round his shoulders and reaches to his knees, guarding him from his great enemy, the cold, for the thermometer is down to $60^{\circ}$ Fahrenheit. By-andbye he has a load to carry, so he folds his kumblee into a thick pad and puts it on the top of his head. Anon he feels tired, so he lays down his load, and arrang-

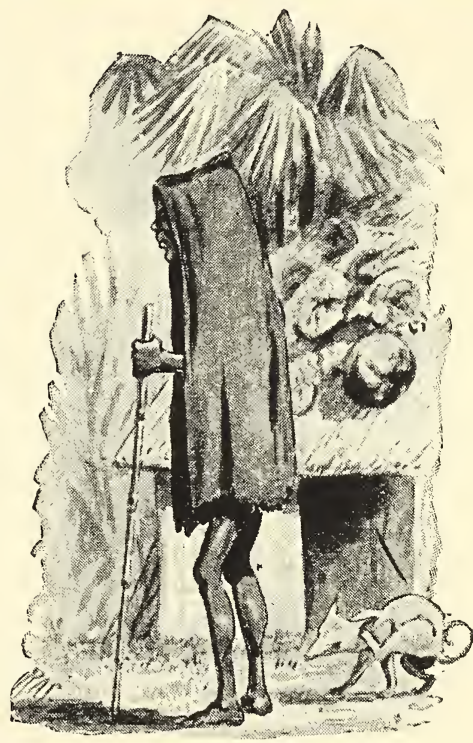

THE ANTHROPOID AT HOME. ing his kumblee as a cushion, sits with comfort on a rugged rock, or a stony bank, and has a smoke. Or else he rolls himself in it from head to foot, like a mummy, and enjoys a sound sleep on the roadside. It begins to 
rain : he folds his kumblee into an ingenious cowl and is safe. Many more are its uses. I cannot number them all. Whatever he may be called upon to carry, be it forest produce, or grain, or household goods, or his infant child, he will make a bundle of it with his kumblee and poise it on his head, or sling it across his back, and trudge away.

And whatever the kumblee cannot do, the koita can. It is an instrument midway between a hatchet and a pocketknife, and consists of a broad, steel blade, curving round

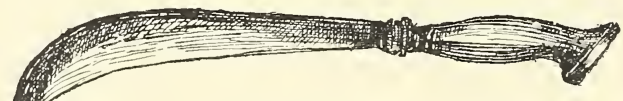

THE KOITA.

to a sharp point, and a short wooden handle, which looks simple, but is more ingeniously contrived for giving a firm, yet easy, grasp than the best tennis-bat that Ayres ever turned out. In the hands of one born to the use of it, there is nothing in the way of hewing, chopping, cleaving, peeling, or paring, that this instrument will not do. To say that the koonbee pares his nails with it is a fable, because he does not pare his nails at all; but it you would know what he can do with it, watch him as he prepares the stony beetle-nut for his quid, or peels sugarcane and 
chops it into lengths, or slashes the thick rind from a green cocoanut, and then chips a small hole in the shell that you may quaff the refreshing beverage with which it is filled.

When at rest the koita hangs from a curious contrivance attached to the Koonbee's waistband behind, in which position the broad, keen blade hangs over and partly curves round his undefended sitting parts, and it has always been a mystery to me how it is prevented from taking "sections" at every step. But it is rarely at rest. Whenever a thornbush, or tangled creeper, or errant branch of a tree, obstructs his course, his weapon flashes out and the Koonbee walks on, leaving a broad path behind him flanked with vegetable ruin. How often has he pioneered me through what, without his koita, would have been an impenetrable thicket. It is a fine sight, but after all it is only like watching a tiger devouring his allowance of flesh behind his bars at the Zoo.

Could you watch the Koonbee as he wanders alone through his native wilds, it would be like following the same savage beast when it leaves its lair and goes forth in search of its prey. In mere wantonness you would see him lop the branch of a fair tree and leave it to wither across the path, or with a single slash kill the young 
sapling that would have grown into one of the monarchs of the forest. In a few minutes, and to satisfy the needs of an hour, you would see him reduce to perennial unsightliness the shapeliest works of Nature's hand.

You will infer that the Forest Department regards him with no friendly eye, and you will be right; for, in sooth, there is bitter enmity between them. The zealous officers of that Department regard the Koonbee, I am told, as vermin, which ought to be destroyed, and he, I fear, regards them as gamekeepers, whose mission is only his destruction. And now at last they have devised a means to exterminate him by putting an end to a practice which he calls koomree." This is a method of agriculture which he prefers to all others. It consists in felling the forest, burning it where it lies, scattering a few handfuls of coarse grain among the ashes, and reaping the crop when it is ready. Thus, by destroying forest worth a hundred rupees, he gets a crop worth twenty for a year or two, and then the strength of the virgin soil is exhausted, so he moves on and repeats the process elsewhere.

From time immemorial he has lived by tilling the r.ound in this simple fashion without check, and now it 
is forbidden, and nothing remains for him but to die. I feel for him, but I should like to feel for him wisely. The echo of all suffering, deserved or undeserved, should be sympathy, but sympathy, like some precious balm, may be applied to the wrong part, unless you clearly understand the disease. So I tried to diagnose the case of the poor Koonbee. I selected a dirty, little old man, whose mother had named him Yelleep and bequeathed him a pleasantly ugly face, with a genial smile, which quite lighted up the few reddish yellow teeth that still remained in his old mouth. I thought I might gain his heart if I translated to him the words of the poet-

"Drops of compassion

Tremble on my eyelids,

Ready to fall as

Soon as you have told your

Pitiful story."

But I found that my acquaintance with the noises which he called his mother tongue was not equal to the task. So I put him a simple question, What did he eat? He replied that he ate nothing! How could he eat, having no food? Further questions only served as encores to cvoke a repetition of the same song. It was evident that, though his brain was like a London sky, one idea loomed 
distinctly through the fog, and it was this, that he was a miserable creature and good might come of my knowing it. However, I took him in flank and rear, and laid snareful questions in his path, until I had got a tolerable idea of the resources of his little community. They cultivate rice in the monsoon, and some fields produce a second crop in the cold season. They can grow sugarcane too, and coffee is almost wild. They collect myrabolams in the jungle, for which the Forest Department pays them at a fair rate. They have no lack of cattle, but the cows yield little milk, and what they yield the Koonbee does not use. He keeps no poultry, because it is against the rules of his caste to eat fowls or their eggs; but he doubts whether the jungle fowl is a true fowl, and he gives himself the benefit of the doubt, snaring it when he can. $\mathrm{He}$ sets most ingenious traps also for wild cats, against the eating of which there is no law, and nooses for hares, which, though not so tasty as wild cats, are not to be despised. Sometimes (my authority is Yelleep) the wild dogs kill a Sambhur near the village, and he robs them of their prey and dines on venison. Of fruits he has the Plantain and the wild Mango, and, above all, the nutritious and delicate Jackfruit in unlimited quantity. Of wood for 
building his hut, or cooking his food, or warming his body, he has a hundredfold as much as he can use at his very doors.

I said to myself, What can be the matter with this man? His wants are as few as the wants of man can be, and his resources are many and almost boundless. Why is it that he does not prosper? In the midst of pastures so rich that herds of very fine cattle are brought here from other districts to graze, why should his cows yield no milk? With fields watered by running streams and a fertile soil, why sheuld his crops be always like the seven bad ears in Pharaoh's dream? With the riches of nature so bountifully scattered about him, why should he be always poor? What has been his bane? Something suggested, koomree. To say that he has lived from time immemorial by koomree, what is it but to say that he has lived from time immemorial with no necessity for strenuous toil, or wise forethought, or anxious care? And the natural result is this poor creature Yelleep. If this be so, then his posterity may bless the day when a kind Government cut short the practice which he so cherishes, as the surgeon amputates a mortifying limb.

I did not address this argument to old Yelleep, because 
he could not have felt the force of it. He is not interested in posterity. What has posterity done for him? His interest circles round the passing hour in his own little life. So I let my sympathy touch him where he could feel it. Bidding him get me a bit of sugarcane for my horse, I gave him a silver two-anna piece. His eye glistened, and he asked when I would visit his village again.

Yes, the lot of old Yelleep calls for manifold sympathies. Though his appearance does not suggest it, he also, like Carlyle's "infinite Shoe-black," "has a soul quite other than his stomach." "Half of a Universe," or "Oceans of Hochheimer" will not satisfy him. Indeed, he would refuse your Hochheimer, for he is a total abstainer, even from the harmless juice of his jungle palm; and this, I take it, is an unconscious admission that his soul is more than his stomach.

If you explore the country round about his haunts, you will find weird evidences that that soul of his disquiets him at times. Under a dark and gloomy tree, where Satyrine butterflies dance, you will find images in clay of horsemen and cattle, or strange figures carved on stone pillars, to which he makes solemn approach at times with 
ceremonies as strange, and offerings propitiatory or expiatory. Do not ask him why he does so, for he knows not. When the jungle tick bites him, he scratches himself, and when vague pains or fears from within disquiet him, he makes oblations. Scratching makes the bite worse, and I fear his oblations make his soul no better, but he goes on with the one as with the other, poor, "darkly sinning, darkly suffering" Koonbee.

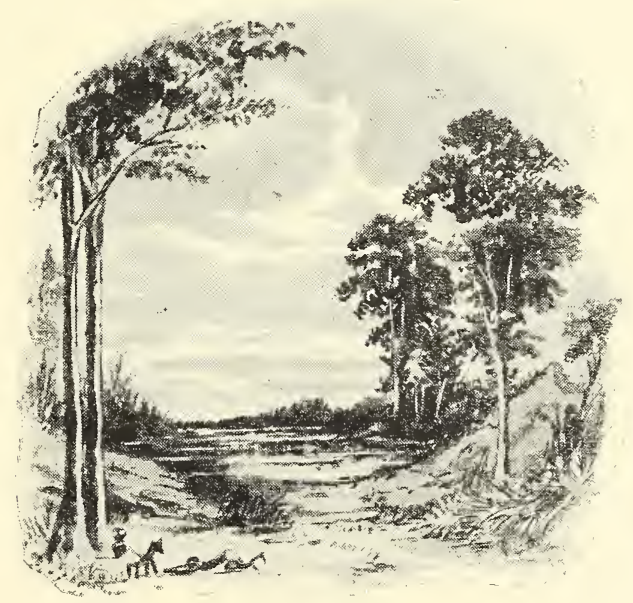




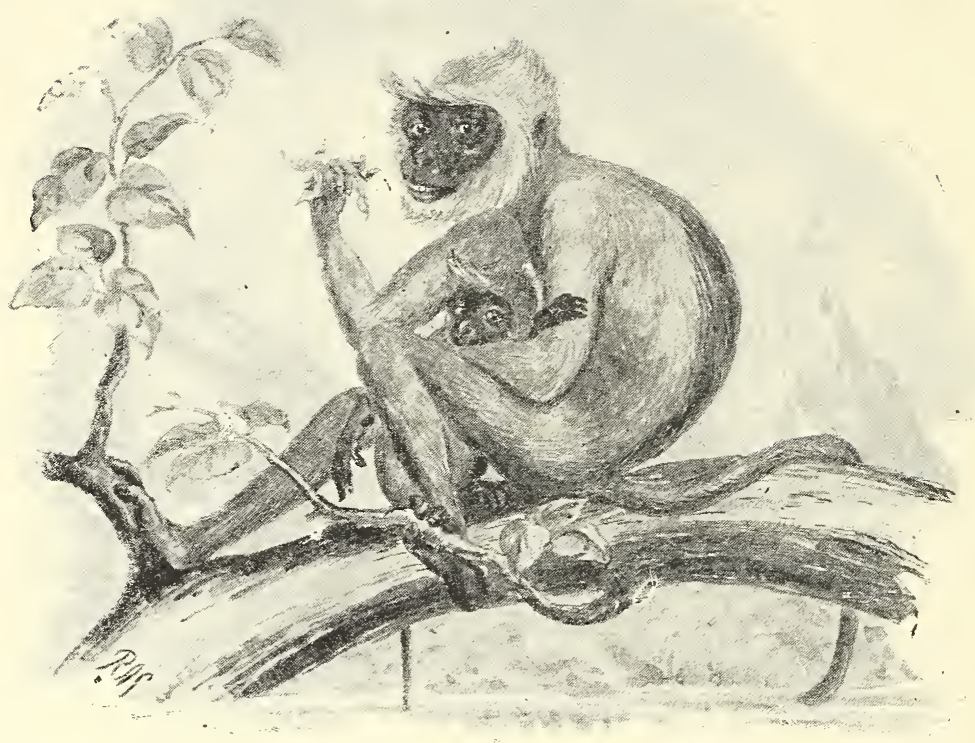

Chapter XXI.

M O N KE Y S.

IT was cruelly cold this morning in my extempore hut of green leaves, which did nothing to keep out the wind and little to keep out the dew that gathered and fell, like the first drops of a thunder shower, from the branches of the trees ovcrhcad. Glad I was, when I crawled out of bed, 
to sce that the embers of last night's $\log$ firc were still smouldering outside. So I stirred them into a warm glow, and putting a camp chair and a miniature table beside them, enjoyed the luxury of hot coffee as I have rarely done. Surely there is a way of taking even animal pleasures that does not debase. I loathe an epicure, but I would not be a stoic either. It has always seemed to me that the breadth of mind of the great Apostle of the Gentiles nowhere shows itself more strikingly than when he says that he is instructed both to be full and to be hungry. Even in little things I should like to learn the same lesson. So I think it no shame to dwell on the recollection of that pleasant cup of coffee beside the warm fire and under the green trees, before as yet the sun had shown himself over the high hills to the east. In strange contrast to my cosy arrangements, but with evident zest too, a troop of monkeys were having their chotee hazree on the trees all round; so I got out my binoculars to have a good look at them. I was not in a speculative mood. Speculation, the effort to reach from the known to the unknown, is an exercise without which some minds cannot grow. They are like some climbing plants, which throw out long, blind arms into the air, groping for something of 
which they may lay hold and so mount higher. But this habit of speculation easily becomes a disease, so I will not speculate this morning, but only observe.

The monkeys are scarcely thirty yards away, and the glasses bring them so near to me that I feel as if I could pat their heads. One fine old patriarch is sitting on a Jackfruit tree. Monkeys do not perch, nor squat like natives, but sit as a man does on a low stool. They are very clever at finding seats among the branches with a rest for their feet in front, and the long tail hanging down behind seems to make their position more secure. I imagine tails werc discarded by degrees as the advanced apes took more and more to the ground. But I am speculating again and on a dangerous subject. The patriarch on the jack-fruit tree sits with his back curved like a large C. He needs a little discipline with the back board. From time to time he examines the ends of the branches, and nipping off a tender shoot, puts it into his mouth and munches away. There is a weary look in his light brown eyes. Why do monkeys always look so sad? The hair of his head projects over his low forehead like the peak of a cap, and his coal-black face is fringed with a hoary line of whisker and beard, which follows his jawbone like the first growth on the face of a 
young Jew. The beard of the Lion Monkey is like that which will dignify the young Jew ten years later. I see a fine avenue for speculation here, but I will refrain. There are no Lion Monkeys quite so far north as this. These are all Langoors, or Black-faces. On a Mango tree hard by there is another, which is a mother and has a little son. I cannot guess his age, but his stature, when sitting, appears to be seven or eight inches. He feels the cold, and follows his mother about till she sits down, and then he comes and nestles in her bosom. She goes on nipping off tender shoots and eating them.

The scene takes my thoughts back a year or two, to one of the most pathetic sights I ever saw. One morning, on a rocky hill sparsely covered with small trees, I disturbed a troop of monkeys, which made a bolt over the open ground to some thicker forest in a valley below. Three however, disregarding me, remained in one tree, making horrible noises at something underneath. I soon discovered that the object of their indignation was a brutal-looking black dog, which was busily devouring something at the root of the tree. When the dog saw me it made off, carrying in its mouth a black thing, like a little animal, with legs and a long tail. I guessed it was a baby monkey 
and gave chase as hard as I could, but the dog made good its escape without dropping its prey. Coming back to the tree, I searched the ground and found the body of another little infant, still warm. How did the poor little thing fall into the jaws of that brute? I have often seen an infant of the same size clinging to its mother's breast in perfect security while she took the most daring bounds from tree to tree. Perhaps the dog surprised the monkeys on the open ground, and pressed the mother so hard that she dropped her offspring to save her own life. Or perhaps they were enjoying a picnic in fancied security, and had laid down their little ones when the Zulu rushed upon them. While I was examining the limp little body, to see whether life was extinct, a pitiful wail told me that its mother was watching me. She had retired to another tree some distance off, and was wistfully gazing at me, wondering what I was doing with her precious babe. I saw that there was no hope, but I retired and hid myself to see what she would do. She came down at once and approached cautiously, distrusting me and lumping me in her mind, no doubt, with the brutal black dog. Then she got upon a stone, and standing erect, looked all round and grave a plaintive scream. Where was her darling? At last she 
saw it and ran to it and caught it up and pressed it to her bosom. But it could not lay hold of her; it fell. Again and again she raised it and encouraged it to clasp her in its arms, as it had always done. She did not seem to understand that it was dead. At length she held it to her bosom with one hand, and tried to run on three, lest the black dog might return. When she got to a safe tree, she clambered up as best she could, hugging her precious charge with one arm, and there she gave way to her grief and cried piteously, while a kite sailed grimly round the tree, as if claiming his

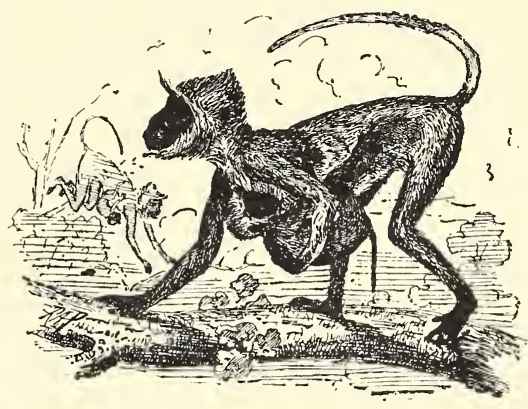

LUNGOOR.

own. I have often wondered what she did in the end with the little lifeless body. I cannot believe she left it to the kite. It would not surprise me to know that she buried it, or laid it in some hollow and covered it with leaves and stones.

As I watched the old mother in the Mango tree, picking and eating the juicy shoots, with her child in her lap, my ear caught the sound of a woodpecker hammering with unusual energy. It was not the quick, fierce rap 
with which the bird startles the insects from the bark of an old tree, but the slower and heavier stroke with which it excavates a hole for its nest; so I got up to reconnoitre, and what was my delight to find that the sound proceeded from a pair of those curious birds, the Red Woodpeckers (Micropternus gularis), working together at an ants' nest, one of those great brown globular structures which disfigure the branches of the trees on all these hills. The inmates were pouring forth in hundreds, fuming with rage and holding their absurd tails over their heads, but the birds did not appear to mind them. They worked away for a quarter of an hour, then left, and have not returned. But they will return and finish their work and bring up their callow young in the penetralia of the habitation of a horde of the most venomous and implacable little insects that the world produces.

As I was watching the woodpeckers, Banawat Beg came to inform me that a Bullock Dove was sitting on the top of a Jack-fruit tree. Turtur meena is the Bullock Dove, because it is always found about those open camping grounds at which the weary troops of grain-laden bullocks close their music and lay down their burdens for the night. The Bullock Dove is fat and tasty, and I, moorgee fed 
mortal, shot this one and handed it to Pedro to be converted into "second course."

And so the quiet current of peaceful observation is broken. It is common to associate sport and natural history, and their conditions and surroundings are often the same, but their spirits are contrary. Murder, which is the sportsman's aim,

"Jars against Nature's chime, and with harsh din Breaks the fair music that all creatures make To their great Lord."

And to have our ear tuned to hear everywhere that music is the greatest pleasure and the highest good which the pursuit of natural history offers to us.

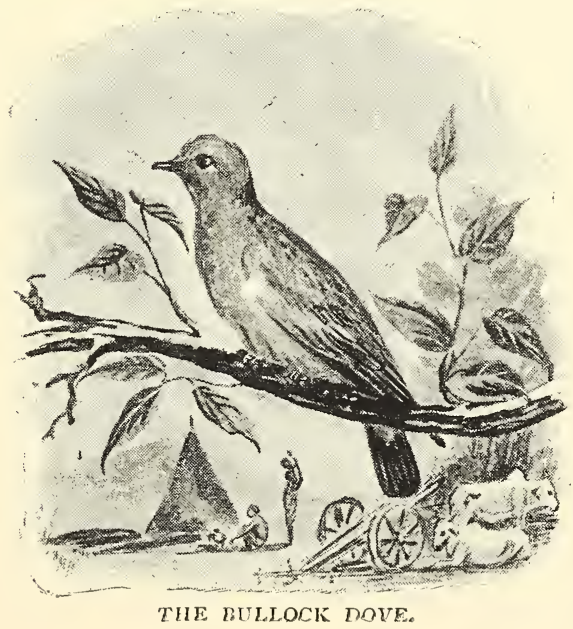




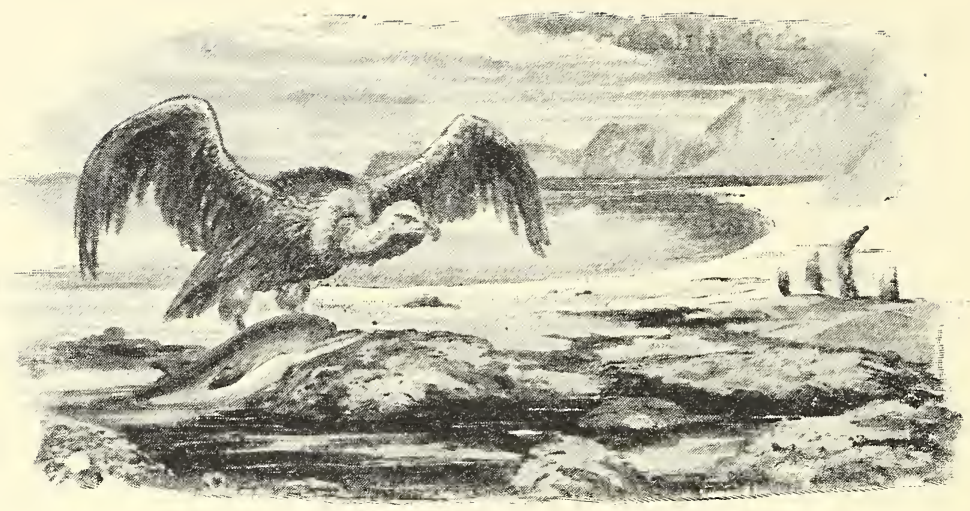

Chapter XXII.

\section{ANOTHER WORLD.}

$\mathrm{ON}$ the white sand of the sea-shore, against a background of hazy blue, dark, erect, statuesque, with wings outstretched, stood a gigantic vulture. In the heraldry of nature this means that there has been a funeral among the village dogs. At least, this is how I interpreted it, and I looked eagerly round, with handkerchief to nose, for the disjointed bones and ragged leather of the foul brute whose ululations were never to trouble me again. But the beautiful beach was clean and white. There was not 
so much as the body of a bandicoot to defile it. Then I looked towards a little shallow pond, an inlet of sea water, filled at high tides, near where the vulture stood, and noticed that a large, black object was floating in it. When I turned my steps to see what it was, the vulture began to walk, first slowly, then faster and faster, like an old lady trying to catch an omnibus. Then it broke into a trot, and from that into a gallop, while its great wings beat the air, until it was lifted off the ground and sailed away over the cocoanut groves and the blue hills beyond.

And what do you think had brought it there? It had come to "prospect" the corpse of a porpoise. It had evidently found the concern unworkable, and resigned it to me without a grudge. I found it unworkable too, for it must have been dead some two or three days. Its sides had shrunk in, the merry little eyes were gone, and the long row of sharp teeth showed fiercely in the shrivelled snout. Alas, poor Yorick! Perhaps I had seen him before and watched his sportive gambols round my boat. $\mathrm{He}$ would come up with a puff and heave himself half out of the water and dive again, waving an adieu with his tail to the inhabitants of the world of air. He had doubtless been a prince of his tribe, for he was a large porpoise, 
measuring fully eight feet and a half in length. Now he will gambol no more, and the herd will follow another leader. But perhaps he did not gambol. Perhaps he was a solitary and surly old brute. I always think of porpoises as the merriest of beasts, but it may be a very one-sided view. We only see them in their sportive moods and fancy they are always sportive. When they are sullen or sad, doubtless they mope somewhere down in the dark unfathomed caves of ocean, looking at the gems of purest ray serene. And if they have fits of ill-temper or fierce passion, in which they become as dangerous as a rogue elephant or a mad bull, how should we know ?

These things go on in a world to which we have no access. I wish that I could gain admittance to it for a while and watch the ways of those who are born and live and die within its bounds. I should like to see a mother porpoise with her young. Where does she cradle it, and how does she nurse it? Remember, that the baby porpoise is not a fish, but a beast, and would soon die if left at the bottom of the sea. The mother must not only feed it and warm it, but "breathe" it. Does she clasp it in her flappers and bring it up and hold its little nose above the water? Her lot is happy in one thing: her baby cannot 
cry. What a mercy it would be if we could put human infants under water, not always, but just sometimes, when they wax too- - But I am writing like a słameful old bachelor. Let us return to our mother porpoise.

Has she a cosy bed of seaweeds down in some hollow of the deep, where sharks will not find it? Is she terrible at such times with those grim teeth of hers? Whalers say that maternal affection is very strong in all these warmblooded denizens of the sea. Moving among cold fishes and eels and brainless cuttlefish and jellies, they nurse their young and love them and show that they belong to a higher order of beings.

Thinking of these things, one comes to realize that that blue surface, rippling with silvery waves, separates two worlds. We sail over it and are conscious of one world only, the beautiful world of sunshine and green hills : the blue waves seem to be a part of it. But down beneath the blue waves are there not hills too and valleys, smooth slopes waving with soft sea-weed, coral-capped mountains on which the sunbeams play through the restless water in hyaline tints, dark ravines which no ray ever reaches, black precipices, oozy flats? No winds are there, but currents blow. There is no landscape, no distant view, 
but changeful tints of mellow light : no sound, but a kind of murmurous silence more or less distinct.

To this weird world fishes belong by birthright, and in it they seem to be in their proper place; but how did airbreathing beasts become natives there? How came the Red Indian to the New World, where Columbus found him? There be many questions, but few answers. Otters invade the world of water, and spend much of their lives in it, but they come home to a warm burrow and a dry bed. The seal, too, and the walrus hunt for their prey in the deep, but their birthplace is on the ice-covered shore, and there they return to rest. With the porpoise and the dolphin and the grampus and the whale the case is different. They have cut off all correspondence with their blood relations on the land. Their fore-feet are fins, only two bones remain to witness that they have a hereditary right to hind legs, and their tails are modelled after the tails of fishes. There is one bond they cannot break, however. They must breathe our air or die. So they come to the surface of the water, to the borders of our world, and lift their heads, and we see them. And how do we welcome them? With harpoons.

The fishermen of these coasts set little value on the 
oil of the porpoise and none on its hide, and for this I feel grateful. Sometimes the porpoise gets into the great stake nets and is hauled up with other big "fishes," to be cut up and eaten; but for the most part he is not persecuted, and will frolic without fear in the very harbour among moving boats. This is Steno plumbeus. Doubtless there are other kinds, but a glimpse of a nose, then of a back, then of a tail, is a scanty foundation for an intimate acquaintance. Whales are not uncommon, and will now and then collide with a fishing boat, or small pattimar, and send it to the bottom.

The best view I ever had of a whale was not far from here, when two dark islands appeared to rise up suddenly not far from the boat in which I was sailing. They were doubtless Balaenoptera indica, the largest of all living things in this world. They swam peacefully, side by side, diving for a few seconds and then rising again. At last they went down into their own home and left me, as comets from unknown regions of the universe show themselves, and when we liave wondered at them for a while, depart again.

On the evening of the day on which I saw the dead porpoise I fell in with an old fisherman, who told me all abcut it. He had becn the first to see it two days 
before, drifting in with the tide. It was then quite fresh, and if he had only been a Kharvee, or a Hurkuntur, or a Diwar, there would have been a feast that night, for he told me in a tone of sweet resignation that porpoise flesh was very good. But he was a Gabit, and Gabits do not eat porpoises. I asked why not, and he said that it was not the custom of his caste. And this was sufficient.

After all, in a world of mystery, surrouncled by a hundred things he does not understand, what safer course can a man take than to do as his fathers did? So rain runs in the channels cut by the rain that fell before it and finds its way to the sea. You will say that no progress is possible if we follow this doctrine. But progress is not one of the gods of the Gabit, and he will not worship it. Who knows where it might lead him? He desires safety and deliverance from the hazard and travail of thought. If you press him to tell his reason for not eating the porpoise, he will say, with a diffident grin, that his people consider it a cow of the sea. But this is philosophy, or theology if you will. Man, being a rational animal, must frame explanations of the things he does, or refuses to do, but these explanations come after his actions and have nothing to do with the motives of them. The reason why 
the Gabit will not eat porpoise is that he is a Gabit and no Gabit eats porpoise. And it is the same with us all. Why do we Englishmen not eat frogs? Because it is contrary to our caste. Frenchmen eat frogs. At one time the porpoise was eaten in England and graced royal banquets. It was served up with a sauce of bread crumbs and vinegar and sugar. But caste rules change even in India. What did Hindoos not eat and drink in Vedic times? So now we do not eat porpoise and look down on those who do-like the Gabit. After all, there is a great deal of human nature in man, whatever his colour or creed.

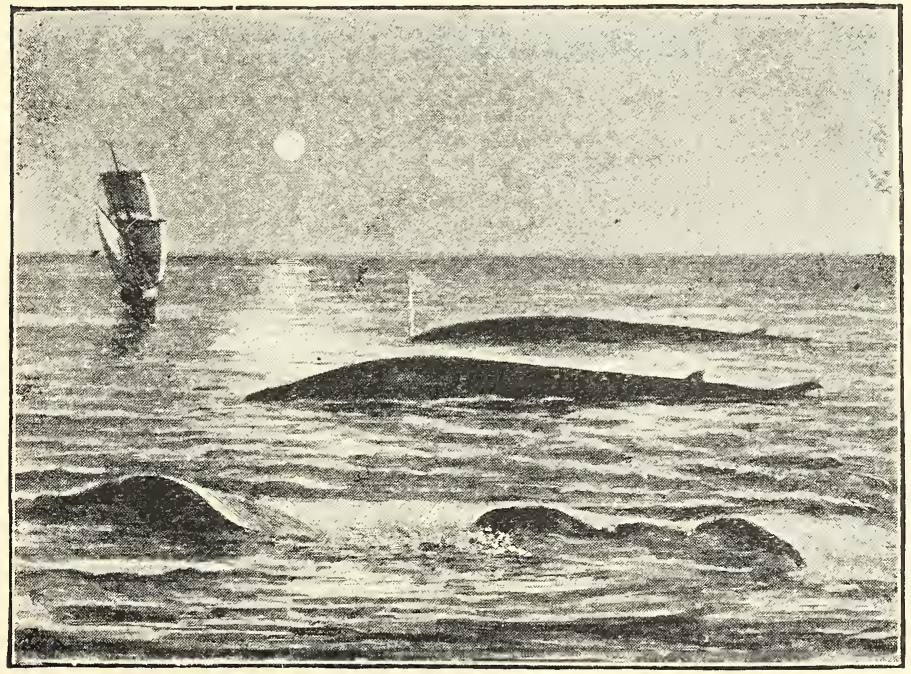


A.

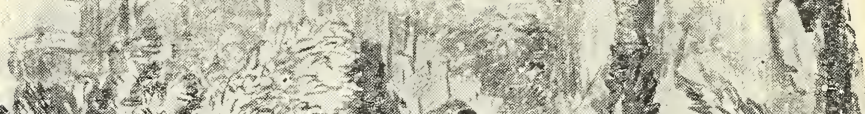

1)

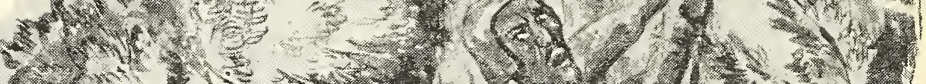
(2)

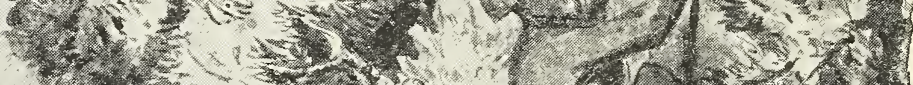

(1)

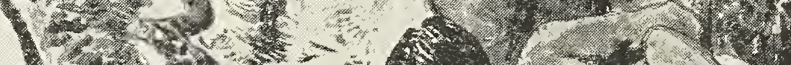

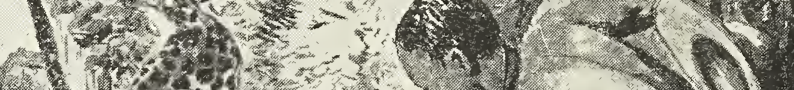

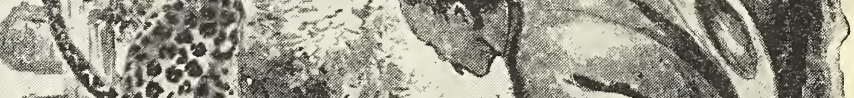

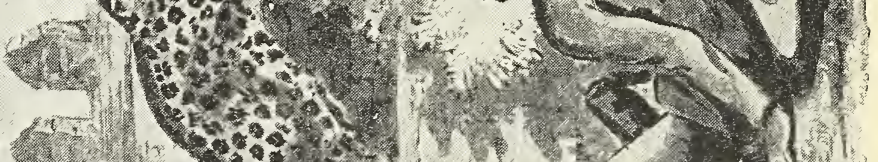

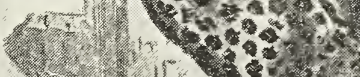

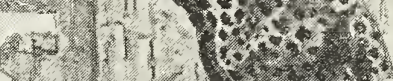

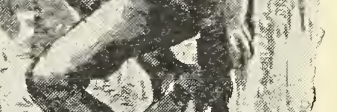

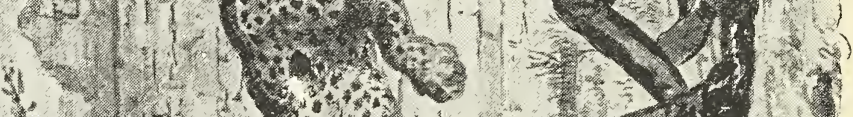

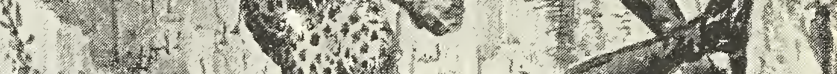
20. -

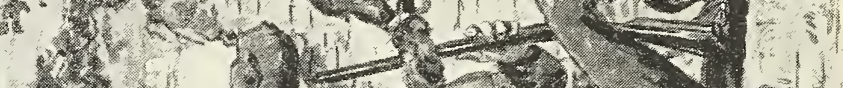

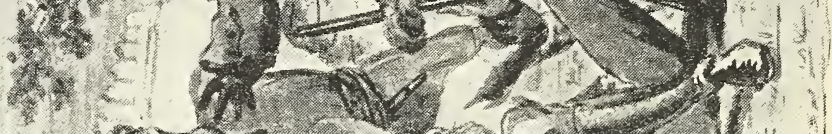

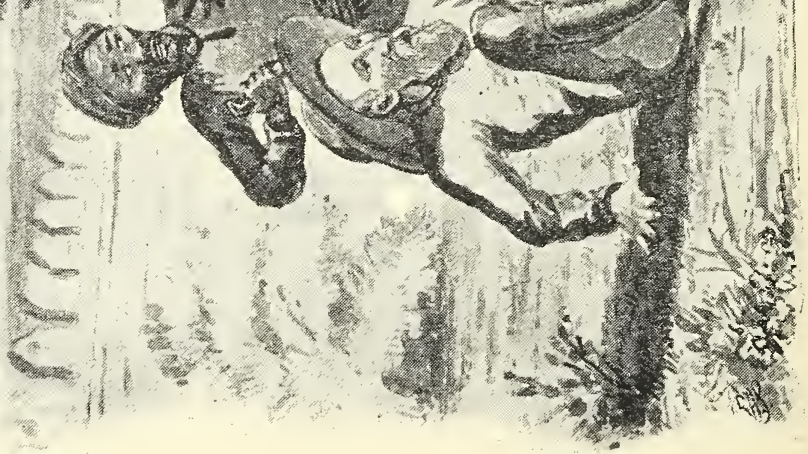




\section{Chapter XXIII.}

\section{A Panther Hunt.}

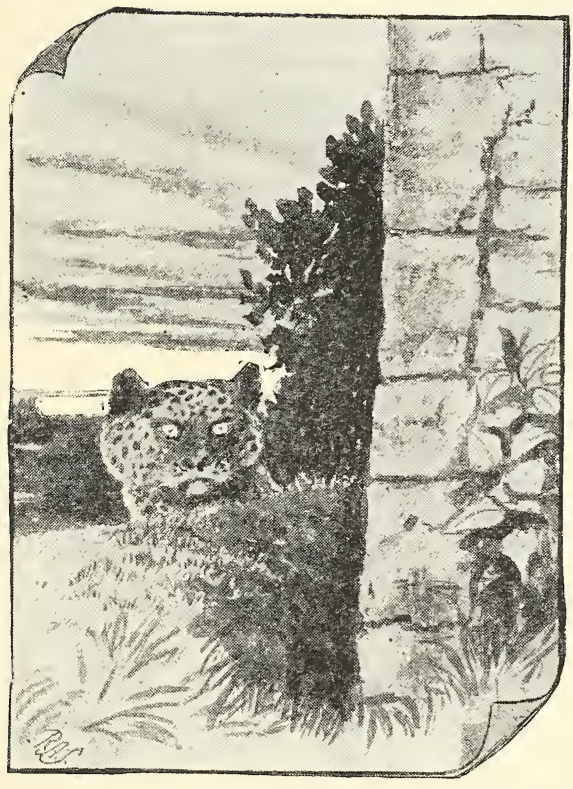

I HAVE never in my life written a tale of sport, or a narrative of personal adventure; but I have read a good many, and I think I know how the thing should be done, so I will turn aside from the peaceful course of these papers and endeavour to give an account of what befell me not long ago.

My friend $H$. and I had just arrived at an out-worn little town, which had once been a place of some im- 
portance, and about sunset, having disposed of urgent work and dismissed our clerks, we went out for a stroll round a fine old fort in the middle of the plain to the east of the town. My friend had three dogs, rowdy little beasts, supposed to be fox-terriers, and I had a respectable and respected old spaniel, which acted as their guide, philosopher and friend. These accompanied us.

As we neared the dark old fort, a pair of great Fish Owls came out of it and flew past us. I remembered finding their nest, nearly two years ago, in a large hollow tree just inside the gate. There was one young one, a goblin in yellow down, with eyes as large as a rupee, and so plentifully stocked with vermin that I made all the haste I could to restore him to his parents and wash my hands of him. I mentioned to $H$. that the natives in the town say that there is generally a small panther in the fort. $H$. ridiculed the idea and insinuated that my shikarree, Banawat Beg, had been playing on my credulity. $\mathrm{H}$. is naturally disputatious, and I have always had a strong, innate passion for the truth, so we were on the borders of an argument, when $\mathrm{H}$. started and exclaimed, "What is that?" I listened and heard a distant sound 
like the sawing of wood. "A panther," I answered, not in the spirit of controversy, but because it really was uncommonly like the voice of a panther. However, it was not repeated, and $\mathrm{H}$. thought it must be some night bird; so we went on our way. As we got round to the east of the fort the walls loomed dark and grand against the western sky, and stopping to admire them, I noticed a stone, or some other object, very like the head and ears of a large cat, on the top of the mound just under the walls. "Look there," I said jocatively, "do you now see the panther inspecting us?" $H$. replied, "I do." At that instant the object moved. "By the AccountantGeneral," cried H., "it is a panther. What shall we do? It will be down on the dogs." In truth, the situation was not a pleasant one. We could not move five yards from where we stood without losing sight of the beast against the black wall, and then it would be at liberty to stalk us in the darkness and take its pick of the dogs. Of course it would take Moses, who is fleshy and tender. We held a hurried council and decided that $H$. should make for the high road as fast as he could, with the dogs, while I should remain where I was and mount guard on the panther. As he wont away, I saw it raise itself and 
look longingly after him: then it turned and looked at me. It clearly saw that it was watched and cursed me in its heart, but dared not advance.

Giving my friend time to get safe away, I began to think what I should do. It was nearly dark now, and I felt that I could not walk home with that blackguard watching me. So I walked slowly towards it, but it did not move. I stopped and shouted at the pitch of my voice, but it gave no sign. I advanced again till I seemed to be within fifty yards of it, but still that round head with two ears remained motionless against the sky. It looked very large at this distance. At last I took up a stone and threw it with all my might. It fell just in front of the brute, and in an instant he sprang to his feet and jumped into the fort ditch. Then I got myself home as fast as I could, and found that $H$. had tied up the dogs and gone out again to look for me.

Next morning we visited the place and could see plainly where the panther, coming down from one of the bastions into the ditch, had made a path through the long grass. We could also trace his course up the side of the ditch to the mound on top of which he had stopped to reconnoitre the plain when we first noticed him. Much against 
the better judgment of our shikarrees, we determined at once to beat the fort for him.

Before going any further with my story it is necessary to give a short description of the place. The fort is built on ground very little higher than the surrounding plain, so that it never owed any strength to its situation; but all that the art of the times could do was done to make up for this disadvantage. Its walls were of solid masonry, very thick and of great height, and at intervals there were strong bastions and towers. There were two strong gates, an outer and an inner, with flanking towers. A deep moat and mound surrounded the whole. Inside, a remarkably fine well supplied the garrison with water, while a temple and a mosque helped them to think that their religious needs were satisfied also. Such was the fort before time took it in hand. Now great trees of the fig tribe tower above the wall, while their roots straggle and sprawl over the masonry, separating and dislodging the massive stones. The "hyssop on the wall," rank grasses and pendant masses of creeping plants, make it difficult to see the fortifications from without. Within, aromatic shrubs, thorn bushes and fruit trees, tied together with the stinging cowitch, make it difficult to walk in any 
direction, while gigantic mango and tamarind trees throw a gloomy shade over the whole. It was simply insanity to attempt to beat for a dangerous beast in such a place, and we must have been infatuated to think of it. Surely it was a case of quem dei perdere volunt priusquam dementant, if ever there was one.

As I have said, both our shikarrees were opposed to the plan, but when we insisted on it, they carried out our wishes loyally. They were two of the most remarkable men whom it has been my lot to meet, and very unlike each other. Tajoob Khan, my friend's lieutenant, was a large-boned, tall man of black complexion, with small beard parted in the middle, silent, cool and self-contained, almost phlegmatic until danger kindled him. He was dressed in a green shikar suit and wore in his belt a dearly beloved hunting knife, with which he had once saved his master's life and killed a tiger, burying it to the hilt in the brute's heart. His grateful master had the trusty blade fitted with a new, richly chased handle, bearing an inscription in Arabic characters to commemorate the event; and Tajoob Khan will never part with that weapon till he parts with life. My man, Banawat Beg, was fair-skinned, small and spare, but supple as a cat. He was dressed in a suit of plain 
khakee, and wore on his head a small cap with flaps to pull over his ears when the wind blew cold. I never saw a native so restless in mind and body as little Banawat Beg. He had an eye like a hawk, and appeared to know every beast, bird and tree in the jungle.

It would be difficult to say which of these men had been present at the death of most tigers, and there was a good deal of jealousy between them, but for once they were fully agreed as to the only practicable way of beating the fort. This was to divide it into two halves by a line of men armed with tom-toms and crackers, and beat down one half first and the other after. We got plenty of men without difficulty, for almost everyone in the town had to avenge the death of a fine goat or a favourite dog; but the tom-toms had all been engaged for a marriage at the house of a wealthy vakeel, and we could not get one. But Banawat Beg, always fertile in resource, went to the coppersmith's lane and hired a hundred kettles and large handies, which when struck with hollow bamboos made an abominable din. As soon as we could get into suitable trees, the beat began, with the usual yelling and shouting so familiar to every shikarree. Above all I could hear the sonorous voice of Tajoob Khan, challenging the 
panther to show his base visage and taunting him about certain scandals affecting the characters of his mother and aunts. Suddenly the word bawg (tiger or panther) rang out in the shrill tone of Banawat Beg and silenced everyone, and I could hear a heavy animal coming down at a brisk trot. The men with the kettles and crackers dropped their apparatus and went up the nearest trees like squirrels. Fortunately one man tried to take his kettle up with him, but it slipped from his grasp and fell upon a large stone just in front of the beast, causing him to double back.

The beaters now began to advance again, and soon I descried the spotted form of a large panther slinking under the bush towards $\mathrm{H}$. He was well posted over a piece of open ground, across which the beast would have to pass. It did so at a gentle trot, and he fired both barrels, but without effect. Then it started off at full speed in my direction. The bushes were so dense that I could not get a glimpse of it, but the noise it made among the fallen leaves let me guess its course exactly, and glancing ahead, I marked a small opening, not more than three inches wide, among the leaves of a thick corrinda bush, behind which I felt sure it would pass. I was right. For a moment its body darkened the hole, and I fired. A scuffle in the grass told that 
the brute was in the throes of death. Reloading, I approached cautiously, and what was my disgust to see a huge hyæna lying on the ground, shot through the heart. Yet I could have sworn that its skin was spotted when I first caught sight of it. Not one of us is secure against the dominion of the imagination over the senses.

The beat was taken up again, but nothing rose except a small jungle cat, which I stopped with a bullet through the head. After giving each of the kettle-wallas a little bamboo bakshees for his cowardice, we beat the other side of the fort, but found nothing. Where was the panther? The general opinion appeared to be that our panther was a hyæna, but Tajoob Khan, coming up, silenced that by showing the head of a goat which he had found in the temple, still fresh and bleeding. "A hyæna," he said, "would have eaten the head first." Suddenly Banawat Beg whispered dekko, and raising our eyes to a tower just above us, we beheld a large round face looking at us over the parapet. I raised my gun, and it disappeared. What was to be done next? It would be madness to attempt to clamber up into the tower, even if it were possible. Banawat Beg solved the difficulty. "Throw up a cracker," he said. So a large Chinese cracker was lighted and slung 
into the tower. A moment's pause, then bang, bang, bang went the cracker, and in an instant, without a sound, an enormous panther cleared the parapet and landed in our midst from a height of twenty feet. We all, without exception, fell flat on our backs. It was the most ludicrous sight I ever saw. There we were, lying on the ground, looking at this great tom cat, with its back arched, its tail erect, its ears thrown back, and its whiskers standing out fiercely. It stood so for a moment, then, with a snarl, bounded away through the thicket. We were up and after it in a moment, laughing outright in our excitement. The incident had changed all our feelings and banished thoughts of danger. We traced it to a dense patch of cactus, and taking our stand at one end, sent the beaters to the other. Out it came like greased lightning, as they say in America. H. fired both barrels, but missed it. I could not fire for fear of hitting the beaters. The sport now became more like rabbit shooting than anything else. From bush to bush the brute rushed, and the pop of my friend's gun was heard every minute. Tajoob Khan did not like this sort of thing and tried to restrain him, but he knocked down Tajoob Khan. I tricd what I could do, but it was useless. He was too excited to listen to reason. Dreading the risk 
to my friend of wounding the panther in such circumstances, I waited for the chance of a sure shot. At last it passed me, and bounding over a high bush, gave a chance. I fired at it in mid-air, aiming for the heart; but the sun was in my eyes, and I only grazed its back. I had done just what I feared. Its snorts and snarls told too plainly that it was getting very angry. At last it took refuge in a recess in the walls, and arching its back, stood at bay, with a very ugly look in its face. H. was in full pursuit, far ahead of us all. Frantically I shouted to him to be cautious, but it was too late. An excellent shot with either gun or rifle, and naturally fearless, he had lost his head. From less than twenty yards he fired both barrels at once. With a fearful roar I saw it dart out upon him. He sprang up a tree, for he was as nimble as a monkey; but he stuck in a fork about ten feet from the ground, and with horror I saw the panther spring upon him and bury its claws in his shoulders. Its weight dragged it slowly down, while its claws ploughed through my poor friend's back. It fell to the ground only to spring again. Twice and thrice the sickening process was repeated. I aimed at the panther's spine, just behind the shoulder, and pulled the trigyer. My last ball cartridge missed fire! Catching 
a kettle from the hand of a beater, I rushed to within three yards of the brute and discharged it at him with all my force. It struck him full on the head and must have halfstunned him, for he rushed sulkily under the old archway again. Then I looked up for my friend. He was reduced to ribbons. Shreds of cloth and long strips of skin and flesh floated promiscuously upon the wind, which now began to howl through the branches of the trees. Madness took possession of me. I had fired my last ball, but I remembered how Sir Samuel Baker, in the same predicament, dropped a charging buffalo with a handful of small change. So I dived my hand into my pocket. There was no money there, only a penknife with a blade at each end. This would do. Anything would do. I took a cartridge loaded with small shot and drove one blade into it, so that the other blade pointed outwards, then putting it into my right barrel, I advanced towards the panther. "Now do the same to me. Ha! Ha!" I cried, like an exultant maniac. The brute arched his back and prepared to spring. Then I fired. When the smoke cleared away, he was lying motionless on the ground. One blade and half the handle of the penknife stood out of his right eye, the other blade was in his brdin. Fiercely I said to the men 
"Oothao," and left him. Then we collected the shreds of my poor friend, and putting them into a coolie's basket, wended our way home in stern silence. The panther was found to measure exactly seven feet and one inch, but the measurement was worthless, as poor $\mathrm{H}$. had cut off nearly the whole of its tail with his first shot.

It is not usually done, but I may mention that the events narrated in the second part of this story never really happened, because we wisely decided not to beat for the panther, but to sit up for him over a live goat. We did so, but it was a very tame affair compared with the adventure which I have described. And after all you cannot limit a shikarree's adventures to things that have actually happened. It would rob the sporting world of half its best books, and many a sportsman hero of half his reputation. However, I promise not to do it again.

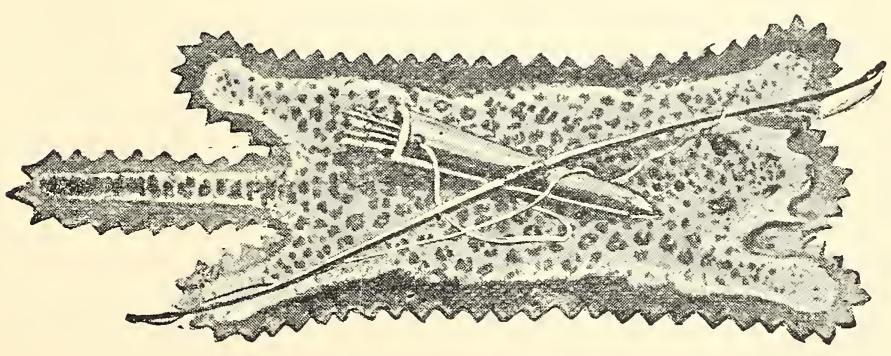


LONDON :

PRINTED BX WILLIAM CLOWES AND SONS, LIMITED, DUKE STREET, STAMFORD STREET, S.E., AND GREAT WINDMILL STREET, W.

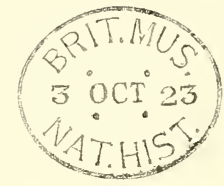


BY THE AUTHOR OF "THE TRIBES ON MYY FRONTIER,' "BEHIND THE BUNGALOW," etc., etc.

\section{THE FIVE WINDOWS OF THE SOUL By E. H, AITKEN,}

Ft Dopular Fecount of the thiman schses.

Crown Svo., cloth, 6s. 



\section{COMPLETE IN 24 VOLS., £12 12s. NET.}

\section{The Works of . .}

\section{A J O R \\ G. J. Whyte=Melville \\ An Edition de Luxe.}

Edited by the Rt. Hon. Sir HERBERT MAXWELL, Bart., M.P.

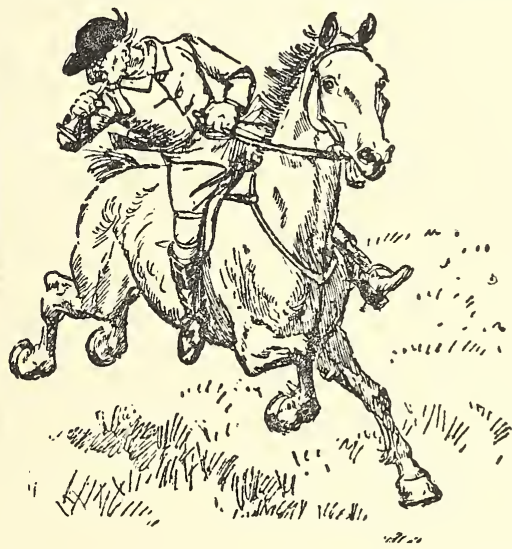

The Volumes are printed from new type on handmade paper, specially manufactured for this edition, and handsomely bound in buckram, with gilt tops. Demy 8vo., ,Coloured Frontispiece on Japanese vellum, and Full-page Illustrations by well-known Artists. Limited to 1,050 Sets.

\section{HUGH THOMSON, H. M. BROCK, G. H. JALLAND, HARRINGTON BIRD, CECIL ALDEN, C. E. BROCK, BERNARD PARTRIDGE, EDMUND CALDWEL.L, \&c.}

"The edition has everything to recommend it externally." - The Times.

"Altogether a pleasure to read."-The Field.

"The tasteful buckram volumes are worthy of the man and the matter in them."-Pall Mall Gazette.

"Fulfils every requirement of the book-lover, in paper, type, illustrations, and binding."-Saturday Reviere.

W. THACKER \& CO., 2, CREED LANE, LONDON.

THACKER, SPINK \& CO., CALCUTTA \& SIMLA. 

. A SELECTION FROM THE.

\section{PUBLICATIONS}

W. THACKER \& CO. 2, CREED LANE, LONDON, E.C. THACKER, SPINK \& CO. CALCUTTA AND SIMLA, INDIA.

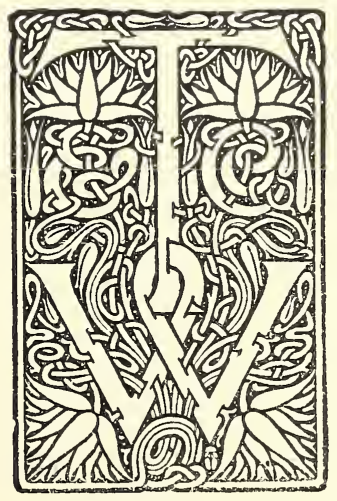

.. W. THACKER \& CO...

2, CREED LANE, LUDGATE HILL, LONDON, E.C. No. 86. 1905 . 


\section{CONTENTS.}

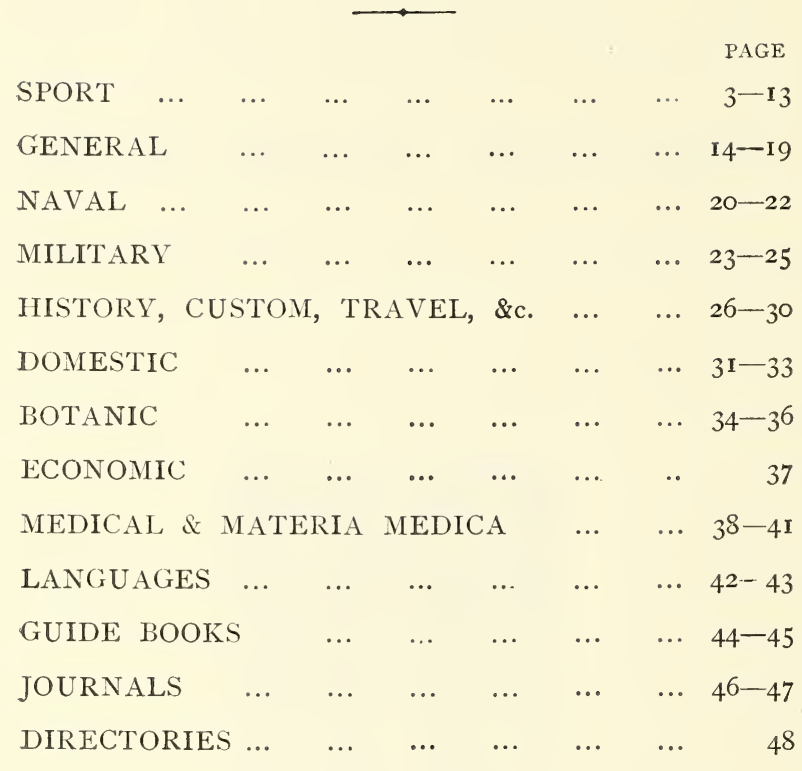

Separate Catalogue of Law Publications sent on application. 
Third Edition. Demy 4to. 36 Plates and Map. £I Is. net. Rs. I5.I2.

\section{LARGE GAME SHOOTING}

IN THIBET, THE HIMALAYAS, NORTHERN AND CENTRAL INDIA.

\section{By Brig.-General ALEX. A. A. KINLOCH.}

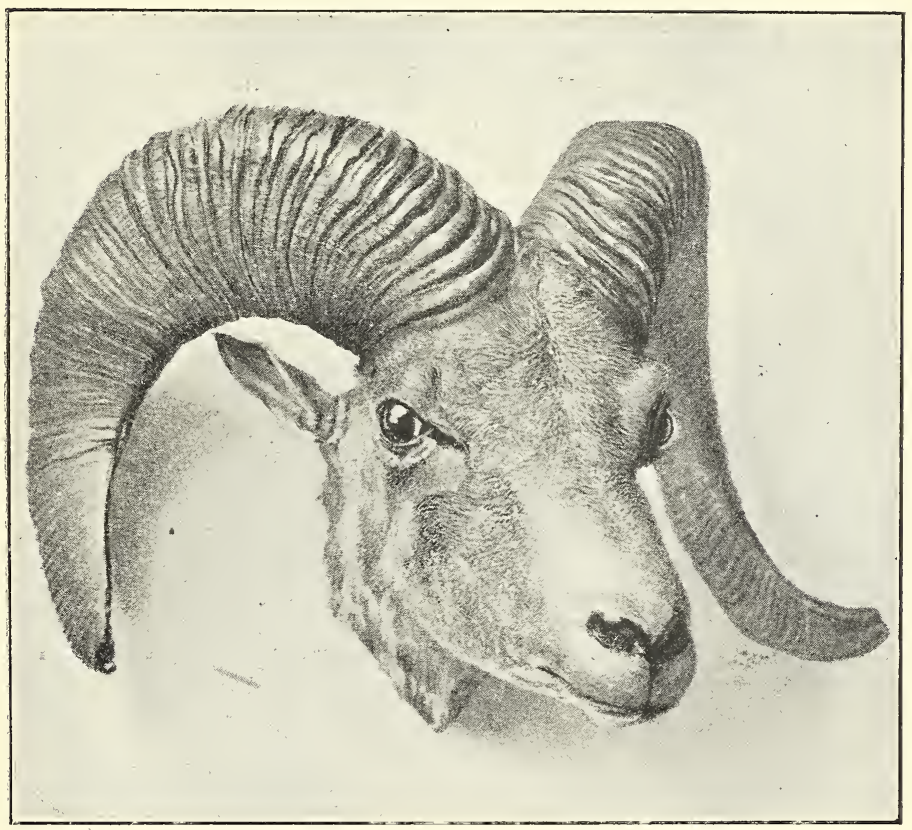

NYAN OR GREAT THIBETAN SHEEP.-Ovis Hodgsonii.

Times.- "Colonel Kinloch, who has killed most kinds of Indian game, small and great, relates incidents of his varied sporting experiences in chapters which are each descriptive of a different animal. The photogravures of the heads of many of the animals, from the grand gaur, popularly miscalled the bison, downwards, are extremely clever and spirited."

Graphic.- "This splendidly illustrated record of sport. . . The photogravures, especially the heads of the various antelopes, are life-like; and the letterpress is very pleasant reading." 
Second Edition. Demy 8vo., cloth, Ios. 6d. Rs. 7.1.4.

\section{BULLET AND SHOT \\ IN INDIAN FOREST, PLAIN, AND HILL. \\ WITH HINTS TO BEGINNERS IN INDIAN SHOOTING. \\ By C. E. M. RUSSELL}

(late Senior Deputy Conservator of Forests, Mysore Service).

\section{List of Contents.}

The Indian Bison-Bison Shooting-Hints to Beginners-The Wild Buffalo, the Yak, and the Tsine-The Tiger-Incidents in Tiger Shooting-The Panther, Hunting Cheetah, Clouded Leopard, Snow Leopard, and Indian Lion-The Chief Bears of India-The Indian Elephant-The Deer of India and the Himalayas-The Neilgherry Wild Goat-The Wild Goats of Cashmere and Ladakh-The Wild Sheep of India-The Rhinacerotidæ and Suidæ of India - Small Animals worth Shooting-Game Birds and Wild Fowl of IndiaPoachers and Nuisances-Camp Equipment, Outfit, Servants, etc.-Rifles, Guns, Ammunition, etc. - Hints on Skinning and the Preservation of Trophies, etc., etc.

Saturday Review._- "We have nothing but praise for his accuracy and for:the value of his practical advice. . . . Not a few of the chapters are very attractive reading, being full of exciting anecdote and picturesque reminiscences. . . . His chapters on forest campaigning, camp equipment, and sporting batteries deserve careful attention.'

Civil and Military Gazette (Lahore).-“. . . Cannot fail to appeal to. sportsmen of every standing, from the veriest tyro, to whom it will prove particularly useful, to the oldest hand at the game. . . . The general excellence and completeness of the book should ensure it the position of a standard work."

\section{SEONEE; \\ OR, CAMP LIFE ON THE \\ SATPURA RANGE. \\ A Tale of Indian Adventure. \\ By R. A. STERINDALE, IF.R.G.S., F.Z.S. \\ Illustrated by the Author.}

Second Edition. $\quad$ Post 8vo., 8s. 6d. Rs. 6.6.

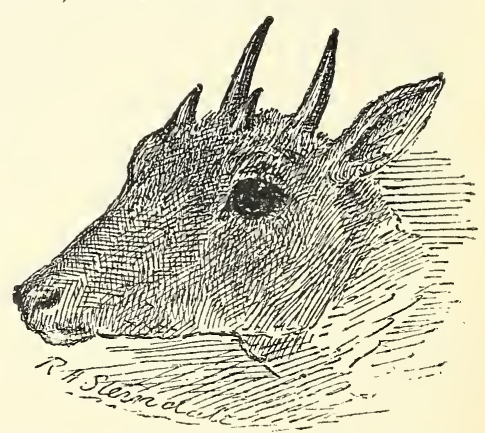

With an Appendix containing a brief Topographical and Historical Account of the District of Seonee, in the Central Provinces of India. 
Imperial I6mo., cloth, 580 pages, I2s. $6 d$. Rs. Io.

\section{A NATURAL HISTORY OF THE MAMMALIA OF INDIA,}

BURMAH AND CEYLON.

\section{By R. A. STERNDALE, F.R.G.S., F.Z.S. \\ With 170 Illustrations by the Author and others.}

The geographical limits of the present work have been extended to all territories likely to be reached by the sportsman from India. It is copiously illustrated, not only by the author himself, but by careful selections made by him from the works of well-known artists.

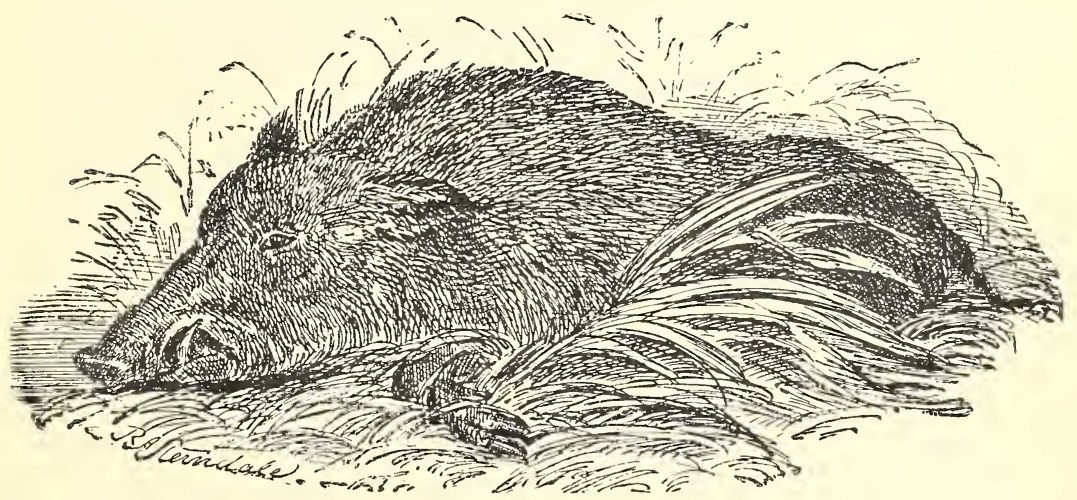

Knowledge.- " It is the very model of what a popular natural history should be."

Saturday Review.- " Full of accura te observations, brightly told."

Athencum._-"The results of a close and sympathetic observation."

The Times. - "The book will, no doubt, be specially useful to the sportsman, and indeed has been extended so as to include all territories likely to be reached by the sportsman from India."

The Daily News. - "Has contrived to hit a happy mean between the stiff scientific treatise and the bosh of what may be called anecdotal zoology." 
Second Edition. Crown 8vo., cloth, I50 pages, 3s. $6 d$. net. Rs. 2.8.

\title{
USEFUL HINTS TO YOUNG SHIKARIS
}

\section{ON THE GUN AND RIFLE.}

\author{
By the "LITTLE OLD BEAR."
}

Containing information on every subject necessary for the young Shikarfrom his rifle, gun, and ammunition to his camp kit and dress.

Fcap. 8vo., cloth, 5s. net. Rs. 3.8.

\section{THE SPORTSIMAN'S MANUAL.}

In Quest of Game in Kullu, Lahoul, and Ladak to the T so Morari Lake, with Notes on Shooting in Spiti, Bara Bagahal, Chamba, and Kashmir, and a Detailed Description of Sport in more than Ioo Nalas. With 9 Maps.

By Lt.-Co1. R. H. TYACKE, late H.M.'s 98th and 34th Regiments.

Fourth Edition. Demy 8vo., cloth, 7s. 6d. net. Rs. 5.

\section{THE TOURIST AND SPORTSMAN'S \\ GUIDE TO KASHIMIR \& LADAK.}

By A. E. WARD

(Bengal Staff Corps).

Giving in a small compass all the principal routes in Kashmir and Ladakwith information where sport may be obtained; the Game Laws of the country and useful hints as to Camp Kit required and the supplies obtainable.

Oblong folio $\left(\mathrm{I} 8 \times \mathrm{I}_{4}\right)$, cloth, I2s. $6 d$. net. Rs. IO.

\section{DENIZENS OF THE JUNGLES.}

A SERIES OF SKETCHES OF WILD ANIMALS, ILLUSTRATING THEIR FORM AND NATURAL ATTITUDE.

With Letterpress and Description of each of the I2 Plates.

By R. A, STERNDALE, F.R.G.S., F.Z.S. 
Third Edition. Demy 8vo., cloth I5s. Rs. II.4.

\section{THE ROD IN INDIA.}

BEING HINTS HOW TO OBTAIN SPORT, WITH REMARKS ON THE NATURAL HISTORY OF FISH AND THEIR CULTURE.

By H. S. THOMAS, F.L.S. (Madras Civil Service, Retired), Author of "Tank Angling in India."

With numerous full-page and other Illustrations.

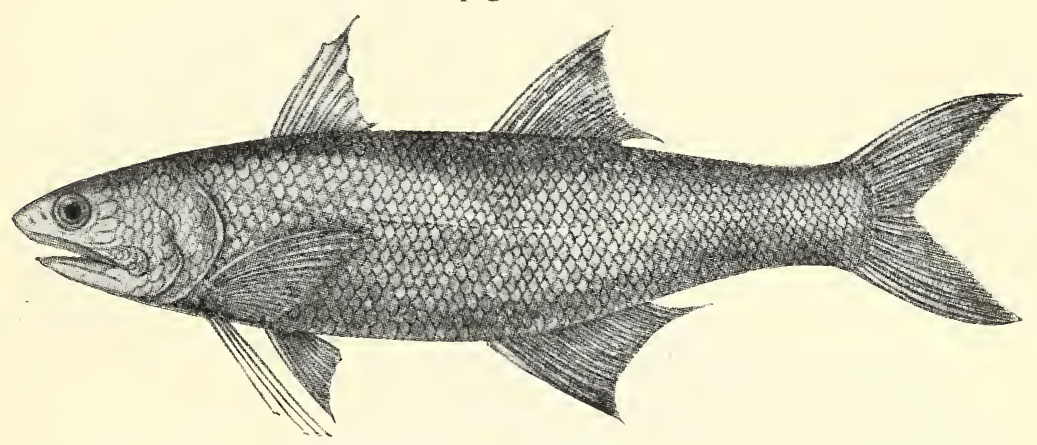

Field._" A masterly treatise on the art of angling."

Spectator.- "A more complete guide to its subject than could be found" elsewhere."

Illustrated Sporting and Dramatic News. - "His book has been for years a standard work. Perhaps, without injustice to others, it may be described as the standard work upon Indian angling."

Field.- "To the angler going out to India, Mr. Thomas's book will be a necessary part of his outfit."

Crown 8vo., cloth. Rs. 4.

\section{ANGLING ON THE KUMAON LAKES.}

WITH A MAP OF THE KUMAON LAKE COUNTRY AND PLAN OF EACH LAKE.

By Deputy Surgeon General W. WALKER.

Hayes' Sporting News. - "Written with all the tenderness and attention to detail which characterizes the followers of the gentle art." 
: Fourth Edition. Super royal 8vo., cloth gilt, $33^{8}$ pages, 2Is. net. Rs. I8.6.

\section{GAME, SHORE, AND WATER BIRDS OF INDIA.}

\section{WITH ADDITIONAL REFERENCES TO THEIR ALLIED SPECIES IN OTHER PARTS OF THE WORLD.}

\section{By Colonel A. LE MESSURIER, C.I.E., F.Z.S., F.G.S.}

(late Royal Engineers), Author of

"Kandahar in 1879," "From London to Bokhara and a Ride through Persia."

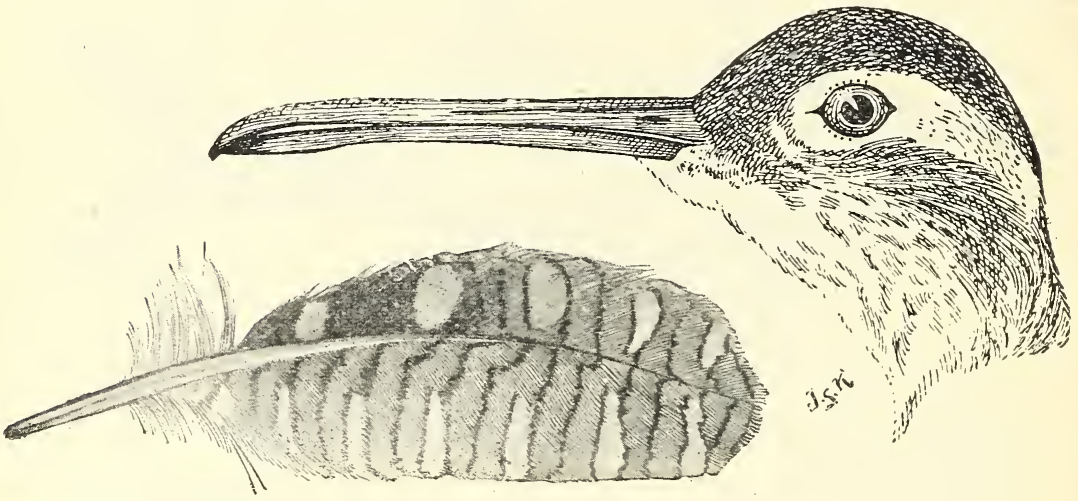

With I80 natural size Illustrations from actual specimens.

A Vade Mecum for the Sportsman, embracing all the Birds at all likely to be met with in a Shooting Excursion.

\section{Reviews of Third Edition.}

Nature.-- "Colonel Le Messurier writes as a field naturalist for field naturalists and sportsmen without any great pretensions to scientific knowledge, but there is no doubt that all naturalists will gain useful hints from this little volume, which is profusely illustrated with wood cuts giving the characteristic features of most of the species."

Knowledge.- "Compact in form, excellent in method and arrangement, and as far as we have been able to test it, rigidly accurate in details, Colonel Le Messurier's book should become the vade mecum of every sportsman and naturalist whom duty or pleasure may compel to visit India."

Madras Times.-" Neatly and handily bound, well printed and clearly illustrated, the book undoubtedly fills a void in the literature of the day. The work is well arranged, and will probably fully answer the requirements of even a veteran sportsman." 
Crown 8vo., paper cover, $2 s .6 d$. net. Re. I.I2.

\title{
THE BIRDS OF CALCUTTA.
}

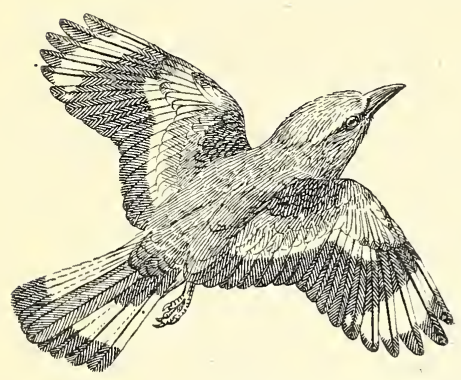

\author{
A SERIES OF SHORT \\ HUMOROUS BUT FAITHFUL \\ DESCRIPTIONS OF THE \\ COMMON BIRDS OF \\ CALCUTTA.
}

\section{By FRANK FINN, F.Z.S. M.B.O.U.}

(late Deputy Superintendent

Calçutta Museun).

With Illustrations by H. GOODCHILD.

II Field.- "There is a good deal of bird life to be observed in and around Calcutta, to which Mr. Finn's little book will serve as a useful guide, especially as it has some good illustrations by Mr. Herbert Goodchild."

Crown 8vo., cloth.

\section{GARDEN AND AVIARY BIRDS OF INDIA.}

A HANDBOOK FOR FIELD NATURALISTS AND BIRD FANCIERS.

With Illustrations drazen from life.

By FRANK FINN, F.Z.S., M.B.O.U.

[Nearly Ready.

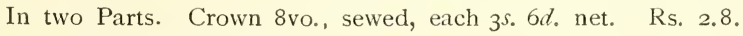

HOW TO KNOW-

\section{THE INDIAN DUCKS. THE INDIAN WADERS.}

\section{By FRANK FINN, F.Z.S., M.B.O.U.}

\author{
(late Deputy Superintendent Calcutta Museum).
}

Nature.- "We have nothing but commendation for this excellent little volume." 
Second Edition. Imperial I6mo., cloth, 8s. $6 d$. net. Rs. $7 \cdot 8$

THE COMMON SENSE OF RIDING.

\title{
RIDING FOR LADIES.
}

\section{WITH HINTS ON THE STABLE. By Mrs. POWER O'DONOGHUE.}

\author{
With 68 Illustrations by A. ChANTREy CORBOUld.
}

This able and beautiful Volume forms a standard on the subject, and is one which no lady can dispense with.

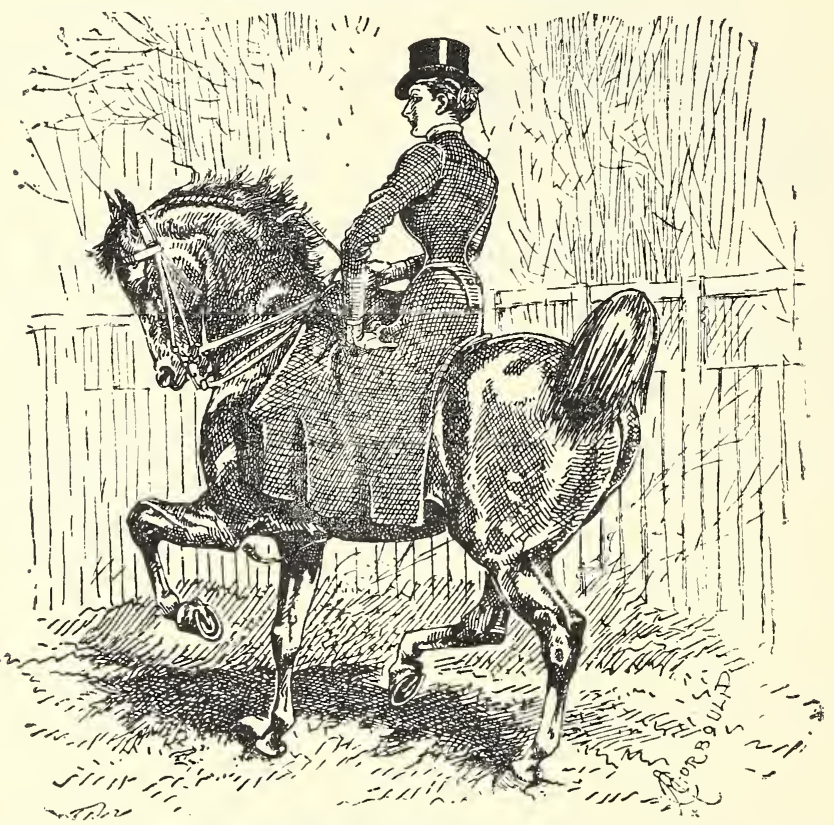

\section{Reviews of First Edition.}

Punch.- "Mrs. Power O'Donoghue (more power to her-not that she wants it) shows no sign of 'falling off!' Indeed, she shows her readers how to become riders, and to stick on gracefully. She sketches her pupils 'in their habits as they ride,' and gives them a bit of her mind about bits, and tells them about spurs on the spur of the moment."

Field.- "Mrs. O'Donoghue is great on the subject of a lady's riding-dress, and lays down useful information which should not be forgotten. . . . From first to last she never errs on the side of anything approaching to bad taste, which is more than can be said for some equestriennes."

Daily News.- "It is characteristic of her book, as of all books of any value, that it has a distinctive character. Sound common sense, and a thoroughly practical way of communicating instruction, are its leading traits." 
Second Edition. Crown 8vo., Is, $6 d$. net. Re. ז.

\section{NOTES ON STABLE MANAGEIMENT.}

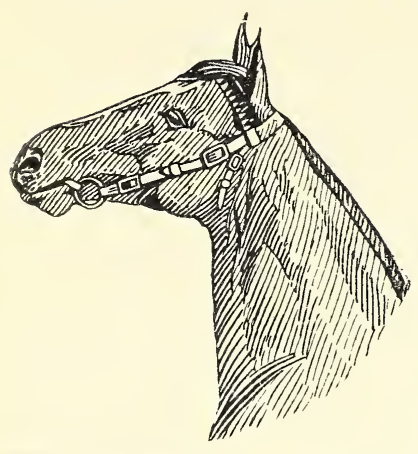

WITH GLOSSARY OF HINDUSTANI WORDS.

\author{
By Vety. Col. J. A. NUNN, \\ F.R.C.V.S., C.I.E., D.S.O.
}

This little work is written specially to give the new arrival in India some idea as to the management of his horses, especially those who are getting up a stable for the first time. It contains invaluable hints and information, only to be learned in the ordinary way by long and often bitter experience.

Indian Daily Nerus. - "The notes are eminently practical, and give sound advice on everything pertaining to the proper care of horses, such as can be utilized by the uninitiated to the best advantage."

Fifth Edition. Fcap. 8vo., cloth, 3s. net. Rs. 2.

\section{INDIAN HORSE NOTES. \\ By Major C}

An Epitome of Useful Information arranged for ready reference on Emergencies, and specially adapted for Officers and Mofussil Residents. All technical terms explained and simplest remedies selected.

\section{Crown 8vo., cloth, 3s. net. Rs. 2 。 \\ STATION POLO.}

THE TRAINING AND GENERAL TREATMENT OF POLO PONIES, TOGETHER WITH TYPES AND TRAITS OF PLAYERS.

By Lieut. HUGH STEWART (Lucifer).

\section{Contents.}

THE POLO PONY: The Raw Pony-Preliminary Training-First Introduction -Stable Management - Tricks - Injuries - Shoeing. STATION POLO : Station Polo, How shall we Play?-The Procrastinator-The Polo ScurryIdiosyncrasies-Types-Individual $v$. Combined Tactics-Odds and Ends.

Fcap. 8vo., limp cloth, Is. $6 d$. net. Re. I.

\section{GUIDE TO EXAIINATION OF HORSES FOR SOUNDNESS.}

A HANDBOOK FOR STUDENTS AND BEGINNERS.

By J. MOORE, F.R.C.V.S., Army Vety. Dept. 
Crown 8vo., cloth, 6s. Rs. 4.8 .

\section{DOGS FOR HOT CLIMATES.}

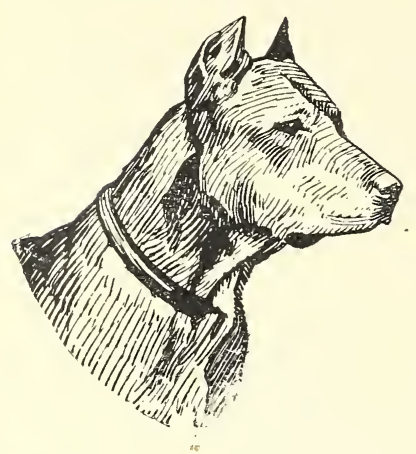

A Guide for Residents in. Tropical Climates as to suitable Breeds, their respective Uses, Management, and Doctoring.

\section{By VERO SHAW and Captain M. H. HAYES.}

With 24 Illustrations from Photographs and Drawings.

Indian Planters' Gazette. - "The authors of 'Dogs for Hot Climates' show in a concise practical way how to treat dogs, and what breeds best stand hot climates. The book should be on every one's table, for sensible treatment will save the life of many a valuable and much-loved pet."

Seventh Edition. Fcap. 8vo., cloth, 2s. 6d. net. Re. r.8.

\section{INDIAN NOTES ABOUT DOGS.}

THEIR DISEASES AND TREATMENT.

\section{By Major C—.}

Contents.

Medical Treatment-Rules for Feeding-Prescription3-Diseases of DogsDescription of Various Breeds-Advice on the Importation of Dogs to India-Hindustani Vocabulary.

Crown 8vo., cloth, 4 s. 6 d. net. Rs. 3 .

\section{THE MANAGEMENT AND BREEDING OF DOGS IN INDIA,} AND THE POINTS TO BREED FOR.

\section{By KADER.}

(Asste. of the English Kennel Club).

A sian.- "A book of this kind, in a country where good and experienced judges are scarce, and where reference to standard authority is often needed, was much wanted." 
Demy 8vo., gilt tops. Twenty-four Volumes, complete, fir 125 . net.

\section{THE EDITION DE LUXE OF THE WORKS of G. J. WHYTE-MELVILLE.}

Edited by the Right Hon. Sir HERBERT MAXWELL, Bart., M.P.

The Volumes are printed from new type on hand-man paper, specially manufactured tor this Edition, and handsomely bound in buckram, with gilt tops. Coloured Frontispiece on Japanese vellum, and full-page Illustrations by well-known Artists.

I. RIDING RECOLLECTIONS. Illustrated by HUGH THOMSON.

II. KATERFELTO. Illustrated by G. H. JALLAND.

III. UNCLE JOHN. Illustrated by E. Caldwell and and H. M. BROCK.

IV. MARKET HARBOROUGH. Illustrated by HUGH THOMSON and Finch Mason.

V. CONTRABAND. Illustrated by Bernard Partridge.

VI. M OR N. Illustrated by C. E. BROCK.

VII. TILBURY-NO-GO. Illustrated by E. CALDWELL.

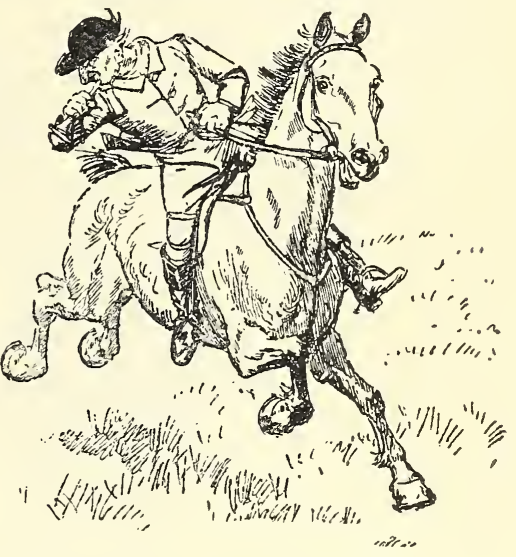

VIII. SONGS AND VERSES, and BONES AND I. Illustrated by H. M. BROCK.

IX. BLACK, BUT COMELY. Illustrated by H. M. BRock.

X. THE BROOKES OF BRIDLEMERE. Illustrated by FRED ROE.

XI. THE WHITE ROSE. Illustrated by H. BiRD.

XII. ROY'S WIFE. Illustrated by CECIL ALDEN.

XIII. SATANELLA. Illustrated by G. H. JALland.

XIV. DIGBY GRAND. Illustrated by H. M. BROCK.

XV. SARCHEDON. Illustrated by HARRINGTON BIRD.

XVI. ROSINE, and SISTER LOUISE. Illustrated by H. M. ВRоск.

XVII. KATE COVENTRY. Illustrated by H. M. ВROCK.

XVIII. CERISE. Illustrated by H. M. BROCK.

XIX. QUEEN'S MARIES. Illustrated by G. H. JALlAND.

XX. HOLMBY HOUSE. Illustrated by G. H. JALland.

XXI. GENERAL BOUNCE. Illustrated by H. M. BROCK.

XXII. GLADIATORS. Illustrated by HARRINGTON Bird.

XXIII. GOOD FOR NOTHING. Illustrated by H. M. BROCK.

XXIV. THE INTERPRETER. Illustrated by H. M. BROCK.

Standard.- "He made the sporting novel something so entirely different to what it had been, that he must be recognised as the originator of a new species, more elevated, more refined, and more largely imbued with the spirit of modern society."

Times. - "The edition has everything to recommend it externally."

Times.- "Good paper and type and a good serviceable binding."

Field.-" Altogether a pleasure to read."

Saturday Review.- "Fulfils every requirement of the book-lover in paper, type, illustrations, and binding."

Truth.- "Has every claim to be considered an edition de luxe." 
Large Fcap. (I7 $\times$ II $)$, bound art cloth, 2Is. net. Rs. I8.6.

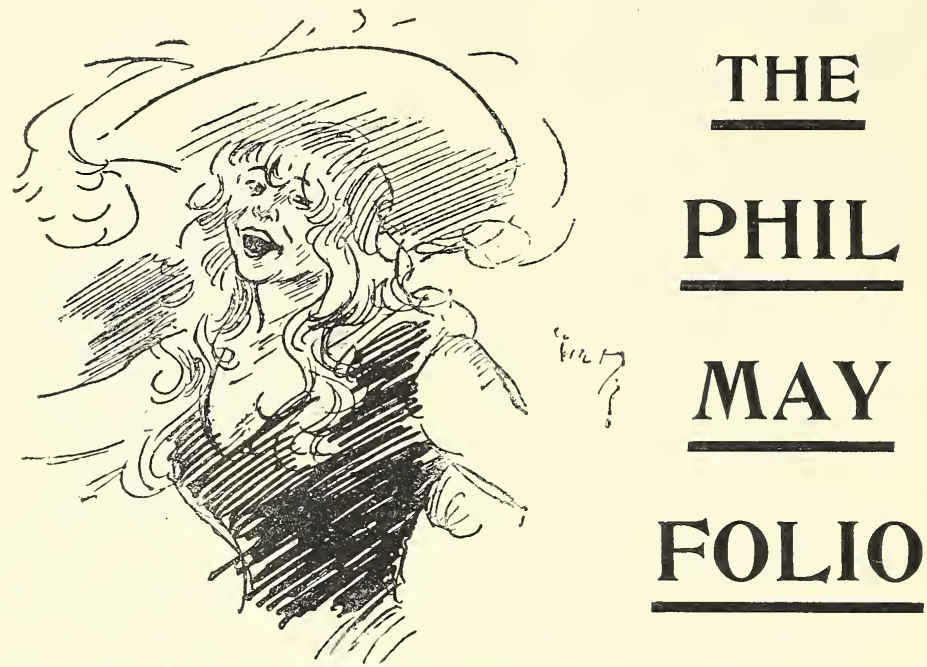

\section{OF CARICATURE DRAWINGS \& SKETCHES}

In Line Block, Half-Tone, and Photogravure.

The Folio includes about 250 Drawings by the late Artist, largely selected by himself from Phil May's Annual as representing his best efforts in various styles. A number of Sketches are also given which have never before been published. The Drawings are arranged in fourteen groups, as follows, each group being preceded by a brief comment:-

I. Personages and Celebrities-2. Costers and Cockneys-3. Brother Brushes-4. The Bars and the Streets-5. Character Studies6. Within and Without the Ghetto-7. Types I Have Met; and Things we See when we come out without Our Gun-8. Among the Thespians-9. Studies and Sketches Abroad-ro. With the Children -II. By the Sea-I2. On the Country-side-I3. Sporting SketchesI4. Irish and Scottish.

A Biography by a personal friend and a full-page portrait of the Artist in Photogravure, are important features of the book.

Graphic._- "Among the many collections of drawings by this gifted artist which have appeared, this is one of the best we have seen, the various phases of life which his pencil loved to depict being all well represented." 
PUBLISHED YEARLY.

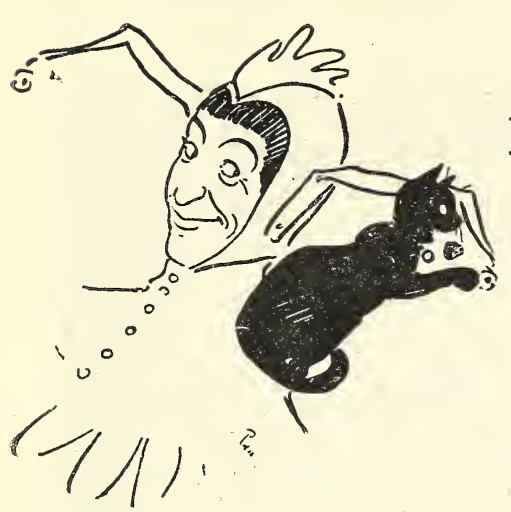

PRICE ONE SHILLING.

\section{PHIL MAY'S WINTER}

\section{ANNUAL.}

ILLUSTRATED ONLY BY

PHIL MAY.

This Publication contains the bright, well-known, clever, and humorous Sketches of the late Phil May, and an attractive selection of Stories by Popular Authors.

\section{Also the following Back Numbers:-}

\begin{tabular}{|c|c|c|c|c|c|}
\hline I 896 & $2 s .6 d$. net. & I 899 & .. & .. & $5^{s}$. net. \\
\hline I 897 & $2 s, 6 d$. net. & I 900 & $\ldots$ & $\ldots$ & 2s. net. \\
\hline 98 Summer . & $\ldots \quad 2 s$, net. & I $90 \mathrm{I}$ & $\ldots$ & $\ldots$ & ${ }_{5}^{\text {s. net. }}$ \\
\hline Winter & $\begin{array}{l}\ldots \quad 3 s . \text { net. } \\
\text { r } 903 \text { and } 1904\end{array}$ & 1902 & $\begin{array}{l}\cdots \\
\text { rs. net. }\end{array}$ & $\ldots$ & Is. net. \\
\hline
\end{tabular}

I6mo., cloth, Is. $6 d$. net. Re. I.

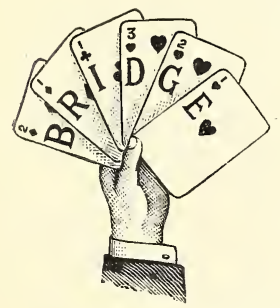

\section{ELEMENTARY BRIDGE. By "GRIMM."}

\section{A NOTEBOOK FOR BEGINNERS. Contents.}

Explanation of 'Term -- General Rules - Offensive Declarations - Defensive Declarations - LeadsPlay-Points, \&c.

Pioneer._- "This little handbook is just what its title claims for it-a note-book for beginners-and is in as handy a form as could well have been desired." 
Third Impression. Demy 8vo., cloth gilt, 300 pages, 5s. net. Rs. 4.6.

\section{A S T R O N O M Y}

WITHOUT A TELESCOPE.

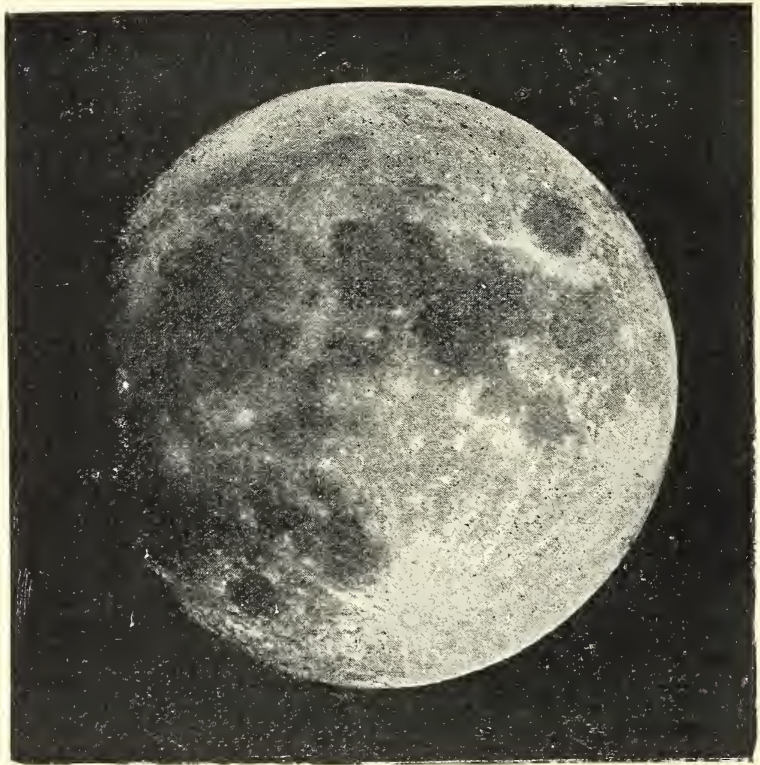

:By E. WALTER MAUNDER, F.R.A.S.

(Of the Royal Observatory, Greenwich).

An Introduction to the Knowledge of the Constellations, and to the Study of the Heavens with the Unassisted Sight.

Fully Illustrated with Full-page Plates, and with Maps and Charts for Identifying the Constellations and the principal Stars, and twelve Star Maps, forming a

COMPLETE CELESTIAL ATLAS, together with a FULL INDEX OF STARS, PLANETS, and CONSTELLATIONS.

Standard.-_ Just the book for a person of ordinary education, who wants to be taught something of the more easily observed wonders of that science, and it has the advantage of being written in a very clear and attractive style."

Daily News. - "Mr. E. W. Maunder has done more than any other astronomer living to show how the study of his favourite science may be pursued without the aid of the telescope or other instruments. . . . An attractive and instructive book, which ought to make many amateur astronomers." 
Seventh Edition. Crown 8vo., cloth, 6s. Rs. 4.8.

\section{THE TRIBES ON MY FRONTIER AN INDIAN NATURALIST'S FOREIGN POLICY. By EHA.}

With Fifty Illustrations by F.C. MACRAE.

In this remarkably clever work there are most graphically and humorously described the surroundings of a Mofussil bungalow. The twenty chapters embrace a year's experiences, and provide endless sources of amusement and suggestion.

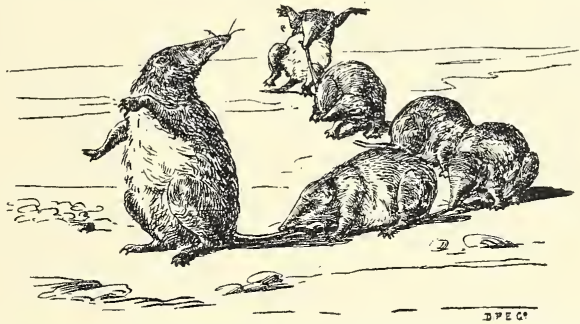

Knowledge.- "This is a delightful book, irresistibly funny in description and illustration, but full of genuine science too. . . There is not a dull or uninstructive page in the whole book."

Second Edition. Crown 8vo., cloth, 6s. Rs. 4.8.

\section{A NATURALIST ON THE PROWL。 By EHA.}

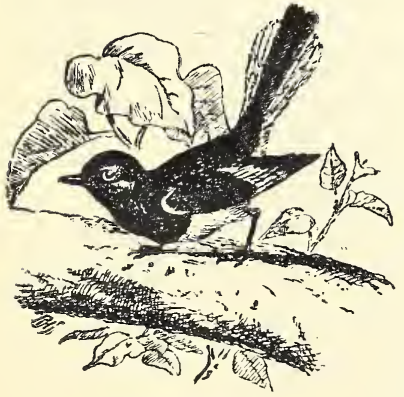

MAGPIE ROBIN.

With Eighty Illustrations by

R. A. STERNDALE, F.R.G.S., F.Z.S

In this volume the Author conducts his readers to the Jungles and Country round the Home, and with genial humour and practised science teaches the interesting art of "How to observe" the structure and habits of Birds, Beasts, and Insects.

Daily Chronicle. - "It is one of the most interesting books upon Natural History that we have read for a long time. It is never dull, and yet solid information is conveyed by nearly every page." 
T'HACKER, SPINK \& CO., CALCU'T'A.

Eighth Edition. Crown 8vo., cloth, 6s. Rs. 4.8.

\section{BEHIND THE BUNGALOW. \\ By EHA.}

With Fifty-three Illustrations by F. C. MACRAE.

As The Tribes on My Frontier graphically and humorously described the Animal Surroundings of an Indian Bungalow, the present work portrays with much pleasantry the Human Ufficials

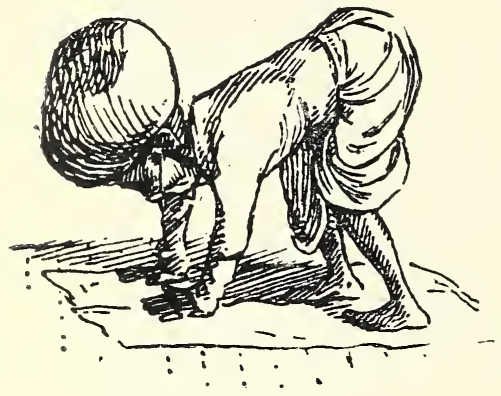
thereof, with their peculiarities, idiosyncrasies, and, to the European, strange methods of duty.

The World.- "'These sketches may have an educational purpose beyond that of mere amusement; they show through all their fun a keen observation of native character and a just appreciation of $i \hat{\imath}$."

The Graphic.-“"Anglo - Indians will see how truthful are these sketches. People who know nothing about India will delight in the clever drawings and the truly humorous

" A LitTle islope." descriptions."

Seventh Edition. Crown 8vo., cloth gilt, 6s. Rs. 4.8.

\section{TWENTY-ONE DAYS \\ IN INDIA.}

BEING THE TOUR OF SIR ALI BABA, K.C.B.

\section{By GEORGE ABERIGH MACKAY.}

With Thirteen full-page Illustrations.

Land and Water._-"The scores of letters to 'Vanity Fair,' which created such a sensation in India some years ago, have maintained their popularity in a fashion which their cleverness thoroughly deserves."

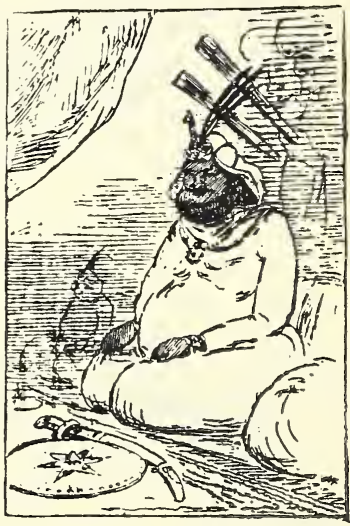

This latest edition of the most famous Satire ever written on Indian Society and Social Life is absolutely complete The Illustrations specially drawn for the expensive edition all appear in this impression. 
Tenth Edition. Crown 8vo., cloth gilt, $6 s$. Rs. 4.8 .

\section{LAYS OF IND.}

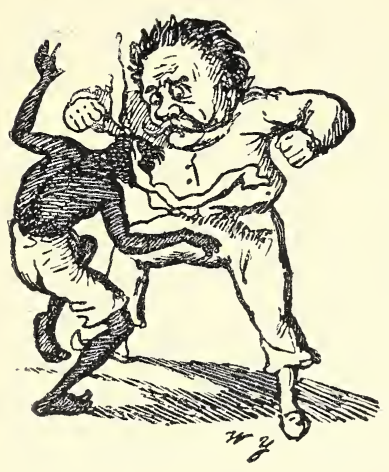

COMIC, SATIRICAL, AND DESCRIPTIVE.

Poems Illustrative of Anglo-Indian Life. By ALIPH CHEEM.

ILLUSTRATED BY THE AUTHOR, LIONEL INGLis, R. A. STERndale, AND OTHERS.

The World.- "This is a remarkably bright little book. In a few of the poems the jokes, turning on local names and customs, are somewhat esoteric ; but taken throughout, the verses are characterised by high animal spirits, great cleverness, and most excellent fooling."

Liverpool Mercury._-"One can readily imagine the merriment created round the camp fire by the recitation of the 'Two Thumpers,' which is irresistibly droll."

Scotsman.-"The 'Lays' are not only AngloIndian in origin, but out-and-out Anglo-Indian in subject and colour."

Fifth Edition. I2mo., sewed, Is. 6d. net. Re. I.

\section{ONOOCOOL CHUNDER MOOKERJEE.}

\section{A MEMOIR OF THE LATE JUSTICE ONOOCOOL CHUNDER MOOKERJEE.}

\section{By M: MOOKERJEE.}

The Tribes on my Frontier.-." The reader is earnestly advised to procure the life of this gentleman, written by his nephew, and read it."

Fcap. 8vo., Is. 6 d. net. Re. I.

\section{INDIA IN 1983.}

This little book was originally written at the time of the Ilbert Bill agitation; it gives a farcical account of an imaginary evacuation of India by the British and the subsequent Government by a Babu Raj.

Indian Daily News. - "Instructive as well as amusing."

t- Times of India. - "There is not a dull page in the hundred and thirty-seven pages of which it consists."

Demy 8vo., cloth, 6s. net. Rs. 4.8.

\section{ANIMALS OF NO IMPORTANCE.}

\section{A SERIES OF HUMOROUS . ESSAYS ON SOME OF THE COMMON BIRDS, BEASTS, AND INSECTS OF INDIA.} By D. DEWAR, I.C.S.

Nature.- "We may commend the work as an excellent practical example of "Nature Teaching.'

Indian Daily News. - "The sketches are brightly and'cleverly written, and there is a ripple of humour running throughout them, which makes them pleasant and amusing reading." 


\section{NAVAL。}

Invaluable to all who take an interest in Naval Matters.

Published Annually.

\section{THE NAVAL POCKET BOOK.}

\section{Edited by Sir WM. LAIRD CLOWES.}

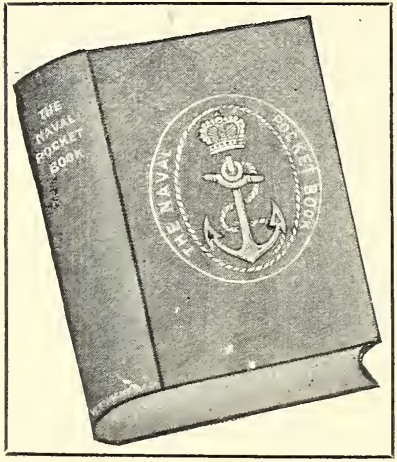

Lord Charles Beresford, in a letter, says:- "It is one of the most useful and handy works of reference on naval matters that I know of, and invaluable to all who take an interest in naval matters."

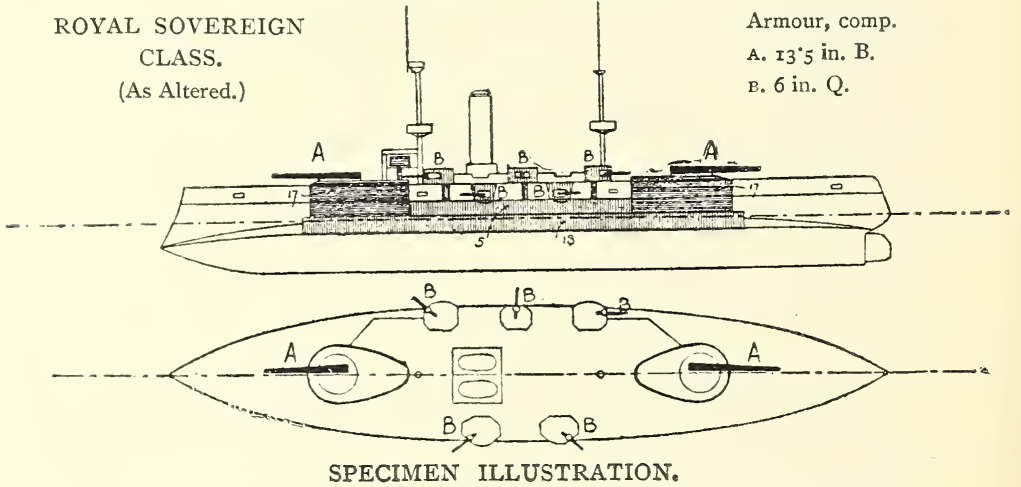

Pall Mall Gazette.-"The information contained upon the navies of the world is most complete and comprehensive, and the 900 pages of printed matter are remarkable for containing so much in so small a compass."

Naval and Military Record.- "A handy volume for use anywhere and everywhere. ..... Surprisingly accurate. 
Royal 8vo., cloth, 400 pages, 2Is. net. Rs. I8.6.

(UNiform With “The Imperial RUssian Navy.")

\section{THE IMPERIAL JAPANESE NAVY.} By FRED T. JANE,

Author of "All the World's Fighting Ships."

ITS HISTORY FROM THE EARLIEST TIMES TO THE PRESENT DAY.

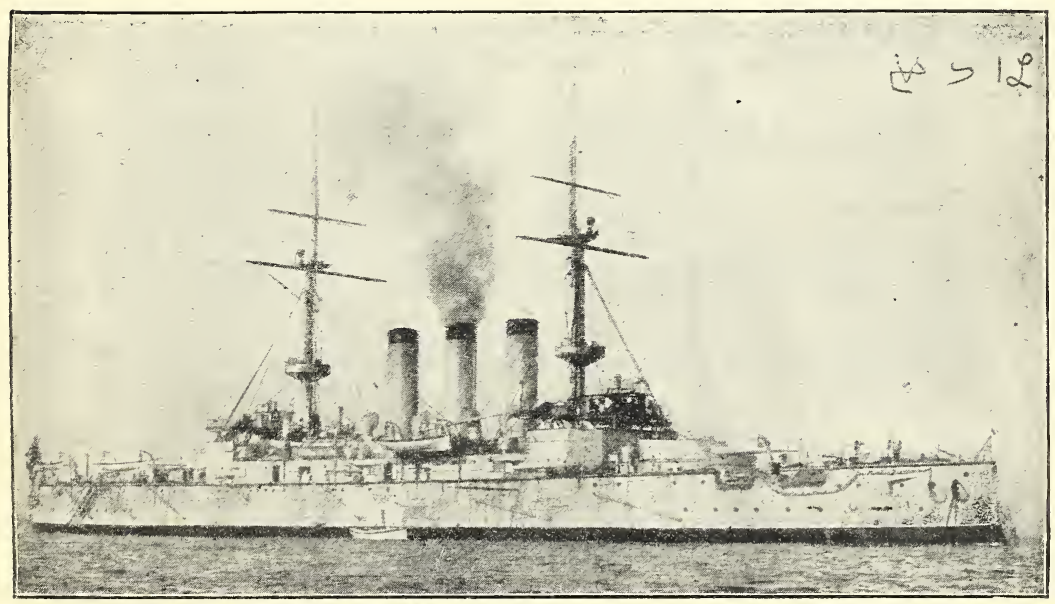

HATSUSE.

Plans, Photographs, and full descriptions of all Ships in the Japanese Navy, Dockyards, and Arsenals.

The China-Japanese War, with official reports and hitherto unpublished details, furnished in each case by officers who actually participated in the events described.

\section{The Far Eastern Problem-from the Japanese Standpoint.}

With over 80 Illustrations from Sketches and Drawings by Japanese Artists and from Photographs.

Naval and Military Record.- "This is a most excellent book, useful not alone as a handbook to the fleet, but as a complete guide to the whole of the sea service, and should prove of unmistakable value to professional men of any nationality."

The Spectator.- "Our readers had better study Mr. Jane's book, it is the best account extant of the Japanese Navy, and its possibilities as indicated by the Japanese officer."

nores The Morning Post. - "The work is in all other respects an excellent one and on a topic of world-wide importance; tersely written; splendidly illustrated by photographs and drawings." 
Royal 8vo., cloth, 730 pp., 25s. net. Rs. 22.

Uniform With "The Imperial Japanese Navy."

\section{THE IMPERIAL RUSSIAN NAVY. BY FRED T. JANE.}

With over 150 Illustrations from Sketches and Drawings by the Author and from Photographs.

The First Edition appeared 5 years ago. Since then the Russian Navy has, been revolutionised. The book has now been almost re-written, and stands as the only work dealing with the Russian Navy as it is in these early days of I904.

\section{Some of the Principal Contents.}

The Germ of the Russian Navy, 865-r645-Peter the Great's founding of the Russian Navy-Its Battles-Its History-Detailed Descriptions (with photographs and plans) of all the Ships at present on the Russian Navy List ; of all the Russian Dockyards-Russia's Shipbuilding Programme-Projected Ship. Canals-The Personnel of the Fleet-Anglo-Russian Relations-Biographies and Services of British Officers who have served in the Russian Navy-Plans of Battles-A Complete List of Russian War Ships, built and building.

The Times._- "Full of information compiled with laudable skill and industry, not the least instructive part of it being that which deals with the personnel of the Russian Navy, about which the average English reader knows, as a rule, little or nothing."

Daily Newes.-" Mr. Jane's volume of more than 700 pages may be described. as an up-to-date, well-arranged, and concise encyclopædia of its subject."

Oblong folio, cloth, $5^{\text {s. net. }} \quad$ Rs. 4.8 .

A NEW AND CHEAPER EDITION OF

\section{THE TORPEDO IN PEACE \& WAR. BY FRED T. JANE.}

With 30 full-page and numerous smaller Illustrations, the greater part of which are reproductions of actual sketches by the Author made at Sea on board Torpedo. Craft.

The book deals, as its title implies, with Torpedoes and Torpedo Craft generally, and should be in the hands-especially at the present time-of all who interest themselves in naval affairs.

Naval and Military Review.- "Altogether a handy and comprehensive work, and those interested in the subject will learn a good deal from it."

Marine Engineer.- "As a description of naval life as it is at this time we can cordially recommend it."

Large crown 8vo., cloth gilt, $3^{s .} 6 d$. Rs. 3 .

\section{BLAKE OF THE "RATTLESNAKE";}

\section{OR, THE MAN WHO SAVED ENGLAND.}

A most Thrilling Tale of Life on board a Torpedo Destroyer in time of War.

\section{By FRED T. JANE.}

With I6 Illustrations by the Author. 


\section{MILITARY.}

Third Edition. Nine Maps. Demy 8vo., cloth, ros. 6d. Rs. 9.

Revised and brought up to date by Major J. SHADWELL, P.S.C., late D.A.A.G. for Instruction.

\section{TACTICS AS APPLIED TO SCHEMES.}

\section{By Colonel J. SHERSTON.}

Especially suitable for Majors who wish to pass an Examination for Tactical Fitness to Command, and for Officers who wish to pass Promotion Examinations without attending a Garrison Class.

Second Edition. Six Maps. Demy 8vo., cloth, 6s. net. Rs. 4.8.

Much enlarged and brought up to date by Major L. I. SHADwell, P.S.C., late D.A.A.G. for Instruction.

\section{NORTH-WEST FRONTIER WARFARE.}

BEING A SUPPLEMENT TO "TACTICS AS APPLIED TO SCHEMES."

\section{By Colonel J. SHERSTON.}

Army and Navy Gazette.- "The treatment of this subject is most practical. ... Its author is an officer of great experience who knows exactly what are the essentials of the work."

Demy 8vo., cloth, 8s. $6 d$. net. Rs. 6.8.

\section{NOTES, QUESTIONS, AND ANSWERS ON MILITARY LAW.}

THE MANUAL OF MILITARY LAW AND INDIAN ARTICLES OF WAR SPECIALLY PREPARED FOR PROMOTION EXAMINATION.

\section{By Major L. J. SHADWELL, P.S.C., Suffolk Regiment,} late D.A.A.G. for Instruction.

Broad Arrow.- " We have before referred to the advantage of this system of instruction.... Both the questions and answers are written in a concise and easily-remembered form, which will be found of great assistance to the student." 
Demy 8vo., cloth, 9s. net. Rs. 7 .

\section{FORTIFICATION AS APPLIED TO \\ S C H E M E S.}

SPECIALLY PREPARED FOR PROMOTION

EXAMINATIONS.

\section{By Major L. J. SHADWELL, P.S.C., and} Major W. EWBANK R.E., D.A.A.G. for instruction.

Broad Arrow.- "This work is designed to assist officers in preparing for examinations, and, unlike many works we could name, it serves its purpose exactly. . . The authors are almost visibly present reading over the books with their pupils and explaining their difficulties. . . Particularly excellent is the way in which they thoroughly insisi upon the truth that fortification is the handmaid of tactics.

\section{Crown 8vo., cloth, $3^{\text {s. }}$ Rs. 2.4. \\ FORTIFICATION AND TOPOGRAPHY.}

MEMORANDA AND FORMULÆ.

By Lt.-Col. H. M. S. BRUNKER, P.S.C. Honours, Author of "Notes on Organisation and Equipment," etc.

These notes do not pretend to teach; it is intended they should be committed to memory while working up the text books and attending lectures. This will give a sure foundation on which to complete the study.

Broad Arrow. - "This is a useful contribution to the candidate's side of the struggle between examiner and examinee."

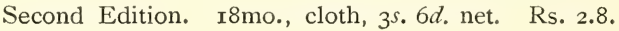

\section{THE ISSUE OF ORDERS IN THE FIELD.}

\section{By Capt. IVOR PHILLIPS, P.S.C.}

This book has been written to fill a want which must have been felt by those who have been suddenly called upon to write orders, either on active service or peace manœuvres, without any previous training and without any special book to turn to for assistance. 
Fcap. 8vo., cloth, 2s. 6d. net. Rs. 2.

\section{TRANSPORT OF HORSES BY SEA. By E. E. MARTIN, A.V.D.}

Hints for the Management and Treatment of Horses on Shipboard from actual experience gained on Active Service.

Fcap. 8vo., cloth, 2s. $6 d$. Rs. I.8.

\section{TRANSPORT.}

\section{By Major W. H. ALLEN}

(late Assistant Commissary General in India).

Pioneer.- "The work of condensation seems to have been admirably done, and the book is arranged on a plan which makes it a very simple matter to find the regulations relating to a particular subject."

Civil and Military Gazette.-"The transport officer and subordinate will possess a portable little vade-mecum with which to answer questions that constantly occur on outdoor duties . . . . it gives an abstract of the more important paragraphs contained in the Departmental Field Code relative to transport officers purchasing and equipping transport for the field."

Crown 8vo., cloth, 7s. $6 d$. net. Rs. 5 .

\section{THE FIGHTING RACES OF INDIA. BY P. D. BONARJEE}

(Assistant in the Military Department, Government of India).

An account of the Sikhs, Gurkhas, Pathans, Baluchis, Punjabis, Dogras, Rajputs, Mahrattas, and other tribes from whom the Indian Army is recruited. 


\section{HISTORY, CUSTOM, TRAVEL, \&C.}

Third Edition. With numerous Illustrations. Post 8vo., $7 s_{\bullet} 6 d$. Rs. 6.

\section{ECHOES FROM OLD CALCUT'TA.}

\section{CHIEFLY REMINISCENCES OF THE DAYS OF WARREN HASTINGS, FRANCIS, AND IMPEY.}

By H. E. BUSTEED, C.I.E.

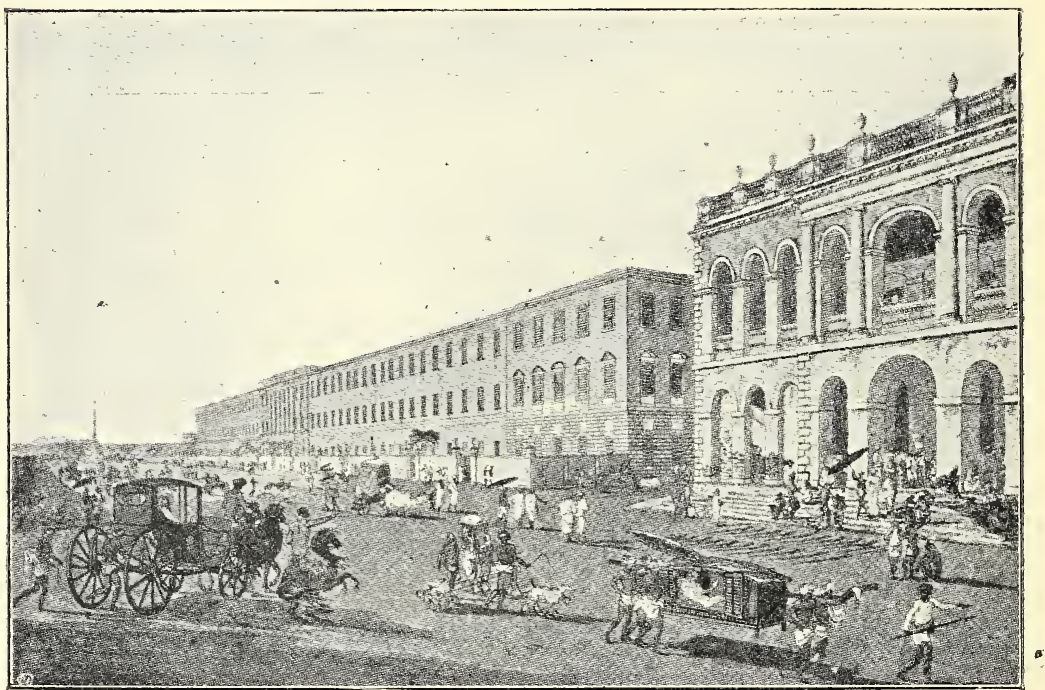

Daily Telegraph._-"Dr. Busteed has unearthed some astonishing revelations of what European Life in India resembled a century back."

Saturdav Review.- "It is a pleasure to reiterate the warm commendation of this instructive and lively volume which its appearance called forth some years since. It would be lamentable if a book so fraught with interest to all Englishmen should be restricted to Anglo-Indian circles. A fresh instalment of letters from Warren Hastings to his wife must be noted as extremely interesting, while the papers on Sir Philip Francis, Nuncomar, and the romantic career of Mrs. Grand, who became Princess Benevento and the wife of Talleyrand, ought by now to be widely known."

\section{Demy 8vo., paper, Is. 6d. net. Re. I. \\ THE SERAIMPORE PORTRAIT. \\ IS IT MADAME GRAND?}

By H. E. BUSTEED, C.I.E.

Being a Supplement to "Echoes from Old Calcutta." 
Demy 8vo., cloth, 334 pp., Ios. $6 d$. net. Rs. 6.

\section{THE EXPLORATION OF TIBET.}

ITS HISTORY AND PARTICULARS, FROM I623 To I904.

By GRAHAM SANDBERG, B.A.

\section{With Maps of Tibet and Plan of the Sacred City of Lhasa.}

Athencum.-" This is a timely and valuable record of the process of exploration by which Tibet has been gradually revealed to Western ken. . . . As a chronicle of travel and review of exploration, Mr. Sandberg's work merits praise for the cautious care and industry with which it has been compiled."

Two Vols. Demy 8vo., cloth, 24s. Rs. 18.

\section{THE HISTORY OF CHINA.}

BY DEMETRIUS C. BOULGER.

(Author of " Chinese Gordon," " Sir Stamford Raffles," etc., etc.)

Illustrated with Portraits and Maps.

The Second Volume contains a full History of China and her connection with European. Nations, and detailed accounts of all events, including the Chino-Japan War, and its Diplomatic consequences.

Saturday Review.- " One cannot read this admirable history without feeling how much Mr. Boulger's sympathies have been enlisted by the wonderful record of Chinese achievement and Chinese character which he has collected with so much charm and ability."

Pall Mall Gazette.- "Regarded as history pure and simple, Mr. Boulger's latest effort is all that such a work should be."

Demy 8vo., cloth, 400 pp., I6s. Rs. I2.

\section{THE CONGO STATE;}

OR, THE GROWTH OF CIVILIZATION IN CENTRAL AFRICA. BY DEMETRIUS C. BOULGER.

With 60 Illustrations and Map $(27 \times 25)$.

Times.- " On the whole an accurate and useful summary of the interesting enterprise of the King of the Belgians."

Bookman.-A very full and detailed history of the growth, development, and administration of the Congo."

Royal r2mo., cloth, 4s. 6 d. net. Rs. 3.8.

\section{A JAUNT IN JAPAN}

\section{OR, NINETY DAYS' LEAVE IN THE FAR EAST. \\ By Capt. S. C. F. JACKSON, D.S.O.}

Pioneer.- "To those in India who may be contemplating a trip to Japan, we can confidently recommend a little book by Capt. S. C. F. Jackson . . . . is very readable, and moreover it contains detailed information as to steamers, places en route, cost of travelling and living in Japan itself, what to se?, and what to avoid . . . Captain Jackson is a good guide." 
Ornamental cloth $($ Io $\times 7$ ), I8s. net. Rs. I2.

\section{SIMLA : PAST \& PRESENT. By E. J. BUCK.}

Dedicated to His Excellency Lord Curzon, G.M.S.I., G.C.I.E.

Being a complete account of the Origin, Early History, and Development of Simla, the Summer Residence of the Government of India, with descriptions of interesting Personages and their Residences, and an account of the Social Functions and Amusements of the Station.

Pioneer. - "Residents and Visitors will be both instructed and amused by the stories of social life in the old days, and the illustrations will add to their enjcyment of the letterpress. Nothing has been forgotten. It should be read by everyone."

Indian Daily Telegraph.- "The publication was first suggested to Mr. Buck by the Viceroy. It was a happy thought on the part of Lord Curzon, for it has been the means of giving to the literary public a well-written and informative volume."

Crown 8vo., cloth, 3 s. $6 d$. Rs. 2. Io.

\section{TALES FROM INDIAN HISTORY.}

\section{BEING THE ANNALS OF INDIA RE-TOLD IN NARRATIVES.}

\section{By J. TALBOYS WHEELER.}

Broad Arrow.- "The history of our great dependency made extremely attractive reading. Altogether, this work is of rare merit."

Daily Chronicle.- "Will absorb the attention of all who delight in thrilling records of adventure and daring. It is no mere complication, but an earnest and brightly written book."

Demy 8vo., cloth gilt, 7 s. 6 d. net. Rs. 6.

\section{SELECTED SPEECHES BY H.E. THE RIGHT HON. LORD CURZON, G.M.S.I., G.C.I.E., Viceroy and Governor-General of India. From 1898-1901.}

'l'his volume contains the principal speeches delivered by Lord Curzon from the date of his appointment as Viceroy up to the beginning of Igor. They deal with a great variety of subjects connected with the administration of India.

Royal 8vo, cloth.

\section{A SKETCH OF THE ETHNOLOGY OF INDIA.}

By H. H. RISLEY, I.C.S., C.S.I., C.I.E.

Officier of the French Academy, Corresponding Member of the Berlin Authropological Society and of the Authropological Institute of Great Britain and Ireland. 


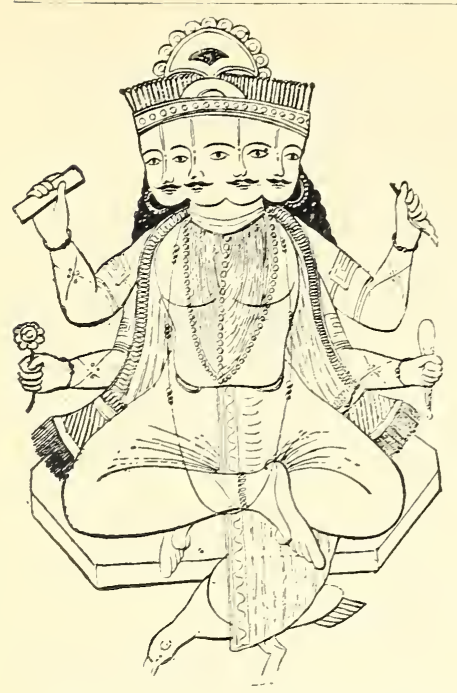

Second Edition. Revised. Crown 8vo., 75. 6d. Rs. 5.10.

\section{HINDU}

MYTHOLOGY :

VEDIC AND PURANIC.

\section{By Rev. W. J. WILKINS}

(late of the London Missionary Society, Calcutta).

Illustrated by Ioo Engravings, chiefly from Drawings by Native Artists.

Home News. - "The author has attempted a work of no little ambition and has. succeeded in his attempt, the volume being one of great interest and usefulness ; and not the less so because he has strictly refrained from diluting his facts with comments of his own. It has numerous illustrations."

Indian Daily News.- "In Mr. Wilkins' book we have an illustrated manual, the study of which will lay a solid foundation for more advanced knowledge, while it will furnish those who may have the desire without having the time or opportunity to go further into the subject, with a really extensive stock of accurate information.",

Second Edition. Revised. Crown 8vo, 7s. 6d. Rs. 5. Io.

\section{MODERN HINDUISM.}

AN ACCOUNT OF THE RELIGION AND LIFE OF THE HINDUS IN NORTHERN INDIA.

\section{By Rev. W. J. WILKINS.}

\section{Contents.}

LIFE AND WORSHIP - MORALS - WOMAN-CASTE - SECTS - DEATH SHRADHA-FUTURE LIFE.

Saturday Review._- "He writes with a liberal and comprehensive spirit." 
Crown 8vo., cloth, I6s. net. Rs. I2.

\section{HINDU CASTES AND SECTS.}

An Exposition of the Origin of the Hindu Caste System and the bearing of the Sects towards each other and towards other Religious Systems.

\section{By Pandit JOGENDRA NATH BHATTACHARYA, M.A., D.L.}

Madras Mail. - "A valuable work. . . . The Author has the courage of his convictions."

Second Edition. Crown 8vo., cloth, 7s. 6d. net. Rs. 5 .

\section{THE HINDOOS AS THEY ARE.}

A DESCRIPTION OF THE MANNERS, CUSTOMS, AND INNER LIFE OF HINDOO SOCIETY, BENGAL.

\section{By SHIB CHUNDER BOSE.}

Westminster Gazette.- "Shib Chunder Bose is an enlightened Bengali of matured conviction and character, and his extended and varied experience eminently qualify him for lifting the veil from the inner life of his countrymen.'

Crown 8vo., cloth gilt, $3 s .6 d$. net. Rs. 2.8 .

\section{THE ETHICS OF ISLAM.}

\section{A LECTURE BY}

\section{The Hon'ble AMEER ALI, C.I.E.}

(Author of " The Spirit of Islâm," "The Personal Law of the Mahomedans," etc.)

An attempt towards the exposition of Islâmic Ethics in the English language. Besides most of the Koranic ordinances, a number of the precepts and sayings of the Prophet, the Caliph Ali, and "Our Lady" are translated and given.

Second Edition. 8vo., cloth, 7s. 6d. net. Rs. 6.9.

\section{REPRESENTATIVE INDIANS. By G. P. PILLAI, B.A. \\ Forty Biographies, with Portraits.}

Short Biographies of the best representatives of the new type of men who have been brought into existence in India since the growth of British power in that land. Statesmen: philanthropists: jurists: educationists: archæologists: scholars : religious, social, and political reformers : journalists, and those who have promoted industries. 
Second Edition Crown 8vo., 6s. net. Rs. 4.8.

\section{COW KEEPING IN INDIA.}

\section{By ISA TWEED.}

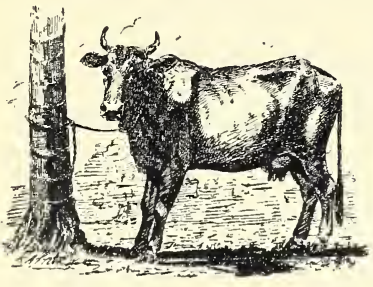

A Simple and Practical Book on their Care and Treatment, their various Breeds, and the means of rendering them profitable.

With 39 Illustrations of the various Breeds of Cattle, drawn from Photographs by R. A. STERNDALE.

Home News. - "By the aid of this volume anyone of ordinary intelligence and industry could keep cows certainly with advantage, possibly even with profit to themselves.'

Madras Mail. - "A most useful contribution to a very important subject, and we can strongly recommend it."

Second Edition. Crown 8vo., boards. Rs. 2.

\section{COWS IN INDIA AND POULTRY.}

\section{THEIR CARE AND MANAGEMENT.}

\section{By Mrs, JAMES.}

Civil and Military Gazette- "A simple and practical book, the result of personal observation and experience."

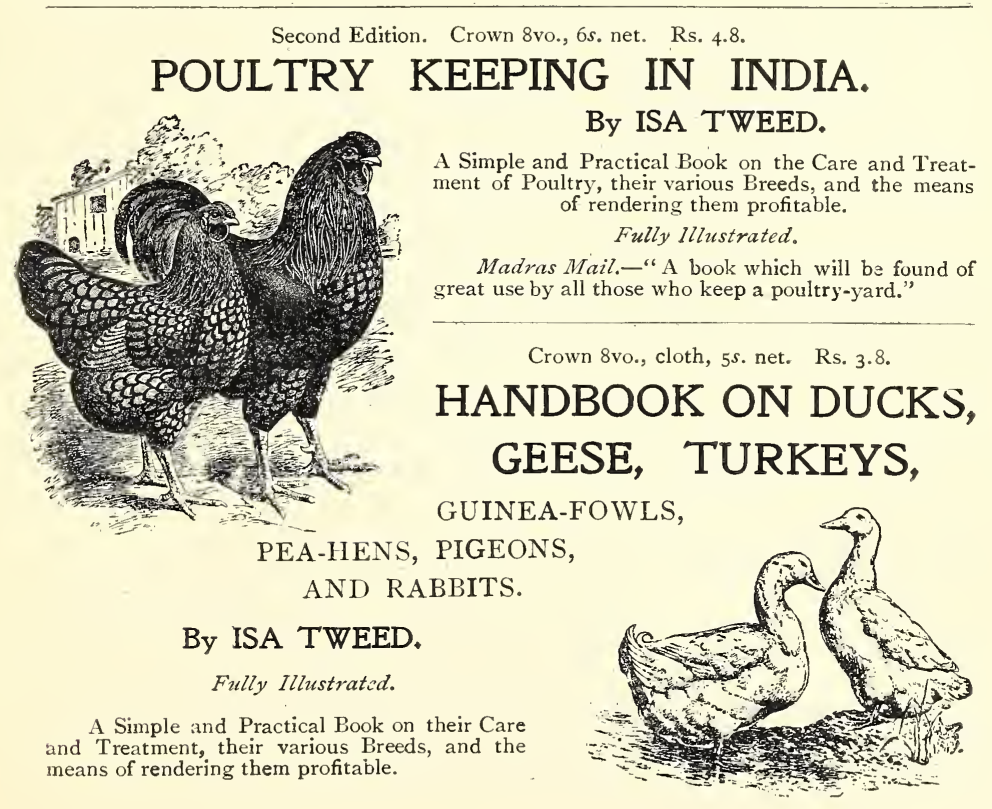


Crown 8vo., cloth, 4 s. $6 d$. net. Rs. 3 .

\section{THE INDIAN COOKERY BOOK.}

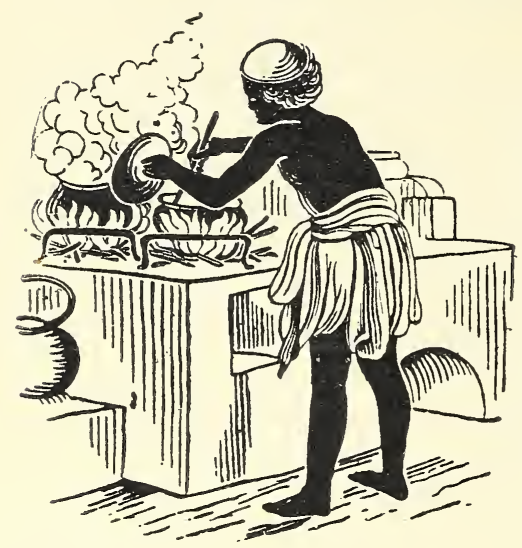

\section{By a Thirty Years' Resident.}

A PRACTICAL HANDBOOK TO THE KITCHEN IN INDIA, ADAPTED. TO THE

THREE PRESIDENCIES.

Containing original and Approved Recipes in every Departnent of Indian Cookery-Recipes for Summer Beverages and Home-made Liqueurs - Medicinal and other Recipes, together with a variety of things worth knowing.

Pioneer. - "The oldest but still the best cookery book."

Second Edition. Crown 8vo., boards, 3s. 6d. net. Rs. 2.8.

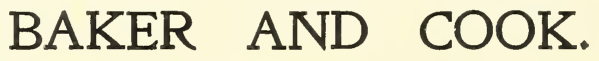

A DOMESTIC MANUAL FOR INDIA.

By Mrs. R. TEMPLE WRIGHT.

Pioneer. - "The outcome of long experience and many patient experiments."

Englishman.- "No better authority on matters relating to the Kitchen and all that pertains to cuisine is to be found than Mrs. Temple-Wright."

Crown 8vo., paper boards, 3s. net. Rs. 2.

\section{"WHAT" AND " $\mathrm{HOW}$ ", \\ OR,}

WHAT SHALL WE HAVE? AND

HOW SHALL WE HAVE IT?

\section{By Miss E. S. POYNTER.}

This book does not aim at being an Instructor in the Art of Cookery. It has. been written to meet a long felt need, a cheap handbook, giving a variety of dishes made of materials readily obtained in any part of India. 
Third Edition. Crown 8vo., cloth, 600 pages, 7s. 6d. net. Rs. 6.

\section{THE MEIMSAHIB'S \\ BOOK OF COOKERY. \\ By CARRIE CUTCREWE.}

Times of India.- "It contains much useful information and cannot fail to be of assistance to all.'

I8mo., cloth, 3 s. net. Rs. 2 .

\section{THE IMEIMSAHIB'S}

\section{BOOK OF CAKES, BISCUITS, \&c.}

WITH REMARKS ON OVENS, A HINDUSTANI

VOCABULARY, WEIGHTS AND MEASURES, \&c.

By CARRIE CUTCREWE.

Crown 8vo., paper boards, $4 s$. net. Rs. 3 .

\section{SIMPLE MENUS AND RECIPES.}

FOR CAMP, HOME, AND NURSERY.

\section{BY LUCY CARNE.}

Containing Menus and Recipes for Meals in Camp-Afternoon Teas-Station

Dinners-Meals for Children, and many useful Hints for Housewives in India.

Long I2mo. paper boards, 3 s. net. Rs. 2.

\section{EVERYDAY MENUS FOR INDIA.}

By W. S. BURKE, Editor "Indian Field."

These Everyday Menus are such as any average Native Cook can undertake, and have been selected with special regard to the moderate purse.

Contents.

Every Day Menus: March to June, July to October, November to FebruaryKitchen Calendar-Hot and Cold Weather Dinners-Special Breakfasts Recipes. 


\section{BOTANIC.}

Fifth Edition. Imperial 16 mo., cloth, 700 pages, I5s, net. Rs. Io.

\section{A MANUAL \\ FOR BENGAL, UPPER AND SOUTHERN INDIA. By Rev. T. A. C. FIRMINGER, M.A. With Portrait and Biography.}

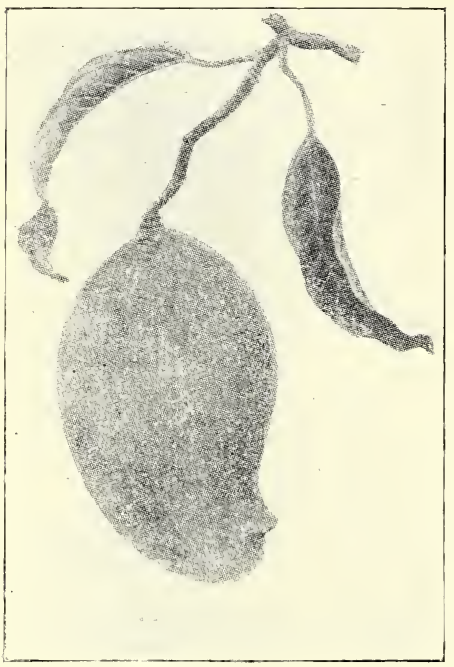

Thoroughly revised and brought up to date by J. Cameron, F.L.S., Supt. Mysore Government Gardens, Bangalore.

\section{CONTENTS :}

PART I.

Gardening Operations.

Chap. I. Climate-Soil-Manures.

Chap. II. Laying Out a Garden-Lawns - Hedges-Hoeing and DiggingIrrigation - Drainage - Conservatories-Betel Houses-DecorationsImplements - Shades - Labels Vermin-Weeds.

Chap. III. Seeds - Seed Sowing - Pot Culture-Planting and Transplanting - Cuttings-Layers - Gootee-Grafting and Arching-Budding-Pruning and Root-Pruning - Conveyance Calendar of Operations.

PART II.

The Vegetable Garden. PART III.

The Fruit Garden and Fernery. PART IV.

The Flower Garden-Index.

Indian Field.- "From beginning to end this revision of the Fifth Edition of an old popular-work which past generations have regarded as a vade mecum, teems with the minutest instructions, all being brought up to date by the reviser, who must have devoted an enormous amount of time, labour and observation to the compilation. ... Freely embellished with woodcuts, the work forms a regular epitome for the student, while to those of experience the copious index in which the botanical, common and native names of the plants are given, will prove of service as a ready reference.

Second Edition. Crown 8vo., cloth, $3^{s .6 d}$. net. Rs. 2.8.

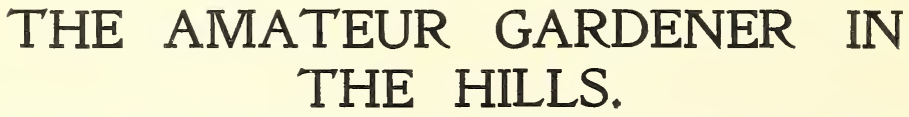

Hints from various authorities on Garden Management adapted to the Hills; also a few Hints on Fowls, Pigeons, and Rabbits, and various Recipes connected with the above subjects which are not commonly found in recipe books.

\section{By AN AMATEUR.}


Fourth Edition. Post 8vo., boards, 3s. $6 d$. net. Rs. 2.8.

\section{FLOWERS AND GARDENS IN INDIA.}

\section{A MANUAL FOR BEGINNERS. \\ By Mrs. R. TEMPLE WRIGHT.}

Civil and Military Gazette.- "A most useful little book which we cannot too strongly recommend. We can recommend it to our readers with the utmost confidence, as being not only instructive, but extremely interesting, and written in a delightfully easy, chatty strain."

Pioneer. - "Very practical throughout. There could not be better advice than this, and the way it is given shows the enthusiasm of Mrs. Temple Wright."

Imperial I6mo., cloth, I2s. $6 d$. Rs. 9.6.

\section{A HANDBOOK TO}

THE FERNS OF INDIA, CEYLON, AND THE MALAY PENINSULA.

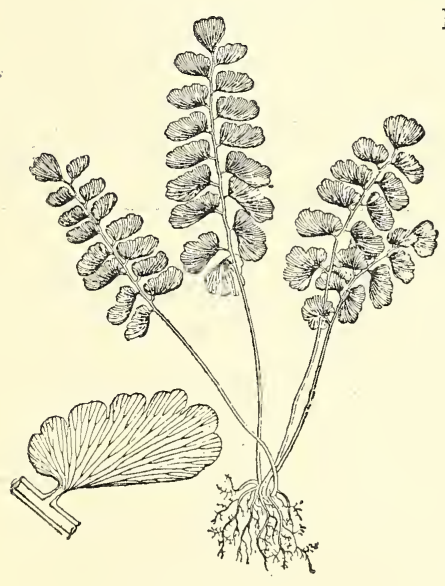

By Colonel R. H. BEDDOME, F.S.I. (late Conservator of Forests, Madras).

\section{With 300 Illustrations.}

Nature.- "It is the first special book of portable size and moderate price which has been devoted to Indian Ferns, and is in every way deserving of the extensive circulation it is sure to obtain.

Indian Daily News.- "I have just seen a new work on Indian Ferns which will prove vastly interesting, not only to the Indian people, but to the botanist of this country."

Gardeners' Chronicle._-"The 'Ferns of India.' This is a good book, being of a useful and trustworthy character. The species are familiarly described, and most of them illustrated by small figures."

Free Press. - "Those interested in botany will do well to procure a new work on the 'Ferns of British India.' The work wili prove a first-class text-book."

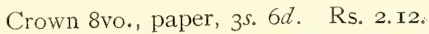

\section{SUPPLEMENT TO THE \\ FERNS OF INDIA, CEYLON, \&c.}

By Colonel R. BEDDOME, F.I.S.

Containing Ferns which have been discovered since the publication of "A Handbook to the Ferns of British India 
Demy 8vo., cloth gilt, 700 pages, I5s. net. Rs. Io.

\section{FLORA SIMLENSIS.}

A HANDBOOK OF THE FLOWERING PLANTS OF SIMLA AND NEIGHBOURHOOD.

By the late Col. Sir HENRY COLLETT, K.C.B., F.L.S., Bengal Army.

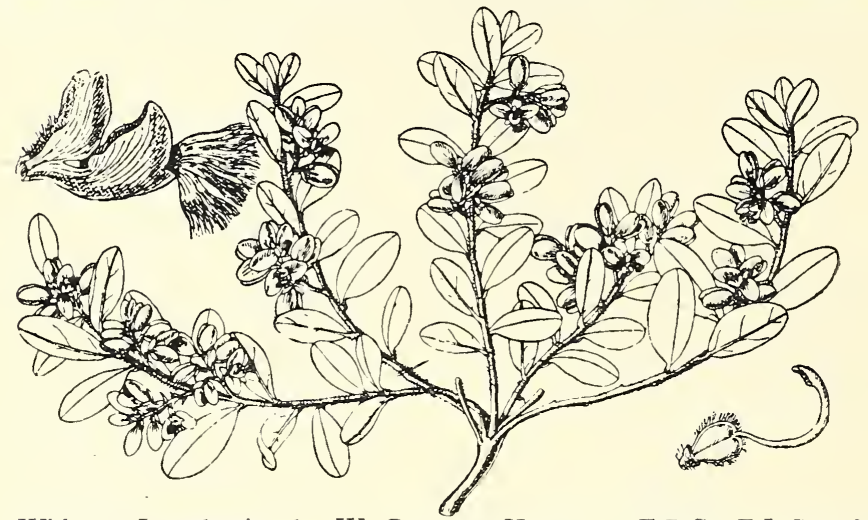

With an Introduction by W. BotTing Hemsley, F.R.S., F.L.S., of the Royal Gardens, Kew ; and 200 Illustrations in the text drawn by Miss M. SMith, Artist at the Herbarium, Kew Gardens ; and a Map.

\section{Royal 8vo., cloth, 800 pages, 7s. $6 d$. net. Rs. 5 . \\ ROXBURGH'S FLORA INDICA.}

By the late W. ROXBURGH, M.D., F.R.S.E., \&c:

BEING A COMPLETE DESCRIPTION OF INDIAN PLANTS.

Reprinted literatim from Cary's Edition of 1832, and being the only complete handbook of Indian Plants obtainable.

\section{Crown 8vo, boards, 3s. 6d. net. Rs. 3 . \\ FOOD FOR THE TROPICS.}

BEING A SHORT DESCRIPTION OF NATIVE PRODUCE

SUITABLE FOR FOOD IN TROPICAL CLIMATES.

By T. M. MACKNIGHT.

Lancet.- "This is a valuable book, and, as Mr. Macknight implies in his preface, fills a gap. ... The book is a useful addition to the cuisine of a house. hold in the tropics."

Canada Lancet.- "This is a most useful and instructive little work."

Food and Cookery.- "The work contains a fairly full description of native produce suitable for food in tropical climates, which should prove of great value to. students of cookery and others who may be interested in these foods." 


\section{ECONOMIC.}

Demy 8vo., cloth, 300 pp., 7s. 6d. net. Rs. 6.

\section{INDIAN TEA :}

\section{ITS CULTURE AND MANUFACTURE. \\ Being a Text-Book on the Cultivation and Manufacture of Tea. By CLAUD BALD (of Lebong Tea Company, Ltd.)}

Illustrated from Photographs and Drawings.

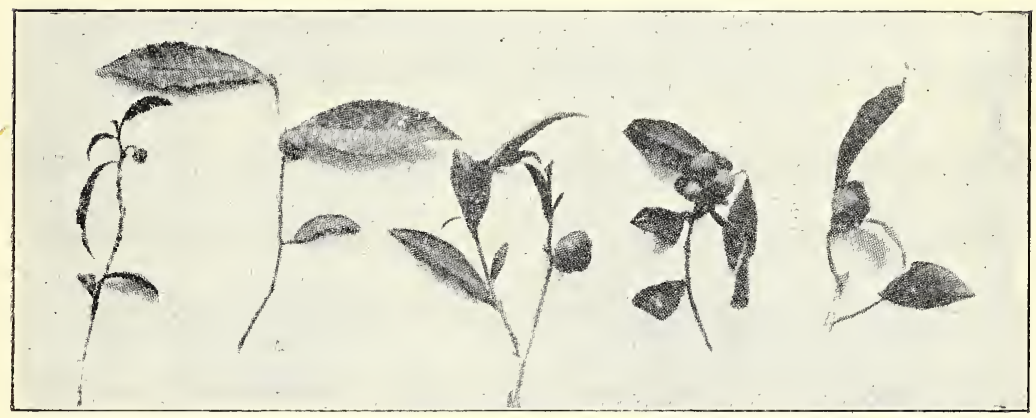

SPECIMEN ILLUSTRATION.

CONTENTS, -Cultivation-Drainage-Pruning-Extension-Tea Seed-Preparation of Land and Planting-Roads-Landslips-Manuring-Renovation of Deteriorated Areas-Blights-Forestry-Manufacture-Plucking-Withering -Rolling-Fermentation-Firing or Drying-Sifting and Sorting-PackingQuality - Green Tea-Buildings - Machinery-Railways and TramwaysAccounts-The Cooly-Appendix.

Madras Mail._- "As a record of the experience of a successful planter it is sure of a wide circle of readers."

Englishman.- "It is fitted to become from the date of publication the book upon tea cultivation and manufacture."

Extract of Letter from a leading firm in Calcutta.-We have found it very interesting, and have ordered several copies for the use of our various assistants; and it only requires to become better known to be more widely circulated."

\section{Crown 8vo., cloth, 5s, net. Rs. 4 .}

\section{ON INDIGO MANUFACTURE.}

A Practical and Theoretical Guide to the Production of the Dye, with numerous Illustrative Experiments.

\section{By J. BRIDGES LEE, M.A., F.G.S.}

Pioneer.- "Instructive and useful alike to planter and proprietor. . . . . A very clear and undoubtedly valuable treatise for the use of practical planters." 


\section{MEDICAL \& MATERIA MEDICA.}

Complete in One Volume. Royal 8vo., cloth, 720 pages, 25s. net. 'Rs. I8.

\section{MEDICAL JURISPRUDENCE FOR INDIA.}

\section{By I. B. LYON, C.I.E., F.C.S., F.I.C., Brigade Surgeon}

(late Professor of Medical Jurisprudence, Grant Medical College, Bombay).

New Edition. Thoroughly revised, and brought up-to-date by Lieut.-Col. L. A. WADDELL, M.B., C.I.E., LL.D., F.L.S.

With Numerous Illustrations.

Contents-Part I.

Identification of the Living and Dead - Examination of Living Persons Examination of the Dead-Examination of Blood, \&c.

Part II.

Kinds of Violent Death-Wounds, Blows, \&c. - Asphyxial Deaths - Burns and

Scalds-Death from Extremes of Temperature, \&c.-Death from Starvation-

Sexual Defects-Rape and Unnatural Sexual Offences-Pregnancy-Birth in

Relation to Civil Law (Legitimacy and Inheritance)-Fœeticide or Criminal

Abortion-Infanticide-Medical Responsibility and Malpraxis.

Lancet. - "The work forms a trustworthy guide to the subjects of which it treats... the new edition will be found on examination to merit fully the favourable review which it received on its first appearance."

Fourth Edition, Revised. Being the Tenth Edition of "Goodeve's Hints for the Management of Children in India."

Crown 8vo., cloth, Ios. 6d. Rs. 7.14.

\section{HINTS FOR THE MANAGEMENT AND MEDICAL TREATIMENT OF CHILDREN IN INDIA.}

\section{By EDWARD A. BIRCH, M.D.}

(late Principal, Medical College, Calcutta).

The Medical Times and Gazette, in an article upon this work and Moore's "Family Medicine for India," says: "The two works before us are in themselves probably about the best examples of medical works written for non-professional readers. The style of each is simple, and as free as possible from technical expressions."

Pioneer.- "It is a book which ought to be found in every household."

Indian Medical Gazétte. - "It has become more and more valuable and useful as well to the anxious mother in India as to the practitioner." 
Fcap. 8vo., with diagrams, cloth, 3 s. $6 d$. Rs. 2. Io.

\section{MEDICAL HINTS FOR HOT CLIMATES.}

AND FOR THOSE OUT OF REACH OF PROFESSIONAL AID.

By CHARLES HEATON, M.R.C.S.

Hospital Gazette. - "We can recommend this book to those who are in the Colonies as a useful, handy guide to health.'

I6mo., cloth, is, 6d, net. Re. I.

\section{PRACTICAL HINTS ON THE PRESERVATION OF HEALTH IN INDIA.}

By L'eut.-Col. G. S. A. RANKING, M.O., M.R.C.S., I.M.S.

Pioneer._- "Most useful and practical."

Madras Mail._- "Ranking's Practical Hints will come as a boon ; and there is much in the book which should be read by all,"

Second Edition, with Illustrations. Crown 8vo., cloth, 6s. Rs. 4.8.

\section{THE CARLSBAD TREATIMENT FOR TROPICAL AND DIGESTIVE AILMENTS AND HOW TO CARRY IT OUT ANYWHERE. \\ By LOUIS TARLETON YOUNG, M.D.}

Irish Times.-- "The book is of a most useful nature, and inspires confidence by the candour and fulness of its information and points of guidance."

Home News.- " The book contains the result of six years' practical experience, and should be of as much advantage to medical men as to sufferers."

Crown 8vo., cloth, 7 s. $6 d$. net. Rs. 5 .

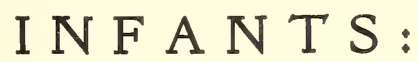

THEIR AILMENTS AND MANAGEMENT IN INDIA.

By Major D. SIMPSON, I.M.S.

Indian Medical Gazette.-."Will be read with interest by inedical men, though mainly intended for mothers."

Indian Medical Gazette.- "We recommend it to our readers who would do no harm by reading it themselves and much good by recommending it to their patients."

Colonel Blandford, I.M.S. (Retired).--"An excellent and useful guide to mothers and those in charge of infants. . . . Not only is it a sound work, but the advice is put in such a readable form that it appeals directly to the mother." 
Second Edition. Demy 8vo., cloth, Ios. 6d. net. Rs. 6.

\section{THE INDIGENOUS DRUGS OF INDIA}

SHORT DESCRIPTIVE NOTICES OF THE PRINCIPAL MEDICINAL PRODUCTS MET WITH IN BRITISH INDIA.

\section{By RAI BAHADUR KANNY LALL DEY, C.I.E.}

Indian Daily News.- "It shows an immense amount of careful work upon the part of the compilers ... and will be useful to students and to that very large class of people who are interested in developing the resources of the country . . . above all, the work contains a really good index of 4,ooo references, and a complete glossary to the vernacular names."

Englishman.- "His work is a compendium of forty years' experience, and deserves to be widely popular and carefully studied."

Pharmaceutical Journal. - "A work on Indian drugs which is thoroughly up to date, and as reliable as any book can be made, even with the help of experts."

Demy 8vo., cloth, 8s. 6d. net. Rs. 6.

\section{MATERIA MEDICA FOR INDIA.}

Giving the Official Drugs and Preparations according to the British Pharmacopœia of 1898 , with details of over 300 of the most important Indian Drugs, and practical statemeats of their Pharmacology, Therapeutics, and Pharmacy.

By C. F. PONDER, M.B., \& D. HOOPER, F.C.S., F.L.S.

Journal of Tropicai Medicine._"We commend this book to Students of Medicine in India. It is carefully and accurately written, and the descriptions of the properties of drugs can be readily followed and understood."

Third Edition. Fcap. 8vo., cloth. Re. I.8.

\section{BANTING IN INDIA.}

WITH SOME REMARKS ON DIET AND THINGS IN GENERAL. By Surgn.-Lieut.-Col. JOSHUA DUKE.

Crown 8vo., paper boards. Rs. 2.

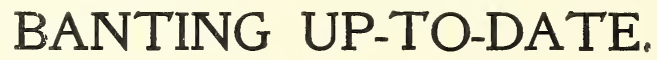

By the Author of "A Bobbery Pack in India."

Pioneer.- " It may be heartily commended to all who really want to improve health and figure alike by getting rid of what our doctors call 'superfluous adipose deposit ' and our horrid friends call 'fat.' "' 
Quarto (II $\times 8$ ), cloth, 24s. net. Rs. I6.

\section{A MONOGRAPH OF}

\section{THE ANOPHELES MOSQUITOES OF INDIA.}

By Capt. S. P. JAMES, M.B. (Lond.), and Capt. W. GLEN LISTON, I.M.S.

With 15 Full-page Coloured Plates, 67 Illustrations in Half-Tone (on 15 Plates), a Map, and 30 Diagrams and Illustrations in the Text.

\section{Contents :}

PArt I.-General: A General account of Mosquitoes-The Collection, Mounting, Examination, and Identification of "Anopheles" Mosquitoes and their Larvæ.

-The Habits of Indian "Anopheles "-The Classification of "Anopheles."

Part II.-Systematic: Giving a Detailed Description of the Ten different Groups of "Anopheles" Mosquitoes.

Indian Medical Gazette._-"Will be of the greatest value and interest to all who are working at the subject of Mosquito Malaria .. . . the most valuable monograph we have yet seen on the mosquitoes of India.

Second Edition. Demy 8vo., cloth, 7s. $6 d$. net. Rs. 6.

\section{MALARIAL FEVER}

\section{AND MALARIAL PARASITES \\ IN INDIA.}

By Major ANDREW BUCHANAN, I.M.S., M.D.

(Offg. Civil Surgeon, Nagpur, C. India).

Profusely Illustrated with Coloured Plates and Charts.

Indian Medical Gazette.- "It is a book that should be introduced into every Medical College in India, and it is of especial value as being the work of an observer in India contending with the same difficulties as any other worker in India.

I 2mo. boards. Re. I.

\section{AN ELEMENTARY MANUAL OF MIDWIFERY.}

FOR THE USE OF INDIAN MIDWIVES IN RECEIPT

OF SCHOLARSHIPS FROM THE VICTORIA

MEMORIAL SCHOLARSHIP FUND.

By C. P. LUKIS, M.B., F.R.C.S., Lt.-Col., I.M.S.

(Principal, Agra Medical School.) 


\section{LANGUAGES.}

Fourth Edition. Crown 8vo., cloth, 7s. $6 d$. net. Rs. 6.

A GUIDE TO HINDUSTANI.

Specially designed for the use of Officers and Men serving in India. Containing Colloquial Sentences in Persian and Roman Character, and in English; also a Series of Arzis in Urdu written character with their transliteration in Roman-Urdu, and English translations. By GEo. S. Ranking, B.A., M.D., Lieut.-Col. I.M.S., Secretary to the Board of Examiners, Fort William.

Athenceum.-_" Lieut. -Col. Ranking has undoubtedly rendered good service to. the many military men for whom knowledge of Hindustani is essential."

\section{Crown 8vo., cloth, 6s. 6 . net. Rs. 5 .}

\section{INTRODUCTORY EXERCISES IN URDU PROSE COMPOSITION.}

A Collection of 50 Exercises with Idiomatic Phrases and Grammatical Notes, accompanied by a full. Vocabulary and Translation of each passage. By G. S. A. Ranking, B.A., M.D., Lieut.-Col. I.M.S.

Indian Daily News. - "One of the best works on the Urdu language that we have yet seen. . . . . the student will find in Dr. Ranking's work a really valuable aid. . . . ."

\section{Small 4to., boards, $6 s$. net. Rs. 6.}

\section{SPECIMEN PAPERS (English and Vernacular).}

For the Lower and Higher Standard Examinations in Hindustani, together with a Résumé of the Regulation for these Examinations for the Guidance of Candidates. Compiled by G. S. A. Ranking, B.A., M.D., Lieut.-Col. I.M.S.

\section{I6mo., cloth, $3^{\text {s. net. Rs. } 2 .}$}

\section{A POCKET BOOK OF COLLOQUIAL HINDU- STANI.}

By G. S. A. Ranking, B.A., M.D., Lieut.-Col. I.M.S.

In two parts, each 6s. net. Rs. 4.

\section{ANNOTATED GLOSSARY TO THE BAGH-O- BAHAR.}

By Lieut.-Col. Ranking, M.D., I.M.S. Containing a full glossary of the words, page by page, in the Hindustani and Roman Characters, forming a complete Lexicon to the book. With full Grammatical and Explanatory Notes. PART I.-The portion prescribed for the Lower Standard. PART II.-The additional portions prescribed for the Higher Standard.

Third Edition. Revised. Crown 8vo., cloth, 6s. net. Rs. 4.8. HINDUSTANI AS IT OUGHT TO BE SPOKEN. By J. Tweedie, Bengal Civil Service.

Supplement, containing Key to the Exercises and Translation of the Reader, with Notes, 2s. $6 d$. net. Rs. 2.

Indian Daily Nerws. - "The young civilian or officer, reading for his examination, could not do better than master this Revised Edition from cover to cover." 
Royal 8vo., cloth, $7 s .6 d$. net. Rs. 6.8 .

\section{URDU READER FOR BEGINNERS.}

By Major F. Chapman, Royal Military College, Camberley. Containing Classified Lists of useful words with transliteration in Roman Urdu ; Elementary Grammatical Exercises with transliteration; Easy Selections from various authors; Selections from Indian History; Selections from the "Bagh-o-Bahar"; together with a complete Vocabulary.

\section{Crown 8vo., cloth limp, 6s. Rs. 5 .}

\section{GRAMMAR OF THE URDU OR HINDUSTANI LANGUAGE IN ITS ROMANIZED CHAR- ACTER.}

By Rev. George Small, M.A.

Indian Churchman.- "We recommend it to those who wish to gain a more scientific knowledge of Urdu than the ordinary primers afford."

\section{Crown 8vo., cloth limp, 6s. Rs. 5 . \\ ANGLO-URDU MEDICAL HANDBOOK.}

Or Hindustani Guide. For the use of Medical Practitioners (male and female) in Northern India. By Rev. George Small, M.A. With the aid of Surgeon-General C. R. Francis, M.B., and of Mrs. Fraser Nash, L.R.C.P.

Home Nerus. - "This handbook should prove invaluable for use in schools and colleges where surgeons, missionaries, and nurses are being trained for work in the East.'

\section{COMMERCIAL HINDUSTANI.}

Second Edition. Crown 8vo., cloth. Rs. 2.8.

A Collection of Practical Phrases and a Vocabulary of Useful Terms in every-day use in business circles. English and Hindustani. By Munshi Jwala Nath Pandit.

\section{Second Edition. 4to., cloth. Rs. 6.}

\section{A HANDBOOK TO THE KAITHI CHARACTER.}

By G. A. Grierson, C.I.E., I.C.S., Ph.D., of H.M. Indian Civil

Service. With Lithograph Facsimilies, Transliteration and Translation.

\section{PUSHTO GRAMIMAR.}

Second Edition. Crown 8vo., cloth, 8s. $6 d$. Rs. 6.

By Gen. Sir J. L. VAughan.

\section{Crown 8vo., cloth, 9s. Rs. 6.I2.}

\section{THE RUSSIAN CONVERSATION GRAMMAR.}

By Alex. KInloch, late Interpreter to H.B.M. Consulate and British Consul in the Russian Law Courts; Instructor for Official Examinations.

With Key to the Exercises.

This work is constructed on the excellent system of Otto in his "German Conversation Grammar," with illustrations accompanying every rule, in the form of usual phrases and idioms, thus leading the student by easy but rapid gradations to a colloquial attainment of the language. 


\section{GUIDE BOOKS.}

AGRA, DELHI, ALLAHABAD, CAWNPORE, LUCKNOW, AND BENARES. By H. G. KeENE, C.S. With Maps and Plans. In one Fcap. 8vo. volume, 7s. 6d. net. Rs. 5.

AGRA.-HANDBOOK TO AGRA AND ITS NEIGHBOURHOOD. By H. G. KeENE, C.S. Sixth Edition, Revised, Maps, Plans, \&c. Fcap. 8vo., cloth, $3 s$. $6 d$. net. Rs. 2.8 .

ALLAHABAD, LUCKNOW, CAWNPORE, AND BENARES. By A. G. KeEne, C.S. Second Edition. Revised. With 4 Maps and a Plan. Fcap. 8vo., cloth, $3 s .6 d$. net. Rs. 2.8.

CACHAR AND SYLHET, ROUTES TO. A Map Revised and Corrected from the Sheets of the Indian Atlas, 4 miles $=I$ inch. Showing Rail, Road, and Steamer Routes, Tea Gardens, \&c. With a Handbook. By James PeTer. Four Sheets, folded in case, Rs. 3. Mounted on linen, in one Sheet, folded in cloth case, book form, Rs. 6. Mounted on linen and rollers, varnished, Rs. 9.

CALCUT'TA.-GUIDE TO CALCUT'TA. By Edmund Mitchell. Fcap. 8vo., sewed, Is. 6i. net. Re. I.

CALCUTTA ILLUSTRATED. A Series of Photo Reproductions of upwards of 30 Views of the City, including the Government Offices, Public Buildings, Gardens, Native Temples, Views on the Hooghly, and other Places of Interest, with descriptive Letterpress. Oblong 4to., paper, 6s. net. ; Rs. 4 ; cloth, $7 s .6 d$. net. ; Rs. 5 .

CALCUTTA ROYAL BOTANIC GARDEN, A GUIDE TO THE. By Sir George King, M.B., LL.D., C.I.E., F.R.S. With a Map. 8vo., sewed, Is. net. As. 8.

DARJEELING. - GUIDE TO DARJEELING AND ITS NEIGHBOURHOOD. By EDMUND Mitchell M.A. Second Edition. By G. Hutton TAYloR. With I3 Illustrations and three Maps. Fcap. 8vo., sewed, 3s. net. Rs. 2.

DELHI.-HANDBOOK TO DELHI AND ITS NEIGHBOURHOOD. By H. G. KeEne, C.S. Fifth Edition. Fcap. 8vo., cloth, $3 s .6 d$. net. Rs. 2.8.

INDIA.-GUIDE TO INDIA AND INDIAN HOTELS. By G. HUTTON TAYLOR. With 90 Half-tone Illustrations of celebrated places from Photographs. Coloured Map of India. Crown 8vo., stiff wrapper, Is. $6 d$. net. Rs. 2.

KASHMIR, A TRIP TO. By JAmes ARbUthnot. With 64 Illustrations. Crown 4to., cloth, gilt, IOs. $6 d$. net. Rs. 8. 
KASHMIR AND JAMMO.-A GUIDE FOR VISITORS TO KASHMIR AND JAMMO. By Lieut-Col, Duke, I.M.S. Second Edition. Being the Sixth Edition of Ince's Handbook, enlarged and brought up to date. With Map of Kashmir and Plans. Fcap 8vo., cloth, Ios. $6 d$. net. Rs. 8.

KASHMIR AND JUMMU, ROUTES IN. A Tabulated Description of over Eighty Routes, showing Distance, Marches, Natural Characteristics, Altitudes, Nature of Supplies, Transport, etc. By MajorGeneral Marquis De Bourbel. Royal 8vo, cloth, $7 s$. $6 d$. net. Rs. 6.

KASHMIR EN FAMILLE, A Narrative of the Experiences of a Lady with Children; with useful Hints as to how the Journey may be comfortably made. By M. C. B. With a Preface by Major E. A. BURrows. 12 mo., cloth, 3 s. net. Rs. 2.

KASHMIR.-THACKER'S MAP OF JUMMOO AND KASHMIR. Prepared to Illustrate Duke's Kashmir Handbook. I6 miles = I inch. On Sheet unmounted, Rs. 2. Mounted on Linen and folded in book form, $4 s .6 d$. net. Rs. 3 .

MASURI.-GUIDE TO MASURI, LANDAUR, DEHRA DUN AND THE HILLS NORTH OF DEHRA, including Routes to the Snows and other places of note; with chapter on Garhwal (Tehri), Hardwar, Rurki and Chakrata. By John Northam. Fcap. 8vo., cloth, $3 s .6 d$. net. Rs. 2.8 .

PINDARI GLACIER, TOUR TO THE. By Major ST. JoHN Gore. With Map. Crown 8vo., sewed, $4 s$. $6 d$. net. Rs. 3.

SIMLA.-GUIDE TO SIMLA AND ROUTES INTO THE INTERIOR. Based on Towelle's Handbook and Guide to Simla. Revised with Map of Station and Index to all Houses; also Map of Hill States. I2mo., cloth, 6s. net. Rs. 4.

SIMLA.-HILLS BEYOND SIMLA. Three Months' Tour from Simla, through Bussahir, Kunowar, and Spiti to Lahoul. ("In the Footsteps of the Few.") By Mrs. J. C. Murray-Aynsley. Crown 8vo., cloth, 4s. $6 d$. net. Rs. 3 .

SIMLA ILLUSTRATED. A Series of 2I Photographic Views of the Summer Capital of India. Oblong 4to., paper, 3 s. 6 . net. ; Rs. 2.8 ; cloth, 5s. net. Rs. 3.8.

SIMLA.-THACKER'S MAP OF SIMLA. 6 inches = 1 mile. Showing every house. Folded in Wrapper, Is. $6 d$. net. Re. I.

SIMLA TO SHIPKI IN CHINESE THIBET. An Itinerary of the Roads and various minor Routes, with a few Hints to Travellers, and Sketch Map. By Major W. F. Gordon-Forbes, Rifle Brigade. Fcap. 8vo., cloth, 3s. net. Rs. 2.

ITINerARIES.-Simla to Shipki, "Charling" Pass, "Saharan to Narkunda," Forest Road, Simla to the "Chor," Pooi to Dankar, Chini to Landour, and the "Shalle." 
Annual Subscription-21s. Rs, 12, or with foreign postage, Rs. 14. Single copies, Re. 1.4.

\title{
THE INDIAN MEDICAL GAZETTE.
}

A Monthly Record of Medicine, Surgery, Public Health, and Medical Nerus, Indian and European, with special attention to Diseases of Tropical Conntries.

\author{
Edited by W. J. BUCHANAN, B.A., M.B., D.Ph., \\ Major, I.M.S. \\ Associate Editors :
J. MAITLAND, M.D.,
W. K, HATCH, M.B., F.R.C.S., Lt.-Col, , I.M.S., Madras.
Lt.-Col., I.M.S., Bombay

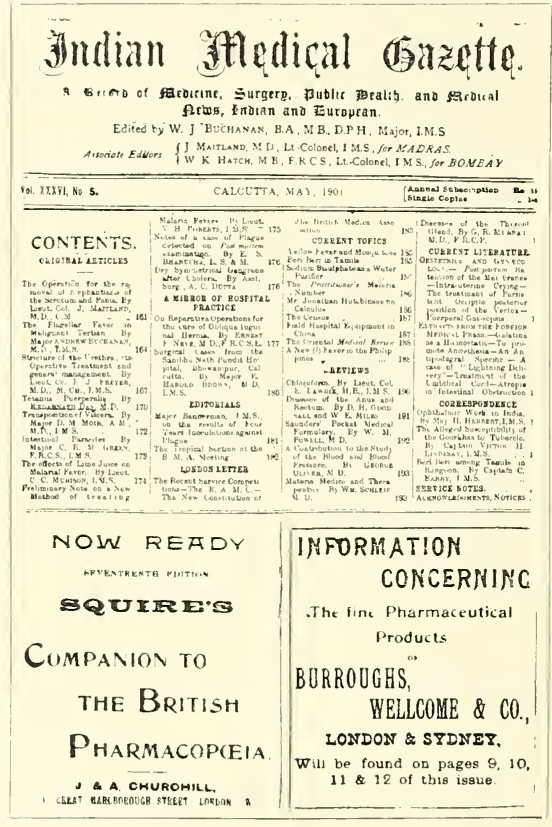

The "Indian Medical Gazette" was founded in 1865, and from its inception to the present date it has maintained its reputation as the LEADING INDIAN MEDICAL JOURNAL. The conduct of the Gazette is entrusted to officers of the Indian Medical Service, and, as a mirror reflecting the progress of Tropical Medicine and Surgery ; and a record of individual research, it is probably unique. The Gazette covers altogether different ground from the Lancet or the British Medical Journal and in no way competes with them for general information, although it chronicles the most important items of European Medical Intelligence. 
Annual Subscription-21s. Rs. 16. Single copies, Re. 1.

\title{
THE EMPRESS.
}

\author{
Published Fortnightly.
}

A IHigh Class Illustrated Magazine, published and printed in Calcutta, being aevoted exclusively to Indian Topics: Social,

Political, Sporting, Dramatic, Erc.

\section{THE ONLY ILLUSTRATED PAPER IN INDIA.}

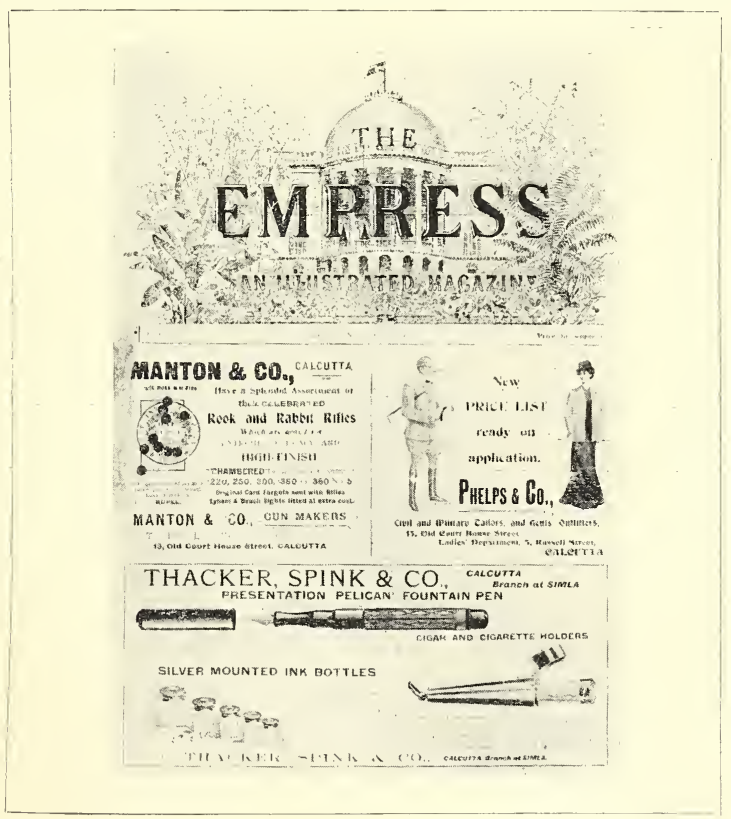

"The Empress" has a very wide and rapidly increasing circulation amongst the very highest class Residents, both European and Native, throughout the whole of India, the Far East and Ceylon. It has been in existence for many years, although the present improved style has only recently been adopted, and it is now undoubtedly very far in advance of any Magazine of its class published in India. 
In thick royal 8 vo., half leather, 2 roo pp., 36 s. net. Rs. 25.

\section{THACKER'S INDIAN DIRECTORY.}

Official, Legal, Educational, Professional, and Commercial.

\section{BRITISH INDIA and BURMA, and the NATIVE STATES of INDIA,}

WITH COMPLETE AND DETAILED INFORMATION OF THE CITIES OF

\section{CALCUTTA, MADRAS, BOMBAY, ALLAHABAD, LAHORE, SIMLA, AND RANGOON, \&c.}

Almanac and General Information, Holidays, \&c., Household Tables, Stamp Duties, Customs Tariff, Tonnage Schedules; Post Offices in India, forming a Gazetteer; Orders of the Star of India, Indian Empire, \&c.; Warrant of Precedence, Table of Salutes, \&.c., \&c.

Detailed and Classified Lists of all Commercial and Trading Firms, Railways, Municipalities, Harbour Trusts, \&c.

Complete Army List.

Civil Service List for all India.

Railway Directory.

Newspaper and Periodical Directory.

Conveyance Directory.
Directory of the Chief Industries of India, with Five Special Maps.

List of Clubs in India.

Alphabetical List of Residents, European and Native.

A List of British and Foreign Manufacturers with their Indian Agents.

With Railway Map of India. Two large plans of Calcutta, with houses in principal streets numbered, and references to Offices and Public Buildings. Maps of Calcutta and Environs; Bombay and Environs ; Madras and Environs. Five Maps of the Products of India.

Royal 8vo., boards, 330 pp., 9s. net. Rs. 7.8 .

\section{THACKER'S DIRECTORY OF THE CHIEF INDUSTRIES OF INDIA.}

Tea, Indigo, Coffee Concerns, Cotton Mills, Jute Mills, Jute Presses, Colleries, Mines, Sugar Factories, Rice Mills, Flour Mills, Paper Mills, Dis= tilleries, Breweries, Carpet Manufactories, Dairies, Fruit Gardens, Saw Mills, \&c., \&c., with their Capital, Directors, Proprietors, Agents, Managers, Details of Acreage, Extent of Mills, Trade Marks, \&c., \&c.-including

\section{A SEPARATE DIRECTORY OF ESTATES IN CEYLON.}

Ccloured Map of TEA DISTRICTS of INDIA: Assam, Cachar, Sylhet, Darjeeling, the Dooars, Dehra, Kumaon, Hazaribagh, Chittagong, Nilgiris, Travancore, Ceylon. Five Coloured Maps of PRODUCTS of INDIA.Indigo, Coffee, Sugar, Wheat, Rice, Cotton, Jute, Coal, Iron, Oil, Distribution of principal Trees, Cultivated and Uncultivated Areas. 





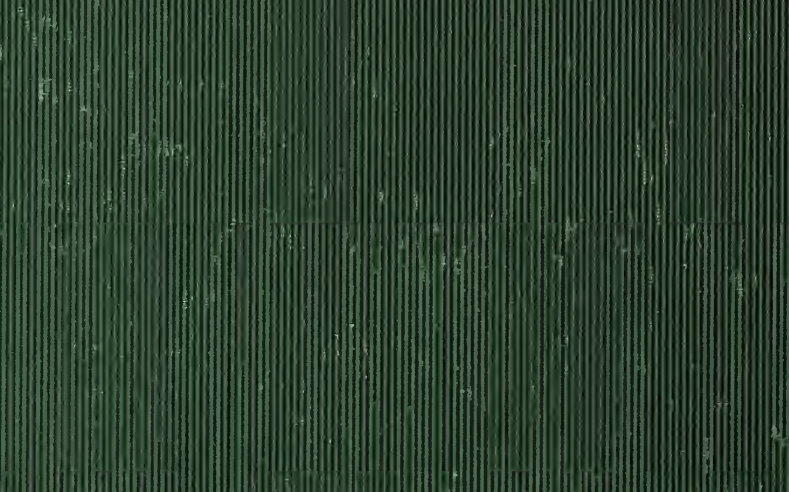

